\title{
EQCHANGE: A World Database on Actual and Equilibrium Effective Exchange Rates
}

Cécile Couharde, Anne-Laure Delatte, Carl Grekou,

Valérie Mignon \& Florian Morvillier

\section{Highlights}

- EQCHANGE is a global database of annual indicators on effective exchange rates.

- EQCHANGE includes two sub-databases providing information on: (i) nominal and real effective exchange rates, and (ii) equilibrium real effective exchange rates and corresponding currency misalignments for advanced, emerging and developing countries.

- The first sub-database provides effective exchange rates for 187 countries computed under three different weighting schemes and two panels of trading partners (186 and top 30) over the 1973-2016 period.

- The second sub-database provides behavioral equilibrium exchange rate (BEER) estimates and corresponding currency misalignments for 182 economies over the 1973-2016 period. 


\section{Abstract}

The aim of this paper is to present EQCHANGE, the new database developed by the CEPII on effective exchange rates. EQCHANGE includes two sub-databases containing data on (i) nominal and real effective exchange rates, and (ii) equilibrium real effective exchange rates and corresponding currency misalignments for advanced, emerging and developing countries. More specifically, the first sub-database delivers effective exchange rates for 187 countries that are computed under three different weighting schemes and two panels of trading partners (186 and top 30) over the 1973-2016 period. The second sub-database provides behavioral equilibrium exchange rate (BEER) estimates and corresponding currency misalignments for 182 economies over the 1973-2016 period. We describe the construction of the two datasets and illustrate some possible uses by presenting results concerning the evolution and main characteristics of currency misalignments in the world from 2015 to 2016. By providing publicly available indicators of equilibrium exchange rates, EQCHANGE aims to contribute to key debates in international macroeconomics.

\section{Keywords}

Exchange Rates, Equilibrium Exchange Rates, Currency Misalignments.

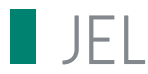

$\mathrm{F} 31, \mathrm{C} 23, \mathrm{C} 82$

\section{Working Paper}

\section{CEPI}

CEPII (Centre d'Etudes Prospectives et d'Informations Internationales) is a French institute dedicated to producing independent, policyoriented economic research helpful to understand the international economic environment and challenges in the areas of trade policy, competitiveness, macroeconomics, international finance and growth.
CEPII Working Paper

Contributing to research in international economics

C CEPII, PARIS, 2017

All rights reserved. Opinions expressed in this publication are those of the author(s) alone.

$\begin{array}{ll}\text { Editorial Director: } & \text { CEPII } \\ \text { Sébastien Jean } & \begin{array}{l}113, \text { rue de Grenelle } \\ 75007 \text { Paris }\end{array} \\ \text { Production: } & +33153685500 \\ \text { Laure Boivin } & \text { www.cepii.fr } \\ \text { No ISSN: } 1293-2574 & \text { Press contact: presse }\end{array}$




\title{
EQCHANGE: A World Database on Actual and Equilibrium Effective Exchange
}

Rates $^{1}$

\author{
Cécile Couharde*, Anne-Laure Delatte ${ }^{\dagger}$, Carl Grekou$^{\ddagger}$, Valérie Mignon ${ }^{\S}$ and Florian
}

Morvillier

\section{Introduction}

The widening and persistence of current account disequilibria at the international level -i.e., global imbalances - have refocused real exchange rate distortions at the core of international debates. What are the exchange rate adjustments needed to correct excessive imbalances? How to assess whether a currency is fundamentally misaligned, i.e. under- or over-valued? Due to the key role played by currency misalignments in economic research and policy analysis, several institutions publish various indicators that rely on more or less sophisticated measures.

To establish whether a currency is misaligned, and, if so, to which extent, a rough assessment can be obtained from the Big Mac index (BMI) developed since 1986 by The Economist. When compared to the actual exchange rate, this BMI gives an indication of the extent to which a currency is over- or undervalued according to the law of one price. $^{2}$ This measure is freely downloadable from the website of The Economist; ${ }^{3}$ but it only assesses the purchasing power between two countries in terms of a single good. Therefore, this indicator should not be interpreted systematically as indication of misalignment. This shortcoming is acknowledged by The Economist commenting that "the

\footnotetext{
${ }^{1}$ We are grateful to Philip Lane for kindly providing us with data on net foreign asset positions and to Sébastien Jean for helpful remarks and suggestions.

${ }^{*}$ EconomiX-CNRS, University of Paris Nanterre, France. Email: cecile.couharde@parisnanterre.fr. ${ }^{\dagger}$ CEPII, Griswold, CNRS and CEPR. Email: anne-laure.delatte@cepii.fr.

‡EconomiX-CNRS, University of Paris Nanterre and CEPII, France. Email: carl.grekou@cepii.fr.

$\S$ EconomiX-CNRS, University of Paris Nanterre and CEPII, France. Corresponding author: Valérie Mignon, EconomiX-CNRS, University of Paris Nanterre, 200 avenue de la République, 92001 Nanterre Cedex, France. Phone: 331409758 60. E-mail: valerie.mignon@parisnanterre.fr

IEconomiX-CNRS, University of Paris Nanterre and CEPII, France. Email: florian.morvillier@parisnanterre.fr.

${ }^{2}$ Put simply, if the Big Mac costs $\mathrm{x} \%$ more in a country $i$ than in a country $j$, then the currency of country $i$ will be $x \%$ overvalued relative to the currency of country $j$.

${ }^{3}$ http://www.economist.com/content/big-mac-index
} 
Big Mac index is merely a tool to make exchange-rate theory more digestible".

Several institutions have developed more sophisticated measures that differ from the BMI framework in various ways. First, these measures do not rely on a bilateral exchange rate as the $\mathrm{BMI}$, but on the real effective - i.e., multilateral - exchange rate (REER). Therefore, the misalignment of a currency is not measured against only one particular currency, but instead against an average index of a whole basket of currencies. Second, currency misalignments are calculated from the assessment of an equilibrium value of the REER, i.e. a value of the REER that is consistent with the macroeconomic balances (both internal and external) over the medium to the long term and given a set of fundamentals. The major advantage of this methodology over the simple BMI framework is that it allows the equilibrium value of the exchange rate to vary over time, reflecting changes in economic fundamentals. ${ }^{4}$

However, the lack of consensus on the definition of equilibrium exchange rates has made it very difficult to establish a unique approach (MacDonald, 2000; Driver and Westaway, 2004). Therefore, several equilibrium exchange rate methodologies exist and they are usually classified into three complementary groups: (1) the macroeconomic balance approach; (2) the behavioral equilibrium exchange rate (BEER) approach; and (3) the external sustainability approach. The macroeconomic balance approach calculates the difference between the current account (CA) projected over the medium term at prevailing exchange rates and an estimated equilibrium current account, or "CA norm". The BEER approach directly estimates an equilibrium real exchange rate for each country as a function of medium- to long-term fundamentals of the REER. The external sustainability approach calculates the difference between the actual current account balance and the balance that would stabilize the net foreign asset position of the country at some benchmark level.

Since the mid-1990s, the practice of the IMF, more precisely of the Consultative Group on Exchange Rate Issues (CGER), consists in using these three complementary approaches to provide exchange rate assessments for a number of advanced economies and emerging market countries (IMF, 2006). According to the IMF, using a broad range of indicators and other analytical tools provides the best possible estimate of the equilibrium exchange rate level. But, the information delivered by the IMF is not timely consistent, as it is

\footnotetext{
${ }^{4}$ The Economist has however improved the assessment of the BMI by introducing in 2011 an adjusted Big Mac index which controls for income per capita differential between countries.
} 
produced on an irregular basis, and it only concerns a limited sample of countries. ${ }^{5}$

Cline and Williamson (2008) have started a semi-annual estimate of fundamental equilibrium exchange rates (FEERs) for 35 countries, publicly available on the American Peterson Institute for International Economics (PIIE) website. ${ }^{6}$

The issue of currency misalignments has also been in the research agenda of the Centre d'Etudes Prospectives et d'Informations Internationales (CEPII), a French government funded research center focusing on the world economy. Since 2004, the CEPII has irregularly produced and published estimates of currency misalignments mainly based on the BEER approach, ${ }^{7}$ i.e. the second methodology employed by the IMF's CGER.

In sum, each aforementioned institute computes its own equilibrium real exchange rates (ERER), but there is no publicly available database providing these ERER and corresponding currency misalignments for a consistent and large sample of countries over a long period of time. In order to bridge the gap, the CEPII has developed a new database covering the largest sample of countries, the EQCHANGE database, from which (i) effective exchange rates and (ii) estimates of equilibrium real exchange rates and of currency misalignments can be freely downloaded.

The first sub-database, on effective exchange rates, provides indices of nominal and real effective exchange rates for 187 economies over the 1973-2016 period. The effective exchange rates indices are calculated for two panels of trade partners (186 and top 30) and using different weighting systems. Therefore, the EQCHANGE database brings a host of new features that greatly enhance the calculation of effective exchange rates - compared to existing annual databases - in terms of country/time coverage and methodological options (i.e., number of trade partners and weighting schemes).

\footnotetext{
${ }^{5}$ For example, IMF country reports do not necessarily include CGER assessments. Indeed, they can contain the findings of separate analyses, as IMF's working papers, central bank studies, and periodic reports of investment banks. In addition, the panel of considered countries varies across studies.

${ }^{6}$ While the FEER approach consists in ad hoc determination of current account norms, in the original macroeconomic balance approach these targets are obtained from the estimation of an equilibrium current account equation (see Williamson, 1994, and Cline, 2008, for details). Note further that the PIIE started publishing the data for a number of advanced countries and emerging economies in 2008. Access: https://piie.com/publications/policy-briefs/estimates-fundamental-equilibrium-exchangerates-november-2016

${ }^{7}$ The first working paper related to misalignments assessments was published in 2004 (Bénassy-Quéré et al., 2004). A recent publication reports estimates of currency misalignments within the euro area (Couharde et al., 2017; see also Coudert et al., 2013). For the sake of completeness, note that some CEPII studies have also provided misalignments based on the FEER approach, see e.g. Bénassy-Quéré et al. (2008) and Carton and Hervé (2013).
} 
The substantial enhancement introduced by EQCHANGE lays in the second sub-database which includes assessments of equilibrium real effective exchange rates and corresponding currency misalignments. More precisely, we estimate ERER based on the BEER approach (Clark and MacDonald, 1998). We have chosen this framework as it allows us to provide several ERER estimates for the vast majority of countries in the world (182 countries) and over a reasonably long time-span (from 1973 to 2016). Currency misalignments are then deduced from the difference between real effective exchange rates and their equilibrium values; we calculate various misalignments, depending on the definition of real effective exchange rates indices (weighting schemes differ for example), the specification of the equilibrium exchange rate model and the sample of countries.

By providing publicly available indicators of equilibrium exchange rates, our database helps documenting key debates such as the role of exchange rates on global and/or regional imbalances, the use of exchange rate as a mercantilist tool, the impact of currency misalignments on resources' reallocation between the tradable and the nontradable sectors and on economic growth, to name a few.

The primary objective of this paper is to provide a comprehensive account of our methodological framework to calculate its set of effective exchange rates and of equilibrium real exchange rates from which currency misalignments are derived. To this end, Section 2 is devoted to the presentation of the main features of the EQCHANGE database. As an illustration, Section 3 presents the evolution and essential characteristics of currency misalignments in the world from 2015 to 2016. Section 4 concludes the paper.

\section{The EQCHANGE database}

The EQCHANGE database developed by the CEPII consists of time series of:

- nominal and real effective exchange rates (Section 2.1);

- behavioral equilibrium exchanges rates and resulting currency misalignments (Section 2.2).

\subsection{The effective exchange rates dataset}

Several institutions, such as the World Bank (WB), the International Monetary Fund (IMF), the Bank of International Settlements (BIS), or think tanks such as Bruegel publish - more or less regularly — indexes of nominal and real effective exchange rates. The 


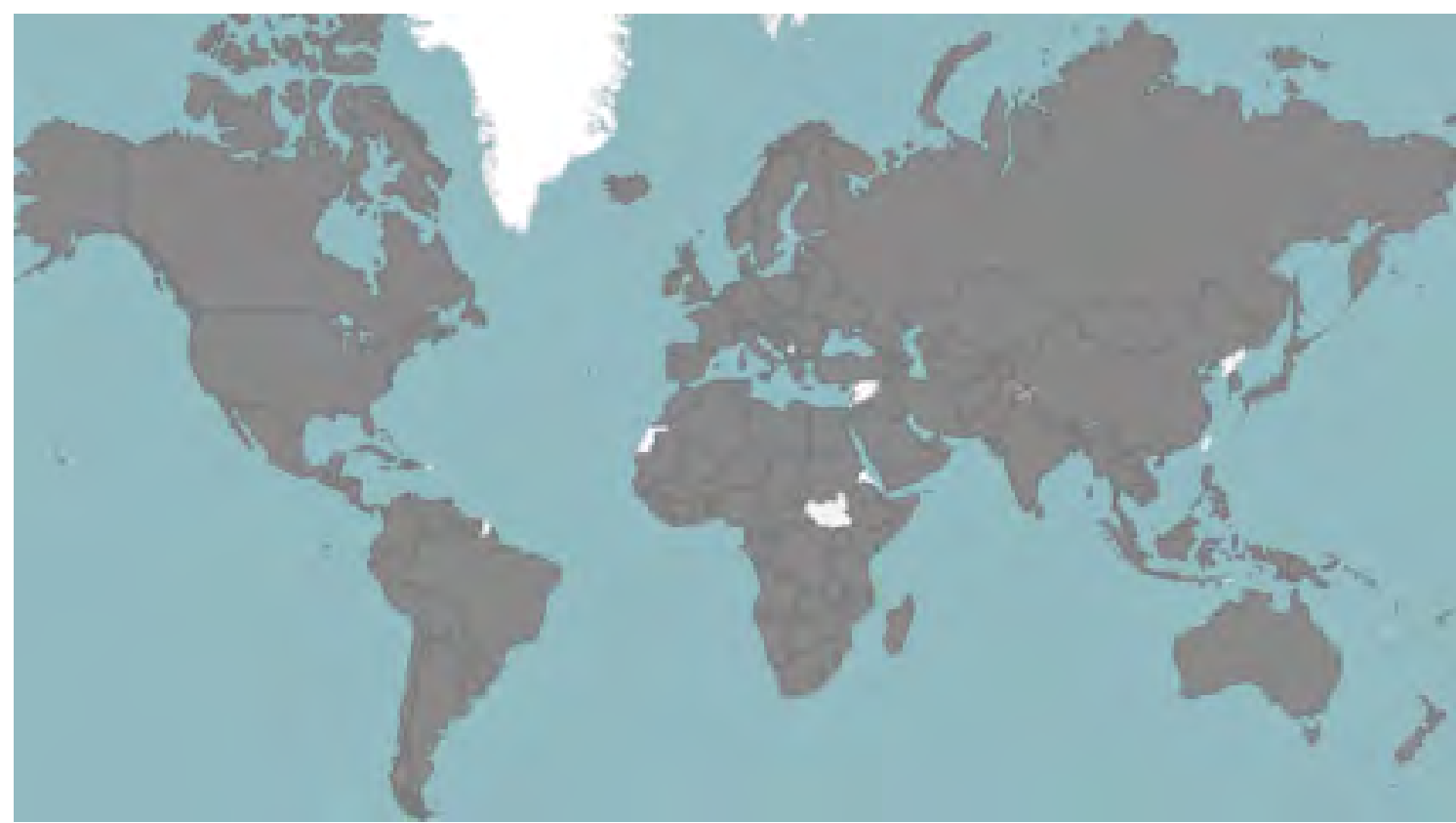

Figure 1 - Effective exchange rates dataset: country coverage

EQCHANGE database developed by the CEPII has two distinct characteristics when compared to those databases. First, the EQCHANGE database has the widest country/time coverage as we compute annual effective exchange rates (both in nominal and real terms) for 187 countries over the 1973-2016 period (see the list of countries in Appendix A.1, and Figure 1).

Second, by using a simple export weighting method, the EQCHANGE database includes effective exchange rates indices calculated and available along various dimensions, including the weighting scheme and trading partners' coverage. Therefore our database allows the adoption of alternate options for the selection of data. Firstly, effective exchange rates indices are available for two weighting schemes. The first one is time-invariant and consists in two weight sets respectively representative of foreign trade between $(i)$ 2008-2012, and (ii) 1973-2016. The second weighting system is time-varying and is essentially based on non-overlapping five-year average weights. ${ }^{8}$ Secondly, effective exchange rates rely on broad-based and narrow-based indices which are calculated against two main groups of trading partners, i.e. against 186 trading partners and the top 30 trading partners for each country. Differences between our database and other ones are reported in Table 1.

\footnotetext{
${ }^{8}$ The following periods - 1973-1979; 1980-1984; 1985-1989; 1990-1994; 1995-1999; 2000-2004; 20052009; 2010-2016 - have been considered.
} 
Table 1 - Comparison of various datasets

\begin{tabular}{|c|c|c|c|c|c|c|c|}
\hline \multirow{2}{*}{ Database } & \multicolumn{2}{|c|}{ Coverage } & \multicolumn{3}{|c|}{ Weighting system } & \multirow{2}{*}{ Data frequency } & \multirow{2}{*}{ Updates } \\
\hline & Countries & Period & Type & Period & Basket & & \\
\hline \multirow[t]{2}{*}{ CEPII } & 187 & 1973-2016 & (i) Fixed & $\left\{\begin{array}{l}1973-2016 \\
2008-2012\end{array}\right.$ & 186 and 30 & Annual & Regularly \\
\hline & & & (ii) Time-varying & 5-year window & & & \\
\hline & & & & & & Monthly, & \\
\hline IMF & 101 & $1962-2016$ & Fixed & 1991-2001 & 100 & $\begin{array}{c}\text { Quarterly and } \\
\text { Annual }\end{array}$ & Regularly \\
\hline WB & 109 & $1962-2016$ & Fixed & $1998-2003$ & 108 & Annual & Regularly \\
\hline \multicolumn{8}{|l|}{ Bruegel } \\
\hline (i) & 43 & $1970-2016$ & & & 41 & Monthly & \\
\hline (ii) & 153 & $1995-2016$ & Fived & $1000-2003$ & 138 & Monthly & Irrogularl \\
\hline (iii) & 74 & $1960-2016$ & rIxed & $1998-2003$ & 67 & Annual & irreguiarty \\
\hline (iv) & 178 & $1992-2016$ & & & 172 & Annual & \\
\hline Eurostat & 37 & 1994-2016 & Time varying & 1-year window & 36 & Annual & Regularly \\
\hline \multicolumn{8}{|l|}{ BIS } \\
\hline (i) & 27 & 1964-2016 & & & 26 & Monthly & \\
\hline (ii) & 61 & 1994-2016 & & & 60 & Monthly & \\
\hline (iii) & 27 & 1983-2016 & FIxed & $2011-2013$ & 26 & Annual & Regularly \\
\hline (iv) & 61 & $1980-2016$ & & & 60 & Annual & \\
\hline
\end{tabular}

Notes: the column "Basket" indicates the number of trade partners used to calculate the weights. 


\subsubsection{Methodological features}

An effective exchange rate measures the rate at which a country's currency exchanges against a basket of other currencies, in either nominal or real terms.

The nominal effective exchange rate of country $i$ in period $t\left(N E E R_{i, t}\right)$ measures the value of the currency of country $i$ against a weighted average of foreign currencies:

$$
N E E R_{i, t}=\prod_{j=1}^{N} N E R_{i j, t}^{w_{i j, t}}
$$

where $N E R_{i j, t}$ is the index of the nominal bilateral exchange rate between the currency of country $i$ and the currency of its trade partners $j$ in period $t,{ }^{9} N$ denotes the number of trading partners and $w_{i j, t}$ is the trade-based weight associated to the partner $j .{ }^{10}$

The real effective exchange rate of country $i$ in period $t\left(R E E R_{i, t}\right)$ is calculated as the weighted average of real bilateral exchange rates against each of its $N$ trading partners j:

$$
R E E R_{i, t}=\prod_{j=1}^{N} R E R_{i j, t}^{w_{i j, t}}
$$

where $R E R_{i j, t}=\frac{N E R_{i j, t} \times P_{i, t}}{P_{j, t}}$ is an index of the real exchange rate of the currency of the country $i$ vis-à-vis the currency of the trading partner $j$ in period $t . P_{i, t}$ and $P_{j, t}$ stand respectively for the price index of country $i$ and of country $j$.

With these definitions, a real (nominal) appreciation of the domestic currency is recorded as an increase in the real (nominal) effective exchange rate index.

Constructing an effective exchange rate index (both in nominal and real terms) for a given country then requires determining the trade-weight associated to each of its partners. In many circumstances, the exchange rate plays the role of a relative price of traded goods; hence, the relevant weights usually involve trade weights. Moreover, in most open economies, policy-makers are more interested in the total international competitive position of their country. In this case, appropriate effective exchange rate measures should include both import and export weights. Computing import weights is fairly straight-

\footnotetext{
${ }^{9}$ The nominal exchange rate is expressed as the number of foreign currency units per domestic currency. An increase therefore corresponds to an appreciation of the domestic currency against the foreign currency. ${ }^{10}$ These weights are normalized so that their sum is equal to one, i.e. $\sum_{j=1}^{N} w_{i j, t}=1$.
} 
forward: import weights are based on bilateral imports, i.e. on the relative importance of each of the partner countries, $j$, in total imports of a country $i$. Turning to export weights, various procedures exist including bilateral and double export weighting schemes. We prefer here to follow the bilateral-based approach for its simplicity and transparency properties. Indeed, this procedure is based on bilateral exports and therefore takes into account only competition between the domestic country and its direct trading partners. In doing this, we have chosen not to consider the possible indirect competition on the third markets based on the calculation of a double export weight. Specifically, international institutions such as the IMF, the WB and the BIS construct their real effective exchange rate series attempting to capture third market effects. Compared to our simple weighting procedure, the double export weights method contains additional information on the competition faced by country i's exporters in each given foreign market from exporters of the countries included in the group of the $N$ trading partners. ${ }^{11}$ However, while delivering a more rigorous assessment of the export competition in foreign markets, this weighting scheme can lead to a smaller area and time coverage and provides less flexibility in updating the dataset, because of limitations in data availability. In particular, the inclusion of the gross value of the domestically produced supply of manufactured goods in the calculation of the double export weight tends to restrict the number of countries that can be considered. In addition, if we compare our calculated overall weights (see paragraph below) to those of the IMF, we do not observe any significant differences. We therefore conclude that our simpler approach is broadly equivalent to that of the IMF when considering the overall weights. All these reasons justify our choice to not replicate the double export weighting scheme.

The overall weight of each partner $j$ in the trade of country $i$ at period $t\left(w_{i j, t}\right)$ is obtained as the weighted average of the export and import weights:

$$
W_{i j, t}=\left(\frac{M_{i, t}}{M_{i, t}+X_{i, t}}\right) \times W_{i j, t}^{I m p}+\left(\frac{X_{i, t}}{M_{i, t}+X_{i, t}}\right) \times W_{i j, t}^{E \times p}
$$

where $W_{i j, t}^{I m p}$ and $W_{i j, t}^{E x p}$ are partner country $j$ 's import and export weights, respectively and $M_{i, t}$ and $X_{i, t}$ are total imports and total exports of country $i$.

\footnotetext{
${ }^{11}$ Indeed, under this approach, the export weight for any country is derived as a combination of two components: a bilateral export weight, which accounts for direct competition between exporters and domestic producers in a particular export market; and a third-market export weight, which captures competition between exporters from two different countries in a third market. The methodology is detailed in Turner and Van't dack (1993).
} 
The import and export weights (Equations (4) and (5)) of each partner $j$ are calculated as its simple share of country i's imports and exports:

$$
\begin{aligned}
& W_{i j, t}^{I m p}=M_{i, t}^{j} / M_{i, t} \\
& W_{i j, t}^{E x p}=X_{i, t}^{j} / X_{i, t}
\end{aligned}
$$

where $M_{i, t}^{j}$ denotes import flows into the country $i$ from country $j$ during period $t$, and $X_{i, t}^{j}$ denotes export flows of country $i$ to market $j$ during period $t$.

\subsubsection{Data}

Effective exchange rates are computed from the bilateral exchange rate with the US dollar of each country. The primary data source for bilateral exchange rates is the World Bank's World Development Indicators (WDI). Other alternative sources such as national central bank statistics or the Penn World tables $(9.0)^{12}$ have also been used in the case of incomplete data (see Table A.2.1 in Appendix A.2).

The price series used to deflate the bilateral nominal exchange rates are the most commonly used price series, i.e. Consumer Price Index (CPI). Although there are theoretical reasons to prefer other types of price indexes when measuring competitiveness (Rosensweig, 1987), CPls have the advantage of being timely and available for a wide array of countries over a long time period (see Table A.2.2 in Appendix A.2).

\subsubsection{Empirical comparisons for robustness checks}

As effective exchange rates can be calculated by using different weighting schemes, we report the correlations between the nominal (resp. real) effective exchange rates of our database and those provided by other databases in Table A.3.1 (resp. A.3.2) in Appendix A.3. Table A.3.1 shows that in most cases, there is a strong correlation between the different databases' nominal effective exchange rates (NEERs). In contrast, the correlations for real effective exchange rates (REERs) are weaker but, compared to the Bruegel's REERs, the CEPII's REERs present higher correlations with those provided by the IMF and the WB (Table A.3.2). However, the statistical reliability of those

12PWT 9.0 can be downloaded via the University of Groningen webpage at http://www.rug.nl/ggdc/productivity/pwt/ 
correlations is limited, due to the relatively small number of common observations. In order to get a proper/meaningful comparison of the different series and for illustrative purposes, we have reported in Figures $C .1$ and $C .2$ in Appendix $C$ the evolution of the NEERs and REERs provided by the different datasets. As shown, we validate our calculations as the dynamics of our exchange rates indices quite follow those issued from the different databases.

\subsection{The database on equilibrium real exchange rates and currency misalignments}

In this section we outline the construction of this second database and also discuss the underlying methodology and data sources. The dataset computes equilibrium real effective exchange rates and currency misalignments from 1973 to 2016, for 182 economies, i.e. the largest coverage with available data (Figure 2 ). ${ }^{13}$

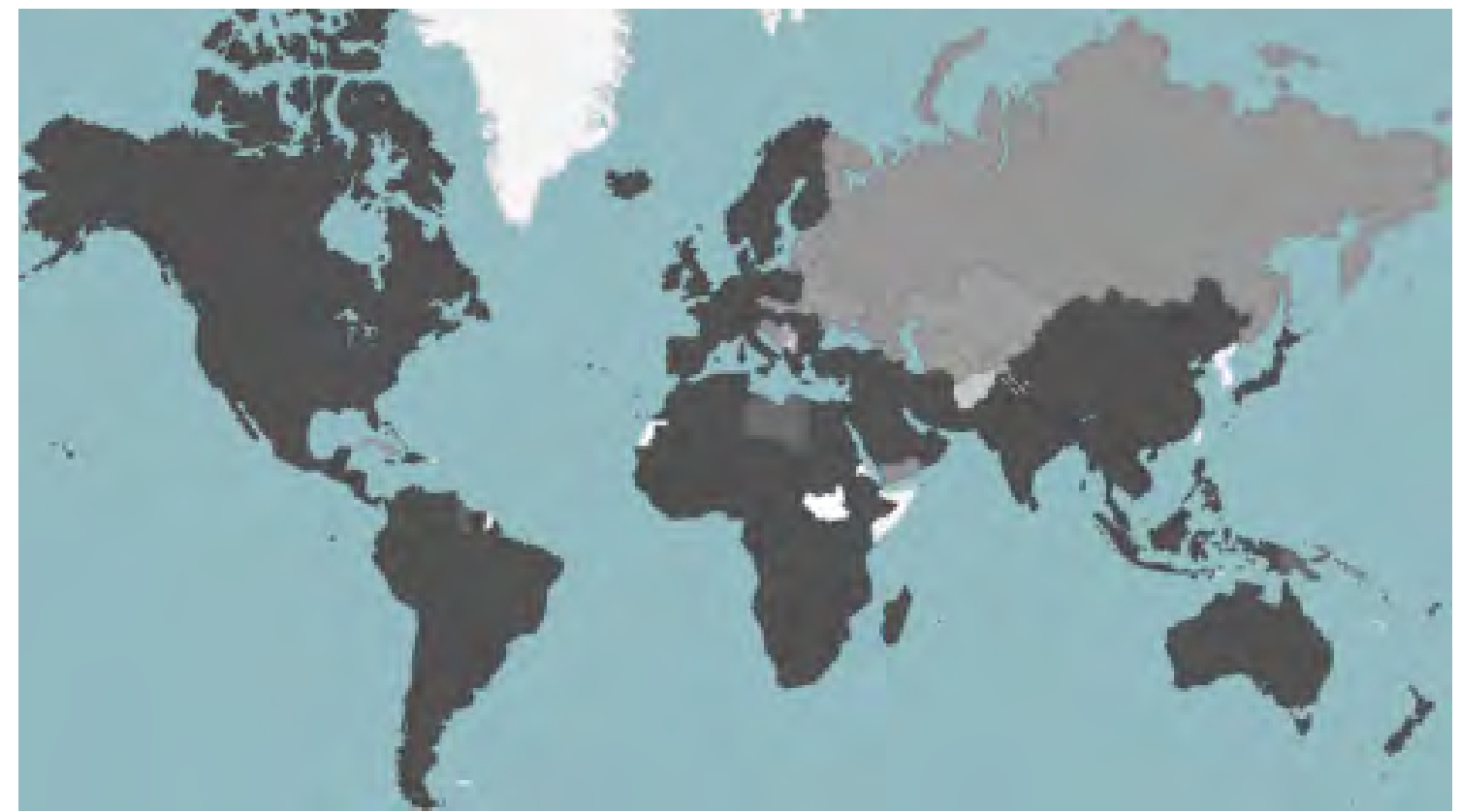

Figure 2 - The equilibrium real exchange rates dataset: country coverage

Note: the different shades of grey indicate the temporal coverage of the series: the darker, the longer is the temporal coverage.

This database has three distinct characteristics. First, it is the first database on equilibrium real effective exchange rates and currency misalignments with a global coverage. Second, we rely on the BEER approach rather than the purchasing power parity (PPP) approach. Our measures are then less restrictive than those derived from the PPP only (as the Big Mac Index for example). Moreover, BEER estimates are a good alternative to

${ }^{13}$ For few economies such as countries of the former Soviet Union, series of equilibrium exchange rates start later, due to data availability. 
FEER assessments — such as those provided by the Peterson Institute for International Economics - as the underpinning methodology $(i)$ does not require assumptions about the internal and external balances, and (ii) takes into account stock effects through the net foreign asset position. Third, we compute various series of equilibrium exchange rates and currency misalignments along a large set of assumptions used for the equilibrium exchange rate model, for the measure of REER, and for the coverage of partners' countries.

\subsubsection{Equilibrium exchange rates}

The BEER approach. We rely on the BEER approach to assess equilibrium real exchange rates (see Clark and MacDonald, 1998). Indeed, one of the difficulties when computing equilibrium exchange rates is to identify the long-run equilibrium path of the economy. We have opted for the BEER approach which is more pragmatic, as it does not require to estimate or to make assumptions on the long-run values of the economic fundamentals (such as current account norms for instance) as in the macroeconomic balance approach. ${ }^{14}$ Instead, the BEER approach consists in assessing directly the equilibrium level of real exchange rates through the estimation of a long-run relationship between real exchange rates and their fundamentals. This approach is then relatively simple and easy to implement and requires few data. This point is crucial given the paucity of reliable data in several developing and emerging economies.

Analyses differ in the choice of real exchange rates' fundamentals, in part because of countries' sample considerations. Edwards (1988), Elbadawi (1994), Hinkle and Montiel (1999) and Elbadawi and Soto (2008) —among others - have provided suitable theoretical frameworks that identify potential drivers of real exchange rates in developing and emerging countries. In particular, the major fundamentals behind long-run movements of the real exchange rate identified for these countries are usually the terms of trade, the relative productivity of the tradable sector and the net foreign asset position, as we will detail below. ${ }^{15}$ For the advanced economies, Faruqee (1995), followed by Alberola et al.

\footnotetext{
${ }^{14}$ We do not postulate that the BEER methodology achieves superior performance against other equilibrium exchange rate approaches. Indeed, all these approaches, far from being opposed to each other, are rather complementary insofar as they assess equilibrium exchange rates over different time horizons (BénassyQuéré et al., 2010).

${ }^{15}$ For the sake of completeness and as a robustness check, we have also included in our analysis other variables considered to be of importance to the exchange rate determination for developing countries such as government spending, remittances, financial development, aid flows, and openness. However, employing such variables dramatically reduce the size of the sample (both in terms of temporal and individual dimensions). Furthermore, the inclusion of these additional variables did not change the results
} 
(1999) and Alberola (2003), have proposed a stock-flow model for the exchange rate determination in the long run, based on the balance-of-payments approach which emphasizes the accumulation of external disequilibria and the Balassa-Samuelson hypothesis which underscores relative productivity trends (Balassa, 1964; Samuelson, 1964).

The empirical framework. In line with this literature, the three following variables are included in our regressions as fundamentals of the real exchange rate: (i) a measure of sectoral productivity relative to trading partners - to account for the Balassa-Samuelson effect, (ii) the economy's net foreign asset position, and (iii) the economy's terms of trade.

However, rather than pooling directly together — in the same equation - these three fundamentals, we adopt a sequential approach by starting with the most parsimonious regression model including only one variable and then by adding successively the other fundamentals in the regression model. Then, the first model (Model 1) we consider includes only a measure of relative productivity and is drawn on the findings that the Balassa-Samuelson effect (BS, thereafter) is the most important economic force shaping real exchange rate behavior. Equilibrium exchange rates derived from this first model can be interpreted as PPP-based equilibrium exchange rates adjusted by the BS effect. We also estimate two additional models which augment Model 1 by adding ( $i$ ) the net foreign asset position (Model 2), and (ii) the net foreign position and the terms of trade (Model 3):

$$
\begin{gathered}
\text { reer }_{i, t}=\mu_{i}+\beta B S_{i, t}+\varepsilon_{i, t} \\
\text { reer }_{i, t}=\mu_{i}+\beta_{1} B S_{i, t}+\beta_{2} n f a_{i, t}+\varepsilon_{i, t} \\
\text { reer }_{i, t}=\mu_{i}+\beta_{1} B S_{i, t}+\beta_{2} n f a_{i, t}+\beta_{3} \text { tot }_{i, t}+\varepsilon_{i, t}
\end{gathered}
$$

where reer $_{i, t}$ denotes the real effective exchange rate expressed in logarithm; $B S_{i, t}$, $n f a_{i, t}$ and tot $_{i, t}$ stand respectively for the BS effect proxy (expressed in logarithm), the net foreign asset position (in percentage of GDP) and the terms of trade (expressed in logarithm). $\mu_{i}$ represents country-fixed effects and $\varepsilon_{i, t}$ is an independent and identically distributed error term.

in any substantial way. The results are available upon request. 
The improvement of these three fundamentals is expected to appreciate the equilibrium real exchange rate. First, the Balassa-Samuelson effect describes the convergence process of an economy which results in an appreciation of its real exchange rate through a larger productivity growth in the domestic traded goods. ${ }^{16}$ If the real appreciation is in line with the stage of development, the currency of the country will then not necessarily be overvalued.

Second, the connection between real exchange rates and net foreign assets derives from the intertemporal budget constraint which links external assets, real exchange rate and trade balance together, documented by Lane and Milesi-Ferretti (2002). When a country runs a current account deficit, it is building up liabilities to the rest of the world. Solvency requires that the country be willing and able to (eventually) generate sufficient current account surpluses to repay what it has borrowed to finance the current account deficits. Therefore, a country running a current account deficit (borrowing more) may have an overvalued currency: indeed, it should register a more depreciated real exchange rate in order to restore external equilibrium. Conversely, net creditor countries may have an undervalued currency and experience real exchange rate appreciations: their trade deficit will be indeed offset by investment income on their net foreign asset position.

Finally, the impact of changes in the terms of trade on the equilibrium real exchange rate is theoretically ambiguous. On the one hand, an improvement of the terms of trade (an increase in the relative price of exports to imports) leads to a substitution effect. Domestic agents shift their demand towards imported goods and, as a result, the domestic currency will be overvalued: it will have to depreciate to restore the external equilibrium. On the other hand, an income effect due to the improved current account may generate higher demand for non-traded goods. Consequently, prices in the nontraded goods sector tend to rise as well as the general price level, leading in turn to an appreciation of the equilibrium real exchange rate. Empirically, it has been documented that the negative substitution effect of change in terms of trade is not large enough to outweigh the income effect. This is so because imports and domestic goods are imperfect substitutes. It follows therefore that the net result of an increase in the relative price of exports to imports will be an appreciation of the equilibrium real exchange rate (De

\footnotetext{
${ }^{16}$ According to the Balassa-Samuelson effect, a relatively larger productivity growth in the domestic traded goods compared to the non-traded goods sector causes wage increases in the tradable goods sector. Equalization in wages across sectors leads to an increase in wages also in the non-traded goods sector. Consequently, prices in the non-traded goods sector tend to rise as well as the general price level, leading therefore to an appreciation of the real exchange rate.
} 
Gregorio and Wolf, 1994).

We estimate these three equilibrium real exchange rate models in a panel data setting. To tackle the issue of heterogeneity, these relationships are also estimated for different subsamples: sub-samples of countries classified according to their level of development (i.e. advanced economies, emerging markets, and developing countries), sub-samples based on geographical considerations and sub-samples of countries belonging to a currency block (such as the European Monetary Union). We also rely on the Pooled Mean Group (PMG) estimator (Pesaran et al., 1999) which permits a greater degree of heterogeneity - compared to the Fully-Modified OLS and Dynamic OLS procedures - by allowing short-run coefficients and error variances to differ across groups. ${ }^{17}$ Equilibrium real exchange rates (ERERs) are derived from the fitted value of real effective exchange rates given by the estimated equilibrium relationship.

Data. Empirical studies often test the BS hypothesis by relating the real exchange rate to the income per capita (PPP real GDP per capita) differential rather than to the productivity differential. The reason for this is that sectoral data on output and employment for traded and non-traded goods sectors are not available for all countries. We adopt the same approach to proxy the BS effect. Our relative productivity measure is therefore proxied here by the ratio between the real GDP per capita (PPP terms) in the considered country and the trade weighted average of the PPP real GDP per capita of the trade partners. The weights and trade partners are the same as those used for the calculation of the effective exchange rates. Hence, for each weighting schemes, we have a consistent measure of the BS effect. Data on PPP real GDP per capita are collected from the Penn World tables 9.0. We update these data and extend them to a larger set of countries by using the WDI and the World Economic Outlook databases (WEO, IMF; see Table A.2.3 in Appendix A.2). The net foreign asset positions are extracted from the Lane and Milesi-Ferretti (2007) database (extended to 2014) and updated using information on national current accounts (WEO). Finally, the terms of trade series are taken from the WDI database. The series are also updated using different secondary sources (see Table A.2.4 in Appendix A.2 for further details).

${ }^{17}$ The long-run homogeneity restriction of slopes can be tested by performing a Hausman (1978)-type test, which compares the long-run coefficients of the MG and PMG estimators. 
Benchmark specification results. As an illustration, we present here some of our regression results. ${ }^{18}$ Table 2 reports the estimated coefficients from our benchmark specifications, based on the whole sample of countries and broad REER indexes. The estimated coefficients correspond to the estimates of the $\beta$ coefficients in models 1,2 and 3 for the alternative weighting schemes used to calculate real effective exchange rates.

As discussed above, economic theory predicts positive coefficients for the three fundamentals of the real exchange rate that we have considered. From Table 2 it is clear that the coefficients for the GDP per capita, net foreign assets and the terms of trade have the expected positive sign and are significant for all or at least for the great majority of model specifications.

However as the coefficients are estimated in a panel setting, they also depend on the sample of countries over which the model is estimated. To illustrate this we report in Table 3 the $\beta$ coefficients estimated under the same baseline specification as before on sub-samples of countries according their level of development. The three fundamentals exhibit a statistically significant relationship with real exchange rates for the developing countries: the coefficients are significant and have the expected sign. For emerging and advanced economies, the coefficient for GDP per capita is either not significant or has not the expected positive sign, especially for model $3 .{ }^{19}$

These findings illustrate that the estimates depend on the countries considered in the sample, the combination of explanatory variables included in the model and the particular methodological approach being used to assess REER. For this reason, the EQCHANGE database offers several different options in the estimation procedure. ${ }^{20}$ This allows users to get a potential range of equilibrium exchange rates' assessments for a particular country and an idea of margins of uncertainty that are inherent to this type of estimations.

\footnotetext{
${ }^{18}$ For the sake of brevity, we do not report all regression estimations. Appendix B shows all the results of the econometric estimations of models 1,2 and 3 , including narrow REER indexes and other sub-samples of countries.

${ }^{19}$ As suggested by De Gregorio and Wolf (1994), the fact that the relative income variable becomes insignificant when adding the terms of trade variable means that it may play a proxy role for terms of trade shocks in models when the latter are ignored. Indeed, the GDP per capita allows for additional demand side effects, arising, for example, from non-homothetic preferences linking demand shares and hence the real exchange rate to the level of income. Therefore, it can be reasonably expected that the GDP per capita also captures the income effect caused by the terms of trade.

${ }^{20}$ The choice among these options will depend not only on the context but also on the research objective.
} 


\subsubsection{Derivation of currency misalignments time series}

The last step consists in combining series of real effective exchange rates with series of equilibrium exchange rates to derive currency misalignments for each country. Basically, we calculate, for each country $i$, the difference between the observed real effective exchange rate $\left(\right.$ reer $\left._{i, t}\right)$ and its equilibrium level $\left(\right.$ erer $\left._{i, t}\right)$ at date $t$ :

$$
\text { Mis }_{i, t}=\text { reer }_{i, t}-\text { erer }_{i, t}
$$

Misalignments' values then give the magnitude of the real exchange rate adjustment that would restore equilibrium. Given the definition of the real effective exchange rate, a negative sign of the misalignment (i.e., reer $_{i, t}<$ erer $_{i, t}$ ) indicates an undervaluation (the real exchange rate must appreciate to converge towards its long-run equilibrium value), whereas a positive sign (i.e., reer $_{i, t}>$ erer $_{i, t}$ ) indicates an overvaluation of the real effective exchange rate (the real exchange rate must depreciate to converge towards its long-run equilibrium value).

By construction, currency misalignments from the BEER approach imply that each country has a REER in equilibrium on average over the estimation period. This assumption can be considered as plausible, given the length of the estimation period. Fundamentals' and REERs' variations then allow the REER deviating from this average value with alternating periods of undervaluation and overvaluation. Indeed, as shown in Equation (6), currency misalignments can be explained by a change in REERs and/or a change in ERERs. By providing these two series, the EQCHANGE database allows users to identify exactly the roots of currency misalignments in a particular country. Furthermore, it also allows alternate currency misalignments' indicators depending on the selection of the specific equilibrium relationship estimated (model 1, 2 or 3 ), of the countries' sample (whole sample or sub-samples depending on the level of development, geographical or exchange rate regime considerations) used in the regressions and of the real effective exchange rate index (narrow or broad). ${ }^{21}$ The availability of different currency misalignments' indicators gives then some idea on the robustness of our estimates, but also allows any researcher using these estimates to perform robustness checks.

\footnotetext{
${ }^{21}$ Due to these different options, 18 possible estimates of ERER are then available for each country (2 REER indexes $\times 3$ ERER models $\times 3$ countries' samples).
} 
Table 2 - Equilibrium exchange rate model estimations (all countries, 186 trade partners)

\begin{tabular}{|c|c|c|c|c|c|c|c|c|c|}
\hline \multirow{3}{*}{\begin{tabular}{|c|}
$\begin{array}{c}\text { Weighting } \\
\text { system }\end{array}$ \\
Model
\end{tabular}} & \multicolumn{6}{|c|}{ Fixed } & \multirow{2}{*}{\multicolumn{3}{|c|}{$\begin{array}{c}\text { Time-varying weights } \\
\text { (5-year averages) }\end{array}$}} \\
\hline & \multicolumn{3}{|c|}{ (1973-2016) } & \multicolumn{3}{|c|}{$(2008-2012)$} & & & \\
\hline & (1) & $(2)$ & (3) & (1) & $(2)$ & (3) & (1) & $(2)$ & (3) \\
\hline$B S$ & $0.327 * * *$ & $0.431 * * *$ & $0.0771^{* * *}$ & $0.276^{* * *}$ & $0.249 * * *$ & -0.0238 & $0.368 * * *$ & $0.409 * * *$ & $0.0740 * * *$ \\
\hline & $(0.0222)$ & $(0.0268)$ & $(0.0227)$ & $(0.0204)$ & $(0.0229)$ & $(0.0210)$ & $(0.0215)$ & $(0.0218)$ & $(0.0209)$ \\
\hline$N F A$ & & $0.166 * * *$ & $0.0466 * * *$ & & $0.177^{* * *}$ & $0.0431 * * *$ & & $0.163 * * *$ & $0.0432 * * *$ \\
\hline & & $(0.0145)$ & $(0.00616)$ & & $(0.0135)$ & $(0.00580)$ & & $(0.0150)$ & $(0.00569)$ \\
\hline TOT & & & $0.402 * * *$ & & & $0.480 * * *$ & & & $0.419 * * *$ \\
\hline & & & $(0.0309)$ & & & $(0.0308)$ & & & $(0.0307)$ \\
\hline
\end{tabular}

Table 3 - Equilibrium exchange rate model estimations (sub-samples of countries, 186 trade partners)

\begin{tabular}{|c|c|c|c|c|c|c|c|c|c|}
\hline \multirow{3}{*}{ 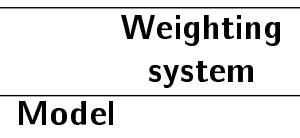 } & \multicolumn{6}{|c|}{ Fixed } & \multirow{2}{*}{\multicolumn{3}{|c|}{$\begin{array}{c}\text { Time-varying weights } \\
\text { (5-year averages) }\end{array}$}} \\
\hline & \multicolumn{3}{|c|}{$(1973-2016)$} & \multicolumn{3}{|c|}{$(2008-2012)$} & & & \\
\hline & (1) & (2) & (3) & (1) & $(2)$ & (3) & (1) & $(2)$ & (3) \\
\hline \multicolumn{10}{|c|}{ Advanced economies } \\
\hline$B S$ & $\begin{array}{l}0.0911^{*} \\
(0.0486)\end{array}$ & $\begin{array}{l}-0.0490 \\
(0.0365)\end{array}$ & $\begin{array}{c}-0.0639 * * \\
(0.0313)\end{array}$ & $\begin{array}{l}-0.0127 \\
(0.0363)\end{array}$ & $\begin{array}{c}-0.173^{* * *} \\
(0.0295)\end{array}$ & $\begin{array}{c}-0.0801 * * * \\
(0.0242)\end{array}$ & $\begin{array}{c}0.605 * * * \\
(0.115)\end{array}$ & $\begin{array}{c}-0.299 * * * \\
(0.0553)\end{array}$ & $\begin{array}{c}0.0481 \\
(0.0526)\end{array}$ \\
\hline$N F A$ & & $\begin{array}{l}0.0469 * * * \\
(0.00739)\end{array}$ & $\begin{array}{c}0.0159 * \\
(0.00944)\end{array}$ & & $\begin{array}{l}0.0589 * * * \\
(0.00916)\end{array}$ & $\begin{array}{r}0.0266 * * \\
(0.0110)\end{array}$ & & $\begin{array}{l}-0.0211 \\
(0.0137)\end{array}$ & $\begin{array}{c}0.0176^{*} \\
(0.00978)\end{array}$ \\
\hline TOT & & & $\begin{array}{l}1.028 * * * \\
(0.0785)\end{array}$ & & & $\begin{array}{l}0.833 * * * \\
(0.0923)\end{array}$ & & & $\begin{array}{l}1.018 * * * \\
(0.0747)\end{array}$ \\
\hline \multicolumn{10}{|c|}{ Emerging economies } \\
\hline$B S$ & $\begin{array}{c}0.380 * * * \\
(0.0403)\end{array}$ & $\begin{array}{c}0.735^{* * *} \\
(0.0440)\end{array}$ & $\begin{array}{l}-0.0438 \\
(0.0352)\end{array}$ & $\begin{array}{c}0.278 * * * \\
(0.0398)\end{array}$ & $\begin{array}{c}0.630 * * * \\
(0.0542)\end{array}$ & $\begin{array}{c}-0.0965^{* *} \\
(0.0379)\end{array}$ & $\begin{array}{c}0.336 * * * \\
(0.0354)\end{array}$ & $\begin{array}{c}0.478 * * * \\
(0.0325)\end{array}$ & $\begin{array}{l}-0.0184 \\
(0.0208)\end{array}$ \\
\hline$N F A$ & & $\begin{array}{c}0.183^{* * *} * \\
(0.0383)\end{array}$ & $\begin{array}{c}0.0111 \\
(0.0283)\end{array}$ & & $\begin{array}{c}0.150 * * * \\
(0.0339)\end{array}$ & $\begin{array}{c}0.0158 \\
(0.0264)\end{array}$ & & $\begin{array}{c}0.227^{* * *} * \\
(0.0358)\end{array}$ & $\begin{array}{c}0.132 * * * \\
(0.0236)\end{array}$ \\
\hline TOT & & & $\begin{array}{c}0.232^{* * *} \\
(0.0312)\end{array}$ & & & $\begin{array}{c}0.336 * * * \\
(0.0363)\end{array}$ & & & $\begin{array}{c}0.208 * * * \\
(0.0289)\end{array}$ \\
\hline \multicolumn{10}{|c|}{ Developing countries } \\
\hline$B S$ & $\begin{array}{l}0.390 * * * \\
(0.0288)\end{array}$ & $\begin{array}{l}0.258 * * * \\
(0.0310)\end{array}$ & $\begin{array}{c}0.727 * * * \\
(0.0343)\end{array}$ & $\begin{array}{l}0.327 * * * \\
(0.0252)\end{array}$ & $\begin{array}{l}0.154 * * * \\
(0.0262)\end{array}$ & $\begin{array}{l}0.244 * * * \\
(0.0297)\end{array}$ & $\begin{array}{l}0.406 * * * \\
(0.0285)\end{array}$ & $\begin{array}{l}0.102 * * * \\
(0.0141)\end{array}$ & $\begin{array}{l}0.226 * * * \\
(0.0232)\end{array}$ \\
\hline$N F A$ & & $\begin{array}{l}0.211 * * * \\
(0.0185)\end{array}$ & $\begin{array}{c}0.0910 * * * \\
(0.0132)\end{array}$ & & $\begin{array}{l}0.257 * * * \\
(0.0202)\end{array}$ & $\begin{array}{l}0.0456 * * * \\
(0.00802)\end{array}$ & & $\begin{array}{l}0.191 * * * \\
(0.0172)\end{array}$ & $\begin{array}{l}0.116 * * * \\
(0.00836)\end{array}$ \\
\hline TOT & & & $\begin{array}{c}0.113^{* * *} \\
(0.0419)\end{array}$ & & & $\begin{array}{c}0.266 * * * \\
(0.0334)\end{array}$ & & & $\begin{array}{c}-0.166 * * * \\
(0.0317)\end{array}$ \\
\hline
\end{tabular}




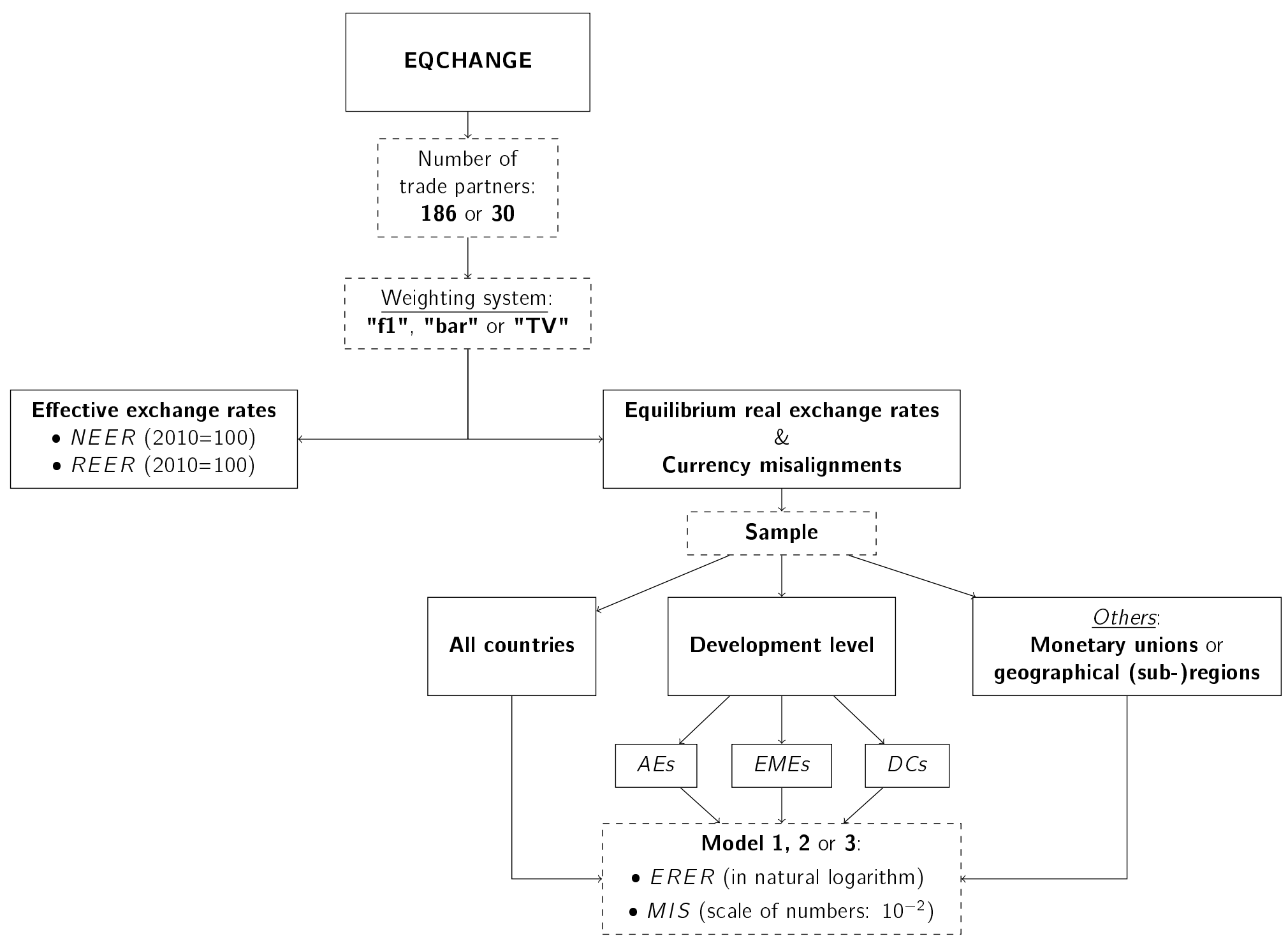

Figure 3 - Structure of EQCHANGE

Notes: Fixed weights based on the 2008-2012 (resp. 1973-2016) period are referred as "weights f1" (resp. "weights bar"). Similarly, time-varying weights are referred as "weights TV". The considered periods are: 1973-1979; 1980-1984; 1985-1989; 1990-1994; 1995-1999; 2000-2004; 2005-2009; 2010-2016. AEs: advanced economies; EMEs: emerging economies; DCs: developing countries. 


\subsection{How to use EQCHANGE}

EQCHANGE (http://www.cepii.fr/CEPII/fr/bdd_modele/presentation.asp?id=34) has the advantage to be an online web resource that provides simple and quick access to time series of nominal and real effective exchange rates (resp. NEER and REER), as well as equilibrium real exchange rates ( $E R E R$; in natural logarithm) and currency misalignments (MIS; scale of numbers: $10^{-2}$ ). ${ }^{22}$ The structure of EQCHANGE is presented in Figure 3.

\section{Currency misalignments in 2016: an overview}

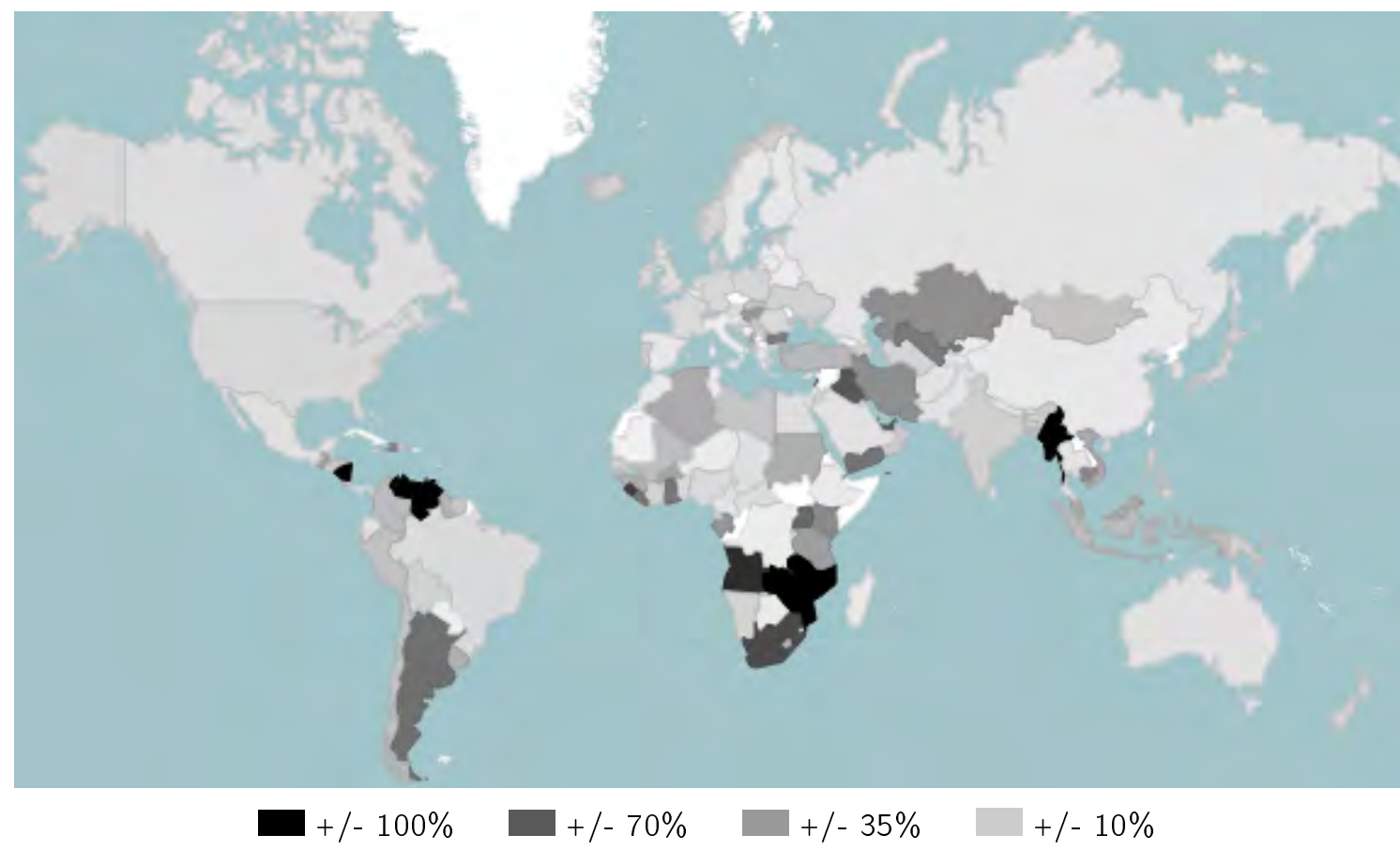

Figure 4 - Currency misalignments (in absolute values)

Source: Data correspond to the averages of estimates over the different models and weighting systems.

In this section, we provide a few figures and tables that offer more specific indications about the kind of analyses that are possible with EQCHANGE. Given margins of uncertainty inherent to ERER estimates, the magnitude of currency misalignments in absolute terms (for one country and one year) should be viewed with caution. ${ }^{23}$ it is therefore preferable to use ERER estimates to carry out analyses in relative terms, including the pattern of the world distribution of currencies' misalignments as well as the pattern of their evolutions and the factors underlining these dynamics.

\footnotetext{
22To express currency misalignments as a percentage, figures must be multiplied by 100 .

${ }^{23}$ This also encourages concentrating on substantial misalignments rather than on small deviations.
} 
Figure 4 maps currency misalignments (in absolute values) for the year 2016, the most recent year for which data are available. ${ }^{24}$ The most striking result is that currency misalignments in 2016 were weaker in advanced economies than in developing (DC) and emerging (EME) countries. The picture for EMEs and DCs is however quite diverse, highlighting important heterogeneity within those groups of countries. Substantial currency misalignments (greater than 100\%) are indeed observed in some countries like Angola, Mozambique, Myanmar, Nicaragua, Sierra Leone, Venezuela, Zambia and Zimbabwe. Other economies such as Argentina, Cambodia, South Africa, Iraq, Uganda, and the United Arab Emirates also displayed high currency misalignments, although of less magnitude.

Figures 5 and 6 provide further evidence on the configuration of global currency misalignments in 2016 by distinguishing countries whose currencies were undervalued (Figure 5) from those whose currencies were, on the contrary, overvalued (Figure 6).

As no model provides a precise answer on the magnitude of the misalignment, Tables 4 and 5 report the averages and standard deviations of estimated misalignments across the different types of specifications and for each country belonging to our sample. ${ }^{25}$

A significant point shown by Figures 5 and 6 is that undervalued and overvalued currencies were concentrated geographically. Indeed, in 2016 almost all the Asian economies as well as the Near and Middle East countries had undervalued currencies while in African economies, overvaluations were more frequent. Among European countries, undervaluations mostly prevailed in Western European countries - except in Portugal - though in different degrees: undervaluations were relatively sizeable in the core members of the euro zone, i.e. France, Germany and the Netherlands (around 15 to 10\%), while being more modest in Belgium, Cyprus, Finland, Italy, and Spain (below 5.5\%). In contrast, overvaluations mostly occurred in Eastern European countries.

In order to illustrate trends from 2015 to 2016, Figure 7 plots the distribution of misalignments' changes during this period. As can be seen, the distribution is slightly negatively skewed indicating a small tendency towards a reduction in currency misalignments from 2015 to 2016. The extent of these changes is also mixed, with about half of them reaching between -10 and +10 percentage points and with important disparities across

\footnotetext{
${ }^{24}$ Aruba, Cayman Islands, Cuba and Syria are excluded — for this particular year — due to data availability issues.

${ }^{25}$ Indeed, even if the different models point in the same direction with more or less similar results, it is preferable to know the confidence interval for the estimates (see also Figures C.3 in Appendix).
} 


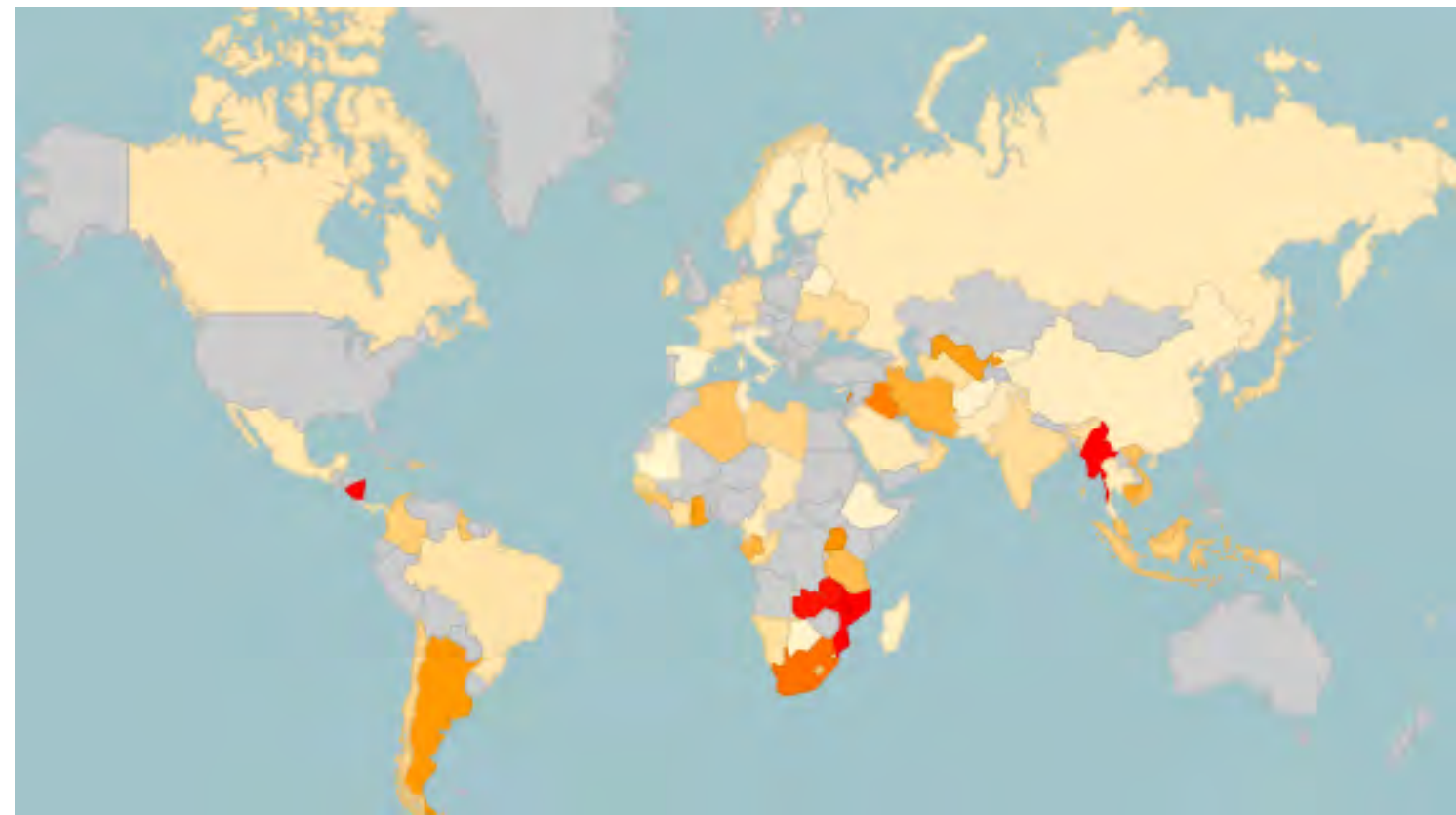
$+/-100 \%$
$+/-70 \%$
$+/-35 \%$
$+/-10 \%$

Figure 5 - Undervalued currencies

Source: Data correspond to the averages of estimates over the different models and weighting systems.

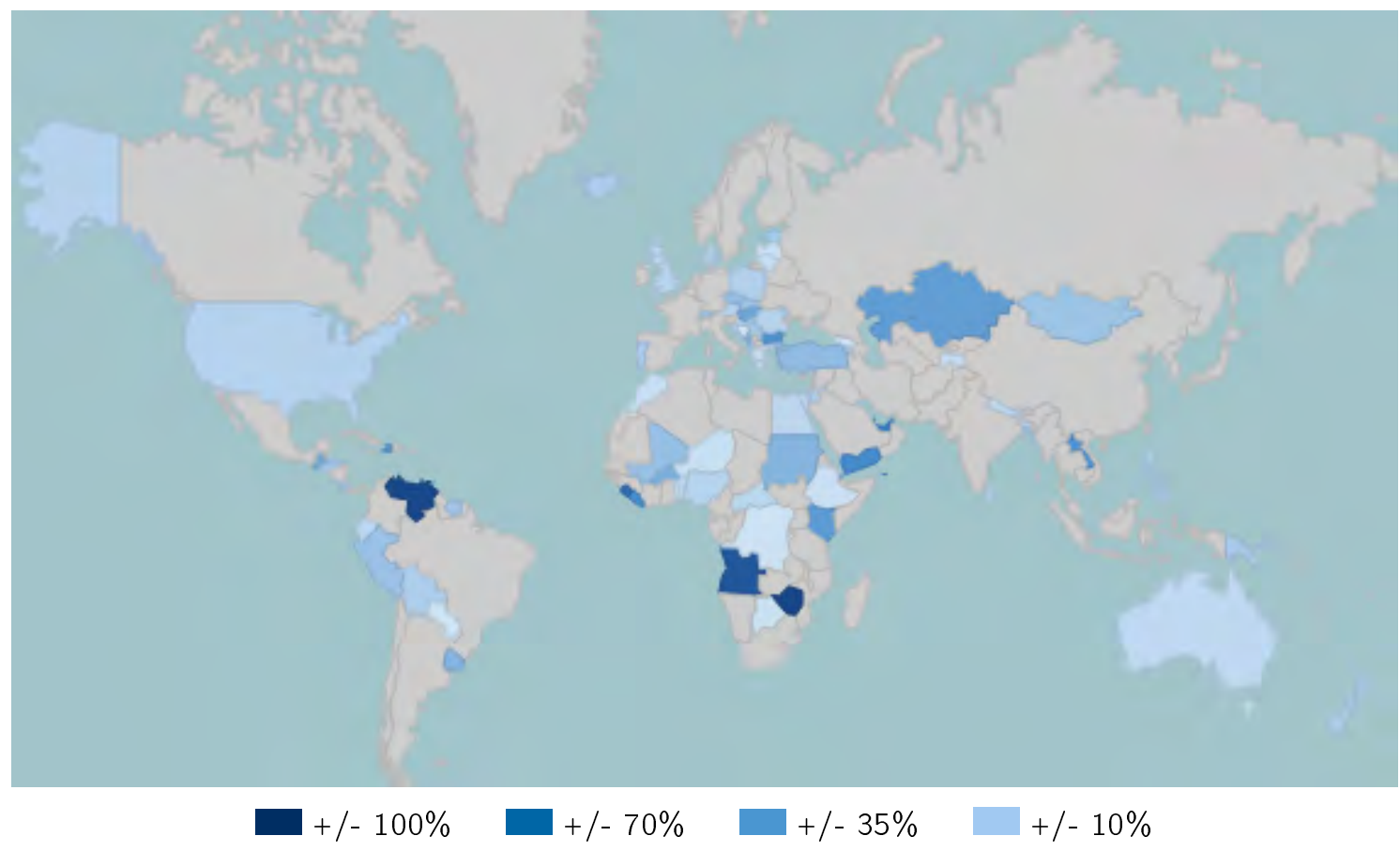

Figure 6 - Overvalued currencies

Source: Data correspond to the averages of estimates over the different models and weighting systems. 
Table 4 - Countries whose currencies are undervalued

\begin{tabular}{|c|c|c|c|c|c|}
\hline \multirow{2}{*}{ Country } & \multicolumn{2}{|c|}{ Misalignement } & \multirow{2}{*}{ Country } & \multicolumn{2}{|c|}{ Misalignment } \\
\hline & Mean & Std. Err. & & Mean & Std. Err. \\
\hline Nicaragua & -6.028 & 0.30 & Ireland & -0.148 & 0.07 \\
\hline Macedonia TFYR & -4.106 & 0.08 & Germany & -0.148 & 0.05 \\
\hline Myanmar & -2.291 & 0.13 & Equatorial Guinea & -0.136 & 0.16 \\
\hline Malawi & -1.759 & 0.29 & Bahrain & -0.136 & 0.02 \\
\hline Mozambique & -1.695 & 0.59 & France & -0.134 & 0.09 \\
\hline Zambia & -1.404 & 0.37 & Brazil & -0.128 & 0.07 \\
\hline South Africa & -0.950 & 0.10 & Netherlands & -0.108 & 0.05 \\
\hline Iraq & -0.872 & 0.98 & Canada & -0.108 & 0.02 \\
\hline Lebanon & -0.832 & 0.09 & Mexico & -0.101 & 0.02 \\
\hline Uganda & -0.776 & 0.09 & Chad & -0.100 & 0.03 \\
\hline Argentina & -0.740 & 0.06 & Korea Rep & -0.096 & 0.10 \\
\hline Ghana & -0.686 & 0.11 & Belize & -0.090 & 0.12 \\
\hline Uzbekistan & -0.676 & 0.02 & Jamaica & -0.086 & 0.12 \\
\hline Cambodia & -0.604 & 0.87 & Grenada & -0.083 & 0.20 \\
\hline Iran & -0.561 & 0.08 & Saudi Arabia & -0.081 & 0.05 \\
\hline Gabon & -0.513 & 0.10 & Afghanistan & -0.079 & 0.08 \\
\hline Tanzania & -0.463 & 0.15 & Cameroon & -0.077 & 0.12 \\
\hline Viet Nam & -0.391 & 0.55 & Russian Federation & -0.073 & 0.04 \\
\hline Algeria & -0.390 & 0.06 & Pakistan & -0.070 & 0.05 \\
\hline Malaysia & -0.380 & 0.07 & Dominica & -0.065 & 0.10 \\
\hline Guinea & -0.369 & 0.13 & Panama & -0.063 & 0.26 \\
\hline Guyana & -0.351 & 0.06 & Luxembourg & -0.059 & 0.02 \\
\hline Lesotho & -0.315 & 0.15 & Thailand & -0.057 & 0.08 \\
\hline Colombia & -0.308 & 0.06 & Spain & -0.055 & 0.09 \\
\hline Guinea Bissau & -0.297 & 0.18 & Finland & -0.054 & 0.07 \\
\hline Indonesia & -0.295 & 0.13 & Sweden & -0.053 & 0.04 \\
\hline Chile & -0.252 & 0.07 & China & -0.048 & 0.20 \\
\hline Libya & -0.250 & 0.26 & Madagascar & -0.045 & 0.07 \\
\hline Dominican Rep & -0.227 & 0.09 & Swaziland & -0.044 & 0.45 \\
\hline Oman & -0.223 & 0.13 & Belgium & -0.043 & 0.03 \\
\hline Senegal & -0.195 & 0.04 & Bhutan & -0.040 & 0.09 \\
\hline India & -0.185 & 0.12 & Tunisia & -0.035 & 0.07 \\
\hline Ukraine & -0.174 & 0.05 & Kyrgyzstan & -0.030 & 0.07 \\
\hline Congo & -0.172 & 0.11 & Belarus & -0.027 & 0.06 \\
\hline Norway & -0.168 & 0.11 & Fiji & -0.024 & 0.07 \\
\hline Côte d'Ivoire & -0.168 & 0.11 & Italy & -0.023 & 0.09 \\
\hline Azerbaijan & -0.168 & 0.14 & Cyprus & -0.014 & 0.10 \\
\hline Namibia & -0.167 & 0.10 & Saint Kitts and Nevis & -0.010 & 0.14 \\
\hline Sao Tome and Principe & -0.166 & 0.21 & Kiribati & -0.010 & 0.06 \\
\hline Turkmenistan & -0.164 & 0.05 & Slovenia & -0.003 & 0.03 \\
\hline Japan & -0.161 & 0.07 & Mauritania & -0.001 & 0.09 \\
\hline Rwanda & -0.156 & 0.14 & & & \\
\hline
\end{tabular}

Note: The values in the column "Mean" (resp. "Std. Err.") correspond to the averages (resp. standard errors) of the estimates over all the specifications (i.e. models, number of trade partners, and weighting systems). To express currency misalignments as a percentage, figures in the "Mean" columns must be multiplied by 100. 
Table 5 - Countries whose currencies are overvalued

\begin{tabular}{|c|c|c|c|c|c|}
\hline \multirow{2}{*}{ Country } & \multicolumn{2}{|c|}{ Misalignement } & \multirow{2}{*}{ Country } & \multicolumn{2}{|c|}{ Misalignment } \\
\hline & Mean & Std. Err. & & Mean & Std. Err. \\
\hline Paraguay & 0.001 & 0.04 & Philippines & 0.169 & 0.06 \\
\hline Bosnia Herzegovina & 0.003 & 0.09 & New Zealand & 0.171 & 0.06 \\
\hline Georgia & 0.006 & 0.07 & Bolivia & 0.174 & 0.08 \\
\hline Antigua and Barbuda & 0.013 & 0.15 & Portugal & 0.179 & 0.09 \\
\hline Congo DR & 0.016 & 0.03 & Maldives & 0.181 & 0.09 \\
\hline Burundi & 0.017 & 0.14 & Bangladesh & 0.184 & 0.03 \\
\hline Botswana & 0.021 & 0.06 & Iceland & 0.185 & 0.19 \\
\hline Latvia & 0.023 & 0.05 & Papua New Guinea & 0.197 & 0.08 \\
\hline Niger & 0.036 & 0.17 & Estonia & 0.211 & 0.07 \\
\hline Ethiopia & 0.038 & 0.13 & Serbia & 0.216 & 0.06 \\
\hline Togo & 0.041 & 0.11 & Armenia & 0.220 & 0.07 \\
\hline Morocco & 0.044 & 0.04 & Moldova Rep & 0.223 & 0.03 \\
\hline Saint Lucia & 0.049 & 0.13 & Suriname & 0.228 & 0.08 \\
\hline Lithuania & 0.049 & 0.08 & Slovakia & 0.234 & 0.04 \\
\hline Brunei Darussalam & 0.050 & 0.16 & Albania & 0.238 & 0.10 \\
\hline Tajikistan & 0.054 & 0.11 & Honduras & 0.243 & 0.05 \\
\hline Tonga & 0.056 & 0.04 & Costa Rica & 0.244 & 0.04 \\
\hline Greece & 0.057 & 0.08 & Mongolia & 0.250 & 0.13 \\
\hline Bahamas & 0.057 & 0.03 & Peru & 0.262 & 0.06 \\
\hline Seychelles & 0.067 & 0.15 & Switzerland & 0.265 & 0.06 \\
\hline Israel & 0.069 & 0.08 & Gambia & 0.279 & 0.12 \\
\hline El Salvador & 0.078 & 0.20 & Mali & 0.292 & 0.29 \\
\hline Mauritius & 0.081 & 0.19 & Czechia & 0.297 & 0.05 \\
\hline Nepal & 0.085 & 0.11 & Turkey & 0.316 & 0.12 \\
\hline Australia & 0.090 & 0.13 & Uruguay & 0.368 & 0.08 \\
\hline Ecuador & 0.093 & 0.06 & Sudan & 0.372 & 0.05 \\
\hline Marshall Islands & 0.094 & 0.02 & Barbados & 0.389 & 0.07 \\
\hline Singapore & 0.094 & 0.14 & Montenegro & 0.401 & 0.09 \\
\hline Egypt & 0.097 & 0.12 & Burkina Faso & 0.422 & 0.32 \\
\hline Benin & 0.098 & 0.07 & Guatemala & 0.445 & 0.05 \\
\hline Kuwait & 0.104 & 0.21 & Trinidad and Tobago & 0.466 & 0.05 \\
\hline Central African Rep & 0.111 & 0.13 & Hungary & 0.485 & 0.26 \\
\hline Sri Lanka & 0.115 & 0.11 & Djibouti & 0.523 & 0.05 \\
\hline United Kingdom & 0.117 & 0.04 & Haiti & 0.559 & 0.06 \\
\hline Cabo Verde & 0.119 & 0.18 & Kazakhstan & 0.559 & 0.21 \\
\hline Samoa & 0.120 & 0.06 & Kenya & 0.585 & 0.10 \\
\hline Nigeria & 0.121 & 0.06 & Qatar & 0.593 & 0.46 \\
\hline Denmark & 0.123 & 0.06 & Malta & 0.614 & 0.29 \\
\hline China Hong Kong SAR & 0.123 & 0.06 & Lao PDR & 0.655 & 0.26 \\
\hline Austria & 0.124 & 0.05 & Bulgaria & 0.660 & 0.26 \\
\hline Solomon Islands & 0.127 & 0.08 & Liberia & 0.694 & 0.41 \\
\hline Romania & 0.129 & 0.12 & Yemen & 0.706 & 0.04 \\
\hline USA & 0.138 & 0.05 & United Arab Emirates & 0.856 & 0.44 \\
\hline Croatia & 0.139 & 0.02 & Sierra Leone & 1.027 & 0.24 \\
\hline Comoros & 0.139 & 0.12 & Angola & 1.320 & 1.19 \\
\hline Poland & 0.149 & 0.10 & Venezuela & 3.343 & 0.08 \\
\hline Vanuatu & 0.155 & 0.09 & Zimbabwe & 39.326 & 0.58 \\
\hline Jordan & 0.163 & 0.10 & & & \\
\hline
\end{tabular}


countries and regions.

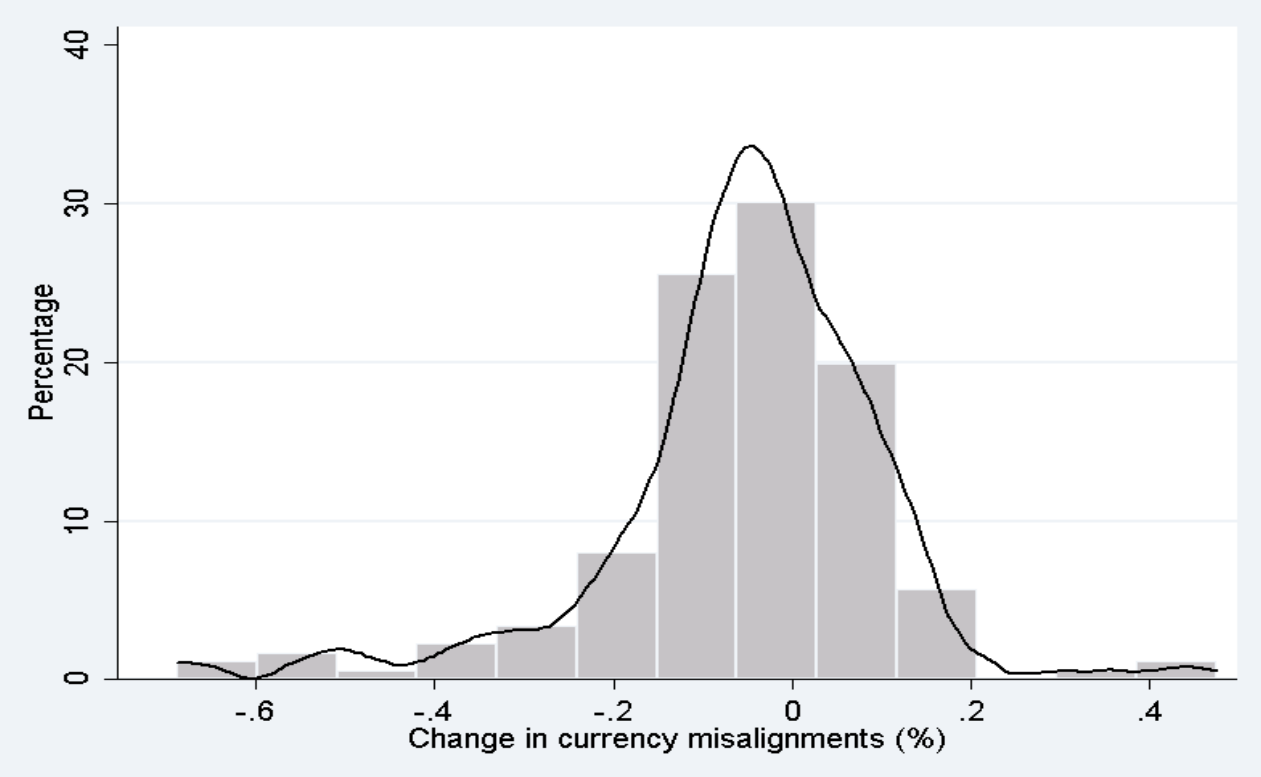

Figure 7 - Distribution of the changes in currency misalignments Note: We excluded 5 outliers (Macedonia, Myanmar, Nicaragua, Venezuela and Zimbabwe). The black line represents the kernel density.

This disparity across countries primarily reflects two factors. First, the persistence of weak oil prices between 2015 and 2016 continued to affect in different ways equilibrium exchange rates of commodity exporters and of non-resource-intensive countries. Second, many commodity exporters with flexible exchange rate regimes faced sizeable currency depreciation in response to weakening commodity prices, while countries with pegged currencies couldn't, by definition, benefit from this coping mechanism. Figure 8 shows the geographical configuration of changes in currency misalignments, while Figures 9 illustrate the extent to which these evolutions have been related to variations in real effective exchange rates and/or in equilibrium real exchange rates. The countries can then be classified in several categories, according to the evolutions of their ERER and their REER. Policy implications about changes in misalignments can also be drawn on a number of grounds, including the magnitude of these variations (small or large), the direction of these changes (improvement or worsening) and finally the roots of these evolutions (depending on whether they come from an improvement in fundamentals or an adjustment in the real effective exchange rate).

Regarding the magnitude of changes in currency misalignments, the first bisector in Figures 9 represents all the countries for which evolutions in real effective exchange rates have been in line with those in underlying fundamentals. By definition, countries that are located close to this first bisector, or approach it, have registered small variations 
in their currencies' misalignments from 2015 to 2016 (graphs on the left in Figures 9). For the other countries, currencies' misalignments have evolved markedly (graphs on the right in Figures 9). These changes have reflected either a worsened situation (large increases in misalignments, graph top right) or an improved situation (large reductions of misalignments, graph below right).

The first category of countries, where the situation has worsened, have registered an increased overvaluation (or an increased undervaluation) of their currency because they have been confronted either with worsened (improved) fundamentals ( $y$-axis) or with a sharp appreciation (depreciation) of their real exchange rate (x-axis). ${ }^{26}$ On the contrary, the second category of countries, where the situation has improved, have registered a reduction in the overvaluation (or a reduced undervaluation) of their currency because they have recorded either improved (worsened) fundamentals (y-axis) or a sharp depreciation (appreciation) of their real exchange rate (x-axis). ${ }^{27}$

Finally, Figure 10 documents the geographical configuration of changes in the fundamentals of real effective exchange rates.

Figure 8 clearly illustrates that the most sizeable changes from 2015 to 2016 were concentrated in four emerging and developing countries. More specifically, overvaluations increased relatively steady in Venezuela and Zimbabwe due to the worsening of their economic situation (slowdown in economic growth and high level of annual inflation in Venezuela; decline of food exports in Zimbabwe). In contrast, overvaluations fall sharply in Argentina and Libya.

In advanced economies, changes in currency misalignments were much lower. In the United States, the real effective exchange rate appreciated by 18 percent, resulting in an increased overvaluation of the US dollar (Figure 9.b). This in part reflected the relative strengthening of the economy compared to most trading partners. In contrast, in Canada, the marked decline in oil prices was accompanied by an increase in the undervaluation of the currency. This evolution was mostly driven by a weaker Canadian dollar which depreciated by 18 percent in real effective terms (Figure 9.b). The decline in commodity prices had also a notable impact on other advanced commodity-exporting

\footnotetext{
${ }^{26}$ More specifically, in the graph top right, countries that have registered an increased undervaluation are located above the first bisector, whereas countries that have recorded an increased overvaluation of their currency are below this line.

${ }^{27}$ More specifically, in the graph below right, countries that have registered a decrease in the overvaluation are located above the first bisector, whereas countries that have recorded a decrease in the undervaluation of their currency are below this line.
} 


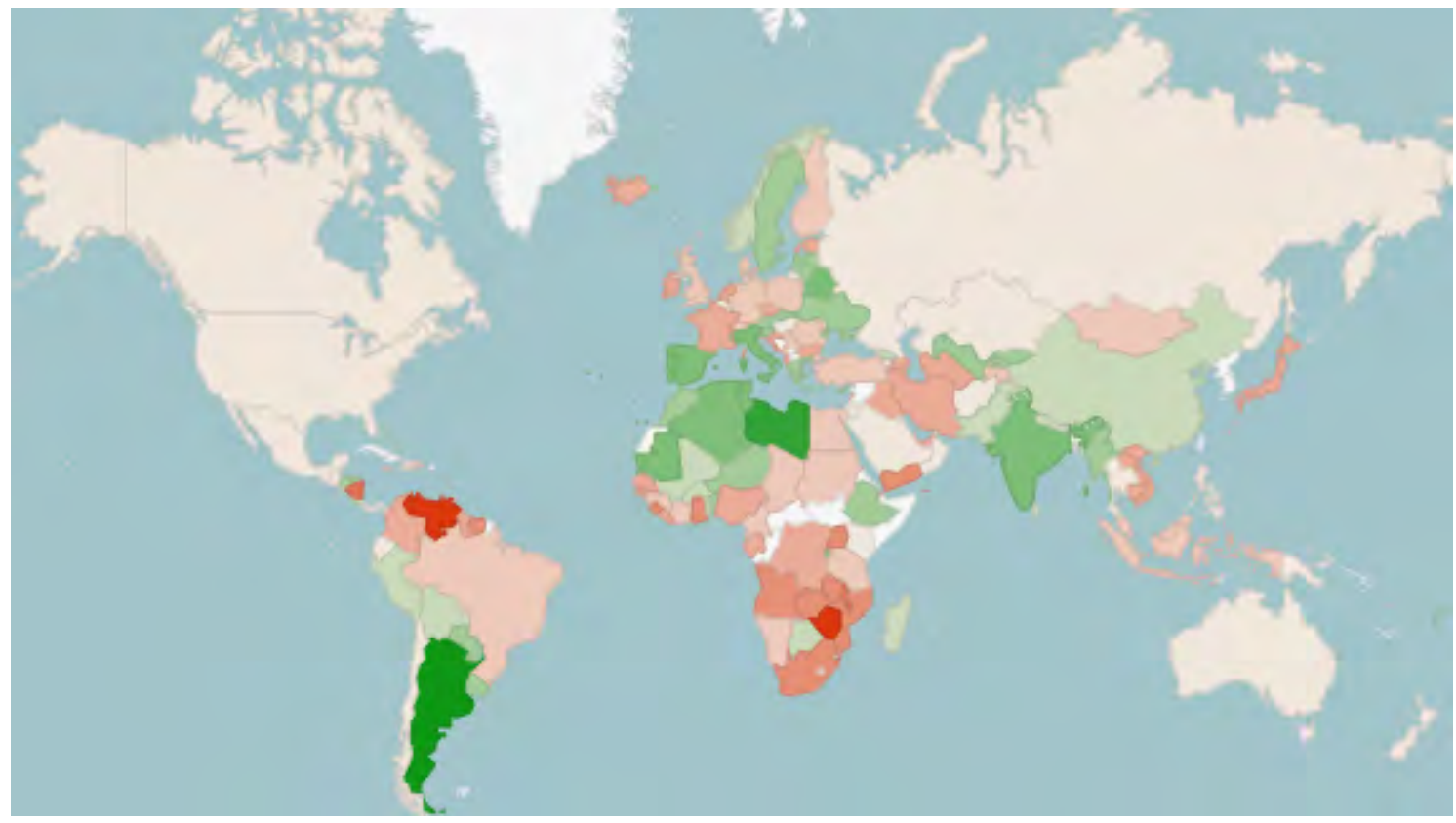

$\leftarrow$ Increase of Mis.

$\mid \Delta$ Mis. $\mid \leq 5$ p.p.

Reduction of Mis. $\rightarrow$

Figure 8 - Changes in currency misalignments between 2015 and 2016 Source: Data correspond to changes (in percentage point) in the average misalignments.

countries such as Australia and Norway. The overvaluation of the Australian dollar increased further due to worsened fundamentals (Figure 9.e), while Norway experienced a decrease in its currency's overvaluation due to the depreciation of its real exchange rate (Figure 9.d). In the euro area (Figure 9.d), the depreciation of the euro coupled with some structural reforms and internal devaluations caused a generalized movement of real depreciations. This general trend led currencies of most peripheral countries being less overvalued and currencies of the core members (especially in France, Germany and the Netherlands) more undervalued. As can be seen in Figure 9.d, reduced overvaluations in the peripheral countries were not driven by stronger fundamentals. Instead they occurred mostly because of depreciated real exchange rates. Therefore it is quite likely that this correction will not be sustainable in the long run. In contrast, the livre sterling appreciated by 25 percent from 2015 to 2016, which resulted in the increase of the currency's overvaluation (Figure 9.d). In 2016 the undervaluation of the Japanese yen increased. This trend mainly reflected the effects of the depreciation of the real exchange rate, partly driven by the strong monetary expansion adopted by the government since early 2013 (Figure 9.c).

Trends across emerging markets and developing economies also displayed heterogeneity. Real exchange rate depreciations occurred in Russia and Ukraine and offset deteriorating fundamentals, especially in the Russian case. This resulted in a sharp decrease of the 
Ukrainian hryvnia's overvaluation and a weak increase of the Russian ruble's undervaluation. In Western Balkans, the large real appreciations (except in Macedonia) exacerbated most of the pre-existing exchange rate misalignments in these countries (Figure 9.d).

Most Latin American countries were confronted with lower growth (Figure 10.a). Most of them let their currencies depreciate in response to the terms-of-trade shock, which resulted in rather small increased undervaluations (as in Brazil, Chile and Colombia). However, in a few cases sharp changes in currency misalignments occurred. In Argentina, the new policy framework implemented by the government resulted in stronger fundamentals. This improvement coupled to the depreciation of the real exchange rate led to a substantial fall of the overvaluation of the peso. In Venezuela, the strong appreciation of the real exchange rate combined with lower commodity prices, fiscal imbalances and political tensions induced a sharp rise of the currency overvaluation (Figure 9.b).

In Asia (Figure 9.c), real exchange rates rather appreciated across most of the region, following the appreciation trend of the US dollar or reflecting higher relative inflation. In East Asia, the changes have been generally coincided with small (i.e., below 10 percent) increase in misalignments, except in Lao, Cambodia and Vietnam where the misalignments were higher and tended to follow the improvement in fundamentals (Vietnam and Cambodia) or the sharp appreciation of the real exchange rate (as in Lao). The Middle East was confronted not only with a sizeable negative terms-of-trade shock associated with the decline in commodity prices (Figure 10.c), but also with difficult challenges regarding geopolitical tensions, unrest and civil conflict (Syria). In some countries (such as Israel, Jordan, Kuwait, Qatar and Yemen), the large real appreciations exacerbated most of the pre-existing overvaluations, while in others (Bahrain, Oman, Saudi Arabia, Lebanon, Iraq and Iran) the improvement in fundamentals resulted in increased undervaluations (Figure 9.c). 

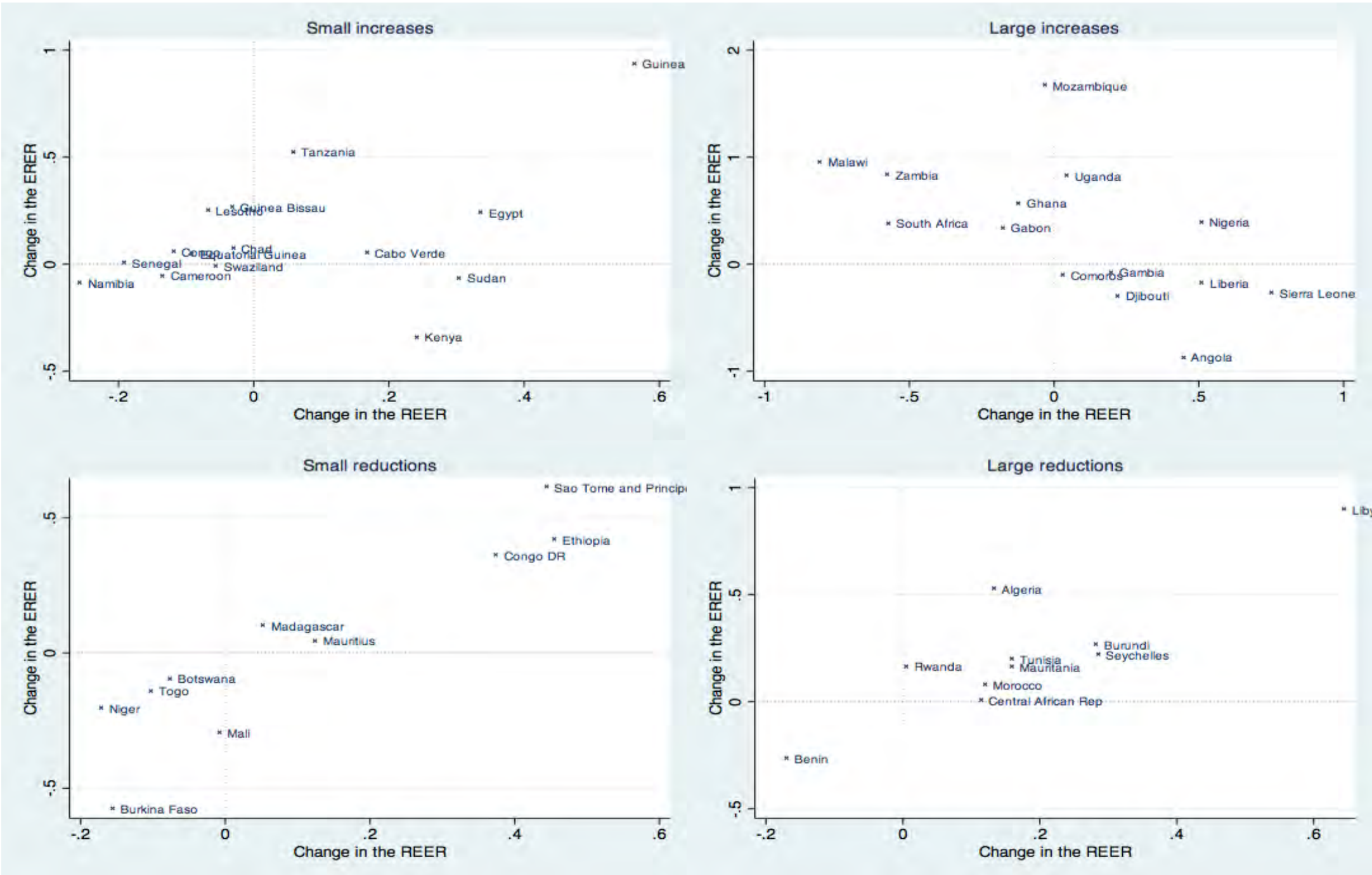

Figure 9.a - Africa | Changes in currency misalignments (2015-2016): $\triangle E R E R$ vs. $\triangle R E E R$

Note: Zimbabwe has been excluded from the "Large increases" panel as it distorts the graph. We used the median of the negative (resp. positive) values of the changes in the currency misalignments as threshold to differentiate between Small and Large reductions (resp. increases). The $x$-axis provides the contribution of a variation in the REER to a change in misalignment between 2015 and 2016; the y-axis gives the contribution of a variation in fundamentals to a change in misalignment between 2015 and 2016. 

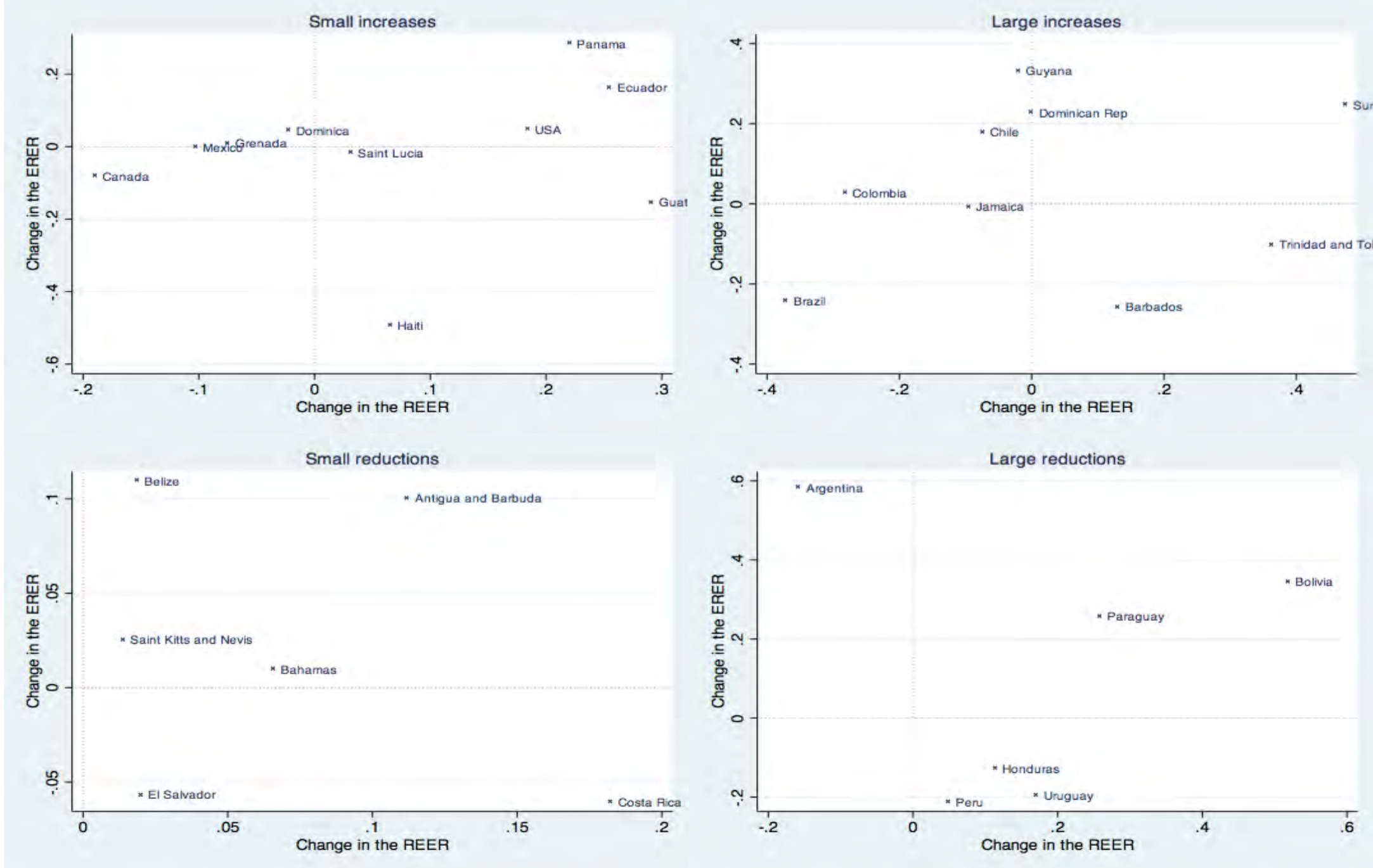

Figure 9.b - America | Changes in currency misalignments (2015-2016): $\triangle E R E R$ vs. $\triangle R E E R$

Note: Nicaragua and Venezuela have been excluded from the "Large increases" panel as they distort the graph. We used the median of the negative (resp. positive) values of the changes in the currency misalignments as threshold to differentiate between Small and Large reductions (resp. increases). The $\mathrm{x}$-axis provides the contribution of a variation in the REER to a change in misalignment between 2015 and 2016; the $y$-axis gives the contribution of a variation in fundamentals to a change in misalignment between 2015 and 2016. 

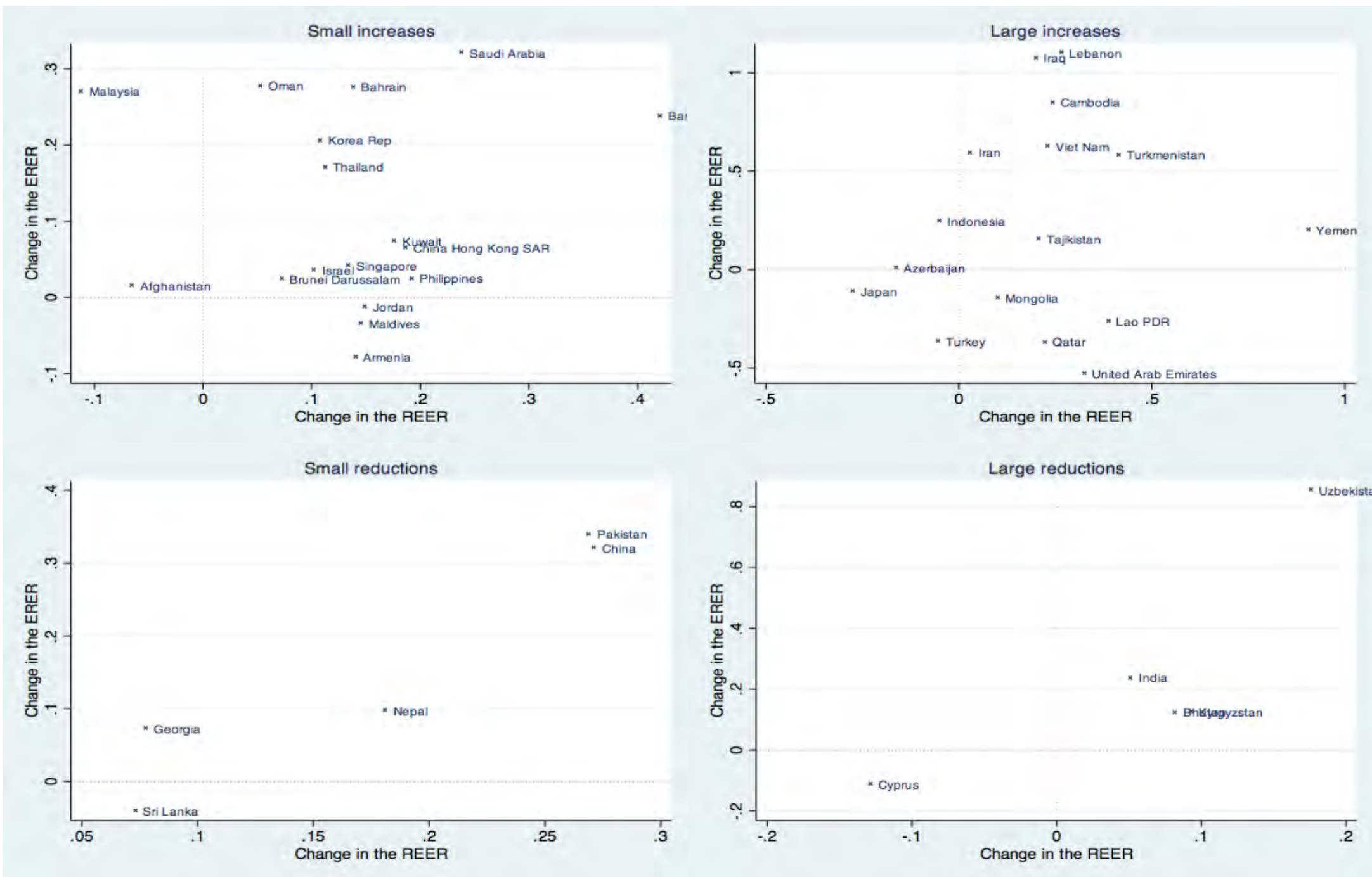

Figure 9.c - Asia | Changes in currency misalignments (2015-2016): $\triangle E R E R$ vs. $\triangle R E E R$

Note: Kazakhstan and Myanmar have been respectively excluded from the "Small increases" and "Large reductions" panel as they distort the graph. We used the median of the negative (resp. positive) values of the changes in the currency misalignments as threshold to differentiate between Small and Large reductions (resp. increases). The $x$-axis provides the contribution of a variation in the REER to a change in misalignment between 2015 and 2016; the y-axis gives the contribution of a variation in fundamentals to a change in misalignment between 2015 and 2016. 

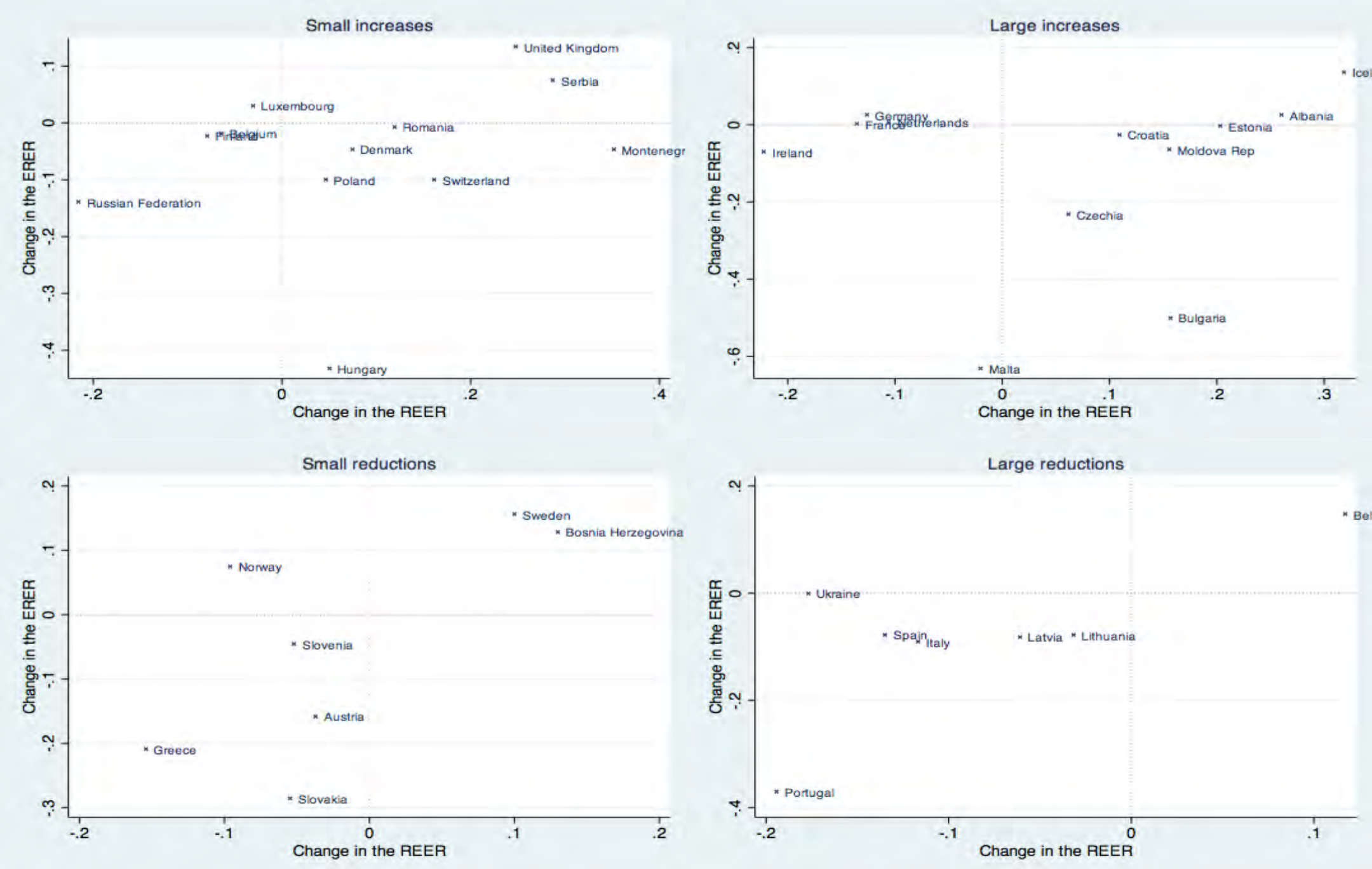

Figure 9.d - Europe | Changes in currency misalignments (2015-2016): $\triangle E R E R$ vs. $\triangle R E E R$

Note: Macedonia has been excluded from the "Large increases" panel as it distorts the graph. We used the median of the negative (resp. positive) values of the changes in the currency misalignments as threshold to differentiate between Small and Large reductions (resp. increases). The $x$-axis provides the contribution of a variation in the REER to a change in misalignment between 2015 and 2016; the y-axis gives the contribution of a variation in fundamentals to a change in misalignment between 2015 and 2016. 

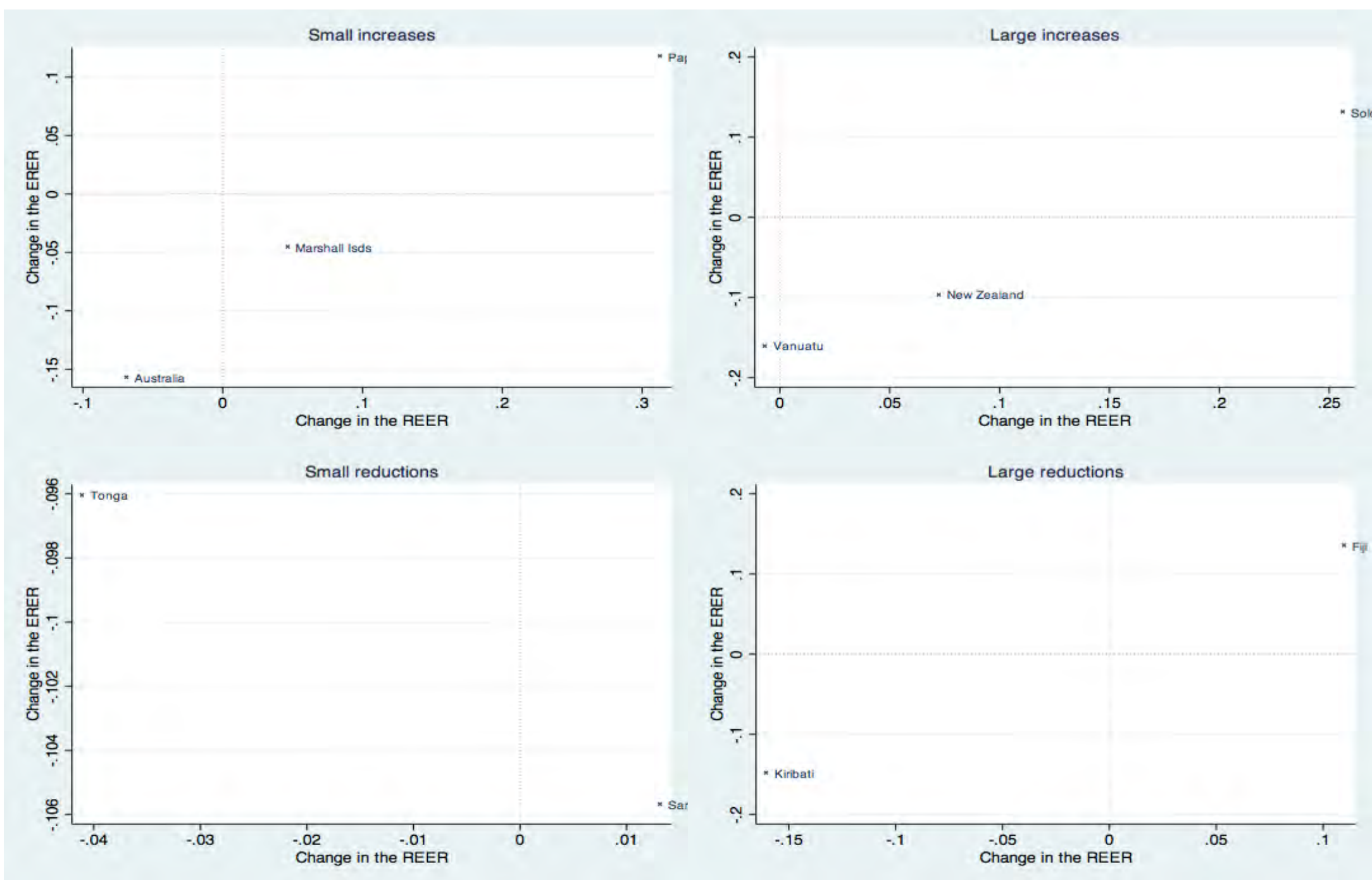

Figure 9.e - Oceania | Changes in currency misalignments (2015-2016): $\triangle E R E R$ vs. $\triangle R E E R$

Note: We used the median of the negative (resp. positive) values of the changes in the currency misalignments as threshold to differentiate between Small and Large reductions (resp. increases). The x-axis provides the contribution of a variation in the REER to a change in misalignment between 2015 and 2016 ; the $y$-axis gives the contribution of a (resp. increases). The x-axis provides the contribution of a variation in the REER
variation in fundamentals to a change in misalignment between 2015 and 2016. 


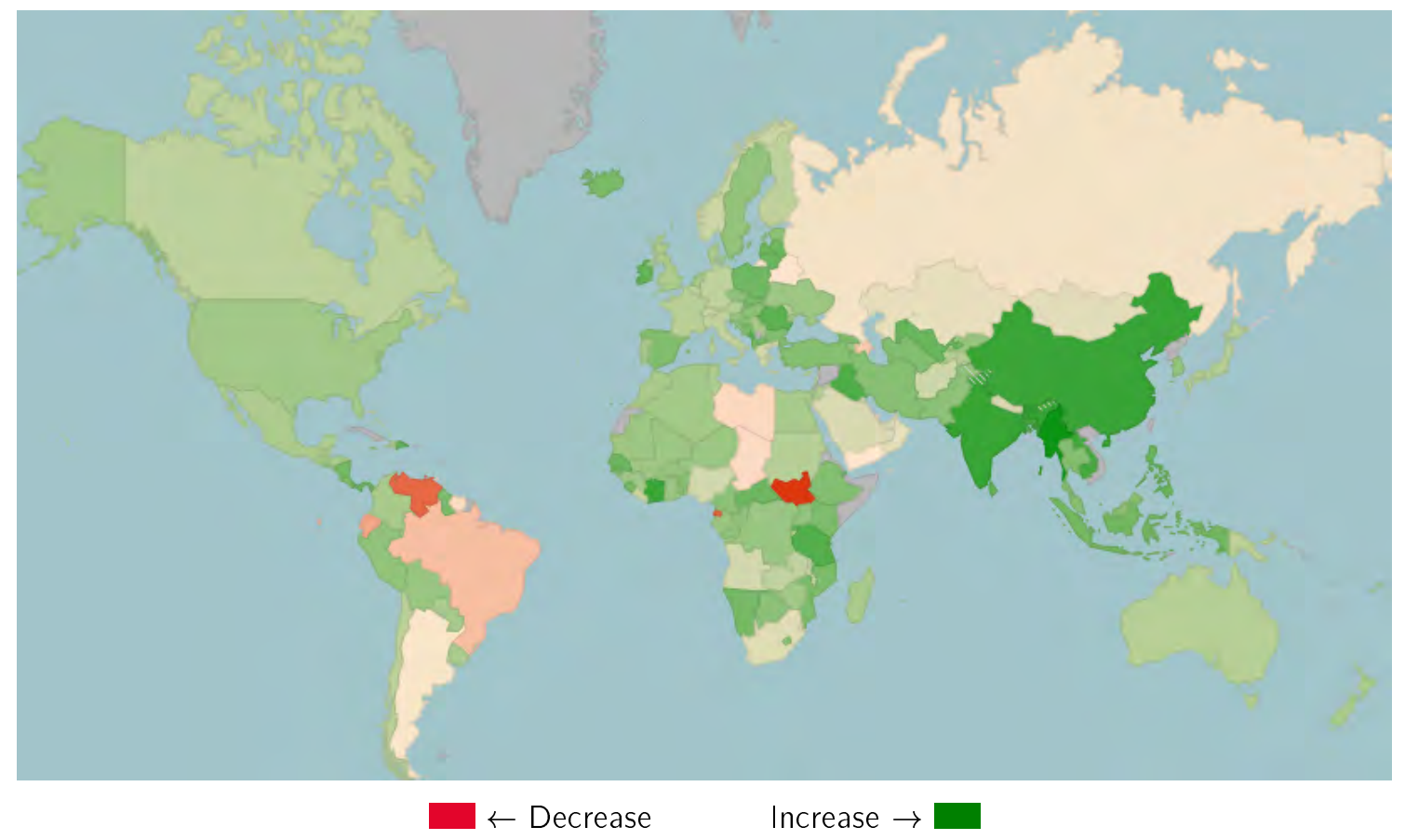

Figure 10.a - Changes in real GDP per capita (in PPP terms) between 2015 and 2016

Finally, Sub-Saharan Africa also faced challenging conditions due not only to economic factors but also to droughts in Southern Africa (Lesotho, Malawi, Zambia, and Zimbabwe), pests and security issues. Currency misalignments of several oil and commodity exporters (such as Angola and Zimbabwe) rose sharply and resulted in increased overvaluations due to worsened fundamentals. In particular the deterioration of net foreign asset positions was a main factor behind the worsening of fundamentals in this region (Figure 10.b). On the contrary, other countries (such as Malawi and Zambia) registered increased undervaluations due to depreciated real exchange rates and appreciated equilibrium real exchange rates (Figure 9.a). 


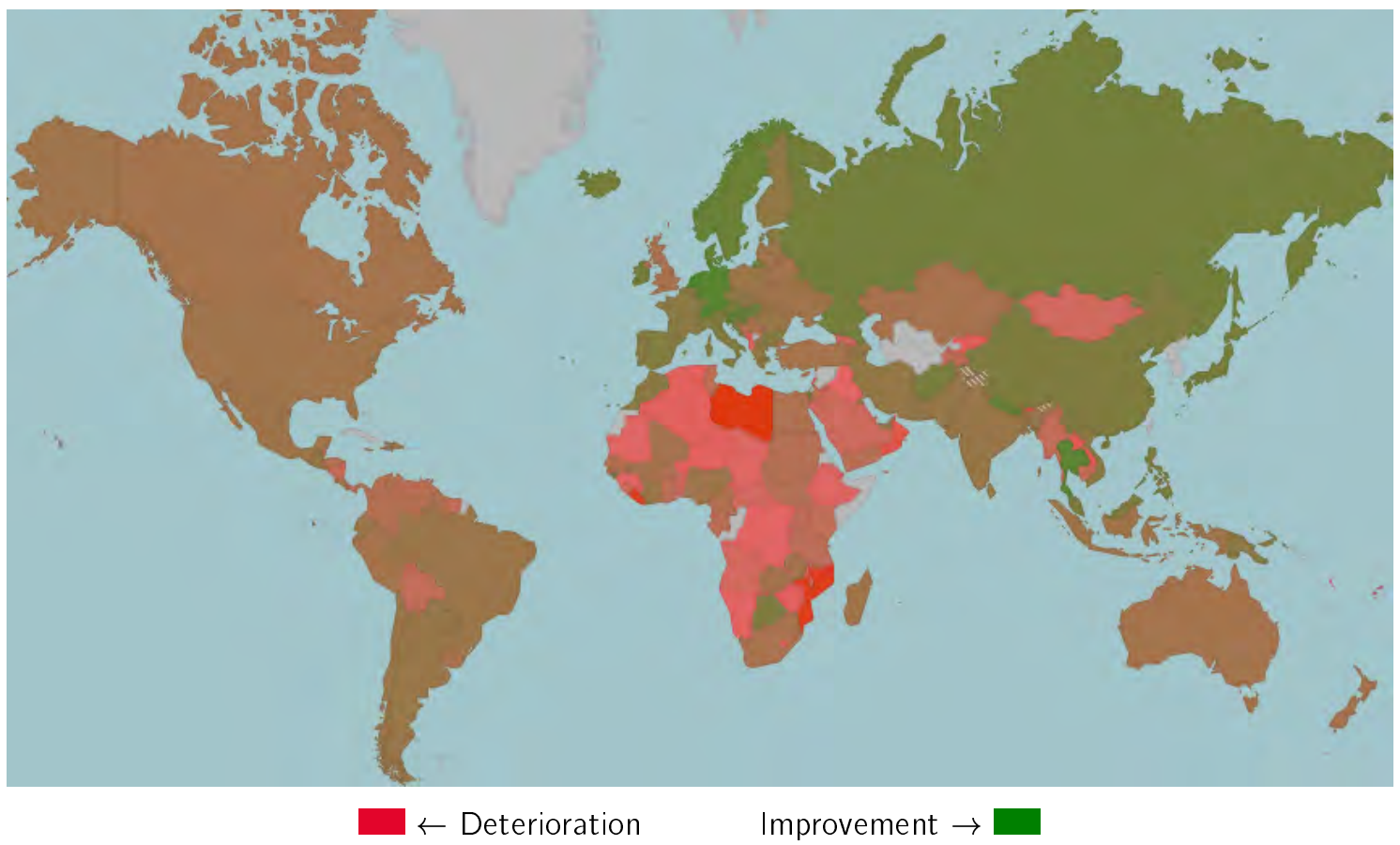

Figure 10.b - Changes in the net foreign asset positions between 2015 and 2016

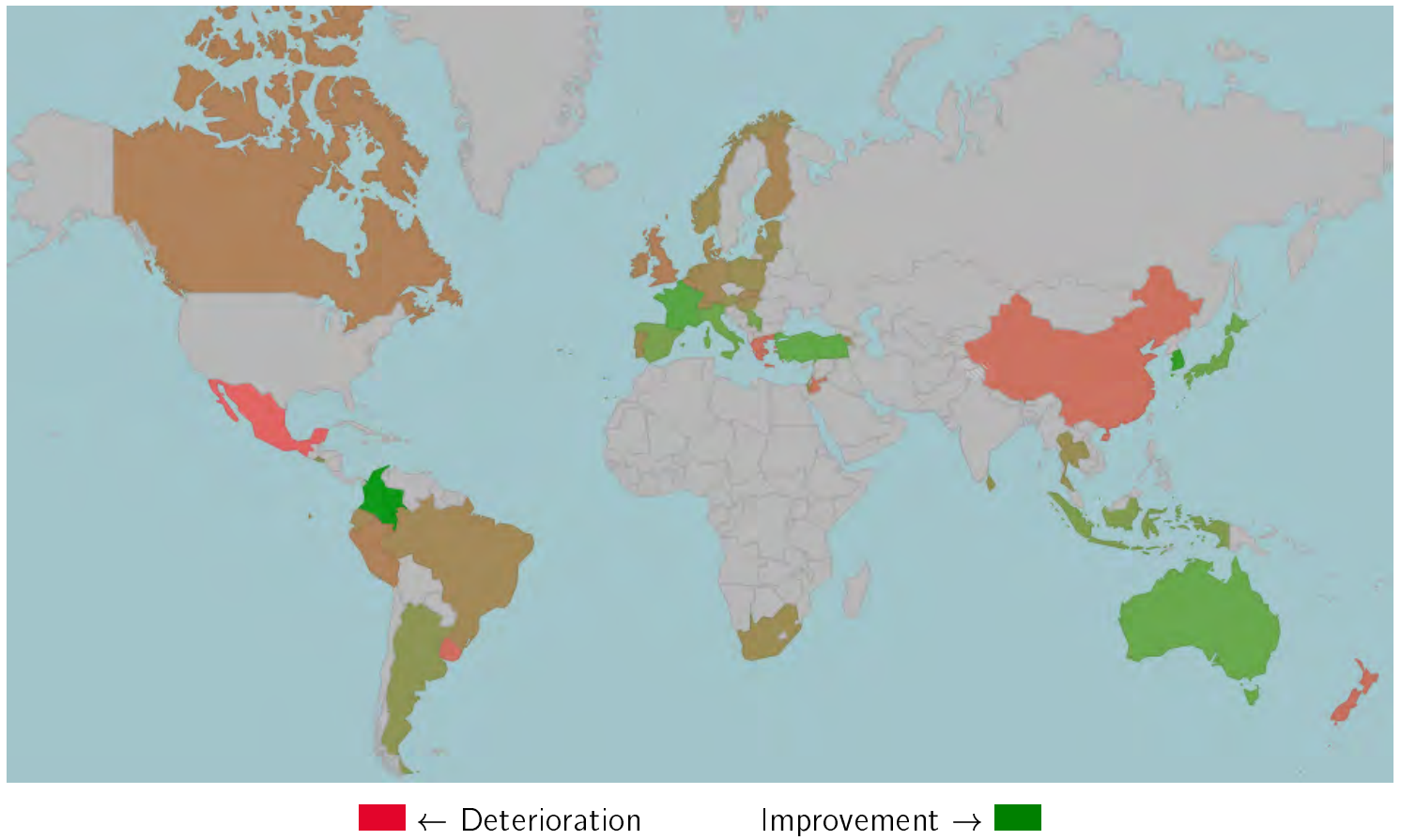

Figure 10.c - Changes in the terms of trade between 2015 and 2016 


\section{Conclusion}

In order to create regular and public resources which consistently document currency misalignments across countries and over a reasonably long time-span, the CEPII has developed EQCHANGE, a world database on effective exchange rates. This paper describes the design and implementation of this database.

EQCHANGE relies on the creation of two datasets - one on effective exchange rates, the other one on equilibrium real effective exchange rates and corresponding currency misalignments - and innovates in a number of ways. The first sub-database on effective exchange rates is the most complete available database in terms of countries/time coverage as it provides indices of nominal and real effective exchange rates for 187 economies over the 1973-2016 period. Moreover, those indices are calculated under several assumptions (related to the weighting scheme and to the panel of trading partners). The second sub-database on equilibrium exchange rates and corresponding currency misalignments represents by far the most substantial contribution introduced by EQCHANGE. The different series provided by this dataset are available for 182 economies with data also ranging from 1973 to 2016. Equilibrium exchange rates are estimated using the BEER approach. However, to take into account the sensibility of these estimates to the choice of fundamentals and of the countries' sample, estimations are run under three different reduced equations of the real effective exchange rate and over various sub-samples of economies. Several currency misalignments can then be deduced depending on the selection of real effective exchange rates indices, the equilibrium exchange rate model and countries' sample.

Therefore, in delivering different series of effective exchange rates and of equilibrium exchange rates, the EQCHANGE database conducted by the CEPII provides different "consistent" estimates of currency misalignments that facilitate cross-country comparisons and also documents, for each country, the various factors affecting these currency misalignments. To illustrate this, the paper also presents the evolution and main traits of the world configuration of currency misalignments from 2015 to 2016.

The EQCHANGE database may have several other potential applications. Indeed, it should be used not only to assess, track, and monitor currency misalignments, but also to better understand the effects of these distortions on many aspects of the functioning of economies, such as on the efficiency of resource allocation, economic growth and global imbalances. 


\section{References}

Alberola, E. (2003). Misalignment, liabilities dollarization and exchange rate adjustment in Latin America, Banco de España, Working Paper 0309.

Alberola, E., Cervero, S., López, H., Ubide, A. (1999). Global equilibrium exchange rates: euro, dollar, ins, outs, and other major currencies in a panel cointegration framework, IMF Working Paper WP/99/175.

Balassa, B. (1964). The purchasing power parity doctrine: A reappraisal, Journal of Political Economy 72: 584-596.

Bénassy-Quéré, A., Béreau, S., Mignon, V. (2008). Equilibrium Exchange Rates: a Guidebook for the Euro-Dollar Rate, CEPII Working Paper, 2008-02.

Bénassy-Quéré, A., Béreau, S., Mignon, V. (2010). On the Complementarity of Equilibrium Exchange-Rate Approaches, Review of International Economics 18(4): 618-632.

Bénassy-Quéré, A., Duran-Vigneron, P., Mignon, V., Lahrèche-Révil, A., (2004). Burden Sharing and Exchange Rate Misalignments within the Group of Twenty, CEPII Working Paper, 2004-13.

Carton, B., Hervé, K. (2013). Is There any Rebalancing in the Euro Area?, CEPII Working Paper, 2013-32.

Clark, P., MacDonald, R. (1998). Exchange rates and economic fundamentals: a methodological comparison of BEERs and FEERs, IMF working paper 98/00.

Cline, W.R. (2008). Estimating Consistent Fundamental Equilibrium Exchange Rates, Working Paper 08-6 (July), Washington: Peterson Institute for International Economics.

Cline, W.R., Williamson, J. (2008). New Estimates of Fundamental Equilibrium Exchange Rates, Policy Brief, Peterson Institute for International Economics.

Coudert, V., Couharde, C., Mignon, V. (2013). Do real exchange rates still matter within the euro area?, Review of International Economics 21(1): 35-48.

Couharde, C., Delatte, A-L., Grekou, C., Mignon, V., Morvillier, F. (2017). Sur- et sous-évaluations de change en zone euro: vers une correction soutenable des déséquilibres?, La Lettre du CEPII, N³75, March 2017.

De Gregorio, J., Wolf, H. (1994). Terms of Trade, Productivity and the Real Exchange Rate, NBER Working Paper No. 4807, National Bureau of Economic Research, Cambridge, MA.

Driver, R., Westaway, P.F. (2004). Concepts of equilibrium exchange rates, Bank of England Working Paper $\mathrm{n}^{\circ} 248$.

Edwards, S. (1988). Real and monetary determinants of real exchange rate behavior: 
Theory and evidence from developing countries, Journal of Development Economics 29(3): 311- 341.

Elbadawi, I. (1994). Estimating Long-Run Equilibrium Real Exchange Rates, in J. Williamson (ed.), Estimating Equilibrium Exchange Rates, Washington, D.C.: Institute for International Economics.

Elbadawi, I., Soto, R. (2008). Theory and empirics of real exchange rates in developing countries, Documentos de trabajo 324, Instituto de Economica, Pontificia Universidad Católica de Chile.

Faruqee, H. (1995). Long-run determinants of the real exchange rate: A stockflow perspective, IMF Staff Papers, 42(1): 80-107.

Hausman, J.A. (1978). Specification Tests in Econometrics, Econometrica 46(6): 1251-1271.

Hinkle, L., Montiel, P. (1999). Exchange Rate Misalignment: Concepts and Measurement for Developing Countries, Oxford: Oxford University Press.

IMF (2006). Methodology for CGER Exchange Rate Assessments, International Monetary Fund, Washington DC.

https://www.imf.org/external/np/pp/eng/2006/110806.pdf

Lane, P.R., Milesi-Ferretti, G.M., (2002). External wealth, the trade balance, and the real exchange rate, European Economic Review 46(6): 1049-1071.

Lane, P.R., Milesi-Ferretti, G.M., (2007). The external wealth of nations mark II: Revised and extended estimates of foreign assets and liabilities, 1970-2004, Journal of International Economics 73: 223-250.

MacDonald, R. (2000). Concepts to Calculate Equilibrium Exchange Rates: An Overview, Discussion paper 3/00, Economic Research Group of the Deutsche Bundesbank.

Pesaran, M.H., Shin, Y., Smith, R.P.. Pooled Mean Group Estimation of Dynamic Heterogeneous Panels, Journal of the American Statistical Association 94(446): 621634.

Samuelson, P. (1964). Theoretical notes on trade problems, Review of Economics and Statistics 46: 145-154.

Rosensweig, J.A. (1987). Exchange Rate Index Construction: With a US Dollar Application, Journal of Foreign Exchange and International Finance 1(3): 293-301.

Turner, P., Van't dack, J. (1993). Measuring international price and cost competitiveness, BIS Economic Papers No 39, Bank for International Settlements, Basel, Swizterland.

Williamson, J. (1994). Estimates of FEERs, in Estimating Equilibrium Exchange Rates, ed. by John Williamson, Washington: Institute for International Economics. 


\section{Appendices}

\section{A. Data}

\section{A.1 Samples}

Table A.1 - List of the countries

\begin{tabular}{|c|c|c|c|c|c|c|}
\hline \multirow{2}{*}{$\begin{array}{l}\text { Advanced } \\
\text { Australia }\end{array}$} & \multicolumn{2}{|c|}{ Emerging } & \multicolumn{4}{|c|}{ Developing } \\
\hline & Albania & Latvia & Afghanistan & Equatorial Guinea & Mauritius & Swaziland \\
\hline Austria & Algeria & Lebanon & Angola & Eritrea & Moldova & Syrian Arab Rep. \\
\hline Belgium & Argentina & Lithuania & Antigua \& Barbuda & Ethiopia & Mongolia & Tajikistan \\
\hline Canada & Armenia & Macedonia & Azerbaijan & Fiji & Montenegro & Tanzania \\
\hline Cyprus & Belarus & Malaysia & Bahamas & Gabon & Mozambique & Togo \\
\hline Denmark & Bermuda* & Mexico & Bahrain & Gambia & Myanmar & Tonga \\
\hline Finland & Bosnia \& Herzegovina & Morocco & Bangladesh & Ghana & Namibia & Trinidad \& Tobago \\
\hline France & Brazil & Pakistan & Barbados & Grenada & Nepal & Turkmenistan \\
\hline Germany & Bulgaria & Panama & Belize & Guinea & Nicaragua & Uganda \\
\hline Greece & Chile & Peru & Benin & Guinea-Bissau & Niger & United Arab Emirates \\
\hline Hong Kong & China & Philippines & Bhutan & Guyana & Nigeria & Uzbekistan \\
\hline Iceland & Colombia & Poland & Bolivia & Haiti & Oman & Vanuatu \\
\hline Ireland & Costa Rica & Romania & Botswana & Honduras & Palau* & Yemen \\
\hline Israel & Croatia & Russia & Brunei Darussalam & Iran & Papua New Guinea & Zambia \\
\hline Italy & Czech Rep. & Sebia Rep. & Burkina Faso & Iraq & Paraguay & Zimbabwe \\
\hline Japan & Dominican Rep. & Slovak Rep. & Burundi & Kenya & Qatar & \\
\hline Luxembourg & Ecuador & South Africa & Cambodia & Kiribati & Rwanda & \\
\hline Malta & Egypt & Sri Lanka & Cameroon & Kuwait & Sao Tomé \& Principe & \\
\hline Netherlands & El Salvador & Thailand & Cape Verde & Kyrgyz Rep. & Samoa & \\
\hline New Zealand & Estonia & Tunisia & Cayman Islands & Laos & Saudi Arabia & \\
\hline Norway & Georgia & Turkey & Central African Rep. & Lesotho & Senegal & \\
\hline Portugal & Guatemala & Ukraine & Chad & Liberia & Seychelles & \\
\hline Singapore & Hungary & Uruguay & Comoros & Libya & Sierra Leone & \\
\hline Slovenia & India & Venezuela & Congo, Dem. Rep & Madagascar & Solomon Islands & \\
\hline Spain & Indonesia & Vietnam & Congo Rep. & Malawi & Somalia* & \\
\hline Sweden & Jamaica & & Cote d'Ivoire & Maldives & St. Kitts \& Nevis & \\
\hline Switzerland & Jordan & & Cuba & Mali & St. Lucia & \\
\hline United Kingdom & Kazakhstan & & Djibouti & Marshall Islands & Sudan & \\
\hline United States & Korea & & Dominica & Mauritania & Suriname & \\
\hline
\end{tabular}

exchange rates for the mainland. New Caledonia and French Polynesia. These latter two territories are excluded from the database on equilibrium real exchange rates. 


\section{A.1.1. Geographical groupings: regions and sub-regions ${ }^{28}$}

\section{Africa}

\section{Eastern Africa}

Burundi, Comoros, Djibouti, Ethiopia, Kenya, Madagascar, Malawi, Mauritius, Mozambique, Rwanda, Somalia, Uganda, Tanzania, Zambia, Zimbabwe.

\section{Middle Africa}

Angola, Cameroon, Central African Republic, Chad, Congo D.R., Congo Rep., Equatorial Guinea, Gabon, Sao Tome and Principe.

\section{Northern Africa}

Algeria, Egypt, Libya, Morocco, Sudan, Tunisia.

\section{Southern Africa}

Botswana, Lesotho, Namibia, South Africa, Swaziland.

\section{Western Africa}

Benin, Burkina Faso, Cabo Verde, Cote d'Ivoire, Gambia, Ghana, Guinea, Guinea-Bissau, Liberia, Mali, Mauritania, Niger, Nigeria, Senegal, Sierra Leone, Togo.

\section{America}

\section{Caribbean}

Anguilla, Antigua and Barbuda, Aruba, Bahamas, Barbados, Cayman Islands, Cuba, Dominica, Dominican Rep., Grenada, Haiti, Jamaica, Saint Kitts and Nevis, Saint Lucia, Trinidad and Tobago.

\section{Central America}

Belize, Costa Rica, El Salvador, Guatemala, Honduras, Mexico, Nicaragua, Panama.

\section{South America}

Argentina, Bolivia, Brazil, Chile, Colombia, Ecuador, Paraguay, Peru, Suriname, Uruguay, Venezuela.

\section{Northern America}

Bermuda, Canada, United States of America.

\section{Asia}

\section{Central Asia}

Kazakhstan, Kyrgyzstan, Tajikistan, Turkmenistan, Uzbekistan.

\section{Eastern Asia}

\footnotetext{
${ }^{28}$ We used the online version of the United Nations publication "Standard Country or Area Codes for Statistical Use" originally published as Series M, No. 49 and now commonly referred to as the M49 standard. https://unstats.un.org/unsd/methods/m49/m49regin.htm (last access: 04/04/2017).
} 
China, China Hong Kong SAR, China, Japan, Korea Rep., Mongolia.

\section{Southern Asia}

Afghanistan, Bangladesh, Bhutan, India, Iran, Nepal, Pakistan, Sri Lanka.

\section{South-Eastern Asia}

Brunei Darussalam, Cambodia, Indonesia, Lao People's Dem. Rep., Malaysia, Myanmar, Philippines, Singapore, Thailand, Viet Nam.

\section{Western Asia}

Armenia, Azerbaijan, Bahrain, Cyprus, Georgia, Iraq, Israel, Jordan, Kuwait, Lebanon, Oman, Qatar, Saudi Arabia, Syria, Turkey, United Arab Emirates, Yemen.

\section{Europe}

\section{Eastern Europe}

Belarus, Bulgaria, Czechia, Hungary, Poland, Moldova Rep., Romania, Russian Federation, Slovakia, Ukraine.

\section{Northern Europe}

Denmark, Estonia, Finland, Ireland, Latvia, Lithuania, Norway, Sweden, United Kingdom.

\section{Southern Europe}

Albania, Bosnia and Herzegovina, Croatia, Greece, Italy, Malta, Montenegro, Portugal, Serbia, Slovenia, Spain, Macedonia (TFYR).

\section{Western Europe}

Austria, Belgium, France, Germany, Luxembourg, Netherlands, Switzerland.

\section{Oceania}

Australia, Fiji, New Zealand, Papua New Guinea, Solomon Islands, Vanuatu, Marshall Islands, Samoa, Tonga.

\section{A.1.2. Monetary unions}

\section{Common monetary area (CMA)}

Lesotho, Namibia, South Africa, Swaziland.

\section{CFA zone}

\section{Central African Economic and Monetary Community (CAEMC)}

Cameroon, Central African Republic, Chad, Republic of the Congo, Equatorial Guinea, Gabon.

West African Economic and Monetary Union (WAEMU) 
Burkina Faso, Cote d'Ivoire, Guinea-Bissau, Mali, Niger, Senegal, Togo.

\section{Eastern Caribbean Monetary Union (ECMU)}

Antigua and Barbuda, Dominica, Grenada, St. Kitts and Nevis, St. Lucia.

\section{Economic and Monetary Union (EMU)}

Austria, Belgium, Cyprus, Estonia, Finland, France, Germany, Greece, Ireland, Italy, Latvia, Lithuania, Luxembourg, Malta, the Netherlands, Portugal, Slovakia, Slovenia, Spain.

\section{A.2 Data: secondary sources}

Table A.2.1 - Nominal bilateral exchange rate (additional sources)

\begin{tabular}{lcllcc}
\hline Country & Period & Source & Country & Period & Source \\
\hline \hline Albania & $1970-1992$ & PWT9.0 & Moldova & $1990-1994$ & PWT9.0 \\
Armenia & $1990-1992$ & PWT9.0 & Mongolia & $1970-1990$ & PWT9.0 \\
Belarus & $1990-1994$ & PWT9.0 & Montenegro & $1990-1998$ & PWT9.0 \\
Bermuda & $1973-2015$ & PWT9.0 & Poland & $1960-1994$ & PWT9.0 \\
Bosnia \& Herzegovina & $1990-1996$ & PWT9.0 & Puerto Rico & $1973-2016$ & PWT9.0 \\
Cambodia & $1974-1989$ & PWT9.0 & Serbia & $1990-1996$ & PWT9.0 \\
Cayman Islands & $1973-2016$ & PWT9.0 & Somalia & $1990-2009$ & PWT 9.0 \\
Croatia & $1990-1991$ & PWT9.0 & Slovenia & 1990 & PWT9.0 \\
Ecuador & $1973-2015$ & PWT9.0 & Tajikistan & $1990-1991$ & PWT9.0 \\
Estonia & $1991-1992$ & PWT9.0 & Turkmenistan & $1990-2014$ & PWT9.0 \\
Georgia & $1990-1995$ & PWT9.0 & Ukraine & $1987-1992$ & PWT9.0 \\
Kazakhstan & $1990-1993$ & PWT9.0 & Vietnam & $1970-1985$ & PWT9.0 \\
Kyrgyz Republic & $1990-1993$ & PWT9.0 & Virgin Islands & $1973-2015$ & PWT9.0 \\
Macedonia, TFYR & $1990-1993$ & PWT9.0 & Yemen & $1973-1989$ & PWT9.0 \\
Mauritania & 2004 & PWT9.0 & & & \\
\hline Note : PWT 9.0 (Penn World Table 9.0 & http://www.rug.nl/ggdc/ (last access: 04/04/2017)).
\end{tabular}


Table A.2.2 - Consumer price index (additional sources)

\begin{tabular}{|c|c|c|c|c|c|}
\hline Country & Period & Source & Country & Period & Source \\
\hline Argentina & 2015 & INDEC & Lesotho & 1973-2014 & USDA \\
\hline Albania & 1973-1991 & USDA & Liberia & $1973-2000$ & USDA \\
\hline Armenia & 1973-1992 & USDA & Lithuania & 1973-1992 & USDA \\
\hline Bangladesh & 1973-1985 & USDA & Macedonia, TFYR & 1973-1992 & USDA \\
\hline Belarus & 1973-1992 & USDA & Malawi & 1973-1979 & USDA \\
\hline Belize & 1973-1979 & USDA & Mali & $1973-2014$ & USDA \\
\hline Bosnia \& Herzegovina & 1973-1993 & USDA & Mauritania & 1973-1984 & USDA \\
\hline Botswana & 1973 & USDA & Moldova Rep. & 1973-1993 & USDA \\
\hline Brazil & 1973-1979 & USDA & Mongolia & 1973-1991 & USDA \\
\hline Brunei & 1973-1976 & USDA & Mozambique & 1973-1986 & USDA \\
\hline Cayman Islands & $1985-2015$ & $\mathrm{CIG} / \mathrm{ESO}$ & Namibia & $1973-2002$ & USDA \\
\hline Cambodia & 1973-1993 & USDA & New Caledonia & $1985-2016$ & ILS $^{a} ;$ ISEE $^{b}$ \\
\hline Central African Rep. & 1973-1979 & USDA & Oman & $1973-2014$ & USDA \\
\hline Chad & 1973-1982 & USDA & Qatar & 1973-1978 & USDA \\
\hline Chile & $1973-2008$ & USDA & Romania & 1973-1990 & USDA \\
\hline China & 1973-1979 & USDA & Russian Federation & 1973-1991 & USDA \\
\hline China, Hong Kong & $1973-1980$ & USDA & Rwanda & 1994 & USDA \\
\hline Comoros & $1973-1980$ & USDA & Saint Kitts and Nevis & 1973-1978 & USDA \\
\hline Congo & 1973-1984 & USDA & Sao Tome\& Principe & 1973-1995 & USDA \\
\hline Croatia & 1973-1984 & USDA & Sierra Leone & 1973-2005 & USDA \\
\hline Czechia & 1973-1991 & USDA & Slovakia & 1973-1992 & USDA \\
\hline Djibouti & 1973-1999 & USDA & Tajikistan & $1973-2014$ & USDA \\
\hline Equatorial Guinea & 1973-1984 & USDA & Slovenia & 1973-1991 & USDA \\
\hline Estonia & 1973-1991 & USDA & Tonga & 1973-1975 & USDA \\
\hline French Polynesia & $1973-2016$ & ISPF & Tunisia & 1973-1982 & USDA \\
\hline Georgia & 1973-1991 & USDA & Turkmenistan & $1973-2014$ & USDA \\
\hline Grenada & 1973-1975 & USDA & Uganda & 1973-1991 & USDA \\
\hline Guinea & 1973-2005 & USDA & Ukraine & 1973-1991 & USDA \\
\hline Guinea Bissau & 1973-1986 & USDA & United Arab Emirates & 1973-2014 & USDA \\
\hline Guyana & 1973-1993 & USDA & United Kingdom & 1973-1987 & USDA \\
\hline Kazakhstan & 1983-1995 & USDA & Venezuela & $1973-2014$ & USDA \\
\hline Kiribati & 1980-2015 & USDA & Uzbekistan & 1973-2015 & USDA $^{d}$ \\
\hline Kyrgyzstan & 1973-1993 & USDA & Vietnam & 1973-1979 & USDA \\
\hline Lao PDR & 1973-1987 & USDA & Yemen & $1973-1980$ & USDA \\
\hline Latvia & 1973-1990 & USDA & Zambia & 1973-1984 & USDA \\
\hline Lebanon & 1973-2011 & USDA $^{c}$ & Zimbabwe & 1973-2014 & USDA \\
\hline
\end{tabular}

Notes: a: 1985-1992; b: 1993-2016; c: the 1973-2007 period and 2011; d: the 1973-1991 and 2012-2015 periods.

CIG/ESO: Cayman Islands government, Economics and Statistics Office | http://www.eso.ky/

ILS: International Labor of Statistics | http://www.ilo.org/ilostat

INDEC: Instituto Nacional de Estadística y Censos de Argentina | http://www.indec.gov.ar/

ISEE: Institut de la Statistique et des Etudes Economiques Nouvelle-Calédonie | http://www.isee.nc/

ISPF: Institut statistique de Polynésie Française | http://www.ispf.pf/

USDA: United States Department of Agriculture | https://www.ers.usda.gov/

Last access for all the secondary online sources: 04/04/2017. 
Table A.2.3 - Real GDP per capita in PPP terms (additional sources)

\begin{tabular}{lcclcc}
\hline Country & Period & Source & Country & Period & Source \\
\hline \hline Afghanistan & $1980-2001$ & WEO, WDI & Papua New-Guinea & $1980-2016$ & WEO \\
Aruba & 2011 & WDI & Palau & $1991-2015$ & WDI \\
Bermuda & $1990-2013$ & WDI & Russian Federation & $1990-1991$ & WDI \\
Cayman Islands & 2013 & WDI & Samoa & $1980-2016$ & WEO, WDI \\
Cuba & $1990-2013$ & WDI & Serbia & $1995-2015$ & WDI \\
Guyana & $1980-2016$ & WEO & Slovakia & 1992 & WDI \\
Iraq & $1990-2015$ & WDI & Solomon Islands & $1980-2016$ & WEO \\
Kiribati & $1980-2016$ & WEO & Tonga & $1980-2016$ & WEO \\
Liberia & $1998-1999$ & WDI & Uzbekistan & $1990-1992$ & WDI \\
Marshall Islands & $1990-2016$ & WEO, WDI & Vanuatu & $1980-2016$ & WEO \\
Myanmar & $1990-1997$ & WDI & Zimbabwe & $1990-1997$ & WDI \\
Nicaragua & $1990-1993$ & WDI & & & \\
\hline
\end{tabular}

Note: WDI: World Development indicators (World Bank); WEO: World Economic Outlook (International Monetary Fund).

Table A.2.4 - Terms of trade (additional sources)

\begin{tabular}{|c|c|c|c|c|c|}
\hline Country & Period & Source & Country & Period & Source \\
\hline Australia & $1973-2015 / 16$ & OECD/EIKON & Lithuania & 2016 & ElKON \\
\hline Austria & $1973-2015 / 16$ & OECD/EIKON & Luxembourg & $1973-2015 / 16$ & OECD/EIKON \\
\hline Brazil & 2016 & EIKON & Mexico & $1973-2015 / 16$ & OECD/EIKON \\
\hline Belgium & $1973-2015 / 16$ & OECD/EIKON & Netherlands & $1973-2015 / 16$ & OECD/EIKON \\
\hline Canada & $1973-2015 / 16$ & OECD/EIKON & New Zealand & $1973-2015 / 16$ & OECD/EIKON \\
\hline China & 2016 & EIKON & Norway & $1973-2015 / 16$ & OECD/EIKON \\
\hline Colombia & 1973-1979 & EIKON & Pakistan & 2016 & EIKON \\
\hline Denmark & $1973-2015 / 16$ & OECD/EIKON & Peru & 2016 & EIKON \\
\hline Ecuador & 2016 & EIKON & Poland & $1990-2015 / 16$ & OECD/EIKON \\
\hline El Salvador & 2016 & EIKON & Portugal & $1973-2015 / 16$ & OECD/EIKON \\
\hline Estonia & $1993-2015 / 16$ & OECD/EIKON & Russia & 1995-2015 & OECD \\
\hline Finland & $1973-2015 / 16$ & OECD/EIKON & Serbia & 2016 & EIKON \\
\hline France & $1973-2015 / 16$ & OECD/EIKON & Singapore & 2016 & EIKON \\
\hline Germany & $1973-2015 / 16$ & OECD/EIKON & Slovenia & $1990-2015$ & OECD \\
\hline Greece & $1973-2015 / 16$ & OECD/EIKON & Slovakia & $1992-2015 / 16$ & OECD/EIKON \\
\hline Hong Kong & 2016 & EIKON & South Africa & $1973-2015 / 16$ & OECD/EIKON \\
\hline Hungary & $1991-2015 / 16$ & OECD/EIKON & Spain & $1973-2015 / 16$ & OECD/EIKON \\
\hline Indonesia & 2016 & EIKON & Sri Lanka & 2016 & EIKON \\
\hline Ireland & $1973-2015 / 16$ & OECD/EIKON & Sweden & $1973-2015$ & OECD \\
\hline Island & 1973-2015 & OECD & Switzerland & $1973-2015 / 16$ & OECD/EIKON \\
\hline Israel & 2016 & EIKON & Thailand & 2016 & EIKON \\
\hline Italy & $1973-2015 / 16$ & EIKON & Turkey & $1973-2015 / 16$ & OECD/EIKON \\
\hline Japan & $1973-2015 / 16$ & OECD/EIKON & United Kingdom & $1973-2015 / 16$ & EIKON \\
\hline Jordan & 2016 & EIKON & Ukraine & 2016 & EIKON \\
\hline Korea & $1973-2015 / 16$ & OECD/EIKON & United States & $1973-2015 / 16$ & EIKON \\
\hline Latvia & $1995-2015 / 16$ & OECD/EIKON & & & \\
\hline
\end{tabular}

\section{A.3 The data: comparisons of the effective exchange rates}


Table A.3.1 - Correlation matrix (NEERs)

\begin{tabular}{|c|c|c|c|c|c|c|c|c|c|c|c|}
\hline & & \multirow[b]{3}{*}{$\mathrm{Nb}$. } & \multirow{3}{*}{$\begin{array}{l}\text { IMF } \\
100 \\
\end{array}$} & \multirow{2}{*}{\multicolumn{2}{|c|}{ Bruegel }} & \multicolumn{6}{|c|}{ CEPII } \\
\hline & & & & & & \multicolumn{2}{|c|}{$\begin{array}{c}\text { Fixed } \\
(1973-2016)\end{array}$} & \multicolumn{2}{|c|}{$\begin{array}{c}\text { Fixed } \\
(2008-2012)\end{array}$} & \multicolumn{2}{|c|}{$\begin{array}{c}\text { Time-varying } \\
\text { (5-years) }\end{array}$} \\
\hline & & & & 67 & 172 & 30 & 186 & 30 & 186 & 30 & 186 \\
\hline IMF & & 100 & 1.0000 & & & & & & & & \\
\hline \multirow{2}{*}{ Bruegel } & & 67 & 0.9995 & 1.0000 & & & & & & & \\
\hline & & 172 & 0.9994 & 1.0000 & 1.0000 & & & & & & \\
\hline \multirow{6}{*}{ CEPII } & Fixed & 30 & 0.9992 & 1.0000 & 1.0000 & 1.0000 & & & & & \\
\hline & (1973-2016) & 186 & 0.9992 & 1.0000 & 1.0000 & 1.0000 & 1.0000 & & & & \\
\hline & Fixed & 30 & 0.9992 & 1.0000 & 1.0000 & 1.0000 & 1.0000 & 1.0000 & & & \\
\hline & $(2008-2012)$ & 186 & 0.9992 & 1.0000 & 1.0000 & 1.0000 & 1.0000 & 1.0000 & 1.0000 & & \\
\hline & Time-varying & 30 & 0.9992 & 1.0000 & 1.0000 & 1.0000 & 1.0000 & 1.0000 & 1.0000 & 1.0000 & \\
\hline & (5-years) & 186 & 0.9992 & 1.0000 & 1.0000 & 1.0000 & 1.0000 & 1.0000 & 1.0000 & 1.0000 & 1.0000 \\
\hline
\end{tabular}

Table A.3.2 - Correlation matrix (REERs)

\begin{tabular}{|c|c|c|c|c|c|c|c|c|c|c|c|c|}
\hline & & \multirow[b]{3}{*}{ Nb. } & \multirow{3}{*}{$\begin{array}{l}\text { IMF } \\
100\end{array}$} & \multirow{3}{*}{$\begin{array}{l}\text { WB } \\
108\end{array}$} & \multirow{2}{*}{\multicolumn{2}{|c|}{ Bruegel }} & \multicolumn{6}{|c|}{ CEPII } \\
\hline & & & & & & & \multicolumn{2}{|c|}{$\begin{array}{c}\text { Fixed } \\
(1973-2016)\end{array}$} & \multicolumn{2}{|c|}{$\begin{array}{c}\text { Fixed } \\
(2008-2012)\end{array}$} & \multicolumn{2}{|c|}{$\begin{array}{c}\text { Time-varying } \\
\text { (5-years) }\end{array}$} \\
\hline & & & & & 67 & 172 & 30 & 186 & 30 & 186 & 30 & 186 \\
\hline IMF & & 100 & 1.0000 & & & & & & & & & \\
\hline WB & & 108 & 0.9970 & 1.0000 & & & & & & & & \\
\hline \multirow{2}{*}{ Bruegel } & & 67 & 0.5144 & 0.5172 & 1.0000 & & & & & & & \\
\hline & & 172 & 0.4503 & 0.4517 & 0.9896 & 1.0000 & & & & & & \\
\hline \multirow{6}{*}{ CEPII } & Fixed & 30 & 0.4858 & 0.4858 & 0.6944 & 0.6925 & 1.0000 & & & & & \\
\hline & $(1973-2016)$ & 186 & 0.5050 & 0.5052 & 0.7363 & 0.7354 & 0.9969 & 1.0000 & & & & \\
\hline & Fixed & 30 & 0.5670 & 0.5666 & 0.8115 & 0.8108 & 0.9544 & 0.9670 & 1.0000 & & & \\
\hline & $(2008-2012)$ & 186 & 0.5739 & 0.5739 & 0.8373 & 0.8376 & 0.9428 & 0.9605 & 0.9974 & 1.0000 & & \\
\hline & Time-varying & 30 & 0.4276 & 0.4276 & 0.6130 & 0.6112 & 0.9703 & 0.9598 & 0.9009 & 0.8844 & 1.0000 & \\
\hline & (5-years) & 186 & 0.4596 & 0.4598 & 0.6633 & 0.6617 & 0.9785 & 0.9742 & 0.9252 & 0.9136 & 0.9963 & 1.0000 \\
\hline
\end{tabular}

Note: correlations based on 2402 observations. Nb. (in both lines and columns) indicates the number of considered trade partners. 


\section{B. The estimations}

\section{B.1. Estimations (186 trade partners)}

Table B.1 - Equilibrium exchange rate model estimations (all countries)

\begin{tabular}{|c|c|c|c|c|c|c|c|c|c|}
\hline \multirow{2}{*}{$\begin{array}{c}\text { Weighting } \\
\text { system }\end{array}$} & \multicolumn{6}{|c|}{ Fixed } & \multirow{2}{*}{\multicolumn{3}{|c|}{$\begin{array}{c}\text { Time-varying weights } \\
\text { (5-year averages) }\end{array}$}} \\
\hline & \multicolumn{3}{|c|}{$(1973-2016)$} & \multicolumn{3}{|c|}{$(2008-2012)$} & & & \\
\hline \multicolumn{10}{|c|}{ Long-run dynamics } \\
\hline$B S$ & $\begin{array}{l}0.327^{* * *} \\
(0.0222)\end{array}$ & $\begin{array}{c}0.431 * * * \\
(0.0268)\end{array}$ & $\begin{array}{c}0.0771^{* * *} \\
(0.0227)\end{array}$ & $\begin{array}{l}0.276^{* * *} \\
(0.0204)\end{array}$ & $\begin{array}{c}0.249 * * * \\
(0.0229)\end{array}$ & $\begin{array}{l}-0.0238 \\
(0.0210)\end{array}$ & $\begin{array}{l}0.368^{* * *} \\
(0.0215)\end{array}$ & $\begin{array}{l}0.409 * * * \\
(0.0218)\end{array}$ & $\begin{array}{c}0.0740^{* * *} \\
(0.0209)\end{array}$ \\
\hline$N F A$ & & $\begin{array}{c}0.166 * * * \\
(0.0145)\end{array}$ & $\begin{array}{c}0.0466 * * * \\
(0.00616)\end{array}$ & & $\begin{array}{c}0.177 * * * \\
(0.0135)\end{array}$ & $\begin{array}{c}0.0431 * * * \\
(0.00580)\end{array}$ & & $\begin{array}{l}0.163 * * * \\
(0.0150)\end{array}$ & $\begin{array}{c}0.0432 * * * \\
(0.00569)\end{array}$ \\
\hline TOT & & & $\begin{array}{c}0.402 * * * \\
(0.0309)\end{array}$ & & & $\begin{array}{c}0.480 * * * \\
(0.0308)\end{array}$ & & & $\begin{array}{c}0.419 * * * \\
(0.0307)\end{array}$ \\
\hline \multicolumn{10}{|c|}{ Short-run dynamics } \\
\hline e.c. & $\begin{array}{c}-0.182^{* * *} \\
(0.0173)\end{array}$ & $\begin{array}{c}-0.146 * * * \\
(0.0142)\end{array}$ & $\begin{array}{c}-0.179 * * * \\
(0.0150)\end{array}$ & $\begin{array}{c}-0.184^{* * *} \\
(0.0166)\end{array}$ & $\begin{array}{c}-0.155^{* * *} \\
(0.0141)\end{array}$ & $\begin{array}{c}-0.181^{* * *} \\
(0.0167)\end{array}$ & $\begin{array}{c}-0.182 * * * \\
(0.0183)\end{array}$ & $\begin{array}{c}-0.148^{* * *} \\
(0.0146)\end{array}$ & $\begin{array}{c}-0.185^{* * *} \\
(0.0165)\end{array}$ \\
\hline$D . B S$ & $\begin{array}{c}0.199 \\
(0.123)\end{array}$ & $\begin{array}{c}0.130 \\
(0.125)\end{array}$ & $\begin{array}{c}0.151 \\
(0.151)\end{array}$ & $\begin{array}{l}0.212^{*} \\
(0.114)\end{array}$ & $\begin{array}{c}0.159 \\
(0.121)\end{array}$ & $\begin{array}{c}0.175 \\
(0.140)\end{array}$ & $\begin{array}{l}0.222^{* *} \\
(0.103)\end{array}$ & $\begin{array}{c}0.176 \\
(0.115)\end{array}$ & $\begin{array}{c}0.189 \\
(0.123)\end{array}$ \\
\hline D.NFA & & $\begin{array}{c}0.0124 \\
(0.0412)\end{array}$ & $\begin{array}{c}0.0573^{* * *} \\
(0.0211)\end{array}$ & & $\begin{array}{r}-0.00408 \\
(0.0506)\end{array}$ & $\begin{array}{l}0.0521^{* *} \\
(0.0205)\end{array}$ & & $\begin{array}{l}0.00643 \\
(0.0413)\end{array}$ & $\begin{array}{l}0.0553^{* *} \\
(0.0237)\end{array}$ \\
\hline D.TOT & & & $\begin{array}{c}0.0871 \\
(0.111)\end{array}$ & & & $\begin{array}{l}0.0906 \\
(0.116)\end{array}$ & & & $\begin{array}{c}0.121 \\
(0.185)\end{array}$ \\
\hline Constant & $\begin{array}{l}0.908^{* * *} \\
(0.0834)\end{array}$ & $\begin{array}{l}0.770 * * * \\
(0.0719)\end{array}$ & $\begin{array}{l}0.514 * * * \\
(0.0429)\end{array}$ & $\begin{array}{l}0.908^{* * *} \\
(0.0790)\end{array}$ & $\begin{array}{l}0.784 * * * \\
(0.0689)\end{array}$ & $\begin{array}{l}0.437 * * * \\
(0.0399)\end{array}$ & $\begin{array}{l}0.914 * * * \\
(0.0890)\end{array}$ & $\begin{array}{l}0.775^{* * *} \\
(0.0738)\end{array}$ & $\begin{array}{r}0.518^{* * *} \\
(0.0459)\end{array}$ \\
\hline
\end{tabular}

Note: Standard errors are in parentheses. ${ }^{* * *} p<0.01,{ }^{* *} p<0.05,{ }^{*} p<0.1$. "e.c." denotes the error-correction term. 


\section{B.1.1. Development levels}

Table B.1.1.1 - Equilibrium exchange rate model estimations (advanced economies)

\begin{tabular}{|c|c|c|c|c|c|c|c|c|c|}
\hline \multirow{3}{*}{$\begin{array}{l}\begin{array}{c}\text { Weighting } \\
\text { system }\end{array} \\
\text { Model }\end{array}$} & \multicolumn{6}{|c|}{ Fixed } & \multirow{2}{*}{\multicolumn{3}{|c|}{$\begin{array}{c}\text { Time-varying weights } \\
\text { (5-year averages) }\end{array}$}} \\
\hline & \multicolumn{3}{|c|}{$(1973-2016)$} & \multicolumn{3}{|c|}{$(2008-2012)$} & & & \\
\hline & (1) & $(2)$ & (3) & (1) & $(2)$ & (3) & (1) & $(2)$ & (3) \\
\hline \multicolumn{10}{|c|}{ Long-run dynamics } \\
\hline$B S$ & $\begin{array}{l}0.0911^{*} \\
(0.0486)\end{array}$ & $\begin{array}{l}-0.0490 \\
(0.0365)\end{array}$ & $\begin{array}{c}-0.0639 * * \\
(0.0313)\end{array}$ & $\begin{array}{l}-0.0127 \\
(0.0363)\end{array}$ & $\begin{array}{c}-0.173 * * * \\
(0.0295)\end{array}$ & $\begin{array}{c}-0.0801^{* * *} \\
(0.0242)\end{array}$ & $\begin{array}{c}0.605^{* * *} \\
(0.115)\end{array}$ & $\begin{array}{c}-0.299 * * * \\
(0.0553)\end{array}$ & $\begin{array}{c}0.0481 \\
(0.0526)\end{array}$ \\
\hline$N F A$ & & $\begin{array}{l}0.0469 * * * \\
(0.00739)\end{array}$ & $\begin{array}{c}0.0159 * \\
(0.00944)\end{array}$ & & $\begin{array}{l}0.0589 * * * \\
(0.00916)\end{array}$ & $\begin{array}{c}0.0266 * * \\
(0.0110)\end{array}$ & & $\begin{array}{l}-0.0211 \\
(0.0137)\end{array}$ & $\begin{array}{c}0.0176^{*} \\
(0.00978)\end{array}$ \\
\hline TOT & & & $\begin{array}{l}1.028 * * * \\
(0.0785)\end{array}$ & & & $\begin{array}{l}0.833 * * * \\
(0.0923)\end{array}$ & & & $\begin{array}{l}1.018^{* * *} \\
(0.0747)\end{array}$ \\
\hline \multicolumn{10}{|c|}{ Short-run dynamics } \\
\hline e.c. & $\begin{array}{c}-0.160 * * * \\
(0.0352)\end{array}$ & $\begin{array}{c}-0.164 * * * \\
(0.0300)\end{array}$ & $\begin{array}{c}-0.204 * * * \\
(0.0335)\end{array}$ & $\begin{array}{c}-0.147^{* * *} \\
(0.0255)\end{array}$ & $\begin{array}{c}-0.166 * * * \\
(0.0293)\end{array}$ & $\begin{array}{c}-0.190 * * * \\
(0.0306)\end{array}$ & $\begin{array}{c}-0.153^{* * *} \\
(0.0455)\end{array}$ & $\begin{array}{c}-0.153 * * * \\
(0.0334)\end{array}$ & $\begin{array}{c}-0.189 * * * \\
(0.0347)\end{array}$ \\
\hline$D . B S$ & $\begin{array}{l}-0.0414 \\
(0.0638)\end{array}$ & $\begin{array}{l}-0.0353 \\
(0.0691)\end{array}$ & $\begin{array}{l}-0.122 * * \\
(0.0591)\end{array}$ & $\begin{array}{c}0.0264 \\
(0.0652)\end{array}$ & $\begin{array}{l}-0.0117 \\
(0.0447)\end{array}$ & $\begin{array}{c}-0.0817^{* *} \\
(0.0395)\end{array}$ & $\begin{array}{l}-0.0536 \\
(0.0540)\end{array}$ & $\begin{array}{c}0.0511 \\
(0.0486)\end{array}$ & $\begin{array}{l}-0.0705^{*} \\
(0.0392)\end{array}$ \\
\hline$D . N F A$ & & $\begin{array}{l}-0.0371 \\
(0.0524)\end{array}$ & $\begin{array}{l}-0.0719 \\
(0.0451)\end{array}$ & & $\begin{array}{l}-0.0399 \\
(0.0502)\end{array}$ & $\begin{array}{r}-0.0798 * \\
(0.0461)\end{array}$ & & $\begin{array}{l}-0.0260 \\
(0.0548)\end{array}$ & $\begin{array}{l}-0.0671 \\
(0.0460)\end{array}$ \\
\hline D.TOT & & & $\begin{array}{l}0.347^{* * *} \\
(0.0960)\end{array}$ & & & $\begin{array}{l}0.378 * * * \\
(0.0910)\end{array}$ & & & $\begin{array}{l}0.334 * * * \\
(0.0904)\end{array}$ \\
\hline Constant & $\begin{array}{c}0.732^{* * *} \\
(0.161)\end{array}$ & $\begin{array}{c}0.764^{* * *} \\
(0.142)\end{array}$ & $\begin{array}{l}-0.020 * * * \\
(0.00554)\end{array}$ & $\begin{array}{c}0.677^{* * *} \\
(0.117)\end{array}$ & $\begin{array}{c}0.783^{* * *} * \\
(0.138)\end{array}$ & $\begin{array}{c}0.155^{* * *} \\
(0.0239)\end{array}$ & $\begin{array}{c}0.681^{* * *} \\
(0.209)\end{array}$ & $\begin{array}{c}0.716^{* * *} \\
(0.156)\end{array}$ & $\begin{array}{c}-0.0134 * * * \\
(0.00414)\end{array}$ \\
\hline
\end{tabular}

Note: Standard errors are in parentheses. ${ }^{* * *} p<0.01,{ }^{* *} p<0.05, * p<0.1$. "e.c." denotes the error-correction term. 
Table B.1.1.2 - Equilibrium exchange rate model estimations (emerging economies)

\begin{tabular}{|c|c|c|c|c|c|c|c|c|c|}
\hline \multirow{2}{*}{$\begin{array}{l}\begin{array}{c}\text { Weighting } \\
\text { system }\end{array} \\
\text { Model }\end{array}$} & \multicolumn{6}{|c|}{ Fixed } & \multicolumn{3}{|c|}{$\begin{array}{c}\text { Time-varying weights } \\
\text { (5-year averages) }\end{array}$} \\
\hline & (1) & $(2)$ & (3) & (1) & (2) & (3) & (1) & (2) & (3) \\
\hline \multicolumn{10}{|c|}{ Long-run dynamics } \\
\hline$B S$ & $\begin{array}{c}0.380 * * * \\
(0.0403)\end{array}$ & $\begin{array}{c}0.735^{* * *} \\
(0.0440)\end{array}$ & $\begin{array}{l}-0.0438 \\
(0.0352)\end{array}$ & $\begin{array}{c}0.278 * * * \\
(0.0398)\end{array}$ & $\begin{array}{c}0.630 * * * \\
(0.0542)\end{array}$ & $\begin{array}{c}-0.0965^{* *} \\
(0.0379)\end{array}$ & $\begin{array}{c}0.336 * * * \\
(0.0354)\end{array}$ & $\begin{array}{c}0.478 * * * \\
(0.0325)\end{array}$ & $\begin{array}{l}-0.0184 \\
(0.0208)\end{array}$ \\
\hline$N F A$ & & $\begin{array}{l}0.183 * * * \\
(0.0383)\end{array}$ & $\begin{array}{c}0.0111 \\
(0.0283)\end{array}$ & & $\begin{array}{l}0.150 * * * \\
(0.0339)\end{array}$ & $\begin{array}{c}0.0158 \\
(0.0264)\end{array}$ & & $\begin{array}{l}0.227^{* * *} \\
(0.0358)\end{array}$ & $\begin{array}{l}0.132 * * * \\
(0.0236)\end{array}$ \\
\hline TOT & & & $\begin{array}{l}0.232 * * * \\
(0.0312)\end{array}$ & & & $\begin{array}{c}0.336 * * * \\
(0.0363)\end{array}$ & & & $\begin{array}{c}0.208 * * * \\
(0.0289)\end{array}$ \\
\hline \multicolumn{10}{|c|}{ Short-run dynamics } \\
\hline e.c. & $\begin{array}{c}-0.210 * * * \\
(0.0390)\end{array}$ & $\begin{array}{c}-0.190 * * * \\
(0.0367)\end{array}$ & $\begin{array}{c}-0.194 * * * \\
(0.0333)\end{array}$ & $\begin{array}{c}-0.221^{* * *} \\
(0.0377)\end{array}$ & $\begin{array}{c}-0.197^{* * *} \\
(0.0364)\end{array}$ & $\begin{array}{c}-0.200 * * * \\
(0.0358)\end{array}$ & $\begin{array}{c}-0.207^{* * *} \\
(0.0404)\end{array}$ & $\begin{array}{c}-0.189 * * * \\
(0.0371)\end{array}$ & $\begin{array}{c}-0.211^{* * *} \\
(0.0380)\end{array}$ \\
\hline$D . B S$ & $\begin{array}{l}0.511^{* *} \\
(0.259)\end{array}$ & $\begin{array}{c}0.324 \\
(0.210)\end{array}$ & $\begin{array}{l}0.223 * * * \\
(0.0753)\end{array}$ & $\begin{array}{l}0.453^{*} \\
(0.241)\end{array}$ & $\begin{array}{c}0.332 \\
(0.240)\end{array}$ & $\begin{array}{l}0.162 * * \\
(0.0758)\end{array}$ & $\begin{array}{l}0.478 * * \\
(0.195)\end{array}$ & $\begin{array}{l}0.327^{*} \\
(0.171)\end{array}$ & $\begin{array}{l}0.236 * * * \\
(0.0618)\end{array}$ \\
\hline$D . N F A$ & & $\begin{array}{r}-0.0248 \\
(0.115)\end{array}$ & $\begin{array}{l}0.133 * * * \\
(0.0380)\end{array}$ & & $\begin{array}{r}-0.0517 \\
(0.156)\end{array}$ & $\begin{array}{l}0.134^{* * *} \\
(0.0375)\end{array}$ & & $\begin{array}{r}-0.0397 \\
(0.110)\end{array}$ & $\begin{array}{c}0.0913 * * \\
(0.0396)\end{array}$ \\
\hline D.TOT & & & $\begin{array}{l}-0.0717 \\
(0.0588)\end{array}$ & & & $\begin{array}{c}-0.104 \\
(0.0665)\end{array}$ & & & $\begin{array}{c}-0.131 \\
(0.0804)\end{array}$ \\
\hline Constant & $\begin{array}{c}1.012^{* * *} \\
(0.185)\end{array}$ & $\begin{array}{c}0.994^{* * * *} \\
(0.187)\end{array}$ & $\begin{array}{c}0.675^{* * *} \\
(0.118)\end{array}$ & $\begin{array}{c}1.046 * * * \\
(0.176)\end{array}$ & $\begin{array}{c}1.003^{* * *} * \\
(0.180)\end{array}$ & $\begin{array}{c}0.597^{* * *} * \\
(0.109)\end{array}$ & $\begin{array}{c}0.990 * * * \\
(0.192)\end{array}$ & $\begin{array}{c}0.960 * * * \\
(0.184)\end{array}$ & $\begin{array}{c}0.773^{* * *} \\
(0.143)\end{array}$ \\
\hline
\end{tabular}

Note: Standard errors are in parentheses. ${ }^{* * *} \mathrm{p}<0.01,{ }^{* *} \mathrm{p}<0.05,{ }^{*} \mathrm{p}<0.1$. "e.c." denotes the error-correction term. 
Table B.1.1.3 - Equilibrium exchange rate model estimations (developing countries)

\begin{tabular}{|c|c|c|c|c|c|c|c|c|c|}
\hline $\begin{array}{c}\begin{array}{c}\text { Weighting } \\
\text { system }\end{array} \\
\text { Model }\end{array}$ & (1) & (2) & (3) & (1) & $(2)$ & (3) & (1) & (2) & $(3)$ \\
\hline \multicolumn{10}{|c|}{ Long-run dynamics } \\
\hline$B S$ & $\begin{array}{l}0.390 * * * \\
(0.0288)\end{array}$ & $\begin{array}{l}0.258 * * * \\
(0.0310)\end{array}$ & $\begin{array}{c}0.727^{* * *} \\
(0.0343)\end{array}$ & $\begin{array}{l}0.327 * * * \\
(0.0252)\end{array}$ & $\begin{array}{c}0.154 * * * \\
(0.0262)\end{array}$ & $\begin{array}{c}0.244 * * * \\
(0.0297)\end{array}$ & $\begin{array}{c}0.406 * * * \\
(0.0285)\end{array}$ & $\begin{array}{l}0.102^{* * *} \\
(0.0141)\end{array}$ & $\begin{array}{c}0.226 * * * \\
(0.0232)\end{array}$ \\
\hline NFA & & $\begin{array}{c}0.211^{* * *} \\
(0.0185)\end{array}$ & $\begin{array}{c}0.0910 * * * \\
(0.0132)\end{array}$ & & $\begin{array}{c}0.257^{* * *} * \\
(0.0202)\end{array}$ & $\begin{array}{c}0.0456 * * * \\
(0.00802)\end{array}$ & & $\begin{array}{c}0.191^{* * *} * \\
(0.0172)\end{array}$ & $\begin{array}{l}0.116^{* * *} \\
(0.00836)\end{array}$ \\
\hline TOT & & & $\begin{array}{c}0.113 * * * \\
(0.0419)\end{array}$ & & & $\begin{array}{c}0.266 * * * \\
(0.0334)\end{array}$ & & & $\begin{array}{c}-0.166 * * * \\
(0.0317)\end{array}$ \\
\hline \multicolumn{10}{|c|}{ Short-run dynamics } \\
\hline e.c. & $\begin{array}{c}-0.179 * * * \\
(0.0216)\end{array}$ & $\begin{array}{c}-0.140 * * * \\
(0.0153)\end{array}$ & $\begin{array}{c}-0.150^{* * *} \\
(0.0194)\end{array}$ & $\begin{array}{c}-0.185^{* * *} \\
(0.0210)\end{array}$ & $\begin{array}{c}-0.147^{* * *} \\
(0.0155)\end{array}$ & $\begin{array}{c}-0.192 * * * \\
(0.0230)\end{array}$ & $\begin{array}{c}-0.172^{* * *} \\
(0.0225)\end{array}$ & $\begin{array}{c}-0.149 * * * \\
(0.0166)\end{array}$ & $\begin{array}{c}-0.172^{* * *} \\
(0.0176)\end{array}$ \\
\hline$D . B S$ & $\begin{array}{l}0.0988 \\
(0.175)\end{array}$ & $\begin{array}{l}0.0700 \\
(0.198)\end{array}$ & $\begin{array}{c}0.141 \\
(0.277)\end{array}$ & $\begin{array}{c}0.138 \\
(0.163)\end{array}$ & $\begin{array}{c}0.115 \\
(0.181)\end{array}$ & $\begin{array}{c}0.237 \\
(0.257)\end{array}$ & $\begin{array}{c}0.159 \\
(0.155)\end{array}$ & $\begin{array}{c}0.159 \\
(0.190)\end{array}$ & $\begin{array}{c}0.222 \\
(0.225)\end{array}$ \\
\hline D.NFA & & $\begin{array}{c}0.0332 \\
(0.0426)\end{array}$ & $\begin{array}{c}0.0736 * * \\
(0.0294)\end{array}$ & & $\begin{array}{c}0.0186 \\
(0.0417)\end{array}$ & $\begin{array}{c}0.0531^{* *} \\
(0.0265)\end{array}$ & & $\begin{array}{c}0.0338 \\
(0.0453)\end{array}$ & $\begin{array}{c}0.0490 \\
(0.0336)\end{array}$ \\
\hline D.TOT & & & $\begin{array}{c}0.126 \\
(0.203)\end{array}$ & & & $\begin{array}{c}0.128 \\
(0.211)\end{array}$ & & & $\begin{array}{c}0.272 \\
(0.340)\end{array}$ \\
\hline Constant & $\begin{array}{c}0.949 * * * \\
(0.108)\end{array}$ & $\begin{array}{c}0.753^{* * *} \\
(0.0799)\end{array}$ & $\begin{array}{c}0.789^{* * *} \\
(0.102)\end{array}$ & $\begin{array}{c}0.963^{* * *} \\
(0.104)\end{array}$ & $\begin{array}{c}0.764^{* * *} \\
(0.0783)\end{array}$ & $\begin{array}{c}0.725^{* * *} \\
(0.0852)\end{array}$ & $\begin{array}{c}0.924^{* * *} \\
(0.114)\end{array}$ & $\begin{array}{c}0.762^{* * *} \\
(0.0834)\end{array}$ & $\begin{array}{c}1.005^{* * *} \\
(0.0994)\end{array}$ \\
\hline
\end{tabular}

Note: Standard errors are in parentheses. ${ }^{* * *} p<0.01,{ }^{*} p<0.05,{ }^{*} p<0.1$. "e.c." denotes the error-correction term. 
B.1.2. Monetary unions

Table B.1.2.1 - Equilibrium exchange rate model estimations (CAEMC)

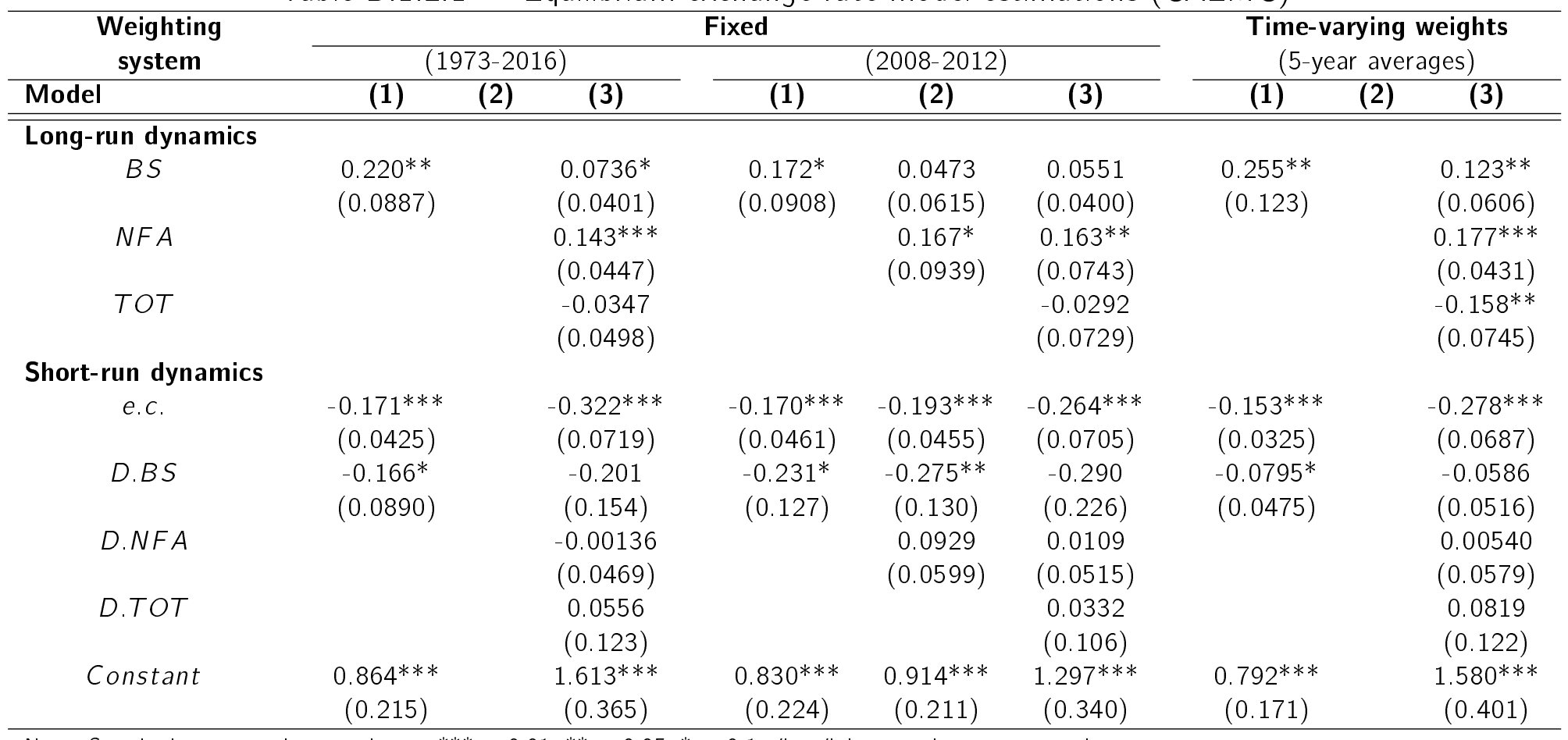

Note: Standard errors are in parentheses. ${ }^{* * *} p<0.01, * * p<0.05, * p<0.1$. "e.c." denotes the error-correction term. 
Table B.1.2.2 - Equilibrium exchange rate model estimations (CFA)

\begin{tabular}{|c|c|c|c|c|c|c|c|c|}
\hline \multirow{3}{*}{$\begin{array}{l}\begin{array}{c}\text { Weighting } \\
\text { system }\end{array} \\
\text { Model }\end{array}$} & \multicolumn{5}{|c|}{ Fixed } & \multirow{2}{*}{\multicolumn{3}{|c|}{$\begin{array}{c}\text { Time-varying weights } \\
\text { (5-year averages) }\end{array}$}} \\
\hline & \multicolumn{2}{|c|}{$(1973-2016)$} & \multicolumn{3}{|c|}{$(2008-2012)$} & & & \\
\hline & (1) & (2) (3) & (1) & $(2)$ & (3) & (1) & $(2)$ & (3) \\
\hline \multicolumn{9}{|c|}{ Long-run dynamics } \\
\hline$B S$ & $\begin{array}{l}0.176^{* * *} \\
(0.0662)\end{array}$ & $\begin{array}{l}0.0726^{* *} \\
(0.0370)\end{array}$ & $\begin{array}{l}0.180 * * * \\
(0.0594)\end{array}$ & $\begin{array}{l}0.161^{* * *} \\
(0.0562)\end{array}$ & $\begin{array}{l}0.156^{* * *} \\
(0.0465)\end{array}$ & $\begin{array}{l}0.175^{* *} \\
(0.0823)\end{array}$ & $\begin{array}{l}-2.103^{*} \\
(1.095)\end{array}$ & $\begin{array}{c}0.0616 \\
(0.0408)\end{array}$ \\
\hline$N F A$ & & $\begin{array}{l}0.136 * * * \\
(0.0365)\end{array}$ & & $\begin{array}{l}0.192 * * * \\
(0.0705)\end{array}$ & $\begin{array}{c}0.168 * * * \\
(0.0588)\end{array}$ & & $\begin{array}{l}-0.282 \\
(0.380)\end{array}$ & $\begin{array}{l}0.191 * * * \\
(0.0398)\end{array}$ \\
\hline TOT & & $\begin{array}{l}-0.0135 \\
(0.0462)\end{array}$ & & & $\begin{array}{c}0.109^{*} \\
(0.0595)\end{array}$ & & & $\begin{array}{c}-0.0897^{*} \\
(0.0506)\end{array}$ \\
\hline \multicolumn{9}{|c|}{ Short-run dynamics } \\
\hline e.c. & $\begin{array}{c}-0.173 * * * \\
(0.0282)\end{array}$ & $\begin{array}{c}-0.251^{* * *} \\
(0.0394)\end{array}$ & $\begin{array}{c}-0.189 * * * \\
(0.0269)\end{array}$ & $\begin{array}{c}-0.185^{* * *} * \\
(0.0258)\end{array}$ & $\begin{array}{c}-0.221 * * * \\
(0.0395)\end{array}$ & $\begin{array}{c}-0.174 * * * \\
(0.0264)\end{array}$ & $\begin{array}{l}-0.0138 \\
(0.0136)\end{array}$ & $\begin{array}{c}-0.242 * * * \\
(0.0372)\end{array}$ \\
\hline$D . B S$ & $\begin{array}{c}-0.436^{*} \\
(0.249)\end{array}$ & $\begin{array}{l}-0.494 \\
(0.313)\end{array}$ & $\begin{array}{c}-0.297 * * * \\
(0.0969)\end{array}$ & $\begin{array}{c}-0.321 * * * \\
(0.0974)\end{array}$ & $\begin{array}{c}-0.360 * * \\
(0.149)\end{array}$ & $\begin{array}{l}-0.149 * \\
(0.0847)\end{array}$ & $\begin{array}{l}-0.0928 \\
(0.0714)\end{array}$ & $\begin{array}{l}-0.179 \\
(0.164)\end{array}$ \\
\hline D.NFA & & $\begin{array}{l}0.202^{* *} \\
(0.0958)\end{array}$ & & $\begin{array}{l}0.203 * * * \\
(0.0625)\end{array}$ & $\begin{array}{l}0.189 * * \\
(0.0804)\end{array}$ & & $\begin{array}{l}0.223 * * * \\
(0.0549)\end{array}$ & $\begin{array}{l}0.135^{* *} \\
(0.0613)\end{array}$ \\
\hline D.TOT & & $\begin{array}{l}-0.0274 \\
(0.107)\end{array}$ & & & $\begin{array}{c}-0.0481 \\
(0.0758)\end{array}$ & & & $\begin{array}{r}-0.0768 \\
(0.189)\end{array}$ \\
\hline Constant & $\begin{array}{c}0.848^{* * *} \\
(0.140)\end{array}$ & $\begin{array}{c}1.227^{* * *} \\
(0.195)\end{array}$ & $\begin{array}{c}0.923 * * * \\
(0.133)\end{array}$ & $\begin{array}{c}0.922 * * * \\
(0.130)\end{array}$ & $\begin{array}{c}0.995 * * * \\
(0.178)\end{array}$ & $\begin{array}{c}0.852 * * * \\
(0.131)\end{array}$ & $\begin{array}{l}-0.0185^{* *} \\
(0.00873)\end{array}$ & $\begin{array}{c}1.269 * * * \\
(0.199)\end{array}$ \\
\hline
\end{tabular}

Note: Standard errors are in parentheses. ${ }^{* * *} \mathrm{p}<0.01, * * \mathrm{p}<0.05, * \mathrm{p}<0.1$. "e.c." denotes the error-correction term. 
Table B.1.2.3 - Equilibrium exchange rate model estimations (CMA)

\begin{tabular}{|c|c|c|c|c|c|c|c|c|c|}
\hline \multirow{3}{*}{$\begin{array}{l}\begin{array}{c}\text { Weighting } \\
\text { system }\end{array} \\
\text { Model }\end{array}$} & \multicolumn{6}{|c|}{ Fixed } & \multirow{2}{*}{\multicolumn{3}{|c|}{$\begin{array}{c}\text { Time-varying weights } \\
\text { (5-year averages) }\end{array}$}} \\
\hline & \multicolumn{3}{|c|}{$(1973-2016)$} & \multicolumn{3}{|c|}{$(2008-2012)$} & & & \\
\hline & (1) & $(2)$ & (3) & (1) & (2) & (3) & (1) & (2) & (3) \\
\hline \multicolumn{10}{|c|}{ Long-run dynamics } \\
\hline$B S$ & $\begin{array}{l}-1.807^{*} \\
(0.946)\end{array}$ & $\begin{array}{c}0.667 * * * \\
(0.157)\end{array}$ & $\begin{array}{c}0.796 * * * \\
(0.196)\end{array}$ & $\begin{array}{c}-1.551^{* *} \\
(0.748)\end{array}$ & $\begin{array}{c}1.585^{* * *} \\
(0.352)\end{array}$ & $\begin{array}{l}-0.613 \\
(0.458)\end{array}$ & $\begin{array}{c}-1.312^{* *} \\
(0.540)\end{array}$ & $\begin{array}{l}-0.184 \\
(0.211)\end{array}$ & $\begin{array}{l}-0.160 \\
(0.274)\end{array}$ \\
\hline$N F A$ & & $\begin{array}{c}0.172 * * * \\
(0.0666)\end{array}$ & $\begin{array}{l}0.228 * * \\
(0.0910)\end{array}$ & & $\begin{array}{c}0.253^{* * *} * \\
(0.0781)\end{array}$ & $\begin{array}{c}0.104 \\
(0.0783)\end{array}$ & & $\begin{array}{c}0.106 \\
(0.0738)\end{array}$ & $\begin{array}{c}0.184 * * \\
(0.0723)\end{array}$ \\
\hline TOT & & & $\begin{array}{c}0.129 \\
(0.556)\end{array}$ & & & $\begin{array}{c}0.708 * * * \\
(0.270)\end{array}$ & & & $\begin{array}{c}0.544^{*} \\
(0.326)\end{array}$ \\
\hline \multicolumn{10}{|c|}{ Short-run dynamics } \\
\hline e.c. & $\begin{array}{l}-0.0432 \\
(0.0309)\end{array}$ & $\begin{array}{l}-0.242^{*} \\
(0.130)\end{array}$ & $\begin{array}{l}-0.276^{*} \\
(0.151)\end{array}$ & $\begin{array}{l}-0.0507 \\
(0.0335)\end{array}$ & $\begin{array}{l}-0.214 \\
(0.132)\end{array}$ & $\begin{array}{l}-0.251^{*} \\
(0.151)\end{array}$ & $\begin{array}{l}-0.0641^{*} \\
(0.0378)\end{array}$ & $\begin{array}{l}-0.218^{*} \\
(0.124)\end{array}$ & $\begin{array}{l}-0.267^{*} \\
(0.152)\end{array}$ \\
\hline$D . B S$ & $\begin{array}{l}0.198 * * \\
(0.0874)\end{array}$ & $\begin{array}{r}-0.0964 \\
(0.198)\end{array}$ & $\begin{array}{r}-0.0933 \\
(0.153)\end{array}$ & $\begin{array}{c}0.249 * \\
(0.133)\end{array}$ & $\begin{array}{c}-0.176 \\
(0.201)\end{array}$ & $\begin{array}{c}0.271 \\
(0.254)\end{array}$ & $\begin{array}{c}0.219 * * \\
(0.101)\end{array}$ & $\begin{array}{c}0.213 \\
(0.159)\end{array}$ & $\begin{array}{c}0.223^{* *} \\
(0.111)\end{array}$ \\
\hline$D . N F A$ & & $\begin{array}{c}0.114^{*} \\
(0.0591)\end{array}$ & $\begin{array}{c}0.0594 \\
(0.0859)\end{array}$ & & $\begin{array}{c}0.0527 \\
(0.0697)\end{array}$ & $\begin{array}{c}0.108 \\
(0.0659)\end{array}$ & & $\begin{array}{l}0.167^{* *} \\
(0.0658)\end{array}$ & $\begin{array}{c}0.133^{*} \\
(0.0781)\end{array}$ \\
\hline D.TOT & & & $\begin{array}{l}-0.317 \\
(0.347)\end{array}$ & & & $\begin{array}{c}0.0411 \\
(0.223)\end{array}$ & & & $\begin{array}{c}-0.512 \\
(0.500)\end{array}$ \\
\hline Constant & $\begin{array}{c}0.0709 \\
(0.0795)\end{array}$ & $\begin{array}{l}1.318^{*} \\
(0.768)\end{array}$ & $\begin{array}{l}1.393^{*} \\
(0.837)\end{array}$ & $\begin{array}{c}0.124 \\
(0.101)\end{array}$ & $\begin{array}{c}1.372 \\
(0.989)\end{array}$ & $\begin{array}{c}0.126 \\
(0.103)\end{array}$ & $\begin{array}{c}0.165 \\
(0.107)\end{array}$ & $\begin{array}{l}0.936^{*} \\
(0.544)\end{array}$ & $\begin{array}{l}0.496^{*} \\
(0.293)\end{array}$ \\
\hline
\end{tabular}


Table B.1.2.4 - Equilibrium exchange rate model estimations (ECMU)

\begin{tabular}{|c|c|c|c|c|c|c|c|c|c|}
\hline \multirow{3}{*}{$\begin{array}{c}\begin{array}{c}\text { Weighting } \\
\text { system }\end{array} \\
\text { Model }\end{array}$} & \multicolumn{6}{|c|}{ Fixed } & \multirow{2}{*}{\multicolumn{3}{|c|}{$\begin{array}{c}\text { Time-varying weights } \\
\text { (5-year averages) }\end{array}$}} \\
\hline & \multicolumn{3}{|c|}{$(1973-2016)$} & \multicolumn{3}{|c|}{$(2008-2012)$} & & & \\
\hline & (1) & $(2)$ & (3) & (1) & (2) & (3) & (1) & $(2)$ & (3) \\
\hline \multicolumn{10}{|c|}{ Long-run dynamics } \\
\hline$B S$ & $\begin{array}{c}0.0305 \\
(0.0602)\end{array}$ & $\begin{array}{l}0.00392 \\
(0.0789)\end{array}$ & $\begin{array}{c}0.251 \\
(0.165)\end{array}$ & & $\begin{array}{l}-0.108 \\
(0.150)\end{array}$ & & & $\begin{array}{l}-0.00312 \\
(0.0947)\end{array}$ & $\begin{array}{l}-0.819 \\
(1.362)\end{array}$ \\
\hline$N F A$ & & $\begin{array}{l}0.228 * * * \\
(0.0327)\end{array}$ & $\begin{array}{c}0.0886 * * * \\
(0.0263)\end{array}$ & & $\begin{array}{l}0.423 * * * \\
(0.0934)\end{array}$ & & & $\begin{array}{l}0.191^{* * *} * \\
(0.0324)\end{array}$ & $\begin{array}{l}-0.778 \\
(1.421)\end{array}$ \\
\hline TOT & & & $\begin{array}{c}0.0684 \\
(0.143)\end{array}$ & & & & & & $\begin{array}{c}6.354 \\
(9.566)\end{array}$ \\
\hline \multicolumn{10}{|c|}{ Short-run dynamics } \\
\hline e.c. & $\begin{array}{c}-0.160 * * * \\
(0.0576)\end{array}$ & $\begin{array}{c}-0.0990^{*} \\
(0.0533)\end{array}$ & $\begin{array}{c}-0.165^{* * *} \\
(0.0320)\end{array}$ & & $\begin{array}{c}-0.0575^{*} \\
(0.0320)\end{array}$ & & & $\begin{array}{c}-0.101^{* *} \\
(0.0484)\end{array}$ & $\begin{array}{l}0.00455 \\
(0.0103)\end{array}$ \\
\hline$D . B S$ & $\begin{array}{c}-0.0503 * * * \\
(0.0164)\end{array}$ & $\begin{array}{c}-0.0468 * * * \\
(0.0146)\end{array}$ & $\begin{array}{c}-0.0421 * * * \\
(0.0118)\end{array}$ & & $\begin{array}{c}-0.0565 * * * \\
(0.0191)\end{array}$ & & & $\begin{array}{c}-0.0235 * * * \\
(0.00790)\end{array}$ & $\begin{array}{l}-0.0154^{*} \\
(0.00822)\end{array}$ \\
\hline D.NFA & & $\begin{array}{c}-0.0349 * * \\
(0.0165)\end{array}$ & $\begin{array}{c}-0.0386^{*} \\
(0.0204)\end{array}$ & & $\begin{array}{l}-0.0199 \\
(0.0121)\end{array}$ & & & $\begin{array}{l}-0.0314^{*} \\
(0.0189)\end{array}$ & $\begin{array}{l}-0.0362 \\
(0.0365)\end{array}$ \\
\hline D.TOT & & & $\begin{array}{l}0.000961 \\
(0.0588)\end{array}$ & & & & & & $\begin{array}{c}0.0379 \\
(0.0684)\end{array}$ \\
\hline Constant & $\begin{array}{c}0.744 * * * \\
(0.265)\end{array}$ & $\begin{array}{l}0.487^{*} \\
(0.262)\end{array}$ & $\begin{array}{c}0.769 * * * \\
(0.152)\end{array}$ & & $\begin{array}{l}0.287^{*} \\
(0.158)\end{array}$ & & & $\begin{array}{l}0.490 * * \\
(0.235)\end{array}$ & $\begin{array}{c}0.116 \\
(0.273)\end{array}$ \\
\hline
\end{tabular}

Note: Standard errors are in parentheses. ${ }^{* * *} \mathrm{p}<0.01,{ }^{* *} \mathrm{p}<0.05,{ }^{*} \mathrm{p}<0.1$. "e.c." denotes the error-correction term. 
Table B.1.2.5 - Equilibrium exchange rate model estimations (EMU)

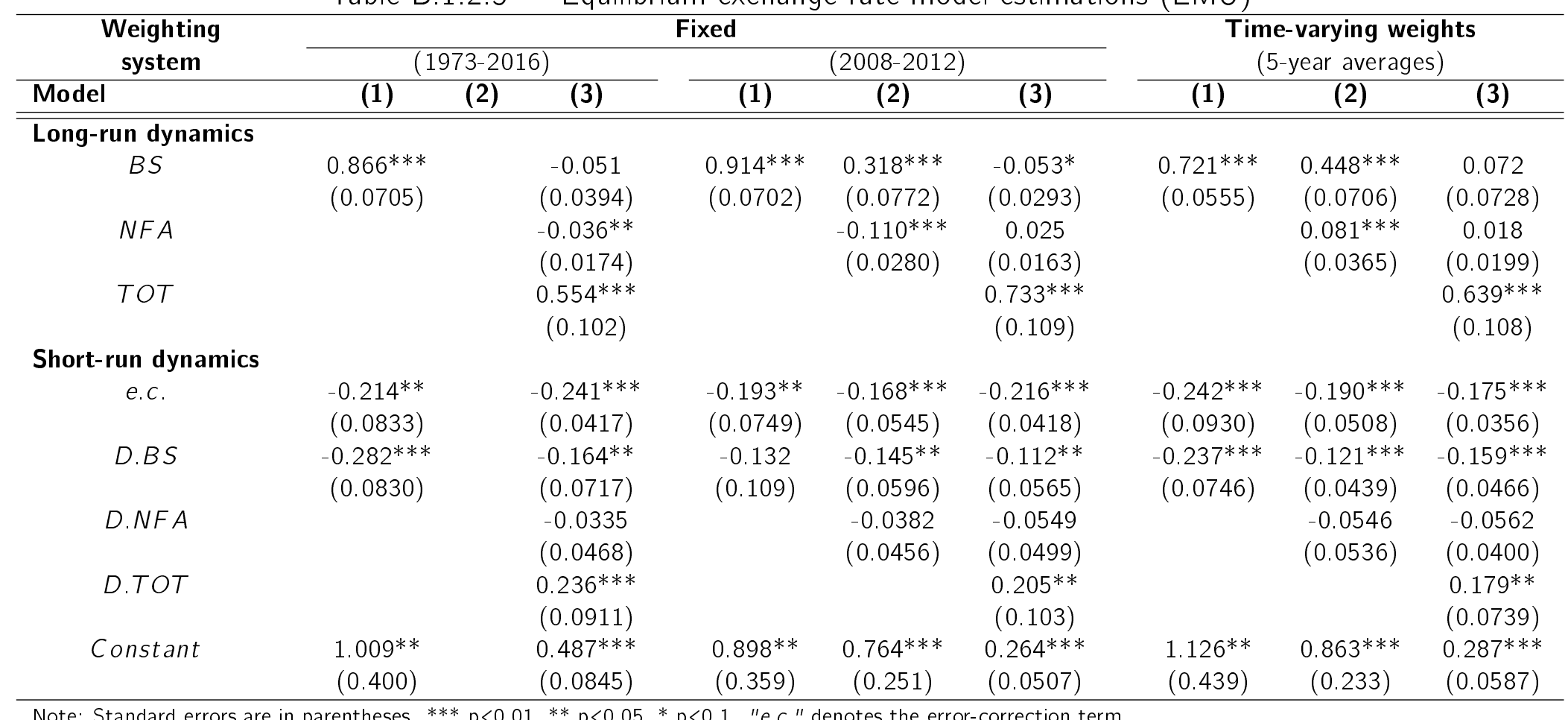


Table B.1.2.6 - Equilibrium exchange rate model estimations (WAEMU)

\begin{tabular}{|c|c|c|c|c|c|c|c|c|c|}
\hline \multirow{3}{*}{$\begin{array}{c}\begin{array}{c}\text { Weighting } \\
\text { system }\end{array} \\
\text { Model }\end{array}$} & \multicolumn{6}{|c|}{ Fixed } & \multirow{2}{*}{\multicolumn{3}{|c|}{$\begin{array}{l}\text { Time-varying weights } \\
\text { (5-year averages) }\end{array}$}} \\
\hline & \multicolumn{3}{|c|}{$(1973-2016)$} & \multicolumn{3}{|c|}{$(2008-2012)$} & & & \\
\hline & (1) & $(2)$ & (3) & (1) & $(2)$ & (3) & (1) & $(2)$ & (3) \\
\hline \multicolumn{10}{|c|}{ Long-run dynamics } \\
\hline$B S$ & $\begin{array}{l}-0.0212 \\
(0.0841)\end{array}$ & $\begin{array}{c}-5.084^{* * *} \\
(1.028)\end{array}$ & $\begin{array}{l}0.0146 \\
(0.171)\end{array}$ & $\begin{array}{l}0.187^{* *} \\
(0.0780)\end{array}$ & $\begin{array}{l}0.194 * * * \\
(0.0724)\end{array}$ & $\begin{array}{c}0.146 \\
(0.0952)\end{array}$ & $\begin{array}{c}0.0420 \\
(0.0957)\end{array}$ & $\begin{array}{l}-2.913 \\
(1.884)\end{array}$ & $\begin{array}{c}-0.357^{* *} \\
(0.174)\end{array}$ \\
\hline$N F A$ & & $\begin{array}{c}-2.278^{* * *} \\
(0.725)\end{array}$ & $\begin{array}{c}0.119 \\
(0.0994)\end{array}$ & & $\begin{array}{l}0.202^{* *} \\
(0.0957)\end{array}$ & $\begin{array}{l}0.220 * * \\
(0.102)\end{array}$ & & $\begin{array}{l}-1.314 \\
(1.230)\end{array}$ & $\begin{array}{c}0.0104 \\
(0.0468)\end{array}$ \\
\hline TOT & & & $\begin{array}{l}0.376^{* *} \\
(0.185)\end{array}$ & & & $\begin{array}{c}0.263^{* *} \\
(0.120)\end{array}$ & & & $\begin{array}{c}0.564^{* * * *} \\
(0.164)\end{array}$ \\
\hline \multicolumn{10}{|c|}{ Short-run dynamics } \\
\hline e.c. & $\begin{array}{c}-0.197 * * * \\
(0.0384)\end{array}$ & $\begin{array}{l}-0.0377 \\
(0.0403)\end{array}$ & $\begin{array}{c}-0.188 * * * \\
(0.0438)\end{array}$ & $\begin{array}{c}-0.202 * * * \\
(0.0345)\end{array}$ & $\begin{array}{c}-0.192^{* * *} \\
(0.0352)\end{array}$ & $\begin{array}{c}-0.230 * * * \\
(0.0476)\end{array}$ & $\begin{array}{c}-0.204^{* * *} \\
(0.0425)\end{array}$ & $\begin{array}{l}-0.0161 \\
(0.0197)\end{array}$ & $\begin{array}{r}-0.184 * * * \\
(0.0468)\end{array}$ \\
\hline$D . B S$ & $\begin{array}{l}-0.610 \\
(0.429)\end{array}$ & $\begin{array}{c}-0.497^{*} \\
(0.282)\end{array}$ & $\begin{array}{l}-0.743 \\
(0.529)\end{array}$ & $\begin{array}{c}-0.347^{* *} \\
(0.146)\end{array}$ & $\begin{array}{c}-0.356^{* *} \\
(0.143)\end{array}$ & $\begin{array}{c}-0.401^{* *} \\
(0.204)\end{array}$ & $\begin{array}{l}-0.189 \\
(0.144)\end{array}$ & $\begin{array}{l}-0.125 \\
(0.116)\end{array}$ & $\begin{array}{c}-0.238 \\
(0.283)\end{array}$ \\
\hline D.NFA & & $\begin{array}{c}0.370 * * * \\
(0.109)\end{array}$ & $\begin{array}{c}0.365 * * * \\
(0.141)\end{array}$ & & $\begin{array}{l}0.286 * * * \\
(0.0936)\end{array}$ & $\begin{array}{c}0.311^{* * *} \\
(0.116)\end{array}$ & & $\begin{array}{l}0.309 * * * \\
(0.0846)\end{array}$ & $\begin{array}{l}0.275^{* * * *} \\
(0.0758)\end{array}$ \\
\hline D.TOT & & & $\begin{array}{l}-0.131 \\
(0.167)\end{array}$ & & & $\begin{array}{l}-0.117 \\
(0.110)\end{array}$ & & & $\begin{array}{l}-0.280 \\
(0.327)\end{array}$ \\
\hline Constant & $\begin{array}{c}0.884^{* * *} \\
(0.177)\end{array}$ & $\begin{array}{l}-0.258 \\
(0.273)\end{array}$ & $\begin{array}{c}0.558 * * * \\
(0.130)\end{array}$ & $\begin{array}{c}0.991^{* * *} \\
(0.175)\end{array}$ & $\begin{array}{c}0.968 * * * \\
(0.183)\end{array}$ & $\begin{array}{c}0.878 * * * \\
(0.185)\end{array}$ & $\begin{array}{c}0.937^{* * * *} \\
(0.202)\end{array}$ & $\begin{array}{l}-0.0410 \\
(0.0406)\end{array}$ & $\begin{array}{l}0.245 * * * \\
(0.0716)\end{array}$ \\
\hline
\end{tabular}

Note: Standard errors are in parentheses. ${ }^{* * *} \mathrm{p}<0.01,{ }^{*} \mathrm{p}<0.05, * \mathrm{p}<0.1$. "e.c. " denotes the error-correction term. 
B.1.3. Geographical regions

Table B.1.3.1 - Equilibrium exchange rate model estimations (Africa)

\begin{tabular}{|c|c|c|c|c|c|c|c|c|c|}
\hline \multirow{3}{*}{$\begin{array}{cc}\begin{array}{c}\text { Weighting } \\
\text { system }\end{array} \\
\text { Model } \\
\end{array}$} & \multicolumn{6}{|c|}{ Fixed } & \multirow{2}{*}{\multicolumn{3}{|c|}{$\begin{array}{c}\text { Time-varying weights } \\
\text { (5-year averages) }\end{array}$}} \\
\hline & \multicolumn{3}{|c|}{$(1973-2016)$} & \multicolumn{3}{|c|}{$(2008-2012)$} & & & \\
\hline & (1) & $(2)$ & (3) & (1) & $(2)$ & (3) & (1) & $(2)$ & (3) \\
\hline \multicolumn{10}{|c|}{ Long-run dynamics } \\
\hline$B S$ & $\begin{array}{c}0.0273 \\
(0.0430)\end{array}$ & $\begin{array}{l}0.271^{* * *} \\
(0.0443)\end{array}$ & $\begin{array}{l}0.187 * * * \\
(0.0349)\end{array}$ & $\begin{array}{c}-0.288 * * * \\
(0.0557)\end{array}$ & $\begin{array}{l}0.197^{* * *} \\
(0.0387)\end{array}$ & $\begin{array}{c}0.0791 * * * \\
(0.0260)\end{array}$ & $\begin{array}{r}-0.00428 \\
(0.0368)\end{array}$ & $\begin{array}{l}0.134 * * * \\
(0.0318)\end{array}$ & $\begin{array}{l}0.148 * * * \\
(0.0365)\end{array}$ \\
\hline$N F A$ & & $\begin{array}{l}0.194 * * * \\
(0.0271)\end{array}$ & $\begin{array}{l}0.147^{* * *} \\
(0.0210)\end{array}$ & & $\begin{array}{l}0.169 * * * \\
(0.0256)\end{array}$ & $\begin{array}{c}0.128 * * * \\
(0.0176)\end{array}$ & & $\begin{array}{l}0.228 * * * \\
(0.0319)\end{array}$ & $\begin{array}{c}0.145^{* * *} \\
(0.0226)\end{array}$ \\
\hline TOT & & & $\begin{array}{c}0.0408 \\
(0.0449)\end{array}$ & & & $\begin{array}{r}-0.00741 \\
(0.0399)\end{array}$ & & & $\begin{array}{l}-0.0753 \\
(0.0463)\end{array}$ \\
\hline \multicolumn{10}{|c|}{ Short-run dynamics } \\
\hline e.c. & $\begin{array}{c}-0.152 * * * \\
(0.0257)\end{array}$ & $\begin{array}{c}-0.154 * * * \\
(0.0246)\end{array}$ & $\begin{array}{c}-0.191 * * * \\
(0.0248)\end{array}$ & $\begin{array}{c}-0.190 * * * \\
(0.0458)\end{array}$ & $\begin{array}{c}-0.172 * * * \\
(0.0262)\end{array}$ & $\begin{array}{c}-0.216 * * * \\
(0.0299)\end{array}$ & $\begin{array}{c}-0.148 * * * \\
(0.0263)\end{array}$ & $\begin{array}{c}-0.142 * * * \\
(0.0253)\end{array}$ & $\begin{array}{c}-0.179 * * * \\
(0.0247)\end{array}$ \\
\hline$D . B S$ & $\begin{array}{c}0.173 \\
(0.324)\end{array}$ & $\begin{array}{c}0.0945 \\
(0.364)\end{array}$ & $\begin{array}{c}0.0363 \\
(0.327)\end{array}$ & $\begin{array}{c}-0.211^{*} \\
(0.120)\end{array}$ & $\begin{array}{c}0.108 \\
(0.333)\end{array}$ & $\begin{array}{c}0.121 \\
(0.290)\end{array}$ & $\begin{array}{c}0.275 \\
(0.284)\end{array}$ & $\begin{array}{c}0.253 \\
(0.351)\end{array}$ & $\begin{array}{c}0.208 \\
(0.323)\end{array}$ \\
\hline D.NFA & & $\begin{array}{c}0.132 * * * \\
(0.0358)\end{array}$ & $\begin{array}{c}0.125^{* * *} \\
(0.0400)\end{array}$ & & $\begin{array}{c}0.122 * * * \\
(0.0350)\end{array}$ & $\begin{array}{c}0.113^{* * *} \\
(0.0375)\end{array}$ & & $\begin{array}{c}0.138 * * * \\
(0.0440)\end{array}$ & $\begin{array}{l}0.132 * * \\
(0.0519)\end{array}$ \\
\hline D.TOT & & & $\begin{array}{c}0.293 \\
(0.374)\end{array}$ & & & $\begin{array}{c}0.351 \\
(0.390)\end{array}$ & & & $\begin{array}{c}0.519 \\
(0.632)\end{array}$ \\
\hline Constant & $\begin{array}{c}0.756^{* * *} \\
(0.125)\end{array}$ & $\begin{array}{c}0.869 * * * \\
(0.141)\end{array}$ & $\begin{array}{c}0.957^{* * *} \\
(0.136)\end{array}$ & $\begin{array}{c}0.735^{* * *} \\
(0.150)\end{array}$ & $\begin{array}{c}0.939 * * * \\
(0.143)\end{array}$ & $\begin{array}{c}1.073 * * * \\
(0.156)\end{array}$ & $\begin{array}{c}0.739 * * * \\
(0.128)\end{array}$ & $\begin{array}{c}0.788^{* * *} \\
(0.140)\end{array}$ & $\begin{array}{c}0.992 * * * \\
(0.144)\end{array}$ \\
\hline
\end{tabular}

Note: Standard errors are in parentheses. ${ }^{* * *} \mathrm{p}<0.01,{ }^{* *} \mathrm{p}<0.05,{ }^{*} \mathrm{p}<0.1$. "e.c." denotes the error-correction term. 
Table B.1.3.2 - Equilibrium exchange rate model estimations (America)

\begin{tabular}{|c|c|c|c|c|c|c|c|c|c|}
\hline \multirow{2}{*}{$\begin{array}{l}\begin{array}{c}\text { Weighting } \\
\text { system }\end{array} \\
\text { Model }\end{array}$} & \multicolumn{3}{|c|}{$(1973-2016)$} & \multicolumn{3}{|c|}{$(2008-2012)$} & \multicolumn{3}{|c|}{$\begin{array}{l}\text { Time-varying weights } \\
\text { (5-year averages) }\end{array}$} \\
\hline & (1) & $(2)$ & (3) & (1) & $(2)$ & (3) & (1) & $(2)$ & (3) \\
\hline \multicolumn{10}{|c|}{ Long-run dynamics } \\
\hline$B S$ & $\begin{array}{r}-0.00914 \\
(0.0265)\end{array}$ & $\begin{array}{l}0.00558 \\
(0.0646)\end{array}$ & $\begin{array}{l}0.355 * * * \\
(0.0477)\end{array}$ & $\begin{array}{c}0.0184 \\
(0.0284)\end{array}$ & & $\begin{array}{l}0.329 * * * \\
(0.0337)\end{array}$ & $\begin{array}{l}-0.0254 \\
(0.0277)\end{array}$ & $\begin{array}{l}-0.0535 \\
(0.0678)\end{array}$ & $\begin{array}{c}0.325^{* * *} \\
(0.115)\end{array}$ \\
\hline$N F A$ & & $\begin{array}{c}0.235^{* * *} \\
(0.0284)\end{array}$ & $\begin{array}{c}-0.397 * * * \\
(0.0367)\end{array}$ & & & $\begin{array}{c}-0.357^{* * *} \\
(0.0275)\end{array}$ & & $\begin{array}{c}0.224 * * * \\
(0.0293)\end{array}$ & $\begin{array}{c}1.396 * * * \\
(0.184)\end{array}$ \\
\hline TOT & & & $\begin{array}{c}0.111^{*} \\
(0.0569)\end{array}$ & & & $\begin{array}{l}-0.0116 \\
(0.0429)\end{array}$ & & & $\begin{array}{l}0.196^{*} \\
(0.109)\end{array}$ \\
\hline \multicolumn{10}{|c|}{ Short-run dynamics } \\
\hline e.c. & $\begin{array}{c}-0.131^{* * *} \\
(0.0260)\end{array}$ & $\begin{array}{c}-0.0909 * * * \\
(0.0245)\end{array}$ & $\begin{array}{c}-0.0811^{* *} \\
(0.0318)\end{array}$ & $\begin{array}{c}-0.133^{* * *} \\
(0.0264)\end{array}$ & & $\begin{array}{c}-0.0837^{* *} \\
(0.0352)\end{array}$ & $\begin{array}{c}-0.129 * * * \\
(0.0253)\end{array}$ & $\begin{array}{c}-0.0906 * * * \\
(0.0235)\end{array}$ & $\begin{array}{c}-0.0753^{* * *} * \\
(0.0185)\end{array}$ \\
\hline$D . B S$ & $\begin{array}{l}0.371^{* *} \\
(0.169)\end{array}$ & $\begin{array}{l}0.340 * * \\
(0.138)\end{array}$ & $\begin{array}{c}0.830 \\
(0.624)\end{array}$ & $\begin{array}{l}0.324 * * \\
(0.162)\end{array}$ & & $\begin{array}{c}0.795 \\
(0.601)\end{array}$ & $\begin{array}{l}0.342 * * \\
(0.157)\end{array}$ & $\begin{array}{l}0.321^{* *} \\
(0.131)\end{array}$ & $\begin{array}{c}0.487 \\
(0.347)\end{array}$ \\
\hline$D . N F A$ & & $\begin{array}{l}-0.0234 \\
(0.114)\end{array}$ & $\begin{array}{c}0.148 * * * \\
(0.0463)\end{array}$ & & & $\begin{array}{l}0.164 * * * \\
(0.0456)\end{array}$ & & $\begin{array}{l}-0.0310 \\
(0.114)\end{array}$ & $\begin{array}{c}0.0188 \\
(0.0507)\end{array}$ \\
\hline D.TOT & & & $\begin{array}{l}-0.00103 \\
(0.0629)\end{array}$ & & & $\begin{array}{l}-0.0227 \\
(0.0584)\end{array}$ & & & $\begin{array}{r}-0.00254 \\
(0.0612)\end{array}$ \\
\hline Constant & $\begin{array}{c}0.608 * * * \\
(0.115)\end{array}$ & $\begin{array}{c}0.444^{* * *} \\
(0.107)\end{array}$ & $\begin{array}{l}0.339 * * \\
(0.137)\end{array}$ & $\begin{array}{c}0.622^{* * *} \\
(0.117)\end{array}$ & & $\begin{array}{c}0.396 * * \\
(0.169)\end{array}$ & $\begin{array}{c}0.599 * * * \\
(0.112)\end{array}$ & $\begin{array}{c}0.435^{* * * *} \\
(0.101)\end{array}$ & $\begin{array}{c}0.328 * * * \\
(0.0799)\end{array}$ \\
\hline
\end{tabular}

Note: Standard errors are in parentheses. ${ }^{* * *} p<0.01,{ }^{* *} p<0.05, * p<0.1$. "e.c." denotes the error-correction term. 
Table B.1.3.3 - Equilibrium exchange rate model estimations (Asia)

\begin{tabular}{|c|c|c|c|c|c|c|c|c|c|}
\hline \multirow{3}{*}{$\begin{array}{c}\begin{array}{c}\text { Weighting } \\
\text { system }\end{array} \\
\text { Model } \\
\end{array}$} & \multicolumn{6}{|c|}{ Fixed } & \multirow{2}{*}{\multicolumn{3}{|c|}{$\begin{array}{c}\text { Time-varying weights } \\
\text { (5-year averages) }\end{array}$}} \\
\hline & \multicolumn{3}{|c|}{$(1973-2016)$} & \multicolumn{3}{|c|}{$(2008-2012)$} & & & \\
\hline & (1) & $(2)$ & (3) & (1) & $(2)$ & (3) & (1) & $(2)$ & (3) \\
\hline \multicolumn{10}{|c|}{ Long-run dynamics } \\
\hline$B S$ & $\begin{array}{l}0.375^{* * *} \\
(0.0349)\end{array}$ & $\begin{array}{l}0.602 * * * \\
(0.0474)\end{array}$ & $\begin{array}{l}0.0643 * \\
(0.0336)\end{array}$ & $\begin{array}{l}0.368 * * * \\
(0.0326)\end{array}$ & $\begin{array}{l}0.0255^{* * *} \\
(0.00847)\end{array}$ & $\begin{array}{l}-0.0471 \\
(0.0396)\end{array}$ & $\begin{array}{l}0.356 * * * \\
(0.0341)\end{array}$ & $\begin{array}{c}0.0647^{* * *} \\
(0.0134)\end{array}$ & $\begin{array}{l}-0.00773 \\
(0.0191)\end{array}$ \\
\hline$N F A$ & & $\begin{array}{l}0.312 * * * \\
(0.0396)\end{array}$ & $\begin{array}{l}0.0256 * * \\
(0.0113)\end{array}$ & & $\begin{array}{l}0.0623 * * * \\
(0.00938)\end{array}$ & $\begin{array}{l}0.0303 * * * \\
(0.00938)\end{array}$ & & $\begin{array}{l}0.0462 * * * \\
(0.00888)\end{array}$ & $\begin{array}{l}0.0469 * * * \\
(0.00646)\end{array}$ \\
\hline TOT & & & $\begin{array}{l}0.174 * * * \\
(0.0310)\end{array}$ & & & $\begin{array}{l}0.299 * * * \\
(0.0340)\end{array}$ & & & $\begin{array}{l}-0.00589 \\
(0.0175)\end{array}$ \\
\hline \multicolumn{10}{|c|}{ Short-run dynamics } \\
\hline e.c. & $\begin{array}{c}-0.210 * * * \\
(0.0386)\end{array}$ & $\begin{array}{c}-0.156 * * * \\
(0.0293)\end{array}$ & $\begin{array}{c}-0.240 * * * \\
(0.0449)\end{array}$ & $\begin{array}{c}-0.211^{* * *} \\
(0.0384)\end{array}$ & $\begin{array}{c}-0.238 * * * \\
(0.0441)\end{array}$ & $\begin{array}{c}-0.230 * * * \\
(0.0480)\end{array}$ & $\begin{array}{c}-0.217^{* * *} \\
(0.0401)\end{array}$ & $\begin{array}{c}-0.222 * * * \\
(0.0417)\end{array}$ & $\begin{array}{c}-0.243 * * * \\
(0.0491)\end{array}$ \\
\hline$D . B S$ & $\begin{array}{c}0.353 \\
(0.296)\end{array}$ & $\begin{array}{c}0.203 \\
(0.248)\end{array}$ & $\begin{array}{c}0.0123 \\
(0.0687)\end{array}$ & $\begin{array}{c}0.303 \\
(0.273)\end{array}$ & $\begin{array}{c}0.254 \\
(0.275)\end{array}$ & $\begin{array}{l}0.00896 \\
(0.0626)\end{array}$ & $\begin{array}{c}0.316 \\
(0.223)\end{array}$ & $\begin{array}{c}0.222 \\
(0.201)\end{array}$ & $\begin{array}{c}0.0604 \\
(0.0507)\end{array}$ \\
\hline$D . N F A$ & & $\begin{array}{c}-0.0424 \\
(0.129)\end{array}$ & $\begin{array}{c}0.0458 \\
(0.0488)\end{array}$ & & $\begin{array}{r}-0.0920 \\
(0.169)\end{array}$ & $\begin{array}{c}0.0448 \\
(0.0487)\end{array}$ & & $\begin{array}{r}-0.0428 \\
(0.120)\end{array}$ & $\begin{array}{c}0.0273 \\
(0.0486)\end{array}$ \\
\hline D.TOT & & & $\begin{array}{c}0.0284 \\
(0.0657)\end{array}$ & & & $\begin{array}{c}0.0506 \\
(0.0695)\end{array}$ & & & $\begin{array}{c}0.0756 \\
(0.0667)\end{array}$ \\
\hline Constant & $\begin{array}{c}1.039 * * * \\
(0.193)\end{array}$ & $\begin{array}{c}0.831 * * * \\
(0.158)\end{array}$ & $\begin{array}{c}0.920 * * * \\
(0.172)\end{array}$ & $\begin{array}{c}1.042 * * * \\
(0.193)\end{array}$ & $\begin{array}{c}1.087 * * * \\
(0.202)\end{array}$ & $\begin{array}{c}0.738 * * * \\
(0.152)\end{array}$ & $\begin{array}{c}1.072 * * * \\
(0.201)\end{array}$ & $\begin{array}{c}1.023 * * * \\
(0.193)\end{array}$ & $\begin{array}{c}1.117^{* * *} \\
(0.225)\end{array}$ \\
\hline
\end{tabular}

Note: Standard errors are in parentheses. ${ }^{* * *} \mathrm{p}<0.01,{ }^{* *} \mathrm{p}<0.05, * \mathrm{p}<0.1$. "e.c." denotes the error-correction term. 
Table B.1.3.4 - Equilibrium exchange rate model estimations (Europe)

\begin{tabular}{|c|c|c|c|c|c|c|c|c|c|}
\hline \multirow{3}{*}{$\begin{array}{c}\begin{array}{c}\text { Weighting } \\
\text { system }\end{array} \\
\text { Model }\end{array}$} & \multicolumn{6}{|c|}{ Fixed } & \multirow{2}{*}{\multicolumn{3}{|c|}{$\begin{array}{l}\text { Time-varying weights } \\
\text { (5-year averages) }\end{array}$}} \\
\hline & \multicolumn{3}{|c|}{$(1973-2016)$} & \multicolumn{3}{|c|}{$(2008-2012)$} & & & \\
\hline & (1) & (2) & (3) & (1) & (2) & (3) & (1) & (2) & (3) \\
\hline \multicolumn{10}{|c|}{ Long-run dynamics } \\
\hline$B S$ & $\begin{array}{l}0.431 * * * \\
(0.0458)\end{array}$ & $\begin{array}{l}0.482 * * * \\
(0.0637)\end{array}$ & $\begin{array}{l}0.000893 \\
(0.0323)\end{array}$ & $\begin{array}{l}0.382^{* * *} \\
(0.0480)\end{array}$ & $\begin{array}{l}0.542^{* * *} \\
(0.0621)\end{array}$ & $\begin{array}{l}-0.0430^{*} \\
(0.0235)\end{array}$ & $\begin{array}{l}0.526 * * * \\
(0.0402)\end{array}$ & $\begin{array}{l}0.327^{* * *} \\
(0.0494)\end{array}$ & $\begin{array}{l}0.0737^{* *} \\
(0.0345)\end{array}$ \\
\hline NFA & & $\begin{array}{c}-0.141^{* * *} \\
(0.0271)\end{array}$ & $\begin{array}{c}0.0142 \\
(0.00887)\end{array}$ & & $\begin{array}{c}-0.0644 * * * \\
(0.0138)\end{array}$ & $\begin{array}{c}-0.0622 * * * \\
(0.0174)\end{array}$ & & $\begin{array}{c}-0.0842^{* * *} \\
(0.0182)\end{array}$ & $\begin{array}{c}-0.0595^{* * *} \\
(0.0143)\end{array}$ \\
\hline TOT & & & $\begin{array}{c}0.787 * * * \\
(0.0729)\end{array}$ & & & $\begin{array}{c}0.776 * * * \\
(0.0749)\end{array}$ & & & $\begin{array}{l}1.122^{* * *} \\
(0.0909)\end{array}$ \\
\hline \multicolumn{10}{|c|}{ Short-run dynamics } \\
\hline e.c. & $\begin{array}{c}-0.293^{* * *} \\
(0.0536)\end{array}$ & $\begin{array}{c}-0.197^{* * *} \\
(0.0426)\end{array}$ & $\begin{array}{r}-0.0374 \\
(0.216)\end{array}$ & $\begin{array}{c}-0.273^{* * *} \\
(0.0505)\end{array}$ & $\begin{array}{c}-0.224 * * * \\
(0.0504)\end{array}$ & $\begin{array}{r}-0.0261 \\
(0.203)\end{array}$ & $\begin{array}{c}-0.305^{* * *} \\
(0.0584)\end{array}$ & $\begin{array}{c}-0.222^{* * *} \\
(0.0414)\end{array}$ & $\begin{array}{l}-0.136 \\
(0.0928)\end{array}$ \\
\hline$D . B S$ & $\begin{array}{l}0.0379 \\
(0.241)\end{array}$ & $\begin{array}{c}-0.147 \\
(0.0946)\end{array}$ & $\begin{array}{c}0.716 \\
(0.823)\end{array}$ & $\begin{array}{l}0.0598 \\
(0.210)\end{array}$ & $\begin{array}{c}-0.125 \\
(0.0956)\end{array}$ & $\begin{array}{c}0.770 \\
(0.831)\end{array}$ & $\begin{array}{c}0.126 \\
(0.272)\end{array}$ & $\begin{array}{l}0.0976 \\
(0.145)\end{array}$ & $\begin{array}{c}0.172 \\
(0.229)\end{array}$ \\
\hline D.NFA & & $\begin{array}{l}-0.0384 \\
(0.0397)\end{array}$ & $\begin{array}{l}-0.206 \\
(0.168)\end{array}$ & & $\begin{array}{l}-0.0375 \\
(0.0347)\end{array}$ & $\begin{array}{l}-0.213 \\
(0.174)\end{array}$ & & $\begin{array}{l}-0.0588 \\
(0.0415)\end{array}$ & $\begin{array}{l}-0.103 \\
(0.0681)\end{array}$ \\
\hline D.TOT & & & $\begin{array}{l}-1.133 \\
(1.279)\end{array}$ & & & $\begin{array}{l}-1.203 \\
(1.314)\end{array}$ & & & $\begin{array}{c}-0.672 \\
(0.655)\end{array}$ \\
\hline Constant & $\begin{array}{c}1.386 * * * \\
(0.258)\end{array}$ & $\begin{array}{c}0.918^{* * *} \\
(0.201)\end{array}$ & $\begin{array}{l}0.00216 \\
(0.252)\end{array}$ & $\begin{array}{c}1.282^{* * *} * \\
(0.240)\end{array}$ & $\begin{array}{c}1.057 * * * \\
(0.240)\end{array}$ & $\begin{array}{c}-0.00353 \\
(0.232)\end{array}$ & $\begin{array}{c}1.453 * * * \\
(0.282)\end{array}$ & $\begin{array}{c}1.022^{* * *} * \\
(0.193)\end{array}$ & $\begin{array}{c}-0.0984 * * * \\
(0.0345)\end{array}$ \\
\hline
\end{tabular}

Note: Standard errors are in parentheses. ${ }^{* * *} p<0.01,{ }^{* *} \mathrm{p}<0.05, * \mathrm{p}<0.1$. "e.c." denotes the error-correction term. 
Table B.1.3.5 - Equilibrium exchange rate model estimations (Oceania)

\begin{tabular}{|c|c|c|c|c|c|c|c|c|c|}
\hline \multirow{2}{*}{$\begin{array}{l}\text { Weighting } \\
\text { system } \\
\text { Model }\end{array}$} & \multicolumn{6}{|c|}{ Fixed } & \multicolumn{3}{|c|}{$\begin{array}{l}\text { Time-varying weights } \\
\text { (5-year averages) }\end{array}$} \\
\hline & (1) & $(2)$ & (3) & (1) & (2) & (3) & (1) & (2) & (3) \\
\hline \multicolumn{10}{|l|}{ Long-run dynamics } \\
\hline$B S$ & $\begin{array}{c}0.892^{* * *} \\
(0.109)\end{array}$ & $\begin{array}{l}0.919 * * * \\
(0.0907)\end{array}$ & $\begin{array}{c}0.520 * * * \\
(0.149)\end{array}$ & $\begin{array}{c}1.334 * * * \\
(0.223)\end{array}$ & $\begin{array}{c}-0.274 * * * \\
(0.0825)\end{array}$ & $\begin{array}{c}0.415^{* * *} \\
(0.133)\end{array}$ & $\begin{array}{l}0.509 * * * \\
(0.0578)\end{array}$ & $\begin{array}{l}0.521^{* * *} \\
(0.0514)\end{array}$ & $\begin{array}{l}0.387^{* *} \\
(0.163)\end{array}$ \\
\hline \multirow[t]{2}{*}{$N F A$} & & $-0.0979 * *$ & 0.0602 & & $-0.0740^{* * *}$ & -0.0644 & & $-0.114^{* * *}$ & 0.0574 \\
\hline & & $(0.0427)$ & $(0.0791)$ & & $(0.0125)$ & $(0.0795)$ & & $(0.0383)$ & $(0.0608)$ \\
\hline TOT & & & $\begin{array}{c}1.704 * * * \\
(0.204)\end{array}$ & & & $\begin{array}{c}1.765^{* * *} \\
(0.224)\end{array}$ & & & $\begin{array}{c}0.928^{* * *} \\
(0.131)\end{array}$ \\
\hline \multicolumn{10}{|l|}{ Short-run dynamics } \\
\hline e.c. & $\begin{array}{c}-0.117^{* *} \\
(0.0479)\end{array}$ & $\begin{array}{c}-0.138^{* * *} \\
(0.0491)\end{array}$ & $\begin{array}{l}-0.0653 \\
(0.0527)\end{array}$ & $\begin{array}{c}-0.0627^{*} \\
(0.0368)\end{array}$ & $\begin{array}{c}-0.240 * * * \\
(0.0811)\end{array}$ & $\begin{array}{l}-0.0733 \\
(0.0554)\end{array}$ & $\begin{array}{c}-0.172 * * * \\
(0.0463)\end{array}$ & $\begin{array}{c}-0.192 * * * \\
(0.0481)\end{array}$ & $\begin{array}{c}-0.141^{* *} \\
(0.0558)\end{array}$ \\
\hline$D . B S$ & $\begin{array}{l}-0.110 \\
(0.104)\end{array}$ & $\begin{array}{l}-0.163 \\
(0.105)\end{array}$ & $\begin{array}{r}-0.0972 \\
(0.192)\end{array}$ & $\begin{array}{r}-0.0963 \\
(0.101)\end{array}$ & $\begin{array}{c}-0.105 \\
(0.0976)\end{array}$ & $\begin{array}{c}-0.0622 \\
(0.226)\end{array}$ & $\begin{array}{l}-0.0275 \\
(0.0711)\end{array}$ & $\begin{array}{l}-0.0544 \\
(0.0758)\end{array}$ & $\begin{array}{l}-0.109 \\
(0.0672)\end{array}$ \\
\hline D.NFA & & $\begin{array}{c}0.102 \\
(0.114)\end{array}$ & $\begin{array}{c}0.0574 \\
(0.0768)\end{array}$ & & $\begin{array}{c}0.107 \\
(0.0975)\end{array}$ & $\begin{array}{c}0.0577 \\
(0.0710)\end{array}$ & & $\begin{array}{l}0.0861 \\
(0.106)\end{array}$ & $\begin{array}{c}0.0474 \\
(0.0834)\end{array}$ \\
\hline D.TOT & & & $\begin{array}{l}-0.0316 \\
(0.0928)\end{array}$ & & & $\begin{array}{l}-0.0643 \\
(0.0941)\end{array}$ & & & $\begin{array}{l}-0.0683 \\
(0.0962)\end{array}$ \\
\hline Constant & $\begin{array}{l}0.753^{* *} \\
(0.313)\end{array}$ & $\begin{array}{c}0.893 * * * \\
(0.317)\end{array}$ & $\begin{array}{l}-0.187 \\
(0.150)\end{array}$ & $\begin{array}{l}0.448^{*} \\
(0.267)\end{array}$ & $\begin{array}{c}0.984^{* * *} \\
(0.319)\end{array}$ & $\begin{array}{l}-0.246 \\
(0.186)\end{array}$ & $\begin{array}{c}0.914^{* * *} \\
(0.254)\end{array}$ & $\begin{array}{c}1.046^{* * *} \\
(0.266)\end{array}$ & $\begin{array}{l}0.130^{* *} \\
(0.0510)\end{array}$ \\
\hline
\end{tabular}




\section{B.1.4. Geographical sub-regions}

Table B.1.4.1 - Equilibrium exchange rate model estimations (Caribbean)

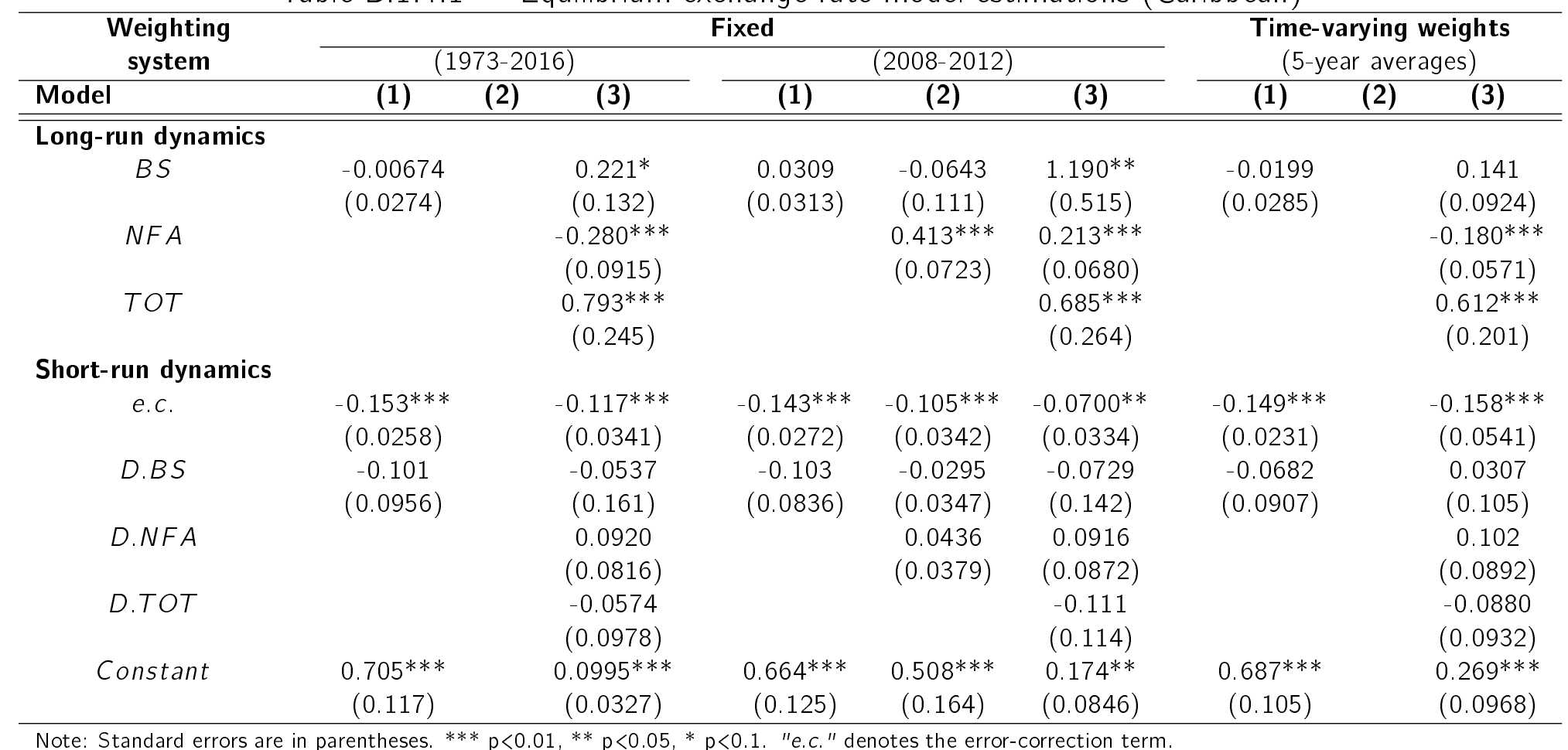


Table B.1.4.2 - Equilibrium exchange rate model estimations (central America)

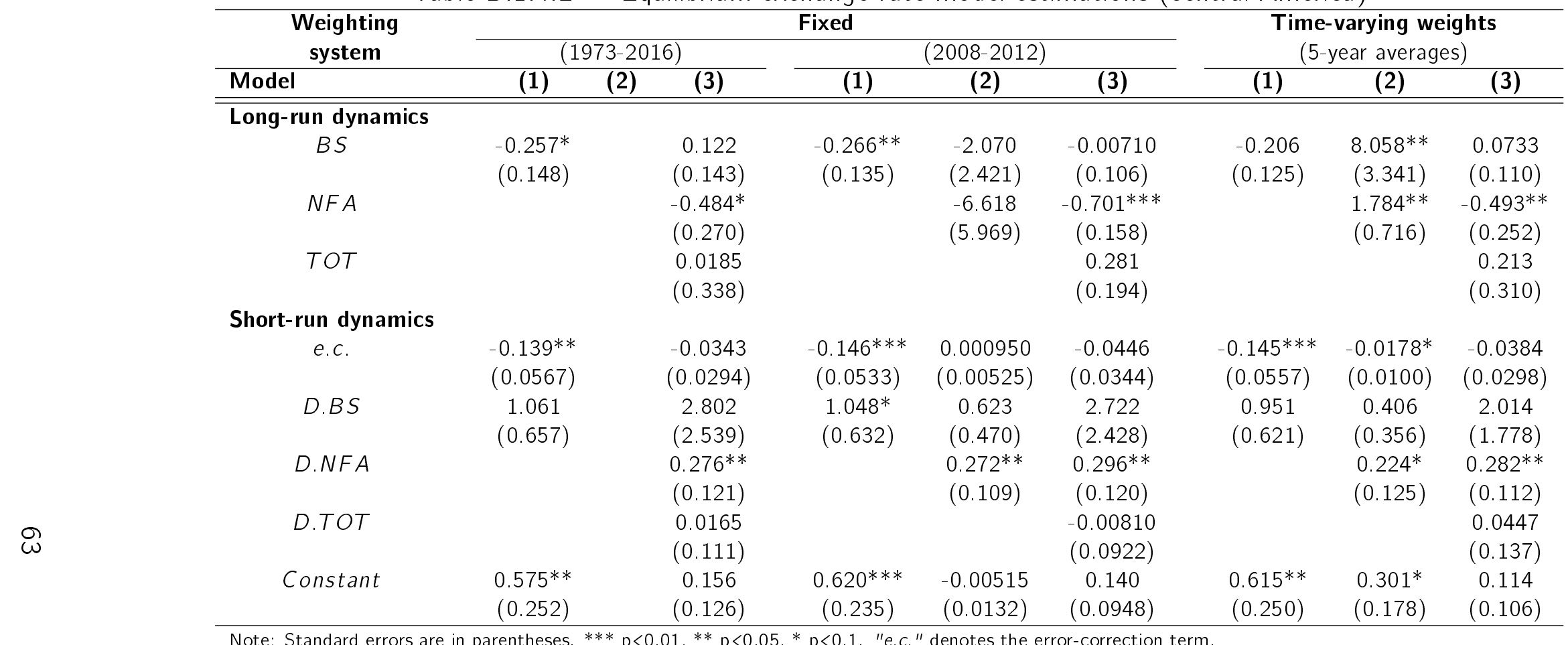


Table B.1.4.3 - Equilibrium exchange rate model estimations (central Asia)

\begin{tabular}{|c|c|c|c|c|c|c|c|c|c|}
\hline \multirow{2}{*}{$\begin{array}{l}\begin{array}{c}\text { Weighting } \\
\text { system }\end{array} \\
\text { Model }\end{array}$} & \multicolumn{6}{|c|}{ Fixed } & \multirow{2}{*}{\multicolumn{3}{|c|}{$\begin{array}{c}\text { Time-varying weights } \\
\text { (5-year averages) }\end{array}$}} \\
\hline & \multicolumn{2}{|c|}{$(1973-2016)$} & (3) & \multicolumn{3}{|c|}{$(2008-2012)$} & & & (3) \\
\hline \multicolumn{10}{|c|}{ Long-run dynamics } \\
\hline$B S$ & $\begin{array}{c}0.897^{* * *} \\
(0.289)\end{array}$ & $\begin{array}{l}-0.451 \\
(0.341)\end{array}$ & $\begin{array}{l}0.371^{* * *} \\
(0.0952)\end{array}$ & $\begin{array}{c}0.899 * * * \\
(0.176)\end{array}$ & $\begin{array}{c}0.466 \\
(0.296)\end{array}$ & $\begin{array}{c}0.143^{*} \\
(0.0784)\end{array}$ & $\begin{array}{c}0.754^{* * *} \\
(0.245)\end{array}$ & $\begin{array}{c}-0.697^{* *} \\
(0.352)\end{array}$ & $\begin{array}{l}-4.466 \\
(2.965)\end{array}$ \\
\hline$N F A$ & & $\begin{array}{c}-0.716 * * * \\
(0.165)\end{array}$ & $\begin{array}{l}0.201 * * * \\
(0.0499)\end{array}$ & & $\begin{array}{c}0.321 * * * \\
(0.116)\end{array}$ & $\begin{array}{c}-0.293 * * * \\
(0.0721)\end{array}$ & & $\begin{array}{c}-1.319 * * * \\
(0.351)\end{array}$ & $\begin{array}{l}3.880 \\
(4.826)\end{array}$ \\
\hline TOT & & & $\begin{array}{l}-0.0400 \\
(0.144)\end{array}$ & & & $\begin{array}{l}0.265^{* * *} \\
(0.0417)\end{array}$ & & & $\begin{array}{l}-1.272 \\
(1.475)\end{array}$ \\
\hline \multicolumn{10}{|c|}{ Short-run dynamics } \\
\hline e.c. & $\begin{array}{l}-0.421^{* * *} \\
(0.103)\end{array}$ & $\begin{array}{c}-0.418 * * * \\
(0.0725)\end{array}$ & $\begin{array}{c}-0.297 * * \\
(0.143)\end{array}$ & $\begin{array}{l}-0.452 * * * \\
(0.127)\end{array}$ & $\begin{array}{c}-0.357^{* *} \\
(0.167)\end{array}$ & $\begin{array}{l}-0.540 \\
(0.373)\end{array}$ & $\begin{array}{c}-0.417^{* * *} \\
(0.100)\end{array}$ & $\begin{array}{c}-0.299 * * \\
(0.150)\end{array}$ & $\begin{array}{c}0.0317 \\
(0.0442)\end{array}$ \\
\hline$D . B S$ & $\begin{array}{c}2.350 \\
(2.665)\end{array}$ & $\begin{array}{c}2.687 \\
(2.863)\end{array}$ & $\begin{array}{l}0.00622 \\
(0.214)\end{array}$ & $\begin{array}{c}2.209 \\
(2.455)\end{array}$ & $\begin{array}{c}2.837 \\
(3.114)\end{array}$ & $\begin{array}{r}-0.0608 \\
(0.183)\end{array}$ & $\begin{array}{c}1.751 \\
(1.997)\end{array}$ & $\begin{array}{c}2.249 \\
(2.293)\end{array}$ & $\begin{array}{l}0.0959 \\
(0.188)\end{array}$ \\
\hline$D . N F A$ & & $\begin{array}{l}-0.991 \\
(1.297)\end{array}$ & $\begin{array}{l}-0.122 \\
(0.162)\end{array}$ & & $\begin{array}{l}-2.065 \\
(1.904)\end{array}$ & $\begin{array}{c}0.0798 \\
(0.190)\end{array}$ & & $\begin{array}{l}-0.961 \\
(1.268)\end{array}$ & $\begin{array}{c}0.158 \\
(0.308)\end{array}$ \\
\hline D.TOT & & & $\begin{array}{c}-0.164 \\
(0.140)\end{array}$ & & & $\begin{array}{c}-0.249 * * \\
(0.124)\end{array}$ & & & $\begin{array}{l}-0.0937 \\
(0.0817)\end{array}$ \\
\hline Constant & $\begin{array}{c}2.310 * * * \\
(0.650)\end{array}$ & $\begin{array}{c}1.618^{* * *} \\
(0.377)\end{array}$ & $\begin{array}{c}1.607^{* *} \\
(0.796)\end{array}$ & $\begin{array}{c}2.557^{* * *} \\
(0.801)\end{array}$ & $\begin{array}{l}1.796 * * \\
(0.853)\end{array}$ & $\begin{array}{c}1.843 \\
(1.227)\end{array}$ & $\begin{array}{c}2.279 * * * \\
(0.627)\end{array}$ & $\begin{array}{c}1.152^{*} \\
(0.627)\end{array}$ & $\begin{array}{l}-0.297 \\
(0.360)\end{array}$ \\
\hline
\end{tabular}

Note: Standard errors are in parentheses. ${ }^{* * *} \mathrm{p}<0.01,{ }^{* *} \mathrm{p}<0.05,{ }^{*} \mathrm{p}<0.1$. "e.c." denotes the error-correction term. 
Table B.1.4.4 - Equilibrium exchange rate model estimations (eastern Africa)

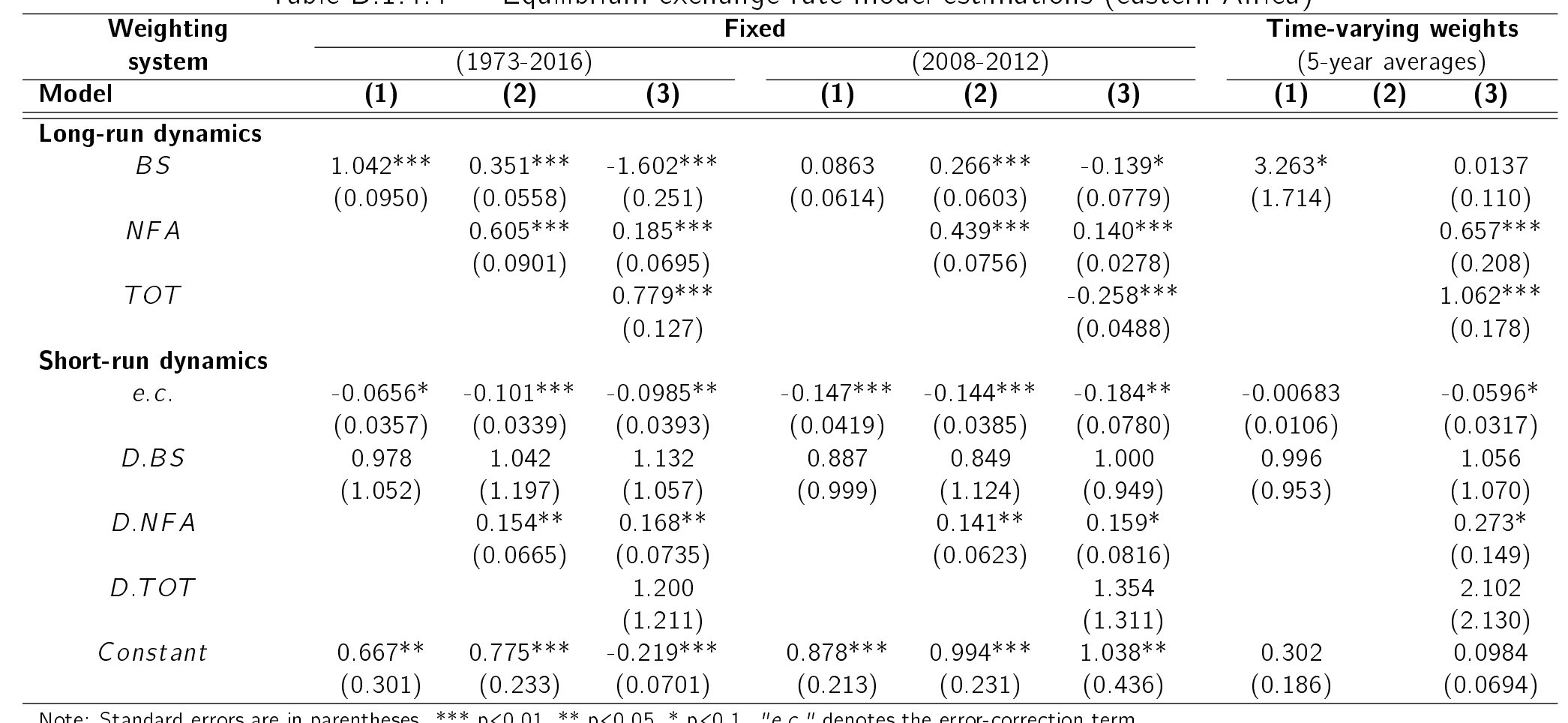


Table B.1.4.5 - Equilibrium exchange rate model estimations (eastern Asia)

\begin{tabular}{|c|c|c|c|c|c|c|c|c|c|}
\hline \multirow{3}{*}{$\begin{array}{l}\begin{array}{c}\text { Weighting } \\
\text { system }\end{array} \\
\text { Model } \\
\end{array}$} & \multicolumn{6}{|c|}{ Fixed } & \multirow{2}{*}{\multicolumn{3}{|c|}{$\begin{array}{c}\text { Time-varying weights } \\
\text { (5-year averages) }\end{array}$}} \\
\hline & \multicolumn{3}{|c|}{$(1973-2016)$} & \multicolumn{3}{|c|}{$(2008-2012)$} & & & \\
\hline & (1) & $(2)$ & (3) & (1) & $(2)$ & $(3)$ & (1) & (2) & (3) \\
\hline \multicolumn{10}{|c|}{ Long-run dynamics } \\
\hline$B S$ & $\begin{array}{c}0.566 * * * \\
(0.185)\end{array}$ & $\begin{array}{c}0.0436 \\
(0.0873)\end{array}$ & $\begin{array}{c}0.157^{*} \\
(0.0860)\end{array}$ & $\begin{array}{c}0.545^{* * *} \\
(0.168)\end{array}$ & $\begin{array}{c}0.261^{* * *} \\
(0.100)\end{array}$ & $\begin{array}{l}0.256^{* * *} \\
(0.0950)\end{array}$ & $\begin{array}{c}0.596 * * * \\
(0.205)\end{array}$ & $\begin{array}{l}-0.0494 \\
(0.0434)\end{array}$ & $\begin{array}{c}0.0218 \\
(0.0375)\end{array}$ \\
\hline$N F A$ & & $\begin{array}{c}0.224 \\
(0.151)\end{array}$ & $\begin{array}{l}-0.0716 \\
(0.0692)\end{array}$ & & $\begin{array}{c}0.152 \\
(0.0943)\end{array}$ & $\begin{array}{l}-0.0226 \\
(0.0307)\end{array}$ & & $\begin{array}{l}0.197^{*} \\
(0.119)\end{array}$ & $\begin{array}{l}-0.0224 \\
(0.0340)\end{array}$ \\
\hline TOT & & & $\begin{array}{c}0.179 \\
(0.147)\end{array}$ & & & $\begin{array}{l}0.00329 \\
(0.0692)\end{array}$ & & & $\begin{array}{l}0.171^{* *} \\
(0.0743)\end{array}$ \\
\hline \multicolumn{10}{|c|}{ Short-run dynamics } \\
\hline e.c. & $\begin{array}{c}-0.0908^{* * *} \\
(0.0151)\end{array}$ & $\begin{array}{c}-0.175^{* * *} \\
(0.0569)\end{array}$ & $\begin{array}{c}-0.225^{* * *} \\
(0.0724)\end{array}$ & $\begin{array}{c}-0.118^{* * *} \\
(0.0330)\end{array}$ & $\begin{array}{c}-0.217^{* * *} \\
(0.0608)\end{array}$ & $\begin{array}{c}-0.327^{* *} \\
(0.146)\end{array}$ & $\begin{array}{c}-0.0945^{* * *} \\
(0.0285)\end{array}$ & $\begin{array}{c}-0.219 * * * \\
(0.0739)\end{array}$ & $\begin{array}{c}-0.264^{* *} \\
(0.108)\end{array}$ \\
\hline$D . B S$ & $\begin{array}{c}0.328^{* *} \\
(0.133)\end{array}$ & $\begin{array}{l}0.0971 \\
(0.388)\end{array}$ & $\begin{array}{c}0.265^{* * *} * \\
(0.0734)\end{array}$ & $\begin{array}{c}0.209 * * \\
(0.0926)\end{array}$ & $\begin{array}{l}0.0759 \\
(0.237)\end{array}$ & $\begin{array}{l}0.192^{* *} \\
(0.0805)\end{array}$ & $\begin{array}{c}0.306^{* *} \\
(0.121)\end{array}$ & $\begin{array}{c}0.143 \\
(0.247)\end{array}$ & $\begin{array}{l}0.289 * * * \\
(0.0497)\end{array}$ \\
\hline D.NFA & & $\begin{array}{l}-0.202^{*} \\
(0.112)\end{array}$ & $\begin{array}{l}-0.190 \\
(0.186)\end{array}$ & & $\begin{array}{c}-0.186 * * \\
(0.0891)\end{array}$ & $\begin{array}{l}-0.240 \\
(0.182)\end{array}$ & & $\begin{array}{c}-0.269 * * * \\
(0.0936)\end{array}$ & $\begin{array}{l}-0.266 \\
(0.167)\end{array}$ \\
\hline D.TOT & & & $\begin{array}{c}0.609 \\
(0.374)\end{array}$ & & & $\begin{array}{l}0.601^{*} \\
(0.344)\end{array}$ & & & $\begin{array}{l}0.639^{*} \\
(0.374)\end{array}$ \\
\hline Constant & $\begin{array}{l}0.422 * * * \\
(0.0756)\end{array}$ & $\begin{array}{c}0.827^{* * *} \\
(0.273)\end{array}$ & $\begin{array}{c}0.872 * * * \\
(0.279)\end{array}$ & $\begin{array}{c}0.543^{* * *} \\
(0.155)\end{array}$ & $\begin{array}{c}1.025 * * * \\
(0.297)\end{array}$ & $\begin{array}{l}1.532^{* *} \\
(0.692)\end{array}$ & $\begin{array}{c}0.418^{* * *} \\
(0.123)\end{array}$ & $\begin{array}{c}1.018^{* * *} \\
(0.355)\end{array}$ & $\begin{array}{l}1.010 * * \\
(0.407)\end{array}$ \\
\hline
\end{tabular}

Note: Standard errors are in parentheses. ${ }^{* * *} \mathrm{p}<0.01, * * \mathrm{p}<0.05, * \mathrm{p}<0.1$. "e.c." denotes the error-correction term. 
Table B.1.4.6 - Equilibrium exchange rate model estimations (eastern Europe)

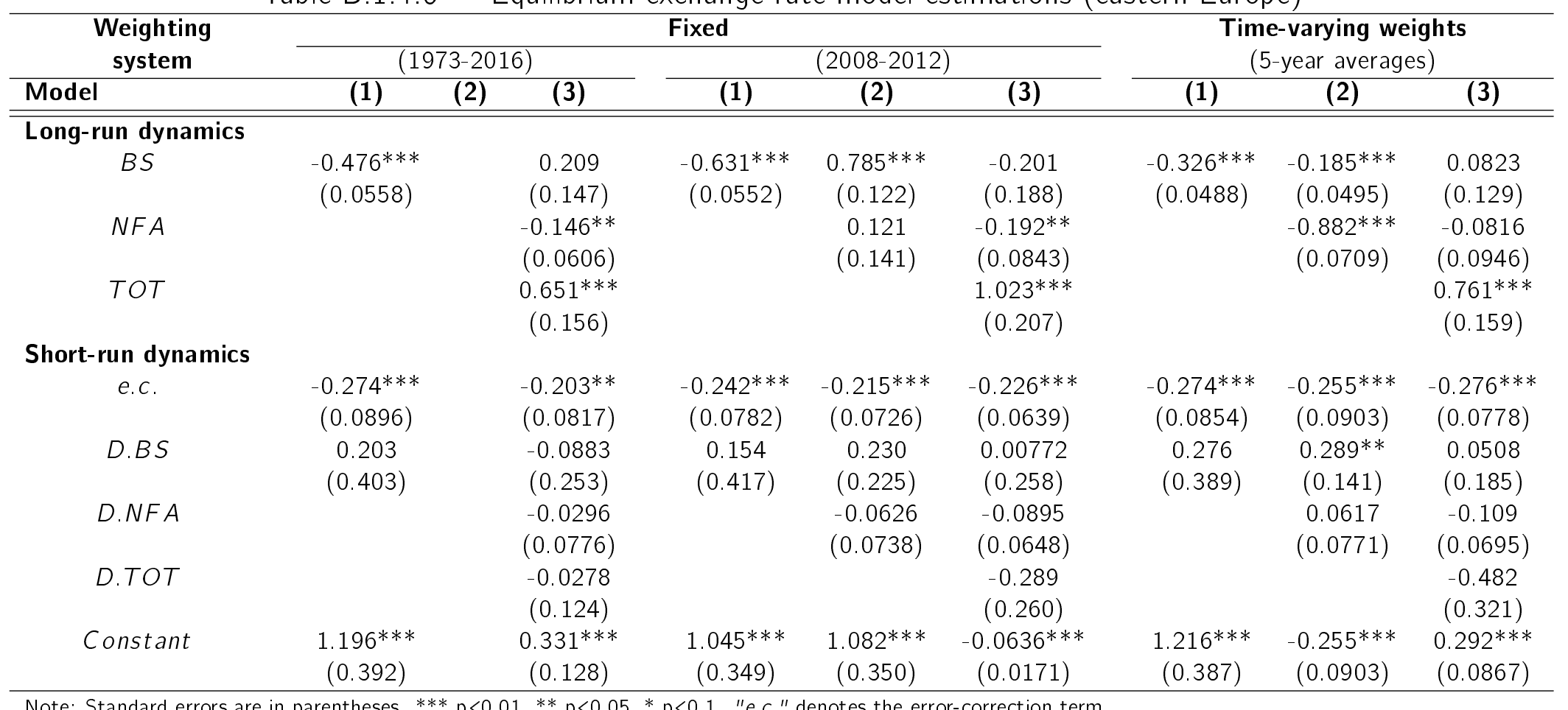


Table B.1.4.7 - Equilibrium exchange rate model estimations (middle Africa)

\begin{tabular}{|c|c|c|c|c|c|c|c|c|c|}
\hline \multirow{3}{*}{$\begin{array}{c}\begin{array}{c}\text { Weighting } \\
\text { system }\end{array} \\
\text { Model }\end{array}$} & \multicolumn{6}{|c|}{ Fixed } & \multirow{2}{*}{\multicolumn{3}{|c|}{$\begin{array}{c}\text { Time-varying weights } \\
\text { (5-year averages) }\end{array}$}} \\
\hline & \multicolumn{3}{|c|}{ (1973-2016) } & \multicolumn{3}{|c|}{$(2008-2012)$} & & & \\
\hline & (1) & (2) & (3) & (1) & $(2)$ & (3) & (1) & $(2)$ & (3) \\
\hline \multicolumn{10}{|c|}{ Long-run dynamics } \\
\hline$B S$ & $\begin{array}{l}0.218^{* *} \\
(0.0878)\end{array}$ & $\begin{array}{l}-0.318 \\
(0.557)\end{array}$ & $\begin{array}{l}0.201 * * * \\
(0.0490)\end{array}$ & $\begin{array}{c}0.166^{*} \\
(0.0895)\end{array}$ & $\begin{array}{c}0.126 \\
(0.0799)\end{array}$ & $\begin{array}{l}0.396 * * * \\
(0.0666)\end{array}$ & $\begin{array}{l}0.271^{* *} \\
(0.123)\end{array}$ & $\begin{array}{r}-0.0192 \\
(0.692)\end{array}$ & $\begin{array}{l}0.276 * * * \\
(0.0476)\end{array}$ \\
\hline$N F A$ & & $\begin{array}{c}-1.331 \\
(0.999)\end{array}$ & $\begin{array}{c}0.129 * * * \\
(0.0261)\end{array}$ & & $\begin{array}{l}0.169 * * * \\
(0.0365)\end{array}$ & $\begin{array}{c}0.0913 * * * \\
(0.0261)\end{array}$ & & $\begin{array}{l}-1.416 \\
(1.180)\end{array}$ & $\begin{array}{l}0.155^{* * *} \\
(0.0294)\end{array}$ \\
\hline TOT & & & $\begin{array}{l}-0.0550 \\
(0.0495)\end{array}$ & & & $\begin{array}{c}0.264^{* * *} \\
(0.0909)\end{array}$ & & & $\begin{array}{c}-0.304 * * * \\
(0.0584)\end{array}$ \\
\hline \multicolumn{10}{|c|}{ Short-run dynamics } \\
\hline e.c. & $\begin{array}{c}-0.263^{* *} \\
(0.106)\end{array}$ & $\begin{array}{l}-0.116 \\
(0.121)\end{array}$ & $\begin{array}{c}-0.365^{* * *} \\
(0.0928)\end{array}$ & $\begin{array}{c}-0.264 * * \\
(0.106)\end{array}$ & $\begin{array}{c}-0.294 * * * \\
(0.102)\end{array}$ & $\begin{array}{c}-0.270 * * \\
(0.111)\end{array}$ & $\begin{array}{c}-0.249 * * \\
(0.106)\end{array}$ & $\begin{array}{l}-0.120 \\
(0.121)\end{array}$ & $\begin{array}{c}-0.328 * * * \\
(0.101)\end{array}$ \\
\hline$D . B S$ & $\begin{array}{r}-0.0527 \\
(0.244)\end{array}$ & $\begin{array}{l}-0.0912 \\
(0.0836)\end{array}$ & $\begin{array}{c}-0.313 * * \\
(0.147)\end{array}$ & $\begin{array}{l}-0.0287 \\
(0.290)\end{array}$ & $\begin{array}{c}-0.393 * * \\
(0.158)\end{array}$ & $\begin{array}{c}-0.420 * * \\
(0.182)\end{array}$ & $\begin{array}{l}-0.0222 \\
(0.226)\end{array}$ & $\begin{array}{l}0.00829 \\
(0.0882)\end{array}$ & $\begin{array}{l}-0.136 \\
(0.126)\end{array}$ \\
\hline$D . N F A$ & & $\begin{array}{l}0.136 * * \\
(0.0633)\end{array}$ & $\begin{array}{l}-0.0268 \\
(0.0422)\end{array}$ & & $\begin{array}{c}0.0256 \\
(0.0537)\end{array}$ & $\begin{array}{c}0.0212 \\
(0.0614)\end{array}$ & & $\begin{array}{l}0.133 * * \\
(0.0640)\end{array}$ & $\begin{array}{l}-0.0280 \\
(0.0491)\end{array}$ \\
\hline D.TOT & & & $\begin{array}{c}0.0904 \\
(0.124)\end{array}$ & & & $\begin{array}{c}0.0137 \\
(0.106)\end{array}$ & & & $\begin{array}{c}0.133 \\
(0.124)\end{array}$ \\
\hline Constant & $\begin{array}{l}1.390 * * \\
(0.590)\end{array}$ & $\begin{array}{c}0.371 \\
(0.382)\end{array}$ & $\begin{array}{c}2.076 * * * \\
(0.603)\end{array}$ & $\begin{array}{l}1.358 * * \\
(0.577)\end{array}$ & $\begin{array}{c}1.515 * * * \\
(0.553)\end{array}$ & $\begin{array}{l}1.281^{* *} \\
(0.606)\end{array}$ & $\begin{array}{l}1.357^{* *} \\
(0.607)\end{array}$ & $\begin{array}{c}0.487 \\
(0.484)\end{array}$ & $\begin{array}{c}2.291^{* * *} \\
(0.778)\end{array}$ \\
\hline
\end{tabular}

Note: Standard errors are in parentheses. ${ }^{* * *} \mathrm{p}<0.01,{ }^{* *} \mathrm{p}<0.05, * \mathrm{p}<0.1$. "e.c." denotes the error-correction term. 
Table B.1.4.8 - Equilibrium exchange rate model estimations (northern Africa)

\begin{tabular}{|c|c|c|c|c|c|c|c|c|c|}
\hline \multirow{3}{*}{$\begin{array}{l}\begin{array}{c}\text { Weighting } \\
\text { system }\end{array} \\
\text { Model }\end{array}$} & \multicolumn{6}{|c|}{ Fixed } & \multirow{2}{*}{\multicolumn{3}{|c|}{$\begin{array}{c}\text { Time-varying weights } \\
\text { (5-year averages) }\end{array}$}} \\
\hline & \multicolumn{3}{|c|}{$(1973-2016)$} & \multicolumn{3}{|c|}{$(2008-2012)$} & & & \\
\hline & (1) & $(2)$ & (3) & (1) & $(2)$ & (3) & (1) & $(2)$ & (3) \\
\hline \multicolumn{10}{|c|}{ Long-run dynamics } \\
\hline$B S$ & $\begin{array}{c}1.309 * * * \\
(0.135)\end{array}$ & $\begin{array}{c}1.262^{* * *} \\
(0.116)\end{array}$ & $\begin{array}{c}0.903 * * * \\
(0.132)\end{array}$ & $\begin{array}{c}1.196 * * * \\
(0.115)\end{array}$ & $\begin{array}{l}1.158 * * * \\
(0.0974)\end{array}$ & $\begin{array}{c}1.052 * * * \\
(0.126)\end{array}$ & $\begin{array}{c}1.510^{* * *} \\
(0.247)\end{array}$ & $\begin{array}{c}1.223 * * * \\
(0.179)\end{array}$ & $\begin{array}{c}0.853 * * * \\
(0.136)\end{array}$ \\
\hline$N F A$ & & $\begin{array}{l}-0.0378 \\
(0.0372)\end{array}$ & $\begin{array}{c}-0.0918 * * * \\
(0.0171)\end{array}$ & & $\begin{array}{l}-0.0434 \\
(0.0325)\end{array}$ & $\begin{array}{c}-0.0965 * * * \\
(0.0174)\end{array}$ & & $\begin{array}{l}-0.0413 \\
(0.0346)\end{array}$ & $\begin{array}{c}-0.0899 * * * \\
(0.0172)\end{array}$ \\
\hline TOT & & & $\begin{array}{c}0.394 * * * \\
(0.0959)\end{array}$ & & & $\begin{array}{c}0.363^{* * *} \\
(0.0978)\end{array}$ & & & $\begin{array}{c}0.405^{* * *} \\
(0.0957)\end{array}$ \\
\hline \multicolumn{10}{|c|}{ Short-run dynamics } \\
\hline e.c. & $\begin{array}{c}-0.159 * * \\
(0.0665)\end{array}$ & $\begin{array}{c}-0.182^{* *} \\
(0.0847)\end{array}$ & $\begin{array}{l}-0.270^{*} \\
(0.162)\end{array}$ & $\begin{array}{l}-0.186^{*} \\
(0.0986)\end{array}$ & $\begin{array}{l}-0.180^{*} \\
(0.0953)\end{array}$ & $\begin{array}{l}-0.257 \\
(0.169)\end{array}$ & $\begin{array}{c}-0.130 * * \\
(0.0632)\end{array}$ & $\begin{array}{l}-0.163^{*} \\
(0.0915)\end{array}$ & $\begin{array}{l}-0.262 \\
(0.162)\end{array}$ \\
\hline$D . B S$ & $\begin{array}{c}-0.0261 \\
(0.140)\end{array}$ & $\begin{array}{l}-0.0755 \\
(0.201)\end{array}$ & $\begin{array}{l}-0.168 \\
(0.282)\end{array}$ & $\begin{array}{r}-0.0938 \\
(0.199)\end{array}$ & $\begin{array}{l}-0.0729 \\
(0.208)\end{array}$ & $\begin{array}{l}-0.214 \\
(0.281)\end{array}$ & $\begin{array}{c}-0.00748 \\
(0.143)\end{array}$ & $\begin{array}{r}-0.0672 \\
(0.190)\end{array}$ & $\begin{array}{l}-0.148 \\
(0.292)\end{array}$ \\
\hline$D . N F A$ & & $\begin{array}{c}0.118 \\
(0.149)\end{array}$ & $\begin{array}{c}0.0632 \\
(0.0936)\end{array}$ & & $\begin{array}{c}0.134 \\
(0.160)\end{array}$ & $\begin{array}{l}0.0963 \\
(0.107)\end{array}$ & & $\begin{array}{c}0.111 \\
(0.136)\end{array}$ & $\begin{array}{c}0.0697 \\
(0.0951)\end{array}$ \\
\hline D.TOT & & & $\begin{array}{c}-0.304 * * \\
(0.154)\end{array}$ & & & $\begin{array}{l}-0.292^{*} \\
(0.156)\end{array}$ & & & $\begin{array}{c}-0.317 * * \\
(0.153)\end{array}$ \\
\hline Constant & $\begin{array}{l}1.023 * * \\
(0.459)\end{array}$ & $\begin{array}{l}1.155^{* *} \\
(0.571)\end{array}$ & $\begin{array}{c}1.108 \\
(0.713)\end{array}$ & $\begin{array}{c}0.996 * \\
(0.513)\end{array}$ & $\begin{array}{c}1.145^{*} \\
(0.640)\end{array}$ & $\begin{array}{c}1.143 \\
(0.807)\end{array}$ & $\begin{array}{l}0.875^{*} \\
(0.468)\end{array}$ & $\begin{array}{c}1.036 * \\
(0.618)\end{array}$ & $\begin{array}{c}1.048 \\
(0.694)\end{array}$ \\
\hline
\end{tabular}


Table B.1.4.9 - Equilibrium exchange rate model estimations (northern Europe)

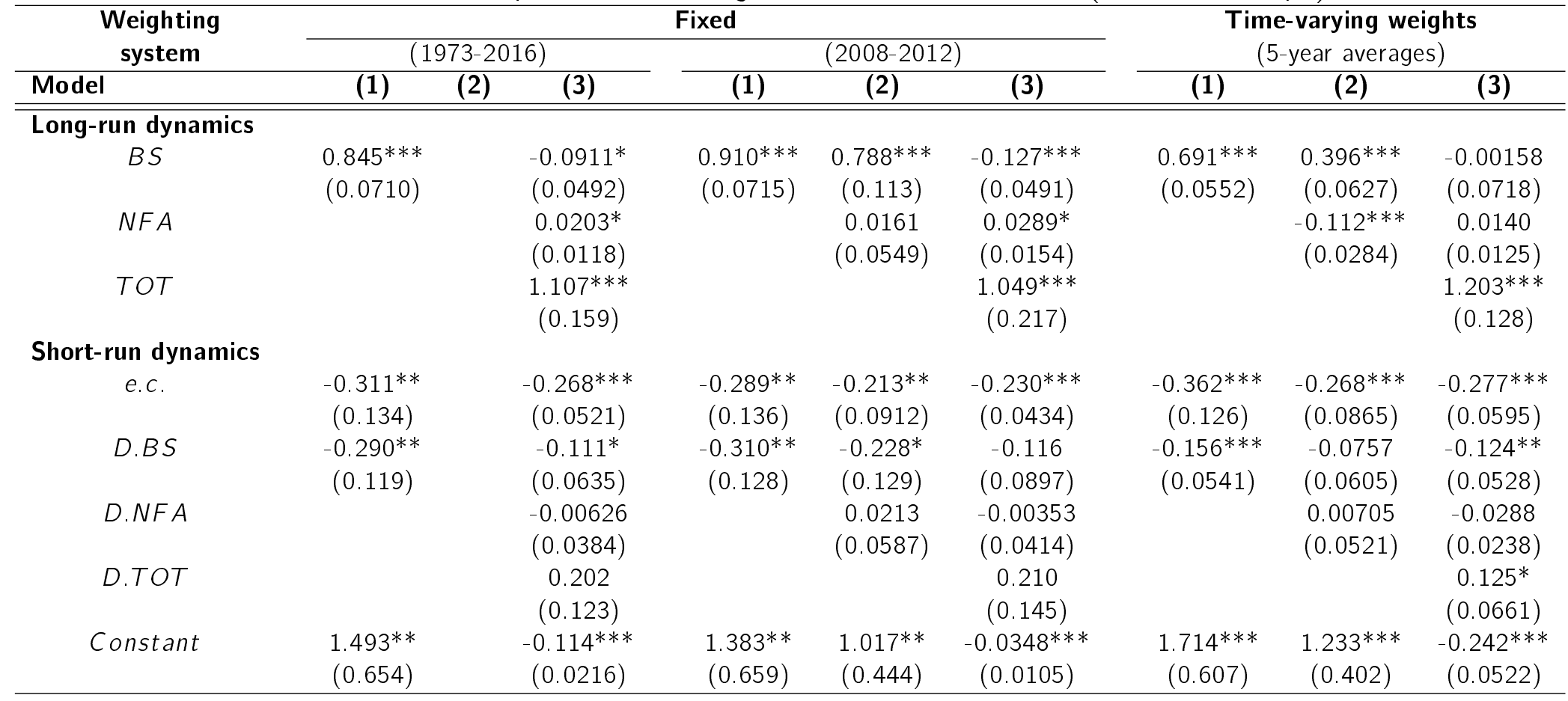

Note: Standard errors are in parentheses. ${ }^{* * *} \mathrm{p}<0.01,{ }^{* *} \mathrm{p}<0.05, * \mathrm{p}<0.1$. "e.c." denotes the error-correction term. 
Table B.1.4.10 - Equilibrium exchange rate model estimations (south America)

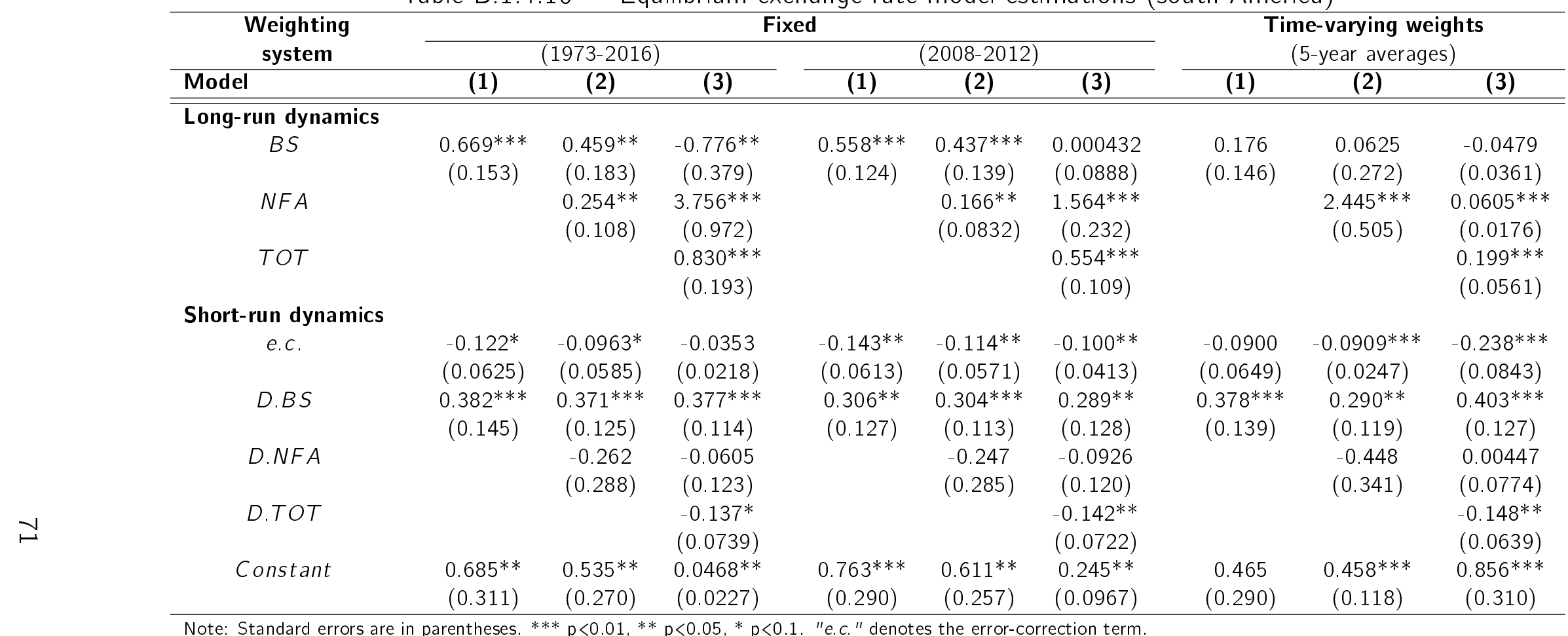


Table B.1.4.11 — Equilibrium exchange rate model estimations (south eastern Asia)

\begin{tabular}{|c|c|c|c|c|c|c|c|c|c|}
\hline \multirow{3}{*}{$\begin{array}{c}\begin{array}{c}\text { Weighting } \\
\text { system }\end{array} \\
\text { Model }\end{array}$} & \multicolumn{6}{|c|}{ Fixed } & \multirow{2}{*}{\multicolumn{3}{|c|}{$\begin{array}{l}\text { Time-varying weights } \\
\text { (5-year averages) }\end{array}$}} \\
\hline & \multicolumn{3}{|c|}{$(1973-2016)$} & \multicolumn{3}{|c|}{$(2008-2012)$} & & & \\
\hline & (1) & (2) & (3) & (1) & (2) & (3) & (1) & (2) & (3) \\
\hline \multicolumn{10}{|c|}{ Long-run dynamics } \\
\hline$B S$ & $\begin{array}{c}-4.751^{* * *} \\
(1.534)\end{array}$ & $\begin{array}{l}-3.770 \\
(5.133)\end{array}$ & $\begin{array}{l}0.0823 \\
(0.163)\end{array}$ & $\begin{array}{c}-0.167^{* * *} \\
(0.0425)\end{array}$ & $\begin{array}{l}-2.566 \\
(2.673)\end{array}$ & $\begin{array}{l}-0.147 \\
(0.165)\end{array}$ & $\begin{array}{c}-4.246 * * * \\
(1.333)\end{array}$ & $\begin{array}{l}-3.285 \\
(2.203)\end{array}$ & $\begin{array}{c}0.420^{* * *} \\
(0.0717)\end{array}$ \\
\hline NFA & & $\begin{array}{l}-6.272 \\
(8.009)\end{array}$ & $\begin{array}{c}-0.160 * * * \\
(0.0594)\end{array}$ & & $\begin{array}{l}-4.762 \\
(4.229)\end{array}$ & $\begin{array}{c}-0.165^{* *} \\
(0.0756)\end{array}$ & & $\begin{array}{l}-2.401 \\
(1.526)\end{array}$ & $\begin{array}{l}-0.163 * \\
(0.0853)\end{array}$ \\
\hline TOT & & & $\begin{array}{c}-0.948 * * * \\
(0.224)\end{array}$ & & & $\begin{array}{c}-1.148 * * * \\
(0.320)\end{array}$ & & & $\begin{array}{l}0.0931 \\
(0.132)\end{array}$ \\
\hline \multicolumn{10}{|c|}{ Short-run dynamics } \\
\hline e.c. & $\begin{array}{c}-0.0536^{* *} \\
(0.0249)\end{array}$ & $\begin{array}{r}-0.000169 \\
(0.00584)\end{array}$ & $\begin{array}{r}-0.0747^{*} \\
(0.0408)\end{array}$ & $\begin{array}{c}-0.135 * * * \\
(0.0333)\end{array}$ & $\begin{array}{l}0.000118 \\
(0.00819)\end{array}$ & $\begin{array}{l}-0.0550^{*} \\
(0.0327)\end{array}$ & $\begin{array}{c}-0.0506^{* *} \\
(0.0256)\end{array}$ & $\begin{array}{c}-0.00656 \\
(0.0134)\end{array}$ & $\begin{array}{l}-0.0922 \\
(0.0698)\end{array}$ \\
\hline D.BS & $\begin{array}{c}0.689 * * * \\
(0.207)\end{array}$ & $\begin{array}{l}0.0949 \\
(0.223)\end{array}$ & $\begin{array}{l}0.0409 \\
(0.230)\end{array}$ & $\begin{array}{c}0.221 \\
(0.210)\end{array}$ & $\begin{array}{l}0.0406 \\
(0.195)\end{array}$ & $\begin{array}{r}-0.0314 \\
(0.222)\end{array}$ & $\begin{array}{c}0.732 * * * \\
(0.222)\end{array}$ & $\begin{array}{l}0.213^{* *} \\
(0.103)\end{array}$ & $\begin{array}{l}0.00979 \\
(0.157)\end{array}$ \\
\hline D.NFA & & $\begin{array}{c}0.0904 \\
(0.0977)\end{array}$ & $\begin{array}{c}0.120 \\
(0.0738)\end{array}$ & & $\begin{array}{l}0.0783 \\
(0.101)\end{array}$ & $\begin{array}{c}0.121 \\
(0.0758)\end{array}$ & & $\begin{array}{l}0.0786 \\
(0.104)\end{array}$ & $\begin{array}{c}0.0993 \\
(0.0832)\end{array}$ \\
\hline D.TOT & & & $\begin{array}{c}0.0306 \\
(0.0975)\end{array}$ & & & $\begin{array}{c}0.0110 \\
(0.0937)\end{array}$ & & & $\begin{array}{l}0.0123 \\
(0.122)\end{array}$ \\
\hline Constant & $\begin{array}{c}-0.0536^{* *} \\
(0.0249)\end{array}$ & $\begin{array}{l}-0.0410 \\
(0.0585)\end{array}$ & $\begin{array}{l}0.666^{*} \\
(0.367)\end{array}$ & $\begin{array}{c}0.580 * * * \\
(0.163)\end{array}$ & $\begin{array}{l}-0.0420 \\
(0.0511)\end{array}$ & $\begin{array}{l}0.520 * \\
(0.314)\end{array}$ & $\begin{array}{l}-0.284^{*} \\
(0.167)\end{array}$ & $\begin{array}{l}-0.103 \\
(0.0988)\end{array}$ & $\begin{array}{c}0.442 \\
(0.342)\end{array}$ \\
\hline
\end{tabular}

Note: Standard errors are in parentheses. $* * * p<0.01,{ }^{* *} \mathrm{p}<0.05, * \mathrm{p}<0.1$. "e.c." denotes the error-correction term. 
Table B.1.4.12 - Equilibrium exchange rate model estimations (southern Africa)

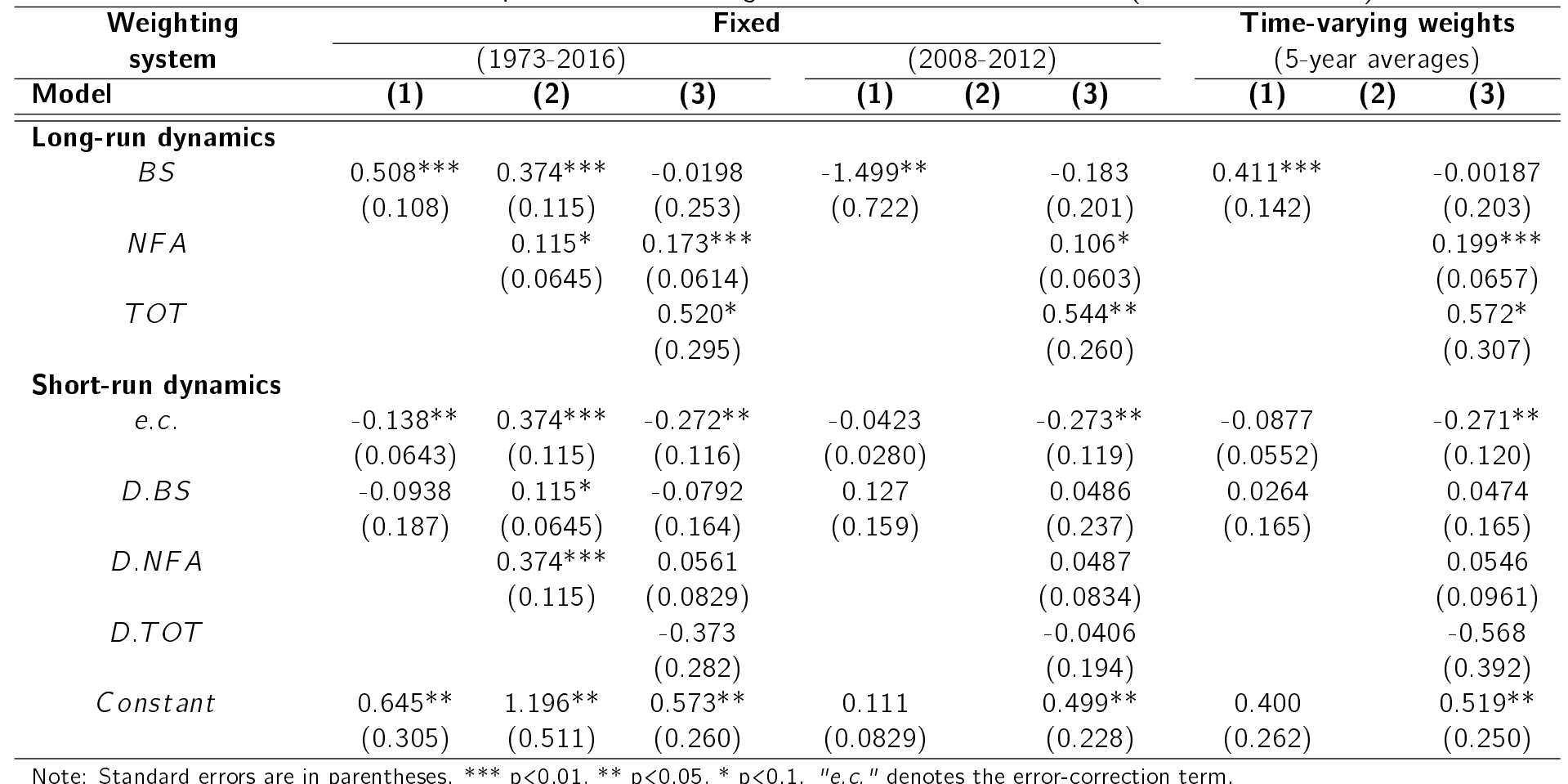


Table B.1.4.13 - Equilibrium exchange rate model estimations (southern Asia)

\begin{tabular}{|c|c|c|c|c|c|c|c|c|c|}
\hline \multirow{3}{*}{$\begin{array}{c}\begin{array}{c}\text { Weighting } \\
\text { system }\end{array} \\
\text { Model }\end{array}$} & \multicolumn{6}{|c|}{ Fixed } & \multirow{2}{*}{\multicolumn{3}{|c|}{$\begin{array}{c}\text { Time-varying weights } \\
\text { (5-year averages) }\end{array}$}} \\
\hline & \multicolumn{3}{|c|}{ (1973-2016) } & \multicolumn{3}{|c|}{$(2008-2012)$} & & & \\
\hline & (1) & (2) & (3) & (1) & (2) & (3) & (1) & $(2)$ & (3) \\
\hline \multicolumn{10}{|c|}{ Long-run dynamics } \\
\hline$B S$ & $\begin{array}{l}0.243^{* *} \\
(0.101)\end{array}$ & $\begin{array}{c}0.128 \\
(0.114)\end{array}$ & $\begin{array}{c}0.210 \\
(0.165)\end{array}$ & $\begin{array}{c}0.179 * \\
(0.0951)\end{array}$ & $\begin{array}{c}0.0940 \\
(0.0727)\end{array}$ & $\begin{array}{c}0.188 \\
(0.165)\end{array}$ & $\begin{array}{c}0.368 * * * \\
(0.112)\end{array}$ & $\begin{array}{c}0.442 * * * \\
(0.131)\end{array}$ & $\begin{array}{c}0.259 \\
(0.203)\end{array}$ \\
\hline$N F A$ & & $\begin{array}{l}0.0335^{* *} \\
(0.0171)\end{array}$ & $\begin{array}{l}-0.0825^{*} \\
(0.0485)\end{array}$ & & $\begin{array}{l}0.364 * * * \\
(0.0767)\end{array}$ & $\begin{array}{l}-0.0484 \\
(0.0383)\end{array}$ & & $\begin{array}{c}0.654 * * * \\
(0.219)\end{array}$ & $\begin{array}{c}0.0310 \\
(0.0260)\end{array}$ \\
\hline TOT & & & $\begin{array}{c}1.088 * * * \\
(0.288)\end{array}$ & & & $\begin{array}{c}1.023 * * * \\
(0.255)\end{array}$ & & & $\begin{array}{l}-0.183 \\
(0.255)\end{array}$ \\
\hline \multicolumn{10}{|c|}{ Short-run dynamics } \\
\hline e.c. & $\begin{array}{c}-0.294 * * * \\
(0.110)\end{array}$ & $\begin{array}{c}-0.330 * * \\
(0.146)\end{array}$ & $\begin{array}{l}-0.164^{*} \\
(0.0851)\end{array}$ & $\begin{array}{c}-0.284 * * * \\
(0.103)\end{array}$ & $\begin{array}{l}-0.229 * * \\
(0.0953)\end{array}$ & $\begin{array}{l}-0.194^{*} \\
(0.103)\end{array}$ & $\begin{array}{c}-0.296 * * * \\
(0.112)\end{array}$ & $\begin{array}{l}-0.186 * * \\
(0.0798)\end{array}$ & $\begin{array}{c}-0.263^{* *} \\
(0.116)\end{array}$ \\
\hline$D . B S$ & $\begin{array}{c}-0.00950 \\
(0.117)\end{array}$ & $\begin{array}{c}-0.0483 \\
(0.129)\end{array}$ & $\begin{array}{c}0.0746 \\
(0.0925)\end{array}$ & $\begin{array}{c}-0.00238 \\
(0.116)\end{array}$ & $\begin{array}{c}0.0379 \\
(0.156)\end{array}$ & $\begin{array}{c}0.162 \\
(0.139)\end{array}$ & $\begin{array}{l}-0.0141 \\
(0.0936)\end{array}$ & $\begin{array}{c}0.00356 \\
(0.113)\end{array}$ & $\begin{array}{c}0.0112 \\
(0.120)\end{array}$ \\
\hline$D . N F A$ & & $\begin{array}{l}0.304 * * * \\
(0.0649)\end{array}$ & $\begin{array}{c}0.183 \\
(0.149)\end{array}$ & & $\begin{array}{l}0.243 * * * \\
(0.0715)\end{array}$ & $\begin{array}{c}0.203 \\
(0.147)\end{array}$ & & $\begin{array}{l}0.179 * * \\
(0.0841)\end{array}$ & $\begin{array}{c}0.155 \\
(0.142)\end{array}$ \\
\hline D.TOT & & & $\begin{array}{l}0.00678 \\
(0.0993)\end{array}$ & & & $\begin{array}{c}0.0169 \\
(0.101)\end{array}$ & & & $\begin{array}{c}0.121 \\
(0.109)\end{array}$ \\
\hline Constant & $\begin{array}{c}1.444^{* * *} \\
(0.535)\end{array}$ & $\begin{array}{l}1.571^{* *} \\
(0.694)\end{array}$ & $\begin{array}{c}-0.0320^{*} \\
(0.0171)\end{array}$ & $\begin{array}{c}1.368^{* * *} * \\
(0.492)\end{array}$ & $\begin{array}{l}1.100 * * \\
(0.458)\end{array}$ & $\begin{array}{c}0.0161 \\
(0.0201)\end{array}$ & $\begin{array}{c}1.499 * * * \\
(0.559)\end{array}$ & $\begin{array}{c}0.991^{* *} \\
(0.419)\end{array}$ & $\begin{array}{l}1.508 * * \\
(0.672)\end{array}$ \\
\hline
\end{tabular}

Note: Standard errors are in parentheses. ${ }^{* * *} \mathrm{p}<0.01, * * \mathrm{p}<0.05, * \mathrm{p}<0.1$. "e.c." denotes the error-correction term. 
Table B.1.4.14 - Equilibrium exchange rate model estimations (southern Europe)

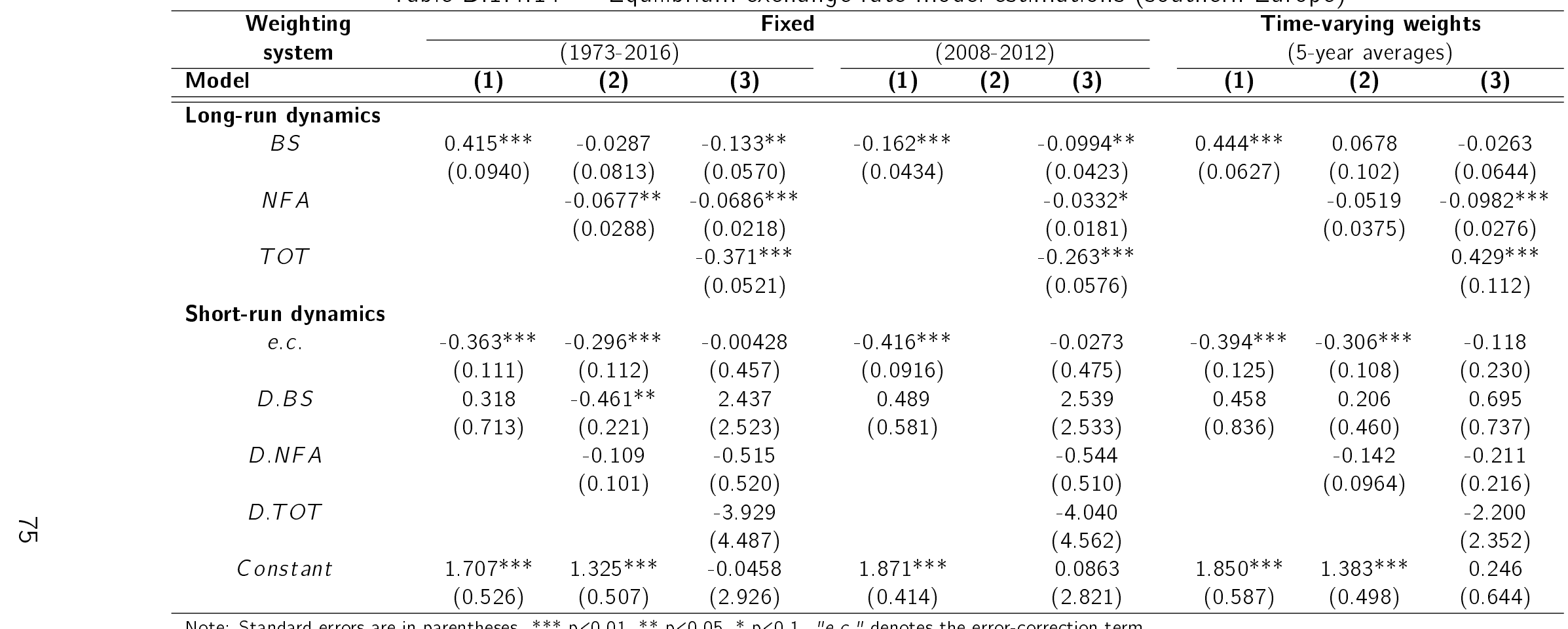


Table B.1.4.15 - Equilibrium exchange rate model estimations (western Africa)

\begin{tabular}{|c|c|c|c|c|c|c|c|c|c|}
\hline \multirow{2}{*}{$\begin{array}{c}\begin{array}{c}\text { Weighting } \\
\text { system }\end{array} \\
\end{array}$} & \multicolumn{6}{|c|}{ Fixed } & \multirow{2}{*}{\multicolumn{3}{|c|}{$\begin{array}{c}\text { Time-varying weights } \\
\text { (5-year averages) }\end{array}$}} \\
\hline & \multicolumn{3}{|c|}{$(1973-2016)$} & \multicolumn{3}{|c|}{$(2008-2012)$} & & & \\
\hline Model & (1) & $(2)$ & (3) & (1) & (2) & (3) & (1) & $(2)$ & (3) \\
\hline \multicolumn{10}{|c|}{ Long-run dynamics } \\
\hline$B S$ & $\begin{array}{c}-0.210^{* * *} \\
(0.0474)\end{array}$ & $\begin{array}{c}-0.707^{* * *} \\
(0.0977)\end{array}$ & $\begin{array}{c}-0.386^{* * *} \\
(0.0829)\end{array}$ & $\begin{array}{c}-0.288^{* * *} \\
(0.0557)\end{array}$ & $\begin{array}{c}-0.712^{* * *} \\
(0.0957)\end{array}$ & $\begin{array}{c}-0.398 * * * \\
(0.0752)\end{array}$ & $\begin{array}{c}-0.178^{* * *} \\
(0.0585)\end{array}$ & $\begin{array}{c}-0.692^{* * *} \\
(0.0995)\end{array}$ & $\begin{array}{c}-0.519 * * * \\
(0.0582)\end{array}$ \\
\hline$N F A$ & & $\begin{array}{c}0.0519 * * * \\
(0.0116)\end{array}$ & $\begin{array}{c}0.0101 \\
(0.0180)\end{array}$ & & $\begin{array}{c}0.0525^{* * * *} \\
(0.0114)\end{array}$ & $\begin{array}{l}0.00990 \\
(0.0162)\end{array}$ & & $\begin{array}{c}0.0506 * * * \\
(0.0117)\end{array}$ & $\begin{array}{l}0.0252 * \\
(0.0129)\end{array}$ \\
\hline TOT & & & $\begin{array}{c}1.432 * * * \\
(0.255)\end{array}$ & & & $\begin{array}{c}1.159 * * * \\
(0.182)\end{array}$ & & & $\begin{array}{c}0.849 * * * \\
(0.126)\end{array}$ \\
\hline \multicolumn{10}{|c|}{ Short-run dynamics } \\
\hline e.c. & $\begin{array}{c}-0.202^{* * *} \\
(0.0466)\end{array}$ & $\begin{array}{l}-0.114 * * \\
(0.0529)\end{array}$ & $\begin{array}{c}-0.0913 * * * \\
(0.0279)\end{array}$ & $\begin{array}{c}-0.190^{* * *} \\
(0.0458)\end{array}$ & $\begin{array}{l}-0.131 * * \\
(0.0560)\end{array}$ & $\begin{array}{c}-0.108 * * * \\
(0.0327)\end{array}$ & $\begin{array}{c}-0.205^{* * *} \\
(0.0457)\end{array}$ & $\begin{array}{r}-0.123^{* *} \\
(0.0536)\end{array}$ & $\begin{array}{c}-0.118^{* * *} \\
(0.0345)\end{array}$ \\
\hline$D . B S$ & $\begin{array}{c}-0.394^{*} \\
(0.236)\end{array}$ & $\begin{array}{c}-0.409 * \\
(0.231)\end{array}$ & $\begin{array}{l}-0.515^{*} \\
(0.274)\end{array}$ & $\begin{array}{c}-0.211^{*} \\
(0.120)\end{array}$ & $\begin{array}{c}-0.199 * \\
(0.110)\end{array}$ & $\begin{array}{c}-0.279 * \\
(0.144)\end{array}$ & $\begin{array}{l}-0.115 \\
(0.102)\end{array}$ & $\begin{array}{c}-0.118 \\
(0.0921)\end{array}$ & $\begin{array}{l}-0.184 \\
(0.154)\end{array}$ \\
\hline D.NFA & & $\begin{array}{l}0.227 * * * \\
(0.0641)\end{array}$ & $\begin{array}{l}0.267 * * * \\
(0.0775)\end{array}$ & & $\begin{array}{l}0.194^{* * *} \\
(0.0600)\end{array}$ & $\begin{array}{l}0.243^{* * *} \\
(0.0653)\end{array}$ & & $\begin{array}{l}0.195^{* * *} \\
(0.0564)\end{array}$ & $\begin{array}{l}0.200^{* * *} \\
(0.0548)\end{array}$ \\
\hline D.TOT & & & $\begin{array}{l}-0.194 * * \\
(0.0926)\end{array}$ & & & $\begin{array}{l}-0.140 * * \\
(0.0617)\end{array}$ & & & $\begin{array}{l}-0.229 \\
(0.162)\end{array}$ \\
\hline Constant & $\begin{array}{c}0.811^{* * *} \\
(0.165)\end{array}$ & $\begin{array}{c}0.317 * * * \\
(0.120)\end{array}$ & $\begin{array}{c}-0.242 * * * \\
(0.0761)\end{array}$ & $\begin{array}{c}0.735^{* * *} \\
(0.150)\end{array}$ & $\begin{array}{c}0.372^{* * *} \\
(0.132)\end{array}$ & $\begin{array}{c}0.584 * * * \\
(0.122)\end{array}$ & $\begin{array}{c}0.841^{* * *} \\
(0.167)\end{array}$ & $\begin{array}{c}0.351^{* * *} \\
(0.127)\end{array}$ & $\begin{array}{r}-0.0431^{* *} \\
(0.0212)\end{array}$ \\
\hline
\end{tabular}

Note: Standard errors are in parentheses. ${ }^{* * *} \mathrm{p}<0.01, * * \mathrm{p}<0.05, * \mathrm{p}<0.1$. "e.c." denotes the error-correction term. 
Table B.1.4.16 - Equilibrium exchange rate model estimations (western Asia)

\begin{tabular}{|c|c|c|c|c|c|c|c|c|c|}
\hline \multirow{2}{*}{$\begin{array}{c}\begin{array}{c}\text { Weighting } \\
\text { system }\end{array} \\
\text { Model }\end{array}$} & \multicolumn{6}{|c|}{ Fixed } & \multirow{2}{*}{\multicolumn{3}{|c|}{$\begin{array}{l}\text { Time-varying weights } \\
\text { (5-year averages) }\end{array}$}} \\
\hline & (1) & $\frac{1973-2016}{(2)}$ & (3) & (1) & $\frac{(2008-2012)}{(2)}$ & (3) & & & \\
\hline \multicolumn{10}{|c|}{ Long-run dynamics } \\
\hline$B S$ & $\begin{array}{l}0.397 * * * \\
(0.0405)\end{array}$ & $\begin{array}{c}0.174 \\
(0.189)\end{array}$ & $\begin{array}{l}-0.0694 \\
(0.0469)\end{array}$ & $\begin{array}{l}0.390 * * * \\
(0.0372)\end{array}$ & $\begin{array}{l}0.0252^{* * *} \\
(0.00764)\end{array}$ & $\begin{array}{l}-0.0662 \\
(0.0491)\end{array}$ & $\begin{array}{l}0.317 * * * \\
(0.0378)\end{array}$ & $\begin{array}{c}1.544 * * * \\
(0.404)\end{array}$ & $\begin{array}{l}-0.0218 \\
(0.0445)\end{array}$ \\
\hline$N F A$ & & $\begin{array}{c}3.722 * * * \\
(0.673)\end{array}$ & $\begin{array}{c}0.0720 * * * \\
(0.0148)\end{array}$ & & $\begin{array}{c}-0.0393 * * * \\
(0.0102)\end{array}$ & $\begin{array}{c}0.0959 * * * \\
(0.0187)\end{array}$ & & $\begin{array}{c}3.531 * * * \\
(0.496)\end{array}$ & $\begin{array}{c}0.0626 * * * \\
(0.0157)\end{array}$ \\
\hline TOT & & & $\begin{array}{c}0.593 * * * \\
(0.0714)\end{array}$ & & & $\begin{array}{c}0.691 * * * \\
(0.0845)\end{array}$ & & & $\begin{array}{c}0.547^{* * *} \\
(0.0759)\end{array}$ \\
\hline \multicolumn{10}{|c|}{ Short-run dynamics } \\
\hline e.c. & $\begin{array}{c}-0.204^{* * *} \\
(0.0745)\end{array}$ & $\begin{array}{l}-0.00729 \\
(0.0121)\end{array}$ & $\begin{array}{c}-0.305^{* * *} \\
(0.0718)\end{array}$ & $\begin{array}{c}-0.195^{* * *} \\
(0.0719)\end{array}$ & $\begin{array}{c}-0.192^{* * *} \\
(0.0569)\end{array}$ & $\begin{array}{c}-0.277^{* * *} \\
(0.0720)\end{array}$ & $\begin{array}{c}-0.220^{* * *} \\
(0.0769)\end{array}$ & $\begin{array}{l}-0.0131 \\
(0.0117)\end{array}$ & $\begin{array}{c}-0.296 * * * \\
(0.0826)\end{array}$ \\
\hline$D . B S$ & $\begin{array}{c}0.0140 \\
(0.0830)\end{array}$ & $\begin{array}{l}-0.0231 \\
(0.0609)\end{array}$ & $\begin{array}{c}0.00459 \\
(0.0694)\end{array}$ & $\begin{array}{c}0.0117 \\
(0.0949)\end{array}$ & $\begin{array}{l}-0.0420 \\
(0.0706)\end{array}$ & $\begin{array}{r}-0.00727 \\
(0.0564)\end{array}$ & $\begin{array}{c}0.0919 \\
(0.120)\end{array}$ & $\begin{array}{r}-0.00728 \\
(0.0596)\end{array}$ & $\begin{array}{c}0.0171 \\
(0.0567)\end{array}$ \\
\hline D.NFA & & $\begin{array}{c}0.0663 \\
(0.0608)\end{array}$ & $\begin{array}{c}0.0186 \\
(0.0672)\end{array}$ & & $\begin{array}{c}0.0960 * * \\
(0.0448)\end{array}$ & $\begin{array}{c}0.0110 \\
(0.0662)\end{array}$ & & $\begin{array}{c}0.0777 \\
(0.0530)\end{array}$ & $\begin{array}{c}0.0427 \\
(0.0626)\end{array}$ \\
\hline D.TOT & & & $\begin{array}{l}-0.158^{*} \\
(0.0914)\end{array}$ & & & $\begin{array}{r}-0.0680 \\
(0.118)\end{array}$ & & & $\begin{array}{c}-0.180^{* *} \\
(0.0797)\end{array}$ \\
\hline Constant & $\begin{array}{c}1.006 * * * \\
(0.367)\end{array}$ & $\begin{array}{c}0.0817 \\
(0.0730)\end{array}$ & $\begin{array}{c}0.569 * * * \\
(0.130)\end{array}$ & $\begin{array}{c}0.960 * * * \\
(0.354)\end{array}$ & $\begin{array}{c}0.886 * * * \\
(0.262)\end{array}$ & $\begin{array}{c}0.396 * * * \\
(0.101)\end{array}$ & $\begin{array}{c}1.065^{* * *} \\
(0.372)\end{array}$ & $\begin{array}{c}0.137 \\
(0.0928)\end{array}$ & $\begin{array}{c}0.619 * * * \\
(0.171)\end{array}$ \\
\hline
\end{tabular}


Table B.1.4.17 - Equilibrium exchange rate model estimations (western Europe)

\begin{tabular}{|c|c|c|c|c|c|c|}
\hline \multirow{3}{*}{$\begin{array}{l}\begin{array}{c}\text { Weighting } \\
\text { system }\end{array} \\
\text { Model }\end{array}$} & \multicolumn{4}{|c|}{ Fixed } & \multirow{2}{*}{\multicolumn{2}{|c|}{$\begin{array}{l}\text { Time-varying weights } \\
\text { (5-year averages) }\end{array}$}} \\
\hline & \multicolumn{2}{|c|}{$(1973-2016)$} & \multicolumn{2}{|c|}{$(2008-2012)$} & & \\
\hline & (1) & (2) (3) & (1) & (2) $\quad(3)$ & (1) & (2) (3) \\
\hline \multicolumn{7}{|c|}{ Long-run dynamics } \\
\hline$B S$ & $\begin{array}{c}-0.476 * * * \\
(0.0483)\end{array}$ & $\begin{array}{c}-0.565^{* * *} \\
(0.0661)\end{array}$ & $\begin{array}{c}-0.168 * * * \\
(0.0491)\end{array}$ & $\begin{array}{c}-0.165^{* * *} \\
(0.0409)\end{array}$ & $\begin{array}{c}-0.540 * * * \\
(0.0616)\end{array}$ & $\begin{array}{c}-0.727^{* * *} \\
(0.156)\end{array}$ \\
\hline NFA & & $\begin{array}{c}-0.301 * * * \\
(0.108)\end{array}$ & & $\begin{array}{c}-0.188 * * * \\
(0.0664)\end{array}$ & & $\begin{array}{c}-0.310 * * * \\
(0.0961)\end{array}$ \\
\hline TOT & & $\begin{array}{l}1.380^{* *} \\
(0.629)\end{array}$ & & $\begin{array}{c}0.867^{* *} \\
(0.377)\end{array}$ & & $\begin{array}{c}2.783 * * * \\
(0.995)\end{array}$ \\
\hline \multicolumn{7}{|c|}{ Short-run dynamics } \\
\hline e.c. & $\begin{array}{c}-0.119 * * * \\
(0.0354)\end{array}$ & $\begin{array}{l}-0.0809 \\
(0.0493)\end{array}$ & $\begin{array}{c}-0.166^{* * *} \\
(0.0308)\end{array}$ & $\begin{array}{l}-0.138^{* *} \\
(0.0568)\end{array}$ & $\begin{array}{c}-0.138^{* * *} \\
(0.0327)\end{array}$ & $\begin{array}{l}-0.0780^{*} \\
(0.0419)\end{array}$ \\
\hline$D . B S$ & $\begin{array}{l}-0.0741 \\
(0.0494)\end{array}$ & $\begin{array}{l}-0.0655 \\
(0.0481)\end{array}$ & $\begin{array}{c}-0.0593^{* *} \\
(0.0240)\end{array}$ & $\begin{array}{c}-0.0520 * * * \\
(0.0200)\end{array}$ & $\begin{array}{l}-0.0468 \\
(0.0599)\end{array}$ & $\begin{array}{l}-0.0408 \\
(0.0604)\end{array}$ \\
\hline D.NFA & & $\begin{array}{c}-0.0705 \\
(0.0571)\end{array}$ & & $\begin{array}{l}-0.0842 \\
(0.0679)\end{array}$ & & $\begin{array}{l}-0.0425 \\
(0.0581)\end{array}$ \\
\hline D.TOT & & $\begin{array}{c}0.371 \\
(0.257)\end{array}$ & & $\begin{array}{l}0.404 * \\
(0.234)\end{array}$ & & $\begin{array}{c}0.303 \\
(0.242)\end{array}$ \\
\hline Constant & $\begin{array}{c}0.568 * * * \\
(0.168)\end{array}$ & $\begin{array}{l}-0.132 * \\
(0.0786)\end{array}$ & $\begin{array}{c}0.774^{* * *} \\
(0.143)\end{array}$ & $\begin{array}{l}0.0988 * * \\
(0.0407)\end{array}$ & $\begin{array}{c}0.658 * * * \\
(0.155)\end{array}$ & $\begin{array}{l}-0.626^{*} \\
(0.334)\end{array}$ \\
\hline
\end{tabular}

Note: Standard errors are in parentheses. ${ }^{* * *} p<0.01,{ }^{* *} \mathrm{p}<0.05,{ }^{*} \mathrm{p}<0.1$. "e.c. " denotes the error-correction term. 


\section{B.2. Estimations (top 30 trade partners)}

Table B.2 - Equilibrium exchange rate model estimations (all countries)

\begin{tabular}{|c|c|c|c|c|c|c|c|c|c|}
\hline \multirow{3}{*}{$\begin{array}{l}\begin{array}{c}\text { Weighting } \\
\text { system }\end{array} \\
\text { Model }\end{array}$} & \multicolumn{6}{|c|}{ Fixed } & \multirow{2}{*}{\multicolumn{3}{|c|}{$\begin{array}{c}\text { Time-varying weights } \\
\text { (5-year averages) }\end{array}$}} \\
\hline & \multicolumn{3}{|c|}{$(1973-2016)$} & \multicolumn{3}{|c|}{$(2008-2012)$} & & & \\
\hline & (1) & (2) & (3) & (1) & (2) & (3) & (1) & (2) & (3) \\
\hline \multicolumn{10}{|c|}{ Long-run dynamics } \\
\hline$B S$ & $\begin{array}{c}0.336^{* * *} \\
(0.0226)\end{array}$ & $\begin{array}{c}0.534^{* * *} \\
(0.0291)\end{array}$ & $\begin{array}{c}0.130 * * * \\
(0.0217)\end{array}$ & $\begin{array}{c}0.282^{* * *} \\
(0.0208)\end{array}$ & $\begin{array}{c}0.274^{* * *} \\
(0.0236)\end{array}$ & $\begin{array}{c}0.0720^{* * *} \\
(0.0216)\end{array}$ & $\begin{array}{l}0.360^{* * *} \\
(0.0211)\end{array}$ & $\begin{array}{l}0.424^{* * *} \\
(0.0235)\end{array}$ & $\begin{array}{r}0.131^{* * *} \\
(0.0218)\end{array}$ \\
\hline NFA & & $\begin{array}{l}0.159 * * * \\
(0.0152)\end{array}$ & $\begin{array}{c}0.0427 * * * \\
(0.00613)\end{array}$ & & $\begin{array}{c}0.172 * * * \\
(0.0131)\end{array}$ & $\begin{array}{c}0.0422 * * * \\
(0.00613)\end{array}$ & & $\begin{array}{c}0.140 * * * \\
(0.0139)\end{array}$ & $\begin{array}{c}0.0394 * * * \\
(0.00561)\end{array}$ \\
\hline TOT & & & $\begin{array}{c}0.360 * * * \\
(0.0307)\end{array}$ & & & $\begin{array}{c}0.410 * * * \\
(0.0318)\end{array}$ & & & $\begin{array}{c}0.381 * * * \\
(0.0318)\end{array}$ \\
\hline \multicolumn{10}{|c|}{ Short-run dynamics } \\
\hline e.c. & $\begin{array}{c}-0.183^{* * *} \\
(0.0173)\end{array}$ & $\begin{array}{c}-0.145^{* * *} \\
(0.0146)\end{array}$ & $\begin{array}{c}-0.187^{* * *} \\
(0.0151)\end{array}$ & $\begin{array}{c}-0.183^{* * *} \\
(0.0166)\end{array}$ & $\begin{array}{c}-0.157^{* * *} \\
(0.0146)\end{array}$ & $\begin{array}{c}-0.188^{* * *} \\
(0.0164)\end{array}$ & $\begin{array}{c}-0.184^{* * *} \\
(0.0183)\end{array}$ & $\begin{array}{c}-0.150^{* * *} \\
(0.0148)\end{array}$ & $\begin{array}{c}-0.191^{* * *} \\
(0.0166)\end{array}$ \\
\hline$D . B S$ & $\begin{array}{l}0.208^{*} \\
(0.122)\end{array}$ & $\begin{array}{c}0.134 \\
(0.123)\end{array}$ & $\begin{array}{c}0.165 \\
(0.153)\end{array}$ & $\begin{array}{c}0.218^{*} \\
(0.115)\end{array}$ & $\begin{array}{c}0.164 \\
(0.121)\end{array}$ & $\begin{array}{c}0.178 \\
(0.141)\end{array}$ & $\begin{array}{c}0.233^{* *} \\
(0.104)\end{array}$ & $\begin{array}{c}0.192 \\
(0.120)\end{array}$ & $\begin{array}{c}0.202 \\
(0.125)\end{array}$ \\
\hline D.NFA & & $\begin{array}{c}0.0165 \\
(0.0402)\end{array}$ & $\begin{array}{c}0.0556 * * * \\
(0.0212)\end{array}$ & & $\begin{array}{r}-0.00115 \\
(0.0510)\end{array}$ & $\begin{array}{c}0.0551^{* * *} \\
(0.0207)\end{array}$ & & $\begin{array}{c}0.0101 \\
(0.0417)\end{array}$ & $\begin{array}{c}0.0572^{* *} \\
(0.0242)\end{array}$ \\
\hline D.TOT & & & $\begin{array}{l}0.0810 \\
(0.112)\end{array}$ & & & $\begin{array}{l}0.0904 \\
(0.118)\end{array}$ & & & $\begin{array}{c}0.112 \\
(0.181)\end{array}$ \\
\hline Constant & $\begin{array}{c}0.913^{* * *} \\
(0.0839)\end{array}$ & $\begin{array}{l}0.778^{* * *} \\
(0.0751)\end{array}$ & $\begin{array}{c}0.580 * * * \\
(0.0470)\end{array}$ & $\begin{array}{l}0.905^{* * *} \\
(0.0794)\end{array}$ & $\begin{array}{l}0.796 * * * \\
(0.0713)\end{array}$ & $\begin{array}{c}0.530 * * * \\
(0.0460)\end{array}$ & $\begin{array}{l}0.922^{* * *} \\
(0.0888)\end{array}$ & $\begin{array}{l}0.786 * * * \\
(0.0747)\end{array}$ & $\begin{array}{c}0.577^{* * *} \\
(0.0499)\end{array}$ \\
\hline
\end{tabular}

Note: Standard errors are in parentheses. ${ }^{* * *} p<0.01,{ }^{* *} p<0.05,{ }^{*} p<0.1$. "e.c." denotes the error-correction term. 


\section{B.2.1. Development levels}

Table B.2.1.1 - Equilibrium exchange rate model estimations (advanced economies)

\begin{tabular}{|c|c|c|c|c|c|c|c|c|c|}
\hline \multirow{2}{*}{$\begin{array}{l}\begin{array}{c}\text { Weighting } \\
\text { system }\end{array} \\
\text { Model }\end{array}$} & \multicolumn{6}{|c|}{ Fixed } & \multirow{2}{*}{\multicolumn{3}{|c|}{$\begin{array}{c}\text { Time-varying weights } \\
\text { (5-year averages) }\end{array}$}} \\
\hline & (1) & \multicolumn{2}{|l|}{$(1973-2016)$} & (1) & $(2008-2012)$ & (3) & & & (3) \\
\hline \multicolumn{10}{|c|}{ Long-run dynamics } \\
\hline$B S$ & $\begin{array}{c}-0.493 * * * \\
(0.0451)\end{array}$ & $\begin{array}{c}0.0441 \\
(0.0349)\end{array}$ & $\begin{array}{c}0.0349 \\
(0.0352)\end{array}$ & $\begin{array}{l}0.0805^{* *} \\
(0.0387)\end{array}$ & $\begin{array}{c}0.0249 \\
(0.0324)\end{array}$ & $\begin{array}{c}0.0168 \\
(0.0272)\end{array}$ & $\begin{array}{l}0.213 * * * \\
(0.0528)\end{array}$ & $\begin{array}{c}0.197 * * * \\
(0.0476)\end{array}$ & $\begin{array}{l}0.133^{* * *} \\
(0.0506)\end{array}$ \\
\hline$N F A$ & & $\begin{array}{l}0.0386 * * * \\
(0.00765)\end{array}$ & $\begin{array}{l}0.00700 \\
(0.0103)\end{array}$ & & $\begin{array}{c}0.0338 * * * \\
(0.0118)\end{array}$ & $\begin{array}{l}0.0233^{* *} \\
(0.0116)\end{array}$ & & $\begin{array}{c}-0.0560 * * * \\
(0.0167)\end{array}$ & $\begin{array}{c}0.0164^{*} \\
(0.00990)\end{array}$ \\
\hline TOT & & & $\begin{array}{l}1.052 * * * \\
(0.0781)\end{array}$ & & & $\begin{array}{l}0.702 * * * \\
(0.0913)\end{array}$ & & & $\begin{array}{l}0.969 * * * \\
(0.0732)\end{array}$ \\
\hline \multicolumn{10}{|c|}{ Short-run dynamics } \\
\hline e.c. & $\begin{array}{c}-0.107 * * * \\
(0.0308)\end{array}$ & $\begin{array}{c}-0.175^{* * *} \\
(0.0298)\end{array}$ & $\begin{array}{c}-0.202 * * * \\
(0.0343)\end{array}$ & $\begin{array}{c}-0.152 * * * \\
(0.0218)\end{array}$ & $\begin{array}{c}-0.165^{* * *} \\
(0.0260)\end{array}$ & $\begin{array}{c}-0.192 * * * \\
(0.0292)\end{array}$ & $\begin{array}{c}-0.189 * * * \\
(0.0372)\end{array}$ & $\begin{array}{c}-0.167^{* * *} \\
(0.0270)\end{array}$ & $\begin{array}{r}-0.198 * * * \\
(0.0350)\end{array}$ \\
\hline$D . B S$ & $\begin{array}{c}0.0404 \\
(0.0744)\end{array}$ & $\begin{array}{l}-0.0316 \\
(0.0609)\end{array}$ & $\begin{array}{c}-0.0929 * * \\
(0.0473)\end{array}$ & $\begin{array}{c}0.0229 \\
(0.0910)\end{array}$ & $\begin{array}{l}-0.0539 \\
(0.0501)\end{array}$ & $\begin{array}{c}-0.0877^{* *} \\
(0.0402)\end{array}$ & $\begin{array}{c}-1.29 \mathrm{e}-05 \\
(0.0407)\end{array}$ & $\begin{array}{c}0.0197 \\
(0.0389)\end{array}$ & $\begin{array}{l}-0.0369 \\
(0.0359)\end{array}$ \\
\hline$D . N F A$ & & $\begin{array}{l}-0.0322 \\
(0.0496)\end{array}$ & $\begin{array}{l}-0.0694 \\
(0.0427)\end{array}$ & & $\begin{array}{l}-0.0203 \\
(0.0464)\end{array}$ & $\begin{array}{l}-0.0698 \\
(0.0439)\end{array}$ & & & $\begin{array}{l}-0.0666 \\
(0.0456)\end{array}$ \\
\hline D.TOT & & & $\begin{array}{c}0.287^{* * *} \\
(0.0891)\end{array}$ & & & $\begin{array}{l}0.354 * * * \\
(0.0849)\end{array}$ & & & $\begin{array}{l}0.275^{* * *} \\
(0.0866)\end{array}$ \\
\hline Constant & $\begin{array}{c}0.498 * * * \\
(0.137)\end{array}$ & $\begin{array}{c}0.811^{* * *} \\
(0.141)\end{array}$ & $\begin{array}{c}-0.0458 * * * \\
(0.00866)\end{array}$ & $\begin{array}{c}0.695^{* * * *} \\
(0.100)\end{array}$ & $\begin{array}{c}0.761^{* * *} \\
(0.120)\end{array}$ & $\begin{array}{c}0.266 * * * \\
(0.0401)\end{array}$ & $\begin{array}{c}0.858^{* * * *} \\
(0.171)\end{array}$ & $\begin{array}{c}0.758^{* * *} * \\
(0.123)\end{array}$ & $\begin{array}{c}0.0276 * * * \\
(0.00652)\end{array}$ \\
\hline
\end{tabular}

Note: Standard errors are in parentheses. ${ }^{* * *} p<0.01, * * p<0.05, * p<0.1$. "e.c." denotes the error-correction term. 
Table B.2.1.2 - Equilibrium exchange rate model estimations (emerging economies)

\begin{tabular}{|c|c|c|c|c|c|c|c|c|c|}
\hline \multirow{2}{*}{$\begin{array}{ll}\begin{array}{c}\text { Weighting } \\
\text { system }\end{array} \\
\text { Model } \\
\end{array}$} & \multicolumn{6}{|c|}{ Fixed } & \multicolumn{3}{|c|}{$\begin{array}{c}\text { Time-varying weights } \\
\text { (5-year averages) }\end{array}$} \\
\hline & (1) & $(2)$ & (3) & (1) & $(2)$ & (3) & (1) & (2) & (3) \\
\hline \multicolumn{10}{|c|}{ Long-run dynamics } \\
\hline$B S$ & $\begin{array}{l}0.397 * * * \\
(0.0388)\end{array}$ & $\begin{array}{l}0.769 * * * \\
(0.0486)\end{array}$ & $\begin{array}{l}-0.0247 \\
(0.0347)\end{array}$ & $\begin{array}{l}0.245 * * * \\
(0.0394)\end{array}$ & $\begin{array}{l}0.678 * * * \\
(0.0554)\end{array}$ & $\begin{array}{l}-0.0733^{*} \\
(0.0395)\end{array}$ & $\begin{array}{l}0.339 * * * \\
(0.0342)\end{array}$ & $\begin{array}{l}0.513 * * * \\
(0.0385)\end{array}$ & $\begin{array}{r}-0.00846 \\
(0.0234)\end{array}$ \\
\hline$N F A$ & & $\begin{array}{l}0.187 * * * \\
(0.0396)\end{array}$ & $\begin{array}{l}-0.0255 \\
(0.0263)\end{array}$ & & $\begin{array}{l}0.155^{* * *} \\
(0.0349)\end{array}$ & $\begin{array}{l}0.00188 \\
(0.0270)\end{array}$ & & $\begin{array}{l}0.211 * * * \\
(0.0370)\end{array}$ & $\begin{array}{l}-0.0228 \\
(0.0263)\end{array}$ \\
\hline TOT & & & $\begin{array}{c}0.234^{* * *} \\
(0.0300)\end{array}$ & & & $\begin{array}{c}0.322^{* * *} \\
(0.0375)\end{array}$ & & & $\begin{array}{c}0.267^{* * *} \\
(0.0248)\end{array}$ \\
\hline \multicolumn{10}{|c|}{ Short-run dynamics } \\
\hline e.c. & $\begin{array}{c}-0.208^{* * *} * \\
(0.0397)\end{array}$ & $\begin{array}{c}-0.188 * * * \\
(0.0374)\end{array}$ & $\begin{array}{c}-0.197^{* * *} \\
(0.0343)\end{array}$ & $\begin{array}{c}-0.220 * * * \\
(0.0381)\end{array}$ & $\begin{array}{c}-0.195 * * * \\
(0.0374)\end{array}$ & $\begin{array}{c}-0.205^{* * *} \\
(0.0361)\end{array}$ & $\begin{array}{c}-0.207^{* * *} \\
(0.0410)\end{array}$ & $\begin{array}{c}-0.188 * * * \\
(0.0377)\end{array}$ & $\begin{array}{c}-0.211^{* * *} \\
(0.0387)\end{array}$ \\
\hline$D . B S$ & $\begin{array}{c}0.514 * * \\
(0.256)\end{array}$ & $\begin{array}{c}0.329 \\
(0.206)\end{array}$ & $\begin{array}{c}0.250 * * * \\
(0.0780)\end{array}$ & $\begin{array}{l}0.467^{*} \\
(0.241)\end{array}$ & $\begin{array}{c}0.344 \\
(0.241)\end{array}$ & $\begin{array}{c}0.187^{* *} \\
(0.0790)\end{array}$ & $\begin{array}{c}0.477^{* *} \\
(0.192)\end{array}$ & $\begin{array}{c}0.337^{*} \\
(0.174)\end{array}$ & $\begin{array}{c}0.263^{* * *} \\
(0.0606)\end{array}$ \\
\hline$D . N F A$ & & $\begin{array}{r}-0.0186 \\
(0.110)\end{array}$ & $\begin{array}{l}0.134 * * * \\
(0.0397)\end{array}$ & & $\begin{array}{r}-0.0530 \\
(0.157)\end{array}$ & $\begin{array}{l}0.133 * * * \\
(0.0386)\end{array}$ & & $\begin{array}{l}-0.0375 \\
(0.111)\end{array}$ & $\begin{array}{l}0.115^{* * *} \\
(0.0410)\end{array}$ \\
\hline D.TOT & & & $\begin{array}{l}-0.0757 \\
(0.0585)\end{array}$ & & & $\begin{array}{l}-0.109 * \\
(0.0660)\end{array}$ & & & $\begin{array}{l}-0.148 * \\
(0.0798)\end{array}$ \\
\hline Constant & $\begin{array}{c}1.009 * * * \\
(0.190)\end{array}$ & $\begin{array}{c}0.996 * * * \\
(0.192)\end{array}$ & $\begin{array}{c}0.685^{* * * *} \\
(0.121)\end{array}$ & $\begin{array}{c}1.041^{* * *} \\
(0.178)\end{array}$ & $\begin{array}{c}1.005^{* * *} \\
(0.188)\end{array}$ & $\begin{array}{c}0.627^{* * *} \\
(0.112)\end{array}$ & $\begin{array}{c}0.992 * * * \\
(0.195)\end{array}$ & $\begin{array}{c}0.961^{* * *} \\
(0.188)\end{array}$ & $\begin{array}{c}0.698 * * * \\
(0.131)\end{array}$ \\
\hline
\end{tabular}


Table B.2.1.3 - Equilibrium exchange rate model estimations (developing countries)

\begin{tabular}{|c|c|c|c|c|c|c|c|c|c|}
\hline $\begin{array}{c}\begin{array}{c}\text { Weighting } \\
\text { system }\end{array} \\
\text { Model } \\
\end{array}$ & (1) & $(2)$ & (3) & (1) & (2) & (3) & (1) & (2) & $(3)$ \\
\hline \multicolumn{10}{|c|}{ Long-run dynamics } \\
\hline$B S$ & $\begin{array}{l}0.388 * * * \\
(0.0305)\end{array}$ & $\begin{array}{l}0.239 * * * \\
(0.0318)\end{array}$ & $\begin{array}{l}0.453 * * * \\
(0.0378)\end{array}$ & $\begin{array}{l}0.370^{* * *} \\
(0.0289)\end{array}$ & $\begin{array}{c}0.140 * * * \\
(0.0267)\end{array}$ & $\begin{array}{c}0.246 * * * \\
(0.0334)\end{array}$ & $\begin{array}{c}0.399 * * * \\
(0.0290)\end{array}$ & $\begin{array}{l}0.106 * * * \\
(0.0134)\end{array}$ & $\begin{array}{c}0.167^{* * *} \\
(0.0337)\end{array}$ \\
\hline NFA & & $\begin{array}{c}0.227 * * * \\
(0.0197)\end{array}$ & $\begin{array}{c}0.102 * * * \\
(0.0110)\end{array}$ & & $\begin{array}{c}0.269 * * * \\
(0.0209)\end{array}$ & $\begin{array}{c}0.0456 * * * \\
(0.00818)\end{array}$ & & $\begin{array}{c}0.200 * * * \\
(0.0180)\end{array}$ & $\begin{array}{c}0.0352 * * * \\
(0.00817)\end{array}$ \\
\hline TOT & & & $\begin{array}{l}0.315^{* * *} * \\
(0.0344)\end{array}$ & & & $\begin{array}{c}0.265^{* * *} * \\
(0.0362)\end{array}$ & & & $\begin{array}{c}0.285^{* * *} \\
(0.0386)\end{array}$ \\
\hline \multicolumn{10}{|c|}{ Short-run dynamics } \\
\hline e.c. & $\begin{array}{c}-0.177^{* * *} \\
(0.0217)\end{array}$ & $\begin{array}{c}-0.138^{* * *} \\
(0.0152)\end{array}$ & $\begin{array}{c}-0.150 * * * \\
(0.0173)\end{array}$ & $\begin{array}{c}-0.178^{* * *} \\
(0.0212)\end{array}$ & $\begin{array}{c}-0.145^{* * *} \\
(0.0155)\end{array}$ & $\begin{array}{c}-0.191 * * * \\
(0.0230)\end{array}$ & $\begin{array}{c}-0.172 * * * \\
(0.0225)\end{array}$ & $\begin{array}{c}-0.147^{* * *} \\
(0.0166)\end{array}$ & $\begin{array}{c}-0.190^{* * * *} \\
(0.0227)\end{array}$ \\
\hline$D . B S$ & $\begin{array}{c}0.108 \\
(0.174)\end{array}$ & $\begin{array}{l}0.0825 \\
(0.197)\end{array}$ & $\begin{array}{c}0.181 \\
(0.280)\end{array}$ & $\begin{array}{c}0.142 \\
(0.163)\end{array}$ & $\begin{array}{c}0.127 \\
(0.181)\end{array}$ & $\begin{array}{c}0.245 \\
(0.259)\end{array}$ & $\begin{array}{c}0.174 \\
(0.159)\end{array}$ & $\begin{array}{c}0.179 \\
(0.200)\end{array}$ & $\begin{array}{c}0.246 \\
(0.230)\end{array}$ \\
\hline D.NFA & & $\begin{array}{c}0.0303 \\
(0.0426)\end{array}$ & $\begin{array}{c}0.0625 * * \\
(0.0285)\end{array}$ & & $\begin{array}{c}0.0191 \\
(0.0424)\end{array}$ & $\begin{array}{c}0.0551^{* *} \\
(0.0271)\end{array}$ & & $\begin{array}{c}0.0374 \\
(0.0461)\end{array}$ & $\begin{array}{l}0.0677^{*} \\
(0.0352)\end{array}$ \\
\hline D.TOT & & & $\begin{array}{c}0.108 \\
(0.205)\end{array}$ & & & $\begin{array}{c}0.133 \\
(0.215)\end{array}$ & & & $\begin{array}{c}0.204 \\
(0.333)\end{array}$ \\
\hline Constant & $\begin{array}{c}0.941^{* * *} \\
(0.109)\end{array}$ & $\begin{array}{c}0.737 * * * \\
(0.0793)\end{array}$ & $\begin{array}{c}0.589 * * * \\
(0.0667)\end{array}$ & $\begin{array}{c}0.941^{* * *} \\
(0.106)\end{array}$ & $\begin{array}{c}0.753^{* * *} \\
(0.0780)\end{array}$ & $\begin{array}{c}0.720 * * * \\
(0.0850)\end{array}$ & $\begin{array}{c}0.918^{* * * *} \\
(0.114)\end{array}$ & $\begin{array}{c}0.751^{* * *} \\
(0.0831)\end{array}$ & $\begin{array}{c}0.682^{* * *} \\
(0.0790)\end{array}$ \\
\hline
\end{tabular}

Note: Standard errors are in parentheses. ${ }^{* * *} p<0.01,{ }^{*} p<0.05,{ }^{*} p<0.1$. "e.c." denotes the error-correction term. 
B.2.2. Monetary unions

Table B.2.2.1 - Equilibrium exchange rate model estimations (CAEMC)

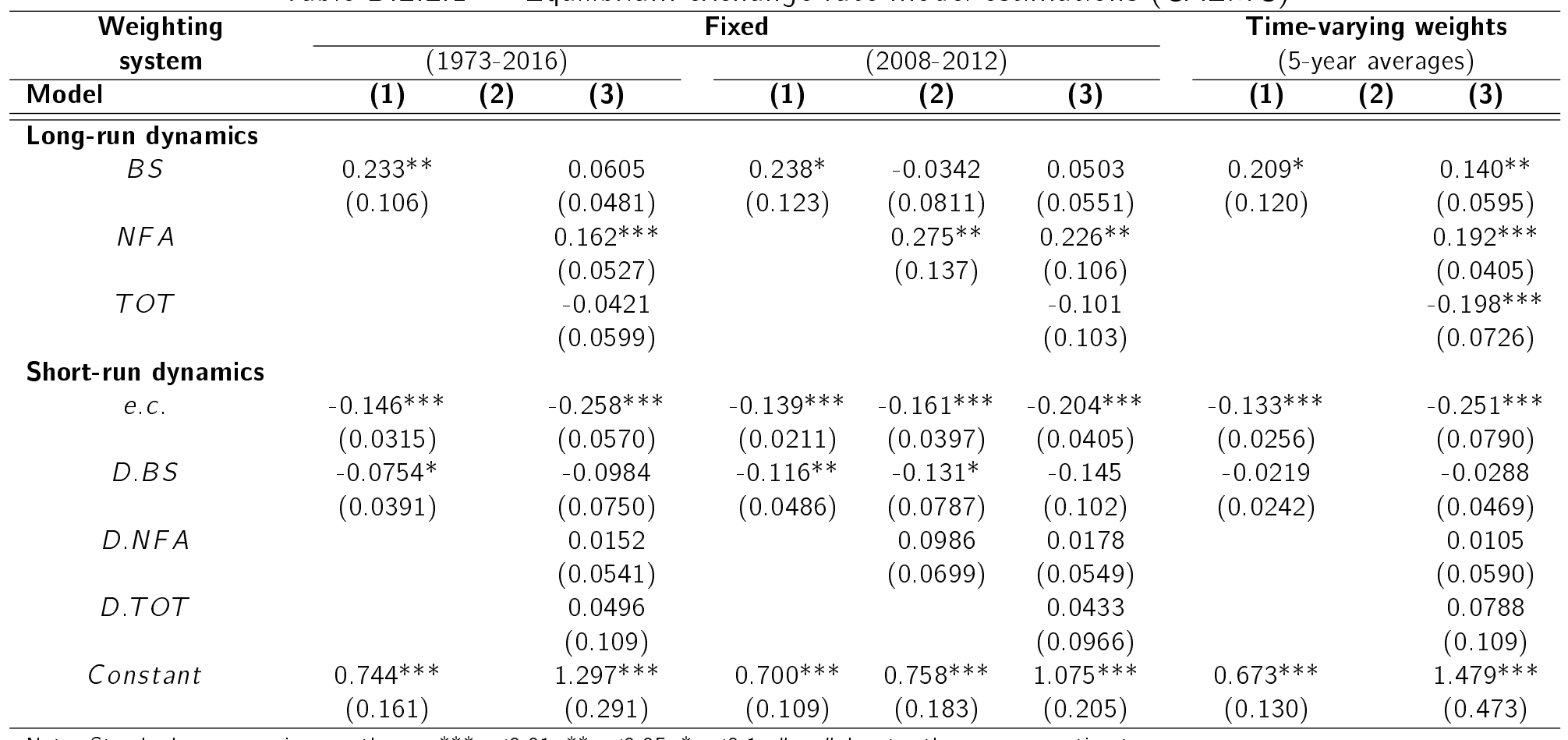

Note: Standard errors are in parentheses. ${ }^{* * *} p<0.01,{ }^{* *} p<0.05, * p<0.1$. "e.c." denotes the error-correction term. 
Table B.2.2.2 - Equilibrium exchange rate model estimations (CFA)

\begin{tabular}{|c|c|c|c|c|c|c|c|c|c|}
\hline \multirow{3}{*}{$\begin{array}{c}\begin{array}{c}\text { Weighting } \\
\text { system }\end{array} \\
\text { Model }\end{array}$} & \multicolumn{6}{|c|}{ Fixed } & \multirow{2}{*}{\multicolumn{3}{|c|}{$\begin{array}{l}\text { Time-varying weights } \\
\text { (5-year averages) }\end{array}$}} \\
\hline & \multicolumn{3}{|c|}{$(1973-2016)$} & \multicolumn{3}{|c|}{$(2008-2012)$} & & & \\
\hline & (1) & $(2)$ & (3) & (1) & $(2)$ & (3) & (1) & $(2)$ & (3) \\
\hline \multicolumn{10}{|c|}{ Long-run dynamics } \\
\hline$B S$ & $\begin{array}{l}0.193^{* *} \\
(0.0775)\end{array}$ & $\begin{array}{c}-5.985^{* * *} \\
(1.297)\end{array}$ & $\begin{array}{c}0.0606 \\
(0.0457)\end{array}$ & $\begin{array}{c}0.202 * * * \\
(0.0690)\end{array}$ & $\begin{array}{l}0.164 * * \\
(0.0663)\end{array}$ & $\begin{array}{l}0.259 * * * \\
(0.0665)\end{array}$ & $\begin{array}{l}0.185^{* *} \\
(0.0876)\end{array}$ & $\begin{array}{l}-2.258^{*} \\
(1.194)\end{array}$ & $\begin{array}{c}0.0679 \\
(0.0448)\end{array}$ \\
\hline$N F A$ & & $\begin{array}{c}-2.834 * * * \\
(0.823)\end{array}$ & $\begin{array}{l}0.145 * * * \\
(0.0434)\end{array}$ & & $\begin{array}{l}0.201^{* *} \\
(0.0818)\end{array}$ & $\begin{array}{l}0.261 * * * \\
(0.0811)\end{array}$ & & $\begin{array}{l}-0.305 \\
(0.375)\end{array}$ & $\begin{array}{l}0.210 * * * \\
(0.0418)\end{array}$ \\
\hline TOT & & & $\begin{array}{r}-0.00386 \\
(0.0582)\end{array}$ & & & $\begin{array}{l}0.168^{* *} \\
(0.0777)\end{array}$ & & & $\begin{array}{c}-0.119^{* *} \\
(0.0569)\end{array}$ \\
\hline \multicolumn{10}{|c|}{ Short-run dynamics } \\
\hline e.c. & $\begin{array}{c}-0.158^{* * *} \\
(0.0243)\end{array}$ & $\begin{array}{l}-0.0196 \\
(0.0219)\end{array}$ & $\begin{array}{c}-0.216^{* * *} \\
(0.0302)\end{array}$ & $\begin{array}{c}-0.170^{* * *} \\
(0.0218)\end{array}$ & $\begin{array}{c}-0.167^{* * *} \\
(0.0217)\end{array}$ & $\begin{array}{c}-0.171^{* * *} \\
(0.0397)\end{array}$ & $\begin{array}{c}-0.160^{* * *} \\
(0.0238)\end{array}$ & $\begin{array}{l}-0.0126 \\
(0.0131)\end{array}$ & $\begin{array}{r}-0.220 * * * \\
(0.0357)\end{array}$ \\
\hline$D . B S$ & $\begin{array}{l}-0.349 \\
(0.265)\end{array}$ & $\begin{array}{l}-0.249 \\
(0.176)\end{array}$ & $\begin{array}{l}-0.396 \\
(0.331)\end{array}$ & $\begin{array}{c}-0.226 * * \\
(0.0933)\end{array}$ & $\begin{array}{c}-0.247^{* * *} * \\
(0.0934)\end{array}$ & $\begin{array}{c}-0.293 * * \\
(0.140)\end{array}$ & $\begin{array}{l}-0.0827 \\
(0.0724)\end{array}$ & $\begin{array}{l}-0.0215 \\
(0.0550)\end{array}$ & $\begin{array}{l}-0.111 \\
(0.132)\end{array}$ \\
\hline D.NFA & & $\begin{array}{l}0.271^{* * *} \\
(0.0795)\end{array}$ & $\begin{array}{l}0.204 * * \\
(0.0922)\end{array}$ & & $\begin{array}{l}0.208 * * * \\
(0.0630)\end{array}$ & $\begin{array}{l}0.198^{* *} \\
(0.0815)\end{array}$ & & $\begin{array}{l}0.234 * * * \\
(0.0607)\end{array}$ & $\begin{array}{c}0.141^{* *} \\
(0.0608)\end{array}$ \\
\hline D.TOT & & & $\begin{array}{l}-0.0253 \\
(0.110)\end{array}$ & & & $\begin{array}{l}-0.0618 \\
(0.0717)\end{array}$ & & & $\begin{array}{l}-0.0572 \\
(0.175)\end{array}$ \\
\hline Constant & $\begin{array}{c}0.778^{* * *} \\
(0.122)\end{array}$ & $\begin{array}{l}-0.182 \\
(0.192)\end{array}$ & $\begin{array}{c}1.043 * * * \\
(0.148)\end{array}$ & $\begin{array}{c}0.841^{* * *} \\
(0.111)\end{array}$ & $\begin{array}{c}0.835 * * * \\
(0.111)\end{array}$ & $\begin{array}{c}0.767 * * * \\
(0.181)\end{array}$ & $\begin{array}{c}0.786^{* * *} \\
(0.119)\end{array}$ & $\begin{array}{c}-0.0195 * * * \\
(0.00745)\end{array}$ & $\begin{array}{c}1.183^{* * *} \\
(0.196)\end{array}$ \\
\hline
\end{tabular}

Note: Standard errors are in parentheses. $* * * p<0.01,{ }^{*} p<0.05, * p<0.1$. "e.c." denotes the error-correction term. 
Table B.2.2.3 - Equilibrium exchange rate model estimations (CMA)

\begin{tabular}{|c|c|c|c|c|c|c|c|c|c|}
\hline \multirow{3}{*}{$\begin{array}{l}\begin{array}{c}\text { Weighting } \\
\text { system }\end{array} \\
\text { Model }\end{array}$} & \multicolumn{6}{|c|}{ Fixed } & \multirow{2}{*}{\multicolumn{3}{|c|}{$\begin{array}{l}\text { Time-varying weights } \\
\text { (5-year averages) }\end{array}$}} \\
\hline & \multicolumn{3}{|c|}{$(1973-2016)$} & \multicolumn{3}{|c|}{$(2008-2012)$} & & & \\
\hline & (1) & (2) & (3) & (1) & (2) & (3) & (1) & (2) & (3) \\
\hline \multicolumn{10}{|c|}{ Long-run dynamics } \\
\hline$B S$ & $\begin{array}{l}-1.748^{*} \\
(0.907)\end{array}$ & $\begin{array}{c}0.675 * * * \\
(0.158)\end{array}$ & $\begin{array}{c}0.806 * * * \\
(0.198)\end{array}$ & $\begin{array}{c}-1.508^{* *} \\
(0.719)\end{array}$ & $\begin{array}{l}-0.271 \\
(0.594)\end{array}$ & $\begin{array}{l}-0.632 \\
(0.461)\end{array}$ & $\begin{array}{c}-1.250^{* *} \\
(0.534)\end{array}$ & & $\begin{array}{l}-0.158 \\
(0.281)\end{array}$ \\
\hline$N F A$ & & $\begin{array}{l}0.174^{* * *} \\
(0.0665)\end{array}$ & $\begin{array}{l}0.230^{* *} \\
(0.0918)\end{array}$ & & $\begin{array}{c}0.0526 \\
(0.0995)\end{array}$ & $\begin{array}{c}0.104 \\
(0.0779)\end{array}$ & & & $\begin{array}{l}0.186 * * * \\
(0.0716)\end{array}$ \\
\hline TOT & & & $\begin{array}{c}0.136 \\
(0.564)\end{array}$ & & & $\begin{array}{c}0.719 * * * \\
(0.269)\end{array}$ & & & $\begin{array}{l}0.555^{*} \\
(0.324)\end{array}$ \\
\hline \multicolumn{10}{|c|}{ Short-run dynamics } \\
\hline e.c. & $\begin{array}{c}-0.0443 \\
(0.0331)\end{array}$ & $\begin{array}{l}-0.235^{*} \\
(0.135)\end{array}$ & $\begin{array}{l}-0.272^{*} \\
(0.154)\end{array}$ & $\begin{array}{c}-0.0530 \\
(0.0369)\end{array}$ & $\begin{array}{l}-0.182 \\
(0.121)\end{array}$ & $\begin{array}{l}-0.252^{*} \\
(0.150)\end{array}$ & $\begin{array}{l}-0.0600 \\
(0.0415)\end{array}$ & & $\begin{array}{l}-0.262^{*} \\
(0.155)\end{array}$ \\
\hline D.BS & $\begin{array}{l}0.244^{* *} \\
(0.122)\end{array}$ & $\begin{array}{l}-0.0612 \\
(0.227)\end{array}$ & $\begin{array}{l}-0.0172 \\
(0.205)\end{array}$ & $\begin{array}{l}0.289 * * \\
(0.125)\end{array}$ & $\begin{array}{c}0.184 \\
(0.152)\end{array}$ & $\begin{array}{l}0.372^{*} \\
(0.208)\end{array}$ & $\begin{array}{l}0.243^{*} \\
(0.130)\end{array}$ & & $\begin{array}{c}0.263 \\
(0.165)\end{array}$ \\
\hline D.NFA & & $\begin{array}{c}0.116^{*} \\
(0.0600)\end{array}$ & $\begin{array}{c}0.0609 \\
(0.0873)\end{array}$ & & $\begin{array}{l}0.109 * * \\
(0.0543)\end{array}$ & $\begin{array}{c}0.102^{*} \\
(0.0617)\end{array}$ & & & $\begin{array}{c}0.143^{*} \\
(0.0854)\end{array}$ \\
\hline D.TOT & & & $\begin{array}{l}-0.409 \\
(0.298)\end{array}$ & & & $\begin{array}{c}-0.110 \\
(0.0834)\end{array}$ & & & $\begin{array}{l}-0.591 \\
(0.479)\end{array}$ \\
\hline Constant & $\begin{array}{c}0.0761 \\
(0.0889)\end{array}$ & $\begin{array}{l}1.282 \\
(0.797)\end{array}$ & $\begin{array}{l}1.368 \\
(0.853)\end{array}$ & $\begin{array}{c}0.131 \\
(0.117)\end{array}$ & $\begin{array}{c}0.748 \\
(0.514)\end{array}$ & $\begin{array}{c}0.109 \\
(0.0922)\end{array}$ & $\begin{array}{c}0.152 \\
(0.129)\end{array}$ & & $\begin{array}{c}0.471 \\
(0.296)\end{array}$ \\
\hline
\end{tabular}


Table B.2.2.4 - Equilibrium exchange rate model estimations (ECMU)

\begin{tabular}{|c|c|c|c|c|c|c|c|c|c|}
\hline \multirow{3}{*}{$\begin{array}{c}\text { Weighting } \\
\text { system }\end{array}$} & \multicolumn{6}{|c|}{ Fixed } & \multirow{2}{*}{\multicolumn{3}{|c|}{$\begin{array}{l}\text { Time-varying weights } \\
\text { (5-year averages) }\end{array}$}} \\
\hline & \multicolumn{3}{|c|}{$(1973-2016)$} & \multicolumn{3}{|c|}{$(2008-2012)$} & & & \\
\hline & (1) & (2) & (3) & (1) & (2) & (3) & (1) & (2) & (3) \\
\hline \multicolumn{10}{|c|}{ Long-run dynamics } \\
\hline$B S$ & $\begin{array}{c}0.0303 \\
(0.0596)\end{array}$ & $\begin{array}{l}-0.00387 \\
(0.0800)\end{array}$ & $\begin{array}{l}0.354^{* *} \\
(0.168)\end{array}$ & & $\begin{array}{l}-0.113 \\
(0.159)\end{array}$ & & $\begin{array}{c}-0.209 * * * \\
(0.0735)\end{array}$ & $\begin{array}{l}-0.0328 \\
(0.0951)\end{array}$ & $\begin{array}{l}-1.547 \\
(3.741)\end{array}$ \\
\hline$N F A$ & & $\begin{array}{l}0.229 * * * \\
(0.0337)\end{array}$ & $\begin{array}{l}-0.0237 \\
(0.0331)\end{array}$ & & $\begin{array}{c}0.446 * * * \\
(0.104)\end{array}$ & & & $\begin{array}{l}0.192 * * * \\
(0.0329)\end{array}$ & $\begin{array}{l}-1.176 \\
(3.121)\end{array}$ \\
\hline TOT & & & $\begin{array}{c}0.288 \\
(0.221)\end{array}$ & & & & & & $\begin{array}{c}9.200 \\
(21.56)\end{array}$ \\
\hline \multicolumn{10}{|c|}{ Short-run dynamics } \\
\hline e.c. & $\begin{array}{c}-0.159 * * * \\
(0.0583)\end{array}$ & $\begin{array}{c}-0.0970^{*} \\
(0.0525)\end{array}$ & $\begin{array}{l}-0.179^{*} \\
(0.103)\end{array}$ & & $\begin{array}{c}-0.0531^{*} \\
(0.0302)\end{array}$ & & $\begin{array}{c}-0.173^{* * *} \\
(0.0574)\end{array}$ & $\begin{array}{c}-0.100 * * \\
(0.0485)\end{array}$ & $\begin{array}{c}0.00322 \\
(0.00678)\end{array}$ \\
\hline$D . B S$ & $\begin{array}{c}-0.0488 * * * \\
(0.0160)\end{array}$ & $\begin{array}{c}-0.0459^{* * *} \\
(0.0145)\end{array}$ & $\begin{array}{c}-0.0439 * * * \\
(0.0141)\end{array}$ & & $\begin{array}{c}-0.0562 * * * \\
(0.0195)\end{array}$ & & $\begin{array}{l}-0.00994 \\
(0.00899)\end{array}$ & $\begin{array}{c}-0.0245 * * * \\
(0.00855)\end{array}$ & $\begin{array}{r}-0.0175^{* *} \\
(0.00708)\end{array}$ \\
\hline D.NFA & & $\begin{array}{c}-0.0351^{* *} \\
(0.0157)\end{array}$ & $\begin{array}{l}-0.0286 \\
(0.0218)\end{array}$ & & $\begin{array}{l}-0.0200^{*} \\
(0.0113)\end{array}$ & & & $\begin{array}{c}-0.0324^{*} \\
(0.0183)\end{array}$ & $\begin{array}{l}-0.0359 \\
(0.0342)\end{array}$ \\
\hline D.TOT & & & $\begin{array}{l}-0.0401 \\
(0.0690)\end{array}$ & & & & & & $\begin{array}{c}0.0269 \\
(0.0631)\end{array}$ \\
\hline Constant & $\begin{array}{c}0.737 * * * \\
(0.268)\end{array}$ & $\begin{array}{l}0.476^{*} \\
(0.257)\end{array}$ & $\begin{array}{l}0.626^{*} \\
(0.359)\end{array}$ & & $\begin{array}{l}0.265^{*} \\
(0.150)\end{array}$ & & $\begin{array}{c}0.757^{* * * *} \\
(0.249)\end{array}$ & $\begin{array}{l}0.484^{* *} \\
(0.234)\end{array}$ & $\begin{array}{c}0.128 \\
(0.278)\end{array}$ \\
\hline
\end{tabular}

Note: Standard errors are in parentheses. ${ }^{* * *} \mathrm{p}<0.01,{ }^{*} \mathrm{p}<0.05, * \mathrm{p}<0.1$. "e.c." denotes the error-correction term. 
Table B.2.2.5 - Equilibrium exchange rate model estimations (EMU)

\begin{tabular}{|c|c|c|c|c|c|c|c|c|c|}
\hline \multirow{2}{*}{$\begin{array}{c}\text { Weighting } \\
\text { system }\end{array}$} & \multicolumn{6}{|c|}{ Fixed } & \multicolumn{3}{|c|}{$\begin{array}{l}\text { Time-varying weights } \\
\text { (5-year averages) }\end{array}$} \\
\hline & (1) & $(2)$ & (3) & (1) & $(2)$ & (3) & (1) & $(2)$ & (3) \\
\hline \multicolumn{10}{|l|}{ Long-run dynamics } \\
\hline$B S$ & $\begin{array}{l}0.853 * * * \\
(0.0694)\end{array}$ & $\begin{array}{c}0.0874 * * \\
(0.0422)\end{array}$ & $\begin{array}{c}0.0515 \\
(0.0389)\end{array}$ & $\begin{array}{l}0.893 * * * \\
(0.0685)\end{array}$ & $\begin{array}{l}0.0652^{*} \\
(0.0365)\end{array}$ & $\begin{array}{c}0.0331 \\
(0.0306)\end{array}$ & $\begin{array}{l}0.721^{* * *} \\
(0.0576)\end{array}$ & $\begin{array}{l}0.171^{* * *} \\
(0.0491)\end{array}$ & $\begin{array}{l}0.137 * * \\
(0.0538)\end{array}$ \\
\hline$N F A$ & & $\begin{array}{c}-0.0648 * * * \\
(0.0243)\end{array}$ & $\begin{array}{c}-0.0805^{* * *} \\
(0.0213)\end{array}$ & & $\begin{array}{c}-0.0775^{* * *} \\
(0.0269)\end{array}$ & $\begin{array}{c}-0.0668 * * * \\
(0.0189)\end{array}$ & & $\begin{array}{c}-0.0807 * * * \\
(0.0215)\end{array}$ & $\begin{array}{r}-0.110 * * * \\
(0.0209)\end{array}$ \\
\hline TOT & & & $\begin{array}{c}0.374 * * * \\
(0.102)\end{array}$ & & & $\begin{array}{c}-0.198 * * * \\
(0.0558)\end{array}$ & & & $\begin{array}{c}0.329 * * * \\
(0.116)\end{array}$ \\
\hline \multicolumn{10}{|l|}{ Short-run dynamics } \\
\hline e.c. & $\begin{array}{c}-0.219 * * * \\
(0.0814)\end{array}$ & $\begin{array}{c}-0.244 * * * \\
(0.0462)\end{array}$ & $\begin{array}{c}-0.233^{*} * * \\
(0.0409)\end{array}$ & $\begin{array}{c}-0.193 * * * \\
(0.0722)\end{array}$ & $\begin{array}{c}-0.241^{* * *} \\
(0.0509)\end{array}$ & $\begin{array}{c}-0.256 * * * \\
(0.0688)\end{array}$ & $\begin{array}{c}-0.255^{* * *} \\
(0.0907)\end{array}$ & $\begin{array}{c}-0.247^{* * *} \\
(0.0476)\end{array}$ & $\begin{array}{c}-0.192 * * * \\
(0.0428)\end{array}$ \\
\hline$D . B S$ & $\begin{array}{c}-0.214^{* * *} \\
(0.0800)\end{array}$ & $\begin{array}{c}-0.194 * * * \\
(0.0737)\end{array}$ & $\begin{array}{c}-0.126 * * * \\
(0.0474)\end{array}$ & $\begin{array}{r}-0.0912 \\
(0.142)\end{array}$ & $\begin{array}{l}-0.0740 \\
(0.0684)\end{array}$ & $\begin{array}{l}-0.0932 * \\
(0.0535)\end{array}$ & $\begin{array}{c}-0.221^{* * *} \\
(0.0745)\end{array}$ & $\begin{array}{l}-0.0987^{*} \\
(0.0566)\end{array}$ & $\begin{array}{r}-0.135 * * * \\
(0.0384)\end{array}$ \\
\hline \multirow[t]{2}{*}{$D . N F A$} & & $\begin{array}{l}-0.0250 \\
(0.0402)\end{array}$ & $\begin{array}{l}-0.0233 \\
(0.0425)\end{array}$ & & $\begin{array}{l}-0.0409 \\
(0.0387)\end{array}$ & $\begin{array}{l}-0.0298 \\
(0.0467)\end{array}$ & & $\begin{array}{l}-0.0763 \\
(0.0653)\end{array}$ & $\begin{array}{l}-0.0366 \\
(0.0400)\end{array}$ \\
\hline & & & $\begin{array}{l}0.225 * * * \\
(0.0790)\end{array}$ & & & $\begin{array}{l}0.330 * * * \\
(0.0936)\end{array}$ & & & $\begin{array}{l}0.206 * * * \\
(0.0619)\end{array}$ \\
\hline Constant & $\begin{array}{c}1.038 * * * \\
(0.395)\end{array}$ & $\begin{array}{l}1.421^{* * *} \\
(0.268)\end{array}$ & $\begin{array}{c}0.663 * * * \\
(0.116)\end{array}$ & $\begin{array}{c}0.906 * * * \\
(0.350)\end{array}$ & $\begin{array}{c}1.269 * * * \\
(0.268)\end{array}$ & $\begin{array}{c}1.404^{* * *} \\
(0.379)\end{array}$ & $\begin{array}{c}1.193 * * * \\
(0.432)\end{array}$ & $\begin{array}{c}1.436 * * * \\
(0.274)\end{array}$ & $\begin{array}{c}0.584^{* * *} \\
(0.131)\end{array}$ \\
\hline
\end{tabular}


Table B.2.2.6 - Equilibrium exchange rate model estimations (WAEMU)

\begin{tabular}{|c|c|c|c|c|c|c|c|c|c|}
\hline \multirow{2}{*}{$\begin{array}{l}\begin{array}{c}\text { Weighting } \\
\text { system }\end{array} \\
\text { Model }\end{array}$} & \multicolumn{6}{|c|}{ Fixed } & \multicolumn{3}{|c|}{$\begin{array}{c}\text { Time-varying weights } \\
\text { (5-year averages) }\end{array}$} \\
\hline & (1) & $(2)$ & (3) & (1) & $(2)$ & (3) & (1) & $(2)$ & (3) \\
\hline \multicolumn{10}{|c|}{ Long-run dynamics } \\
\hline$B S$ & $\begin{array}{c}0.104 \\
(0.108)\end{array}$ & $\begin{array}{c}-6.037 * * * \\
(1.299)\end{array}$ & $\begin{array}{l}0.0211 \\
(0.188)\end{array}$ & $\begin{array}{l}0.184 * * \\
(0.0836)\end{array}$ & $\begin{array}{l}0.189 * * \\
(0.0785)\end{array}$ & $\begin{array}{l}0.169 * \\
(0.0966)\end{array}$ & $\begin{array}{c}0.120 \\
(0.121)\end{array}$ & $\begin{array}{c}-1.094 * * * \\
(0.246)\end{array}$ & $\begin{array}{c}-0.398 * * \\
(0.187)\end{array}$ \\
\hline$N F A$ & & $\begin{array}{l}-2.761^{* * *} \\
(0.832)\end{array}$ & $\begin{array}{l}0.138 \\
(0.106)\end{array}$ & & $\begin{array}{l}0.199 * * \\
(0.101)\end{array}$ & $\begin{array}{c}0.245^{* *} \\
(0.103)\end{array}$ & & $\begin{array}{c}1.297 * * * \\
(0.265)\end{array}$ & $\begin{array}{c}0.0209 \\
(0.0483)\end{array}$ \\
\hline TOT & & & $\begin{array}{l}0.445 * * \\
(0.198)\end{array}$ & & & $\begin{array}{c}0.243^{* *} \\
(0.119)\end{array}$ & & & $\begin{array}{c}0.678 * * * \\
(0.188)\end{array}$ \\
\hline \multicolumn{10}{|c|}{ Short-run dynamics } \\
\hline e.c. & $\begin{array}{c}-0.175^{* * *} \\
(0.0354)\end{array}$ & $\begin{array}{l}-0.0362 \\
(0.0388)\end{array}$ & $\begin{array}{c}-0.182 * * * \\
(0.0407)\end{array}$ & $\begin{array}{c}-0.196 * * * \\
(0.0328)\end{array}$ & $\begin{array}{c}-0.186 * * * \\
(0.0337)\end{array}$ & $\begin{array}{c}-0.230 * * * \\
(0.0465)\end{array}$ & $\begin{array}{c}-0.185 * * * \\
(0.0361)\end{array}$ & $\begin{array}{c}-0.0800 * \\
(0.0416)\end{array}$ & $\begin{array}{c}-0.172 * * * \\
(0.0401)\end{array}$ \\
\hline$D . B S$ & $\begin{array}{l}-0.546 \\
(0.462)\end{array}$ & $\begin{array}{l}-0.390 \\
(0.298)\end{array}$ & $\begin{array}{l}-0.665 \\
(0.570)\end{array}$ & $\begin{array}{c}-0.309 * * \\
(0.157)\end{array}$ & $\begin{array}{c}-0.317^{* *} \\
(0.153)\end{array}$ & $\begin{array}{l}-0.379^{*} \\
(0.228)\end{array}$ & $\begin{array}{l}-0.122 \\
(0.125)\end{array}$ & $\begin{array}{l}-0.0119 \\
(0.108)\end{array}$ & $\begin{array}{l}-0.145 \\
(0.227)\end{array}$ \\
\hline$D . N F A$ & & $\begin{array}{c}0.373 * * * \\
(0.115)\end{array}$ & $\begin{array}{c}0.351 * * \\
(0.137)\end{array}$ & & $\begin{array}{c}0.288 * * * \\
(0.0927)\end{array}$ & $\begin{array}{c}0.307^{* * *} \\
(0.117)\end{array}$ & & $\begin{array}{c}0.235^{* * *} \\
(0.0513)\end{array}$ & $\begin{array}{c}0.280 * * * \\
(0.0766)\end{array}$ \\
\hline D.TOT & & & $\begin{array}{l}-0.126 \\
(0.179)\end{array}$ & & & $\begin{array}{l}-0.121 \\
(0.114)\end{array}$ & & & $\begin{array}{l}-0.249 \\
(0.307)\end{array}$ \\
\hline Constant & $\begin{array}{c}0.825^{* * *} \\
(0.172)\end{array}$ & $\begin{array}{l}-0.320 \\
(0.345)\end{array}$ & $\begin{array}{c}0.487^{* * *} \\
(0.108)\end{array}$ & $\begin{array}{c}0.957^{* * *} \\
(0.166)\end{array}$ & $\begin{array}{c}0.938 * * * \\
(0.175)\end{array}$ & $\begin{array}{c}0.916^{* * *} \\
(0.188)\end{array}$ & $\begin{array}{c}0.877^{* * *} \\
(0.177)\end{array}$ & $\begin{array}{c}0.232 * * \\
(0.114)\end{array}$ & $\begin{array}{c}0.125^{* * *} \\
(0.0373)\end{array}$ \\
\hline
\end{tabular}

Note: Standard errors are in parentheses. ${ }^{* * *} \mathrm{p}<0.01,{ }^{* *} \mathrm{p}<0.05,{ }^{*} \mathrm{p}<0.1$. "e.c." denotes the error-correction term. 
B.2.3. Geographical regions

Table B.2.3.1 - Equilibrium exchange rate model estimations (Africa)

\begin{tabular}{|c|c|c|c|c|c|c|c|c|c|}
\hline \multirow{3}{*}{$\begin{array}{l}\begin{array}{c}\text { Weighting } \\
\text { system }\end{array} \\
\text { Model }\end{array}$} & \multicolumn{6}{|c|}{ Fixed } & \multirow{2}{*}{\multicolumn{3}{|c|}{$\begin{array}{l}\text { Time-varying weights } \\
\text { (5-year averages) }\end{array}$}} \\
\hline & \multicolumn{3}{|c|}{$(1973-2016)$} & \multicolumn{3}{|c|}{$(2008-2012)$} & & & \\
\hline & (1) & $(2)$ & (3) & (1) & $(2)$ & (3) & (1) & $(2)$ & (3) \\
\hline \multicolumn{10}{|c|}{ Long-run dynamics } \\
\hline$B S$ & $\begin{array}{c}0.0367 \\
(0.0478)\end{array}$ & $\begin{array}{l}0.287 * * * \\
(0.0492)\end{array}$ & $\begin{array}{l}0.232 * * * \\
(0.0393)\end{array}$ & $\begin{array}{l}0.237 * * * \\
(0.0396)\end{array}$ & $\begin{array}{l}0.213 * * * \\
(0.0416)\end{array}$ & $\begin{array}{l}0.156 * * * \\
(0.0327)\end{array}$ & $\begin{array}{l}0.00161 \\
(0.0367)\end{array}$ & $\begin{array}{l}0.119 * * * \\
(0.0327)\end{array}$ & $\begin{array}{l}0.146 * * * \\
(0.0369)\end{array}$ \\
\hline$N F A$ & & $\begin{array}{l}0.206 * * * \\
(0.0295)\end{array}$ & $\begin{array}{l}0.148 * * * \\
(0.0216)\end{array}$ & & $\begin{array}{l}0.178 * * * \\
(0.0268)\end{array}$ & $\begin{array}{l}0.115^{* * *} \\
(0.0172)\end{array}$ & & $\begin{array}{l}0.255^{* * *} \\
(0.0350)\end{array}$ & $\begin{array}{l}0.156 * * * \\
(0.0244)\end{array}$ \\
\hline TOT & & & $\begin{array}{c}0.0393 \\
(0.0502)\end{array}$ & & & $\begin{array}{l}-0.0252 \\
(0.0438)\end{array}$ & & & $\begin{array}{c}-0.106 * * \\
(0.0480)\end{array}$ \\
\hline \multicolumn{10}{|c|}{ Short-run dynamics } \\
\hline e.c. & $\begin{array}{c}-0.145^{* * *} \\
(0.0253)\end{array}$ & $\begin{array}{c}-0.148 * * * \\
(0.0244)\end{array}$ & $\begin{array}{c}-0.187^{* * *} \\
(0.0240)\end{array}$ & $\begin{array}{c}-0.165^{* * *} \\
(0.0258)\end{array}$ & $\begin{array}{c}-0.172^{* * *} \\
(0.0266)\end{array}$ & $\begin{array}{c}-0.221^{* * *} \\
(0.0299)\end{array}$ & $\begin{array}{c}-0.145^{* * *} \\
(0.0258)\end{array}$ & $\begin{array}{c}-0.138 * * * \\
(0.0251)\end{array}$ & $\begin{array}{c}-0.175 * * * \\
(0.0246)\end{array}$ \\
\hline$D . B S$ & $\begin{array}{c}0.211 \\
(0.324)\end{array}$ & $\begin{array}{c}0.128 \\
(0.362)\end{array}$ & $\begin{array}{l}0.0742 \\
(0.325)\end{array}$ & $\begin{array}{c}0.197 \\
(0.306)\end{array}$ & $\begin{array}{c}0.130 \\
(0.338)\end{array}$ & $\begin{array}{c}0.141 \\
(0.293)\end{array}$ & $\begin{array}{c}0.312 \\
(0.294)\end{array}$ & $\begin{array}{c}0.303 \\
(0.371)\end{array}$ & $\begin{array}{c}0.264 \\
(0.341)\end{array}$ \\
\hline$D . N F A$ & & $\begin{array}{c}0.126 * * * \\
(0.0355)\end{array}$ & $\begin{array}{c}0.122 * * * \\
(0.0397)\end{array}$ & & $\begin{array}{c}0.122 * * * \\
(0.0357)\end{array}$ & $\begin{array}{c}0.116 * * * \\
(0.0385)\end{array}$ & & $\begin{array}{c}0.141^{* * *} \\
(0.0464)\end{array}$ & $\begin{array}{l}0.134 * * \\
(0.0543)\end{array}$ \\
\hline D.TOT & & & $\begin{array}{c}0.290 \\
(0.378)\end{array}$ & & & $\begin{array}{l}0.355 \\
(0.401)\end{array}$ & & & $\begin{array}{c}0.504 \\
(0.619)\end{array}$ \\
\hline Constant & $\begin{array}{c}0.724 * * * \\
(0.124)\end{array}$ & $\begin{array}{c}0.845 * * * \\
(0.141)\end{array}$ & $\begin{array}{c}0.955 * * * \\
(0.135)\end{array}$ & $\begin{array}{c}0.894 * * * \\
(0.140)\end{array}$ & $\begin{array}{c}0.951 * * * \\
(0.146)\end{array}$ & $\begin{array}{c}1.146 * * * \\
(0.164)\end{array}$ & $\begin{array}{c}0.723 * * * \\
(0.126)\end{array}$ & $\begin{array}{c}0.765^{* * *} \\
(0.138)\end{array}$ & $\begin{array}{c}0.991^{* * *} \\
(0.147)\end{array}$ \\
\hline
\end{tabular}

Note: Standard errors are in parentheses. ${ }^{* * *} \mathrm{p}<0.01,{ }^{* *} \mathrm{p}<0.05, * \mathrm{p}<0.1$. "e.c." denotes the error-correction term. 
Table B.2.3.2 - Equilibrium exchange rate model estimations (America)

\begin{tabular}{|c|c|c|c|c|c|c|c|c|}
\hline \multirow{3}{*}{$\begin{array}{c}\begin{array}{c}\text { Weighting } \\
\text { system }\end{array} \\
\text { Model } \\
\end{array}$} & \multicolumn{5}{|c|}{ Fixed } & \multirow{2}{*}{\multicolumn{3}{|c|}{$\begin{array}{c}\text { Time-varying weights } \\
\text { (5-year averages) }\end{array}$}} \\
\hline & \multicolumn{3}{|c|}{$(1973-2016)$} & \multicolumn{2}{|c|}{$(2008-2012)$} & & & \\
\hline & (1) & $(2)$ & (3) & (1) & (2) (3) & (1) & $(2)$ & (3) \\
\hline \multicolumn{9}{|c|}{ Long-run dynamics } \\
\hline$B S$ & $\begin{array}{l}-0.0113 \\
(0.0267)\end{array}$ & $\begin{array}{l}-0.0118 \\
(0.0659)\end{array}$ & $\begin{array}{l}0.0415 \\
(0.120)\end{array}$ & $\begin{array}{c}0.0203 \\
(0.0283)\end{array}$ & $\begin{array}{c}0.0239 \\
(0.0823)\end{array}$ & $\begin{array}{l}-0.0269 \\
(0.0281)\end{array}$ & $\begin{array}{l}-0.0856 \\
(0.0658)\end{array}$ & $\begin{array}{l}0.355^{* * *} \\
(0.0705)\end{array}$ \\
\hline$N F A$ & & $\begin{array}{l}0.239 * * * \\
(0.0289)\end{array}$ & $\begin{array}{c}1.135^{* * *} * \\
(0.148)\end{array}$ & & $\begin{array}{c}1.134 * * * \\
(0.139)\end{array}$ & & $\begin{array}{c}0.218 * * * \\
(0.0288)\end{array}$ & $\begin{array}{l}0.138 * * * \\
(0.0209)\end{array}$ \\
\hline TOT & & & $\begin{array}{c}0.0825 \\
(0.115)\end{array}$ & & $\begin{array}{l}0.317 * * * \\
(0.0954)\end{array}$ & & & $\begin{array}{c}0.164 * * \\
(0.0697)\end{array}$ \\
\hline \multicolumn{9}{|c|}{ Short-run dynamics } \\
\hline e.c. & $\begin{array}{c}-0.127 * * * \\
(0.0261)\end{array}$ & $\begin{array}{c}-0.0872 * * * \\
(0.0242)\end{array}$ & $\begin{array}{c}-0.0853 * * * \\
(0.0191)\end{array}$ & $\begin{array}{c}-0.129 * * * \\
(0.0262)\end{array}$ & $\begin{array}{c}-0.0894 * * * \\
(0.0220)\end{array}$ & $\begin{array}{c}-0.127^{* * *} \\
(0.0254)\end{array}$ & $\begin{array}{c}-0.0900 * * * \\
(0.0231)\end{array}$ & $\begin{array}{c}-0.144 * * * \\
(0.0275)\end{array}$ \\
\hline$D . B S$ & $\begin{array}{c}0.354^{* *} \\
(0.169)\end{array}$ & $\begin{array}{c}0.326^{* *} \\
(0.142)\end{array}$ & $\begin{array}{c}0.691 \\
(0.558)\end{array}$ & $\begin{array}{l}0.303^{*} \\
(0.165)\end{array}$ & $\begin{array}{c}0.639 \\
(0.521)\end{array}$ & $\begin{array}{c}0.336 * * \\
(0.152)\end{array}$ & $\begin{array}{c}0.320 * * \\
(0.129)\end{array}$ & $\begin{array}{c}0.582 \\
(0.393)\end{array}$ \\
\hline D.NFA & & $\begin{array}{l}-0.0259 \\
(0.114)\end{array}$ & $\begin{array}{l}0.00632 \\
(0.0417)\end{array}$ & & $\begin{array}{c}0.0164 \\
(0.0479)\end{array}$ & & $\begin{array}{r}-0.0372 \\
(0.115)\end{array}$ & $\begin{array}{c}0.0801 \\
(0.0514)\end{array}$ \\
\hline D.TOT & & & $\begin{array}{c}-0.0304 \\
(0.0493)\end{array}$ & & $\begin{array}{l}-0.0610 \\
(0.0465)\end{array}$ & & & $\begin{array}{l}-0.0652 \\
(0.0467)\end{array}$ \\
\hline Constant & $\begin{array}{c}0.591^{* * *} \\
(0.115)\end{array}$ & $\begin{array}{c}0.425 * * * \\
(0.105)\end{array}$ & $\begin{array}{c}0.389 * * * \\
(0.0862)\end{array}$ & $\begin{array}{c}0.605 * * * \\
(0.116)\end{array}$ & $\begin{array}{l}0.315^{* * *} * \\
(0.0752)\end{array}$ & $\begin{array}{c}0.588 * * * \\
(0.112)\end{array}$ & $\begin{array}{l}0.428 * * * \\
(0.0985)\end{array}$ & $\begin{array}{c}-0.144 * * * \\
(0.0275)\end{array}$ \\
\hline
\end{tabular}

Note: Standard errors are in parentheses. ${ }^{* * *} \mathrm{p}<0.01,{ }^{* *} \mathrm{p}<0.05, * \mathrm{p}<0.1$. "e.c." denotes the error-correction term. 
Table B.2.3.3 - Equilibrium exchange rate model estimations (Asia)

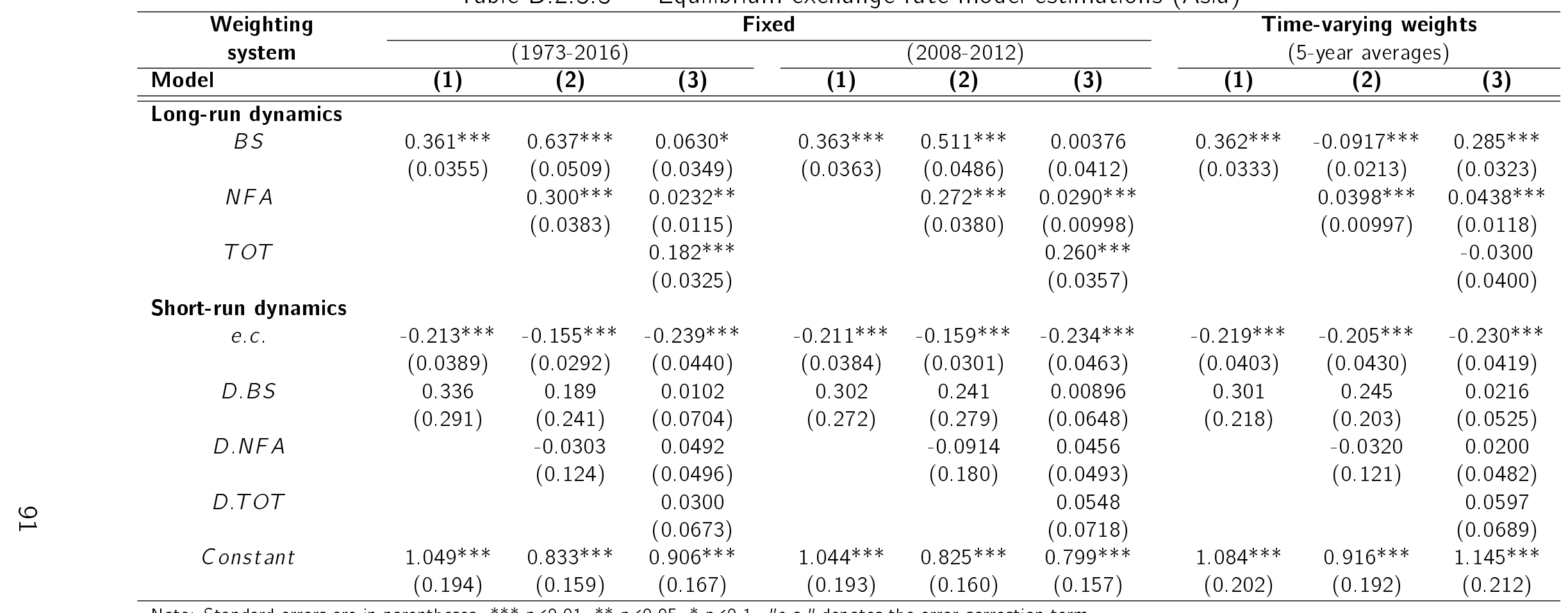

Note: Standard errors are in parentheses. ${ }^{* * *} \mathrm{p}<0.01,{ }^{* *} \mathrm{p}<0.05, * \mathrm{p}<0.1$. "e.c." denotes the error-correction term. 
Table B.2.3.4 - Equilibrium exchange rate model estimations (Europe)

\begin{tabular}{|c|c|c|c|c|c|c|c|c|c|}
\hline \multirow{3}{*}{$\begin{array}{c}\begin{array}{c}\text { Weighting } \\
\text { system }\end{array} \\
\text { Model }\end{array}$} & \multicolumn{6}{|c|}{ Fixed } & \multirow{2}{*}{\multicolumn{3}{|c|}{$\begin{array}{l}\text { Time-varying weights } \\
\text { (5-year averages) }\end{array}$}} \\
\hline & \multicolumn{3}{|c|}{$(1973-2016)$} & \multicolumn{3}{|c|}{$(2008-2012)$} & & & \\
\hline & (1) & (2) & (3) & (1) & (2) & (3) & (1) & (2) & (3) \\
\hline \multicolumn{10}{|c|}{ Long-run dynamics } \\
\hline$B S$ & $\begin{array}{l}0.445^{* * *} \\
(0.0447)\end{array}$ & $\begin{array}{l}0.495^{* * *} \\
(0.0576)\end{array}$ & $\begin{array}{l}0.179 * * * \\
(0.0398)\end{array}$ & $\begin{array}{l}0.233^{* * *} \\
(0.0424)\end{array}$ & $\begin{array}{l}0.358^{* * *} \\
(0.0580)\end{array}$ & $\begin{array}{c}0.0348 \\
(0.0283)\end{array}$ & $\begin{array}{l}0.505^{* * *} \\
(0.0421)\end{array}$ & $\begin{array}{l}0.339 * * * \\
(0.0459)\end{array}$ & $\begin{array}{l}0.172^{* * *} \\
(0.0311)\end{array}$ \\
\hline NFA & & $\begin{array}{c}-0.135 * * * \\
(0.0236)\end{array}$ & $\begin{array}{c}-0.168 * * * \\
(0.0211)\end{array}$ & & $\begin{array}{c}-0.103 * * * \\
(0.0236)\end{array}$ & $\begin{array}{c}-0.0535^{* * *} * \\
(0.0153)\end{array}$ & & $\begin{array}{c}-0.0997^{* * *} \\
(0.0175)\end{array}$ & $\begin{array}{c}0.0160 * \\
(0.00884)\end{array}$ \\
\hline TOT & & & $\begin{array}{c}0.604 * * * \\
(0.0717)\end{array}$ & & & $\begin{array}{c}-0.129 * * \\
(0.0534)\end{array}$ & & & $\begin{array}{c}0.701^{* * *} \\
(0.0747)\end{array}$ \\
\hline \multicolumn{10}{|c|}{ Short-run dynamics } \\
\hline e.c. & $\begin{array}{c}-0.299 * * * \\
(0.0523)\end{array}$ & $\begin{array}{c}-0.212 * * * \\
(0.0432)\end{array}$ & $\begin{array}{l}-0.0567 \\
(0.157)\end{array}$ & $\begin{array}{c}-0.292^{* * *} \\
(0.0460)\end{array}$ & $\begin{array}{c}-0.218^{* * *} \\
(0.0436)\end{array}$ & $\begin{array}{l}-0.137 \\
(0.138)\end{array}$ & $\begin{array}{c}-0.313^{* * *} \\
(0.0566)\end{array}$ & $\begin{array}{c}-0.227^{* * *} \\
(0.0411)\end{array}$ & $\begin{array}{r}-0.212^{* * *} \\
(0.0791)\end{array}$ \\
\hline$D . B S$ & $\begin{array}{c}0.102 \\
(0.258)\end{array}$ & $\begin{array}{c}-0.106 \\
(0.0873)\end{array}$ & $\begin{array}{c}0.699 \\
(0.793)\end{array}$ & $\begin{array}{c}0.115 \\
(0.226)\end{array}$ & $\begin{array}{l}-0.0881 \\
(0.0948)\end{array}$ & $\begin{array}{c}0.732 \\
(0.763)\end{array}$ & $\begin{array}{c}0.187 \\
(0.308)\end{array}$ & $\begin{array}{c}0.149 \\
(0.178)\end{array}$ & $\begin{array}{c}0.184 \\
(0.257)\end{array}$ \\
\hline D.NFA & & $\begin{array}{c}-0.0352 \\
(0.0350)\end{array}$ & $\begin{array}{l}-0.149 \\
(0.153)\end{array}$ & & $\begin{array}{c}-0.0241 \\
(0.0312)\end{array}$ & $\begin{array}{l}-0.182 \\
(0.146)\end{array}$ & & $\begin{array}{l}-0.0530 \\
(0.0416)\end{array}$ & $\begin{array}{l}-0.105^{*} \\
(0.0595)\end{array}$ \\
\hline D.TOT & & & $\begin{array}{l}-1.006 \\
(1.188)\end{array}$ & & & $\begin{array}{l}-1.030 \\
(1.290)\end{array}$ & & & $\begin{array}{l}-0.629 \\
(0.671)\end{array}$ \\
\hline Constant & $\begin{array}{c}1.423 * * * \\
(0.253)\end{array}$ & $\begin{array}{c}0.994 * * * \\
(0.205)\end{array}$ & $\begin{array}{l}0.0638 \\
(0.326)\end{array}$ & $\begin{array}{c}1.363 * * * \\
(0.217)\end{array}$ & $\begin{array}{c}1.011^{* * *} \\
(0.205)\end{array}$ & $\begin{array}{c}0.685 \\
(0.742)\end{array}$ & $\begin{array}{c}1.492 * * * \\
(0.274)\end{array}$ & $\begin{array}{c}1.049 * * * \\
(0.193)\end{array}$ & $\begin{array}{l}0.284^{* *} \\
(0.135)\end{array}$ \\
\hline
\end{tabular}

Note: Standard errors are in parentheses. ${ }^{* * *} \mathrm{p}<0.01, * * \mathrm{p}<0.05, * \mathrm{p}<0.1$. "e.c." denotes the error-correction term. 
Table B.2.3.5 - Equilibrium exchange rate model estimations (Oceania)

\begin{tabular}{|c|c|c|c|c|c|c|c|c|c|}
\hline \multirow{3}{*}{$\begin{array}{c}\begin{array}{c}\text { Weighting } \\
\text { system }\end{array} \\
\text { Model } \\
\end{array}$} & \multicolumn{6}{|c|}{ Fixed } & \multirow{2}{*}{\multicolumn{3}{|c|}{$\begin{array}{c}\text { Time-varying weights } \\
\text { (5-year averages) }\end{array}$}} \\
\hline & \multicolumn{3}{|c|}{$(1973-2016)$} & \multicolumn{3}{|c|}{$(2008-2012)$} & & & \\
\hline & (1) & $(2)$ & (3) & (1) & $(2)$ & (3) & (1) & (2) & (3) \\
\hline \multicolumn{10}{|c|}{ Long-run dynamics } \\
\hline$B S$ & $\begin{array}{c}0.883 * * * \\
(0.108)\end{array}$ & $\begin{array}{c}0.344^{* * *} \\
(0.115)\end{array}$ & $\begin{array}{c}0.572 * * * \\
(0.156)\end{array}$ & $\begin{array}{c}1.335^{* * *} \\
(0.225)\end{array}$ & $\begin{array}{c}1.422 * * * \\
(0.193)\end{array}$ & $\begin{array}{c}0.461 * * * \\
(0.134)\end{array}$ & & $\begin{array}{l}0.521^{* * *} \\
(0.0532)\end{array}$ & $\begin{array}{c}0.416^{* * *} \\
(0.156)\end{array}$ \\
\hline$N F A$ & & $\begin{array}{l}0.348 * * * \\
(0.0688)\end{array}$ & $\begin{array}{c}0.0820 \\
(0.0777)\end{array}$ & & $\begin{array}{c}-0.180 * * * \\
(0.0652)\end{array}$ & $\begin{array}{l}-0.0418 \\
(0.0728)\end{array}$ & & $\begin{array}{c}-0.108 * * * \\
(0.0400)\end{array}$ & $\begin{array}{c}0.101 \\
(0.0726)\end{array}$ \\
\hline TOT & & & $\begin{array}{c}1.664^{* * *} \\
(0.192)\end{array}$ & & & $\begin{array}{c}1.688 * * * \\
(0.212)\end{array}$ & & & $\begin{array}{c}0.892^{* * *} \\
(0.132)\end{array}$ \\
\hline \multicolumn{10}{|c|}{ Short-run dynamics } \\
\hline e.c. & $\begin{array}{c}-0.119 * * \\
(0.0478)\end{array}$ & $\begin{array}{c}-0.115^{* *} \\
(0.0477)\end{array}$ & $\begin{array}{l}-0.0677 \\
(0.0536)\end{array}$ & $\begin{array}{c}-0.0634^{*} \\
(0.0366)\end{array}$ & $\begin{array}{c}-0.0805^{* *} \\
(0.0399)\end{array}$ & $\begin{array}{l}-0.0799 \\
(0.0588)\end{array}$ & & $\begin{array}{c}-0.189 * * * \\
(0.0472)\end{array}$ & $\begin{array}{c}-0.136 * * \\
(0.0548)\end{array}$ \\
\hline$D . B S$ & $\begin{array}{l}-0.107 \\
(0.105)\end{array}$ & $\begin{array}{l}-0.154 \\
(0.111)\end{array}$ & $\begin{array}{c}-0.101 \\
(0.191)\end{array}$ & $\begin{array}{c}-0.0903 \\
(0.102)\end{array}$ & $\begin{array}{l}-0.157 \\
(0.109)\end{array}$ & $\begin{array}{c}-0.0644 \\
(0.224)\end{array}$ & & $\begin{array}{l}-0.0410 \\
(0.0722)\end{array}$ & $\begin{array}{l}-0.108^{*} \\
(0.0622)\end{array}$ \\
\hline$D . N F A$ & & $\begin{array}{c}0.0757 \\
(0.116)\end{array}$ & $\begin{array}{c}0.0562 \\
(0.0778)\end{array}$ & & $\begin{array}{c}0.102 \\
(0.101)\end{array}$ & $\begin{array}{c}0.0528 \\
(0.0699)\end{array}$ & & $\begin{array}{c}0.0841 \\
(0.106)\end{array}$ & $\begin{array}{c}0.0466 \\
(0.0842)\end{array}$ \\
\hline D.TOT & & & $\begin{array}{l}-0.0315 \\
(0.0926)\end{array}$ & & & $\begin{array}{l}-0.0655 \\
(0.0940)\end{array}$ & & & $\begin{array}{l}-0.0722 \\
(0.0942)\end{array}$ \\
\hline Constant & $\begin{array}{c}0.760 * * \\
(0.312)\end{array}$ & $\begin{array}{c}0.634 * * \\
(0.277)\end{array}$ & $\begin{array}{c}-0.174 \\
(0.138)\end{array}$ & $\begin{array}{c}0.452^{*} \\
(0.266)\end{array}$ & $\begin{array}{c}0.590 * * \\
(0.290)\end{array}$ & $\begin{array}{l}-0.232 \\
(0.173)\end{array}$ & & $\begin{array}{c}1.034^{* * *} \\
(0.261)\end{array}$ & $\begin{array}{c}0.160 * * * \\
(0.0614)\end{array}$ \\
\hline
\end{tabular}

Note: Standard errors are in parentheses. ${ }^{* * *} \mathrm{p}<0.01,{ }^{* *} \mathrm{p}<0.05, * \mathrm{p}<0.1$. "e.c. " denotes the error-correction term. 


\section{B.2.4. Geographical sub-regions}

Table B.2.4.1 - Equilibrium exchange rate model estimations (Caribbean)

\begin{tabular}{|c|c|c|c|c|c|c|c|c|}
\hline \multirow{3}{*}{$\begin{array}{c}\begin{array}{c}\text { Weighting } \\
\text { system }\end{array} \\
\text { Model }\end{array}$} & \multicolumn{5}{|c|}{ Fixed } & \multirow{2}{*}{\multicolumn{3}{|c|}{$\begin{array}{l}\text { Time-varying weights } \\
\text { (5-year averages) }\end{array}$}} \\
\hline & \multicolumn{3}{|c|}{$(1973-2016)$} & \multicolumn{2}{|c|}{$(2008-2012)$} & & & \\
\hline & (1) & (2) & (3) & (1) & (2) (3) & (1) & (2) & (3) \\
\hline \multicolumn{9}{|c|}{ Long-run dynamics } \\
\hline$B S$ & $\begin{array}{r}-0.00813 \\
(0.0276)\end{array}$ & & $\begin{array}{l}0.232^{*} \\
(0.129)\end{array}$ & $\begin{array}{c}0.0306 \\
(0.0308)\end{array}$ & & $\begin{array}{l}-0.0215 \\
(0.0290)\end{array}$ & & $\begin{array}{c}0.165^{*} \\
(0.0964)\end{array}$ \\
\hline$N F A$ & & & $\begin{array}{c}-0.274 * * * \\
(0.0867)\end{array}$ & & & & & $\begin{array}{r}-0.189 * * * \\
(0.0584)\end{array}$ \\
\hline TOT & & & $\begin{array}{c}0.879 * * * \\
(0.253)\end{array}$ & & & & & $\begin{array}{c}0.666^{* * * *} \\
(0.204)\end{array}$ \\
\hline \multicolumn{9}{|c|}{ Short-run dynamics } \\
\hline e.c. & $\begin{array}{c}-0.150 * * * \\
(0.0263)\end{array}$ & & $\begin{array}{c}-0.116 * * * \\
(0.0336)\end{array}$ & $\begin{array}{c}-0.138 * * * \\
(0.0268)\end{array}$ & & $\begin{array}{c}-0.147^{* * *} \\
(0.0237)\end{array}$ & & $\begin{array}{r}-0.155^{* * *} \\
(0.0549)\end{array}$ \\
\hline D.BS & $\begin{array}{c}-0.100 \\
(0.0950)\end{array}$ & & $\begin{array}{r}-0.0572 \\
(0.159)\end{array}$ & $\begin{array}{c}-0.100 \\
(0.0827)\end{array}$ & & $\begin{array}{l}-0.0697 \\
(0.0926)\end{array}$ & & $\begin{array}{c}0.0368 \\
(0.0999)\end{array}$ \\
\hline D.NFA & & & $\begin{array}{c}0.0930 \\
(0.0825)\end{array}$ & & & & & $\begin{array}{c}0.102 \\
(0.0894)\end{array}$ \\
\hline D.TOT & & & $\begin{array}{c}-0.0601 \\
(0.0950)\end{array}$ & & & & & $\begin{array}{l}-0.0968 \\
(0.0923)\end{array}$ \\
\hline Constant & $\begin{array}{c}0.694 * * * \\
(0.119)\end{array}$ & & $\begin{array}{c}0.0548 * * * \\
(0.0200)\end{array}$ & $\begin{array}{c}0.642^{* * *} \\
(0.123)\end{array}$ & & $\begin{array}{c}0.678^{* * *} \\
(0.107)\end{array}$ & & $\begin{array}{l}0.228 * * * \\
(0.0865)\end{array}$ \\
\hline
\end{tabular}


Table B.2.4.2 - Equilibrium exchange rate model estimations (central America)

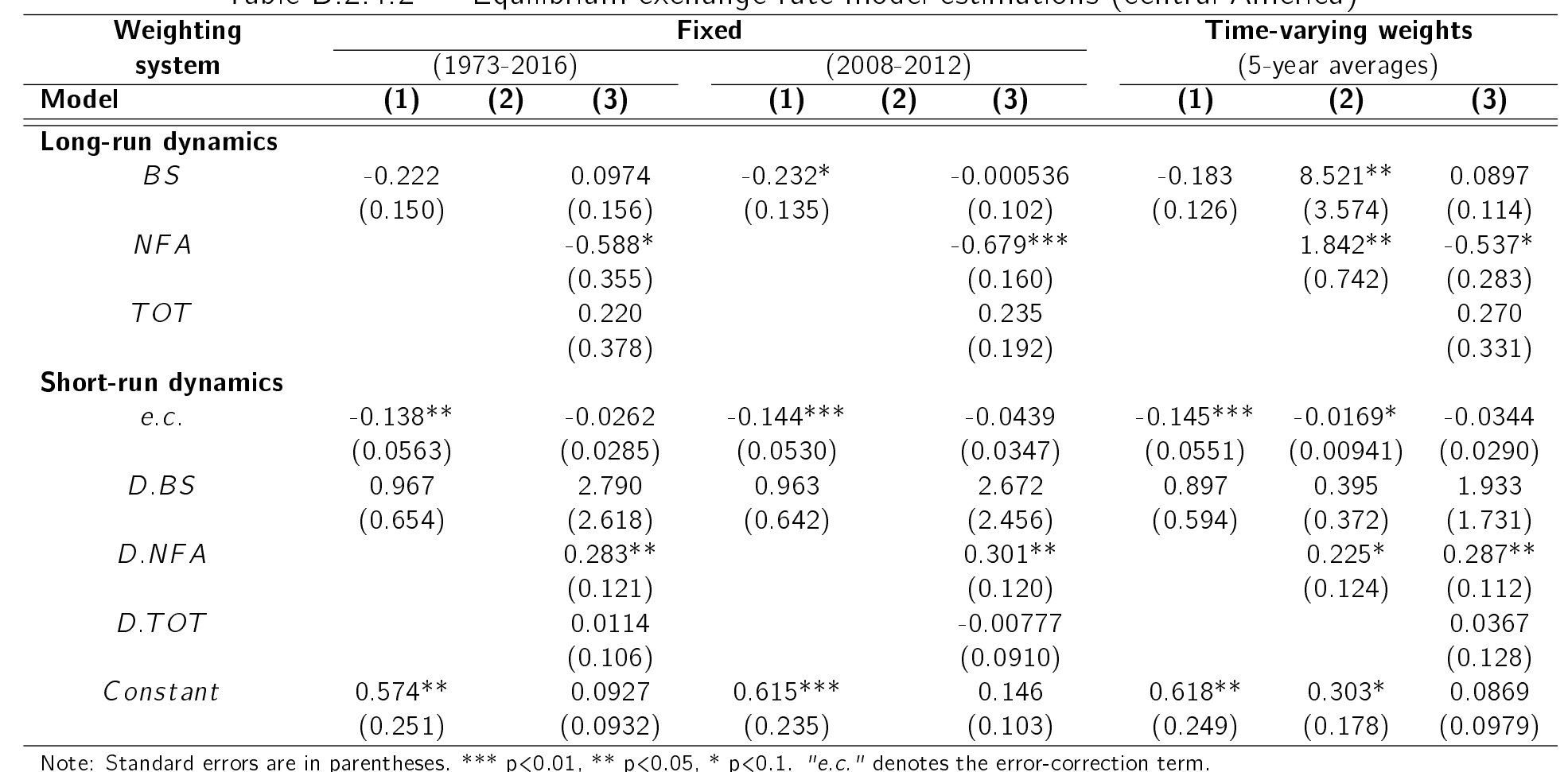


Table B.2.4.3 - Equilibrium exchange rate model estimations (central Asia)

\begin{tabular}{|c|c|c|c|c|c|c|c|c|c|}
\hline \multirow{3}{*}{$\begin{array}{l}\begin{array}{c}\text { Weighting } \\
\text { system }\end{array} \\
\text { Model }\end{array}$} & \multicolumn{6}{|c|}{ Fixed } & \multirow{2}{*}{\multicolumn{3}{|c|}{$\begin{array}{l}\text { Time-varying weights } \\
\text { (5-year averages) }\end{array}$}} \\
\hline & \multicolumn{3}{|c|}{$(1973-2016)$} & \multicolumn{3}{|c|}{$(2008-2012)$} & & & \\
\hline & (1) & $(2)$ & (3) & (1) & $(2)$ & (3) & (1) & $(2)$ & (3) \\
\hline \multicolumn{10}{|c|}{ Long-run dynamics } \\
\hline$B S$ & $\begin{array}{c}0.893 * * * \\
(0.305)\end{array}$ & $\begin{array}{l}-0.458 \\
(0.350)\end{array}$ & $\begin{array}{c}0.0224 \\
(0.0914)\end{array}$ & $\begin{array}{c}0.914^{* * *} \\
(0.182)\end{array}$ & $\begin{array}{c}0.450 \\
(0.313)\end{array}$ & $\begin{array}{l}0.161 * * \\
(0.0781)\end{array}$ & $\begin{array}{c}0.761 * * * \\
(0.260)\end{array}$ & $\begin{array}{l}-0.387 \\
(0.381)\end{array}$ & $\begin{array}{l}-4.305 \\
(2.906)\end{array}$ \\
\hline$N F A$ & & $\begin{array}{c}-0.715^{* * *} \\
(0.166)\end{array}$ & $\begin{array}{l}-0.162^{*} \\
(0.0855)\end{array}$ & & $\begin{array}{c}0.320 * * * \\
(0.123)\end{array}$ & $\begin{array}{c}-0.312^{* * *} \\
(0.0714)\end{array}$ & & $\begin{array}{c}-0.733 * * * \\
(0.160)\end{array}$ & $\begin{array}{c}3.920 \\
(5.160)\end{array}$ \\
\hline TOT & & & $\begin{array}{l}0.254^{* * *} \\
(0.0426)\end{array}$ & & & $\begin{array}{c}0.257 * * * \\
(0.0415)\end{array}$ & & & $\begin{array}{c}-1.377 \\
(1.621)\end{array}$ \\
\hline \multicolumn{10}{|c|}{ Short-run dynamics } \\
\hline e.c. & $\begin{array}{c}-0.417^{* * *} \\
(0.101)\end{array}$ & $\begin{array}{c}-0.419 * * * \\
(0.0693)\end{array}$ & $\begin{array}{l}-0.453^{*} \\
(0.248)\end{array}$ & $\begin{array}{c}-0.451 * * * \\
(0.126)\end{array}$ & $\begin{array}{c}-0.352^{* *} \\
(0.164)\end{array}$ & $\begin{array}{l}-0.542 \\
(0.377)\end{array}$ & $\begin{array}{c}-0.414 * * * \\
(0.0987)\end{array}$ & $\begin{array}{c}-0.433^{* * *} \\
(0.0695)\end{array}$ & $\begin{array}{c}0.0328 \\
(0.0450)\end{array}$ \\
\hline$D . B S$ & $\begin{array}{c}2.301 \\
(2.619)\end{array}$ & $\begin{array}{c}2.591 \\
(2.773)\end{array}$ & $\begin{array}{l}0.0198 \\
(0.205)\end{array}$ & $\begin{array}{l}2.213 \\
(2.446)\end{array}$ & $\begin{array}{l}2.837 \\
(3.111)\end{array}$ & $\begin{array}{l}-0.0646 \\
(0.182)\end{array}$ & $\begin{array}{l}1.710 \\
(1.961)\end{array}$ & $\begin{array}{c}2.131 \\
(2.319)\end{array}$ & $\begin{array}{l}0.0896 \\
(0.189)\end{array}$ \\
\hline$D . N F A$ & & $\begin{array}{l}-0.924 \\
(1.233)\end{array}$ & $\begin{array}{l}0.0325 \\
(0.176)\end{array}$ & & $\begin{array}{l}-2.062 \\
(1.903)\end{array}$ & $\begin{array}{l}0.0854 \\
(0.192)\end{array}$ & & $\begin{array}{l}-0.966 \\
(1.303)\end{array}$ & $\begin{array}{c}0.152 \\
(0.308)\end{array}$ \\
\hline D.TOT & & & $\begin{array}{l}-0.238^{*} \\
(0.143)\end{array}$ & & & $\begin{array}{c}-0.248 * * \\
(0.124)\end{array}$ & & & $\begin{array}{l}-0.0810 \\
(0.0955)\end{array}$ \\
\hline Constant & $\begin{array}{c}2.288 * * * \\
(0.640)\end{array}$ & $\begin{array}{c}1.617^{* * *} \\
(0.372)\end{array}$ & $\begin{array}{l}1.560^{*} \\
(0.827)\end{array}$ & $\begin{array}{c}2.562^{* * *} \\
(0.796)\end{array}$ & $\begin{array}{l}1.768 * * \\
(0.833)\end{array}$ & $\begin{array}{c}1.872 \\
(1.255)\end{array}$ & $\begin{array}{c}2.270^{* * *} \\
(0.619)\end{array}$ & $\begin{array}{c}1.708^{* * *} \\
(0.366)\end{array}$ & $\begin{array}{l}-0.317 \\
(0.389)\end{array}$ \\
\hline
\end{tabular}

Note: Standard errors are in parentheses. ${ }^{* * *} \mathrm{p}<0.01,{ }^{* *} \mathrm{p}<0.05,{ }^{*} \mathrm{p}<0.1$. "e.c." denotes the error-correction term. 
Table B.2.4.4 - Equilibrium exchange rate model estimations (eastern Africa)

\begin{tabular}{|c|c|c|c|c|c|c|c|c|}
\hline \multirow{2}{*}{$\begin{array}{cc}\begin{array}{c}\text { Weighting } \\
\text { system }\end{array} \\
\text { Model } \\
\end{array}$} & \multicolumn{6}{|c|}{ Fixed } & \multicolumn{2}{|c|}{$\begin{array}{c}\text { Time-varying weights } \\
\text { (5-year averages) }\end{array}$} \\
\hline & (1) & (2) & (3) & (1) & (2) & (3) & (1) & (2) (3) \\
\hline \multicolumn{9}{|c|}{ Long-run dynamics } \\
\hline$B S$ & $\begin{array}{c}1.164^{* * *} \\
(0.120)\end{array}$ & $\begin{array}{l}0.329 * * * \\
(0.0640)\end{array}$ & $\begin{array}{c}-1.368 * * * \\
(0.236)\end{array}$ & $\begin{array}{c}0.0663 \\
(0.0752)\end{array}$ & $\begin{array}{l}0.285 * * * \\
(0.0645)\end{array}$ & $\begin{array}{l}-0.148 * \\
(0.0798)\end{array}$ & $\begin{array}{l}3.415^{*} \\
(1.865)\end{array}$ & $\begin{array}{c}-3.372 * * * \\
(0.901)\end{array}$ \\
\hline$N F A$ & & $\begin{array}{c}0.625^{* * *} \\
(0.102)\end{array}$ & $\begin{array}{l}0.190 * * * \\
(0.0735)\end{array}$ & & $\begin{array}{l}0.459 * * * \\
(0.0787)\end{array}$ & $\begin{array}{l}0.140 * * * \\
(0.0284)\end{array}$ & & $\begin{array}{c}0.0763 \\
(0.0902)\end{array}$ \\
\hline TOT & & & $\begin{array}{c}0.710^{* * *} \\
(0.119)\end{array}$ & & & $\begin{array}{c}-0.262^{* * *} \\
(0.0468)\end{array}$ & & $\begin{array}{c}2.327^{* * *} \\
(0.687)\end{array}$ \\
\hline \multicolumn{9}{|c|}{ Short-run dynamics } \\
\hline e.c. & $\begin{array}{c}-0.0573 * \\
(0.0341)\end{array}$ & $\begin{array}{c}-0.0935 * * * \\
(0.0321)\end{array}$ & $\begin{array}{c}-0.101^{* *} \\
(0.0410)\end{array}$ & $\begin{array}{c}-0.140 * * * \\
(0.0405)\end{array}$ & $\begin{array}{c}-0.143^{* * *} \\
(0.0381)\end{array}$ & $\begin{array}{c}-0.186 * * \\
(0.0798)\end{array}$ & $\begin{array}{r}-0.00412 \\
(0.0103)\end{array}$ & $\begin{array}{c}-0.0268 * \\
(0.0140)\end{array}$ \\
\hline$D . B S$ & $\begin{array}{c}0.973 \\
(1.052)\end{array}$ & $\begin{array}{c}1.027 \\
(1.189)\end{array}$ & $\begin{array}{c}1.093 \\
(1.046)\end{array}$ & $\begin{array}{c}0.862 \\
(0.996)\end{array}$ & $\begin{array}{c}0.808 \\
(1.119)\end{array}$ & $\begin{array}{c}0.980 \\
(0.940)\end{array}$ & $\begin{array}{c}1.035 \\
(0.990)\end{array}$ & $\begin{array}{c}1.222 \\
(1.131)\end{array}$ \\
\hline D.NFA & & $\begin{array}{l}0.156 * * \\
(0.0660)\end{array}$ & $\begin{array}{l}0.172 * * \\
(0.0744)\end{array}$ & & $\begin{array}{l}0.145 * * \\
(0.0627)\end{array}$ & $\begin{array}{l}0.162 * * \\
(0.0823)\end{array}$ & & $\begin{array}{c}0.309 * * \\
(0.153)\end{array}$ \\
\hline D.TOT & & & $\begin{array}{c}1.215 \\
(1.232)\end{array}$ & & & $\begin{array}{c}1.366 \\
(1.320)\end{array}$ & & $\begin{array}{c}2.059 \\
(2.065)\end{array}$ \\
\hline Constant & $\begin{array}{l}0.627^{* *} \\
(0.302)\end{array}$ & $\begin{array}{c}0.726 * * * \\
(0.221)\end{array}$ & $\begin{array}{c}-0.144 * * * \\
(0.0489)\end{array}$ & $\begin{array}{c}0.839 * * * \\
(0.209)\end{array}$ & $\begin{array}{c}0.998 * * * \\
(0.231)\end{array}$ & $\begin{array}{l}1.052^{* *} \\
(0.446)\end{array}$ & $\begin{array}{c}0.263 \\
(0.185)\end{array}$ & $\begin{array}{c}-0.349 * \\
(0.198)\end{array}$ \\
\hline
\end{tabular}


Table B.2.4.5 - Equilibrium exchange rate model estimations (eastern Asia)

\begin{tabular}{|c|c|c|c|c|c|c|c|c|c|}
\hline \multirow{3}{*}{$\begin{array}{c}\begin{array}{c}\text { Weighting } \\
\text { system }\end{array} \\
\text { Model } \\
\end{array}$} & \multicolumn{6}{|c|}{ Fixed } & \multirow{2}{*}{\multicolumn{3}{|c|}{$\begin{array}{c}\text { Time-varying weights } \\
\text { (5-year averages) }\end{array}$}} \\
\hline & \multicolumn{3}{|c|}{$(1973-2016)$} & \multicolumn{3}{|c|}{$(2008-2012)$} & & & \\
\hline & (1) & $(2)$ & (3) & (1) & (2) & (3) & (1) & (2) & (3) \\
\hline \multicolumn{10}{|c|}{ Long-run dynamics } \\
\hline$B S$ & $\begin{array}{c}0.580 * * * \\
(0.191)\end{array}$ & $\begin{array}{c}0.0298 \\
(0.0836)\end{array}$ & $\begin{array}{c}0.133 \\
(0.0814)\end{array}$ & $\begin{array}{c}0.640 * * * \\
(0.219)\end{array}$ & $\begin{array}{c}0.207^{* *} \\
(0.102)\end{array}$ & $\begin{array}{l}0.203^{* *} \\
(0.0930)\end{array}$ & $\begin{array}{c}0.611^{* * *} \\
(0.207)\end{array}$ & $\begin{array}{l}-0.0514 \\
(0.0436)\end{array}$ & $\begin{array}{c}0.0196 \\
(0.0392)\end{array}$ \\
\hline$N F A$ & & $\begin{array}{c}0.226 \\
(0.154)\end{array}$ & $\begin{array}{l}-0.0822 \\
(0.0658)\end{array}$ & & $\begin{array}{c}0.124 \\
(0.0918)\end{array}$ & $\begin{array}{l}-0.0309 \\
(0.0292)\end{array}$ & & $\begin{array}{c}0.185 \\
(0.115)\end{array}$ & $\begin{array}{l}-0.0214 \\
(0.0333)\end{array}$ \\
\hline TOT & & & $\begin{array}{c}0.158 \\
(0.141)\end{array}$ & & & $\begin{array}{c}0.0220 \\
(0.0660)\end{array}$ & & & $\begin{array}{l}0.171^{* *} \\
(0.0739)\end{array}$ \\
\hline \multicolumn{10}{|c|}{ Short-run dynamics } \\
\hline e.c. & $\begin{array}{c}-0.0907^{* * *} \\
(0.0159)\end{array}$ & $\begin{array}{c}-0.175^{* * *} \\
(0.0572)\end{array}$ & $\begin{array}{c}-0.229 * * * \\
(0.0786)\end{array}$ & $\begin{array}{c}-0.0981^{* * *} \\
(0.0211)\end{array}$ & $\begin{array}{c}-0.213^{* * *} \\
(0.0594)\end{array}$ & $\begin{array}{c}-0.334^{* *} \\
(0.156)\end{array}$ & $\begin{array}{c}-0.0984 * * * \\
(0.0311)\end{array}$ & $\begin{array}{c}-0.220 * * * \\
(0.0737)\end{array}$ & $\begin{array}{c}-0.262^{* *} \\
(0.108)\end{array}$ \\
\hline$D . B S$ & $\begin{array}{c}0.332 * * * \\
(0.123)\end{array}$ & $\begin{array}{c}0.108 \\
(0.389)\end{array}$ & $\begin{array}{c}0.284^{* * *} * \\
(0.0909)\end{array}$ & $\begin{array}{c}0.251^{* *} \\
(0.0991)\end{array}$ & $\begin{array}{c}0.139 \\
(0.249)\end{array}$ & $\begin{array}{l}0.241^{* *} \\
(0.102)\end{array}$ & $\begin{array}{c}0.293 * * * \\
(0.108)\end{array}$ & $\begin{array}{c}0.135 \\
(0.230)\end{array}$ & $\begin{array}{l}0.296^{* * *} \\
(0.0489)\end{array}$ \\
\hline D.NFA & & $\begin{array}{l}-0.180 * \\
(0.108)\end{array}$ & $\begin{array}{l}-0.178 \\
(0.192)\end{array}$ & & $\begin{array}{l}-0.163^{*} \\
(0.0902)\end{array}$ & $\begin{array}{l}-0.222 \\
(0.188)\end{array}$ & & $\begin{array}{c}-0.253^{* * *} * \\
(0.0939)\end{array}$ & $\begin{array}{l}-0.258 \\
(0.169)\end{array}$ \\
\hline D.TOT & & & $\begin{array}{l}0.624^{*} \\
(0.367)\end{array}$ & & & $\begin{array}{l}0.605^{*} \\
(0.341)\end{array}$ & & & $\begin{array}{l}0.636^{*} \\
(0.368)\end{array}$ \\
\hline Constant & $\begin{array}{l}0.422 * * * \\
(0.0773)\end{array}$ & $\begin{array}{c}0.824 * * * \\
(0.275)\end{array}$ & $\begin{array}{c}0.909 * * * \\
(0.308)\end{array}$ & $\begin{array}{c}0.449 * * * \\
(0.106)\end{array}$ & $\begin{array}{c}1.005 * * * \\
(0.290)\end{array}$ & $\begin{array}{l}1.529 * * \\
(0.716)\end{array}$ & $\begin{array}{c}0.436 * * * \\
(0.133)\end{array}$ & $\begin{array}{c}1.020 * * * \\
(0.353)\end{array}$ & $\begin{array}{l}1.002^{* *} \\
(0.410)\end{array}$ \\
\hline
\end{tabular}

Note: Standard errors are in parentheses. ${ }^{* * *} \mathrm{p}<0.01,{ }^{* *} \mathrm{p}<0.05,{ }^{*} \mathrm{p}<0.1$. "e.c." denotes the error-correction term. 
Table B.2.4.6 - Equilibrium exchange rate model estimations (eastern Europe)

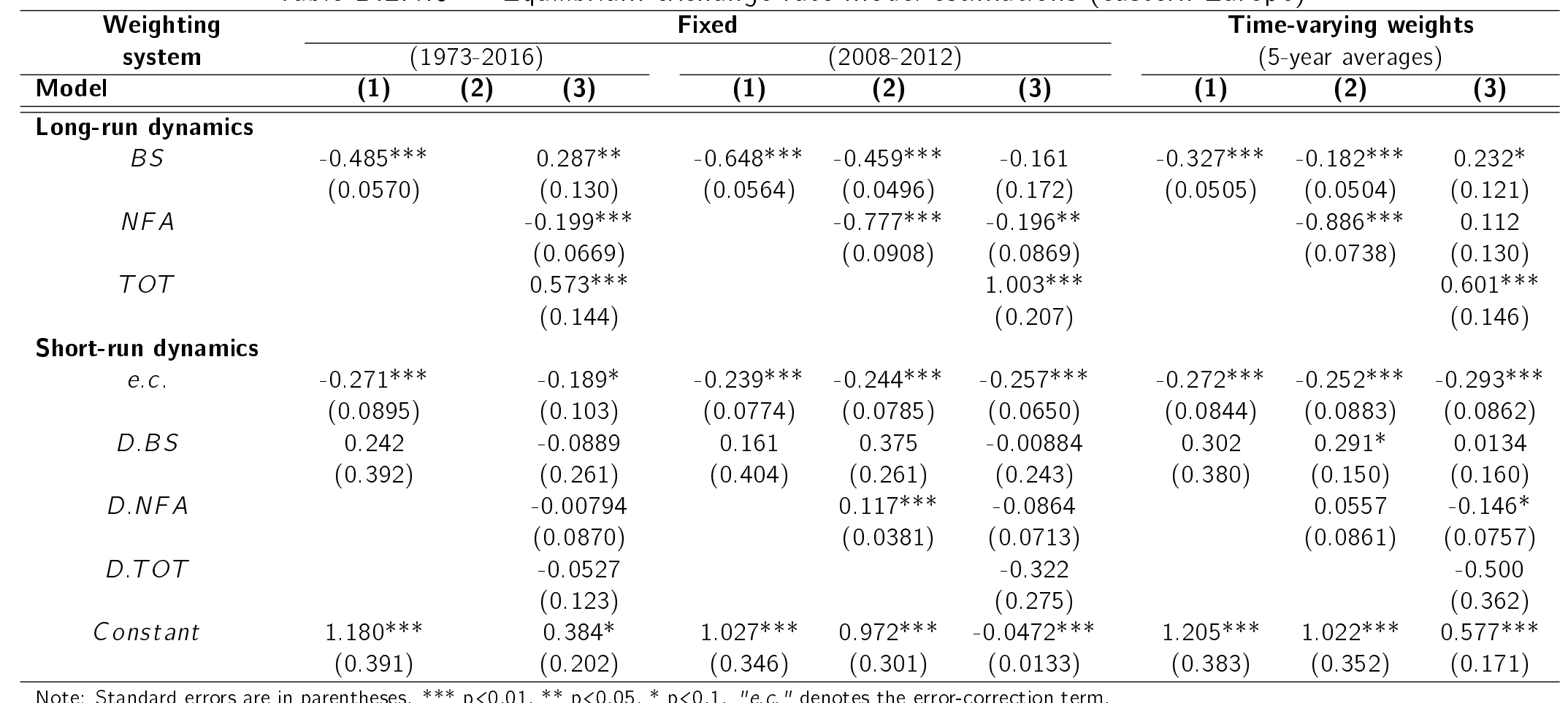


Table B.2.4.7 - Equilibrium exchange rate model estimations (middle Africa)

\begin{tabular}{|c|c|c|c|c|c|c|c|c|c|}
\hline \multirow{3}{*}{$\begin{array}{c}\begin{array}{c}\text { Weighting } \\
\text { system }\end{array} \\
\text { Model }\end{array}$} & \multicolumn{6}{|c|}{ Fixed } & \multirow{2}{*}{\multicolumn{3}{|c|}{$\begin{array}{c}\text { Time-varying weights } \\
\text { (5-year averages) }\end{array}$}} \\
\hline & \multicolumn{3}{|c|}{$(1973-2016)$} & \multicolumn{3}{|c|}{$(2008-2012)$} & & & \\
\hline & (1) & $(2)$ & (3) & (1) & $(2)$ & (3) & (1) & $(2)$ & (3) \\
\hline \multicolumn{10}{|c|}{ Long-run dynamics } \\
\hline$B S$ & $\begin{array}{l}0.239 * * \\
(0.105)\end{array}$ & $\begin{array}{l}-0.392 \\
(0.521)\end{array}$ & $\begin{array}{l}0.273 * * * \\
(0.0583)\end{array}$ & $\begin{array}{l}0.200 * \\
(0.103)\end{array}$ & $\begin{array}{c}0.472 * * * \\
(0.164)\end{array}$ & $\begin{array}{l}0.447^{* * *} \\
(0.0693)\end{array}$ & $\begin{array}{l}0.235^{*} \\
(0.122)\end{array}$ & $\begin{array}{l}-0.0184 \\
(0.0352)\end{array}$ & $\begin{array}{l}0.262 * * * \\
(0.0463)\end{array}$ \\
\hline$N F A$ & & $\begin{array}{l}-1.213 \\
(0.889)\end{array}$ & $\begin{array}{l}0.123 * * * \\
(0.0261)\end{array}$ & & $\begin{array}{c}-0.299 * * \\
(0.123)\end{array}$ & $\begin{array}{c}0.0910 * * * \\
(0.0258)\end{array}$ & & $\begin{array}{l}0.233 * * * \\
(0.0352)\end{array}$ & $\begin{array}{l}0.159 * * * \\
(0.0294)\end{array}$ \\
\hline TOT & & & $\begin{array}{l}-0.0864 \\
(0.0577)\end{array}$ & & & $\begin{array}{l}0.222^{* *} \\
(0.0938)\end{array}$ & & & $\begin{array}{c}-0.292^{* * *} \\
(0.0570)\end{array}$ \\
\hline \multicolumn{10}{|c|}{ Short-run dynamics } \\
\hline e.c. & $\begin{array}{c}-0.250 * * \\
(0.105)\end{array}$ & $\begin{array}{l}-0.115 \\
(0.121)\end{array}$ & $\begin{array}{c}-0.334 * * * \\
(0.0933)\end{array}$ & $\begin{array}{c}-0.261^{* *} \\
(0.106)\end{array}$ & $\begin{array}{l}-0.185 \\
(0.115)\end{array}$ & $\begin{array}{c}-0.266^{* *} \\
(0.110)\end{array}$ & $\begin{array}{c}-0.242^{* *} \\
(0.106)\end{array}$ & $\begin{array}{c}-0.305^{* * *} \\
(0.103)\end{array}$ & $\begin{array}{c}-0.328 * * * \\
(0.103)\end{array}$ \\
\hline$D . B S$ & $\begin{array}{r}-0.0169 \\
(0.240)\end{array}$ & $\begin{array}{l}-0.0778 \\
(0.0956)\end{array}$ & $\begin{array}{c}-0.257^{* *} \\
(0.126)\end{array}$ & $\begin{array}{r}-0.0155 \\
(0.287)\end{array}$ & $\begin{array}{c}-0.244 * * \\
(0.118)\end{array}$ & $\begin{array}{c}-0.386 * * \\
(0.163)\end{array}$ & $\begin{array}{c}-0.00856 \\
(0.227)\end{array}$ & $\begin{array}{l}-0.188 \\
(0.179)\end{array}$ & $\begin{array}{c}-0.121 \\
(0.128)\end{array}$ \\
\hline$D . N F A$ & & $\begin{array}{l}0.121^{* *} \\
(0.0599)\end{array}$ & $\begin{array}{l}-0.0187 \\
(0.0458)\end{array}$ & & $\begin{array}{c}0.100^{*} \\
(0.0580)\end{array}$ & $\begin{array}{c}0.0181 \\
(0.0613)\end{array}$ & & $\begin{array}{l}-0.00655 \\
(0.0491)\end{array}$ & $\begin{array}{l}-0.0292 \\
(0.0487)\end{array}$ \\
\hline D.TOT & & & $\begin{array}{c}0.101 \\
(0.125)\end{array}$ & & & $\begin{array}{c}0.0231 \\
(0.105)\end{array}$ & & & $\begin{array}{c}0.136 \\
(0.124)\end{array}$ \\
\hline Constant & $\begin{array}{l}1.339 * * \\
(0.596)\end{array}$ & $\begin{array}{c}0.348 \\
(0.365)\end{array}$ & $\begin{array}{c}2.015^{* * *} \\
(0.643)\end{array}$ & $\begin{array}{l}1.364^{* *} \\
(0.586)\end{array}$ & $\begin{array}{l}1.073 \\
(0.702)\end{array}$ & $\begin{array}{l}1.345^{* *} \\
(0.642)\end{array}$ & $\begin{array}{l}1.299 * * \\
(0.598)\end{array}$ & $\begin{array}{c}1.493 * * * \\
(0.517)\end{array}$ & $\begin{array}{c}2.263^{* * *} \\
(0.777)\end{array}$ \\
\hline
\end{tabular}

Note: Standard errors are in parentheses. ${ }^{* * *} p<0.01, * * p<0.05, * p<0.1$. "e.c." denotes the error-correction term. 
Table B.2.4.8 - Equilibrium exchange rate model estimations (northern Africa)

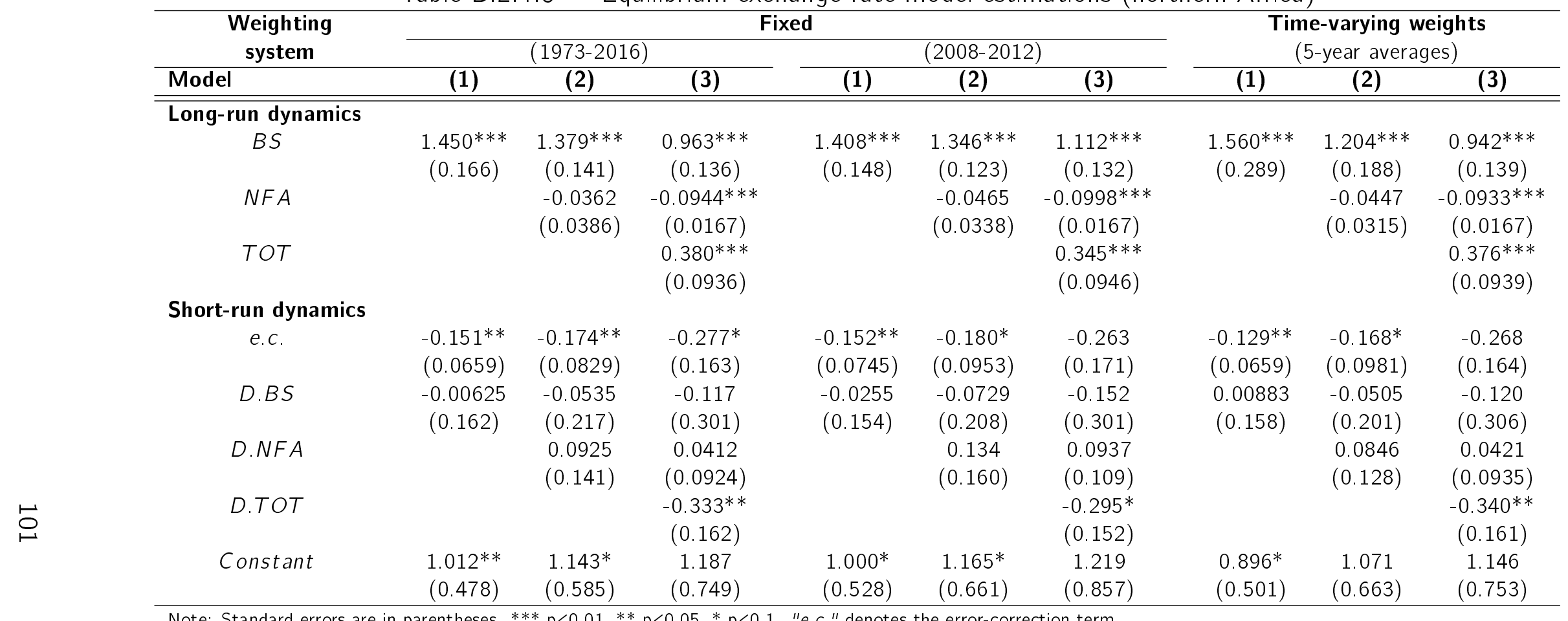


Table B.2.4.9 - Equilibrium exchange rate model estimations (northern Europe)

\begin{tabular}{|c|c|c|c|c|c|c|c|}
\hline \multirow{3}{*}{$\begin{array}{c}\begin{array}{c}\text { Weighting } \\
\text { system }\end{array} \\
\text { Model }\end{array}$} & \multicolumn{4}{|c|}{ Fixed } & \multirow{2}{*}{\multicolumn{3}{|c|}{$\begin{array}{c}\text { Time-varying weights } \\
\text { (5-year averages) }\end{array}$}} \\
\hline & \multicolumn{2}{|c|}{$(1973-2016)$} & \multicolumn{2}{|c|}{$(2008-2012)$} & & & \\
\hline & (1) & (2) $\quad(3)$ & (1) & (2) (3) & (1) & (2) & (3) \\
\hline \multicolumn{8}{|c|}{ Long-run dynamics } \\
\hline$B S$ & $\begin{array}{l}0.827^{* * *} \\
(0.0688)\end{array}$ & $\begin{array}{c}0.0230 \\
(0.0538)\end{array}$ & $\begin{array}{l}0.880^{* * *} \\
(0.0698)\end{array}$ & $\begin{array}{l}0.241^{* * *} \\
(0.0910)\end{array}$ & $\begin{array}{l}0.721^{* * *} \\
(0.0580)\end{array}$ & $\begin{array}{l}0.404^{* * *} \\
(0.0615)\end{array}$ & $\begin{array}{c}0.0791 \\
(0.0725)\end{array}$ \\
\hline NFA & & $\begin{array}{c}0.0161 \\
(0.0130)\end{array}$ & & $\begin{array}{l}0.150 * * \\
(0.0722)\end{array}$ & & $\begin{array}{c}-0.109 * * * \\
(0.0256)\end{array}$ & $\begin{array}{c}0.0128 \\
(0.0125)\end{array}$ \\
\hline TOT & & $\begin{array}{c}1.072 * * * \\
(0.141)\end{array}$ & & $\begin{array}{c}1.184^{* * *} \\
(0.229)\end{array}$ & & & $\begin{array}{c}1.136^{* * *} \\
(0.124)\end{array}$ \\
\hline \multicolumn{8}{|c|}{ Short-run dynamics } \\
\hline e.c. & $\begin{array}{c}-0.333^{* *} \\
(0.131)\end{array}$ & $\begin{array}{c}-0.283^{* * *} \\
(0.0502)\end{array}$ & $\begin{array}{c}-0.299 * * \\
(0.135)\end{array}$ & $\begin{array}{c}-0.178^{* * *} \\
(0.0515)\end{array}$ & $\begin{array}{c}-0.369 * * * \\
(0.127)\end{array}$ & $\begin{array}{c}-0.271^{* * *} \\
(0.0879)\end{array}$ & $\begin{array}{c}-0.285^{* * *} \\
(0.0579)\end{array}$ \\
\hline D.BS & $\begin{array}{c}-0.272^{* *} \\
(0.122)\end{array}$ & $\begin{array}{l}-0.122 * \\
(0.0658)\end{array}$ & $\begin{array}{c}-0.288^{* *} \\
(0.133)\end{array}$ & $\begin{array}{l}-0.152 \\
(0.108)\end{array}$ & $\begin{array}{r}-0.153 * * \\
(0.0680)\end{array}$ & $\begin{array}{l}-0.0824 \\
(0.0703)\end{array}$ & $\begin{array}{l}-0.131^{* *} \\
(0.0543)\end{array}$ \\
\hline D.NFA & & $\begin{array}{l}-0.0104 \\
(0.0373)\end{array}$ & & $\begin{array}{l}-0.0137 \\
(0.0362)\end{array}$ & & $\begin{array}{c}0.0166 \\
(0.0532)\end{array}$ & $\begin{array}{l}-0.0318 \\
(0.0214)\end{array}$ \\
\hline D.TOT & & $\begin{array}{l}0.191^{*} \\
(0.116)\end{array}$ & & $\begin{array}{l}0.234^{*} \\
(0.139)\end{array}$ & & & $\begin{array}{l}0.131^{* *} \\
(0.0575)\end{array}$ \\
\hline Constant & $\begin{array}{l}1.608^{* *} \\
(0.644)\end{array}$ & $\begin{array}{c}-0.0771^{* * *} \\
(0.0147)\end{array}$ & $\begin{array}{l}1.442 * * \\
(0.656)\end{array}$ & $\begin{array}{c}-0.128 * * * \\
(0.0337)\end{array}$ & $\begin{array}{c}1.770^{* * *} \\
(0.616)\end{array}$ & $\begin{array}{c}1.258^{* * *} \\
(0.410)\end{array}$ & $\begin{array}{c}-0.162 * * * \\
(0.0339)\end{array}$ \\
\hline
\end{tabular}

Note: Standard errors are in parentheses. ${ }^{* * *} \mathrm{p}<0.01,{ }^{* *} \mathrm{p}<0.05, * \mathrm{p}<0.1$. "e.c." denotes the error-correction term. 
Table B.2.4.10 - Equilibrium exchange rate model estimations (south America)

\begin{tabular}{|c|c|c|c|c|c|c|c|c|c|}
\hline \multirow{3}{*}{$\begin{array}{ll}\begin{array}{c}\text { Weighting } \\
\text { system }\end{array} \\
\text { Model } \\
\end{array}$} & \multicolumn{6}{|c|}{ Fixed } & \multirow{2}{*}{\multicolumn{3}{|c|}{$\begin{array}{c}\text { Time-varying weights } \\
\text { (5-year averages) }\end{array}$}} \\
\hline & \multicolumn{3}{|c|}{$(1973-2016)$} & \multicolumn{3}{|c|}{$(2008-2012)$} & & & \\
\hline & (1) & $(2)$ & (3) & (1) & $(2)$ & (3) & (1) & $(2)$ & (3) \\
\hline \multicolumn{10}{|c|}{ Long-run dynamics } \\
\hline$B S$ & $\begin{array}{c}0.783 * * * \\
(0.167)\end{array}$ & $\begin{array}{l}0.539 * * \\
(0.211)\end{array}$ & $\begin{array}{c}-0.598 * * * \\
(0.221)\end{array}$ & $\begin{array}{c}0.668 * * * \\
(0.135)\end{array}$ & $\begin{array}{l}-0.0319 \\
(0.154)\end{array}$ & $\begin{array}{c}0.0466 \\
(0.0921)\end{array}$ & $\begin{array}{c}0.160 \\
(0.145)\end{array}$ & $\begin{array}{c}0.151 \\
(0.279)\end{array}$ & $\begin{array}{c}0.561^{* * *} \\
(0.197)\end{array}$ \\
\hline$N F A$ & & $\begin{array}{l}0.226 * * \\
(0.110)\end{array}$ & $\begin{array}{c}0.0840 \\
(0.0840)\end{array}$ & & $\begin{array}{c}2.064^{* * *} \\
(0.399)\end{array}$ & $\begin{array}{c}1.548 * * * \\
(0.222)\end{array}$ & & $\begin{array}{c}2.565 * * * \\
(0.533)\end{array}$ & $\begin{array}{c}0.178 \\
(0.111)\end{array}$ \\
\hline TOT & & & $\begin{array}{c}0.662^{* * *} \\
(0.154)\end{array}$ & & & $\begin{array}{c}0.598 * * * \\
(0.101)\end{array}$ & & & $\begin{array}{l}0.0802 \\
(0.147)\end{array}$ \\
\hline \multicolumn{10}{|c|}{ Short-run dynamics } \\
\hline e.c. & $\begin{array}{l}-0.120 * * \\
(0.0604)\end{array}$ & $\begin{array}{l}-0.0919 \\
(0.0567)\end{array}$ & $\begin{array}{c}-0.117^{* * * *} \\
(0.0334)\end{array}$ & $\begin{array}{c}-0.141^{* *} \\
(0.0590)\end{array}$ & $\begin{array}{c}-0.102 * * * \\
(0.0301)\end{array}$ & $\begin{array}{c}-0.101^{* *} \\
(0.0430)\end{array}$ & $\begin{array}{l}-0.0875 \\
(0.0644)\end{array}$ & $\begin{array}{c}-0.0864 * * * \\
(0.0238)\end{array}$ & $\begin{array}{c}-0.176 * * * \\
(0.0537)\end{array}$ \\
\hline$D . B S$ & $\begin{array}{c}0.430 * * * \\
(0.154)\end{array}$ & $\begin{array}{c}0.433^{* * * *} \\
(0.135)\end{array}$ & $\begin{array}{c}0.554^{* * *} \\
(0.146)\end{array}$ & $\begin{array}{c}0.335^{* *} \\
(0.139)\end{array}$ & $\begin{array}{c}0.333 * * \\
(0.147)\end{array}$ & $\begin{array}{l}0.320 * * \\
(0.153)\end{array}$ & $\begin{array}{c}0.420 * * * \\
(0.141)\end{array}$ & $\begin{array}{c}0.325^{* * *} \\
(0.123)\end{array}$ & $\begin{array}{c}0.367^{* * *} \\
(0.135)\end{array}$ \\
\hline D.NFA & & $\begin{array}{l}-0.270 \\
(0.287)\end{array}$ & $\begin{array}{l}-0.0129 \\
(0.0765)\end{array}$ & & $\begin{array}{l}-0.405 \\
(0.325)\end{array}$ & $\begin{array}{l}-0.107 \\
(0.123)\end{array}$ & & $\begin{array}{l}-0.454 \\
(0.341)\end{array}$ & $\begin{array}{c}0.0221 \\
(0.0693)\end{array}$ \\
\hline D.TOT & & & $\begin{array}{l}-0.185^{* *} \\
(0.0743)\end{array}$ & & & $\begin{array}{l}-0.149 * * \\
(0.0724)\end{array}$ & & & $\begin{array}{l}-0.135 * * \\
(0.0611)\end{array}$ \\
\hline Constant & $\begin{array}{l}0.694 * * \\
(0.311)\end{array}$ & $\begin{array}{l}0.521^{*} \\
(0.267)\end{array}$ & $\begin{array}{l}0.109 * * * \\
(0.0402)\end{array}$ & $\begin{array}{c}0.769 * * * \\
(0.286)\end{array}$ & $\begin{array}{c}0.504^{* * * *} \\
(0.146)\end{array}$ & $\begin{array}{l}0.228 * * \\
(0.0932)\end{array}$ & $\begin{array}{c}0.452 \\
(0.287)\end{array}$ & $\begin{array}{c}0.443 * * * \\
(0.116)\end{array}$ & $\begin{array}{c}0.826 * * * \\
(0.255)\end{array}$ \\
\hline
\end{tabular}


Table B.2.4.11 - Equilibrium exchange rate model estimations (south eastern Asia)

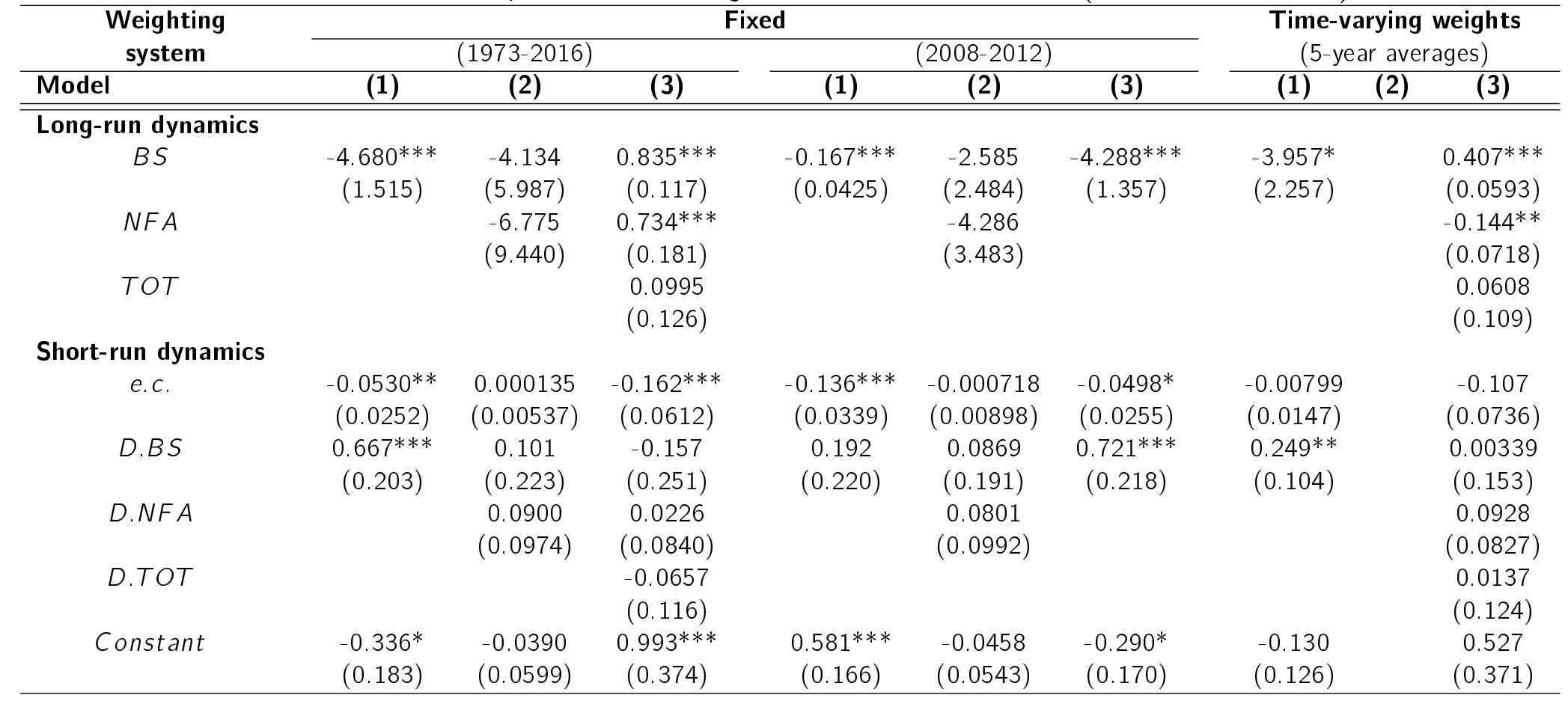

Note: Standard errors are in parentheses. ${ }^{* * *} \mathrm{p}<0.01,{ }^{* *} \mathrm{p}<0.05,{ }^{*} \mathrm{p}<0.1$. "e.c." denotes the error-correction term. 
Table B.2.4.12 - Equilibrium exchange rate model estimations (southern Africa)

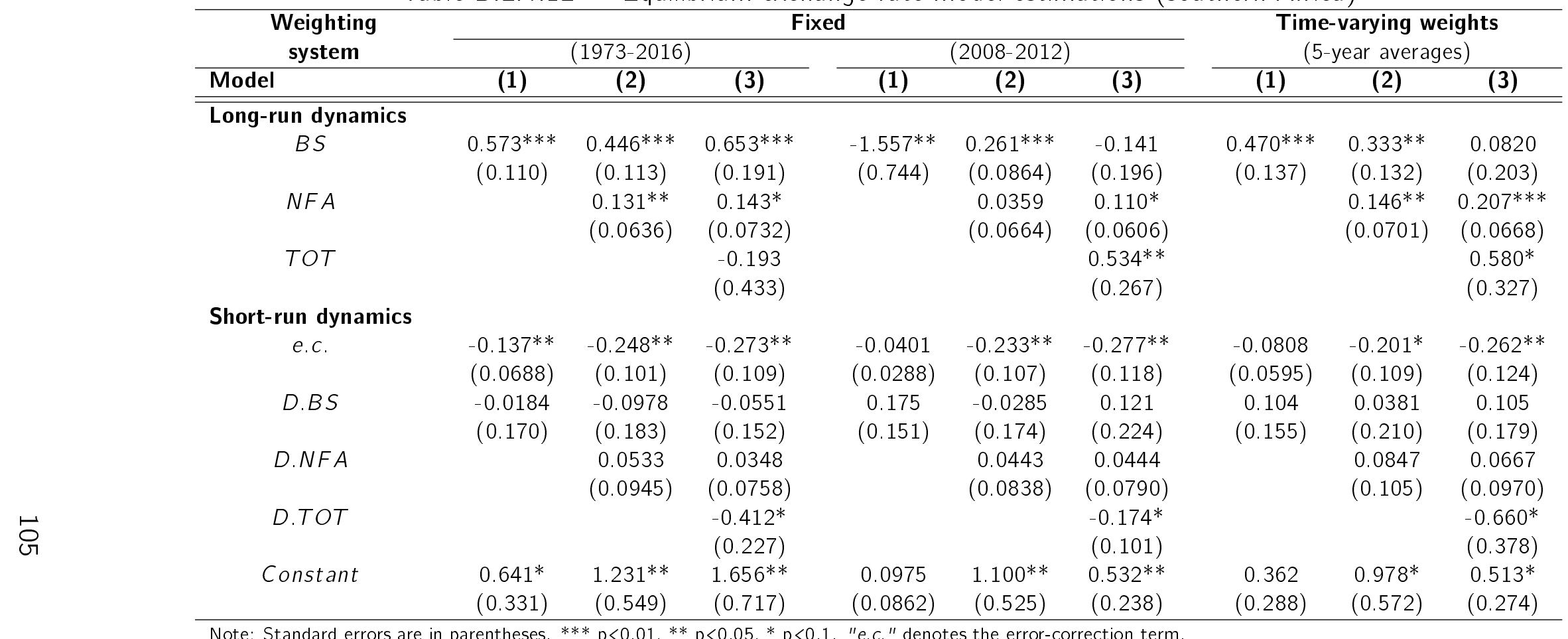


Table B.2.4.13 - Equilibrium exchange rate model estimations (southern Asia)

\begin{tabular}{|c|c|c|c|c|c|c|c|c|c|}
\hline \multirow{2}{*}{$\begin{array}{l}\begin{array}{c}\text { Weighting } \\
\text { system }\end{array} \\
\text { Model }\end{array}$} & \multicolumn{6}{|c|}{ Fixed } & \multirow{2}{*}{\multicolumn{3}{|c|}{$\begin{array}{c}\text { Time-varying weights } \\
\text { (5-year averages) }\end{array}$}} \\
\hline & \multicolumn{3}{|c|}{$(1973-2016)$} & \multicolumn{3}{|c|}{$(2008-2012)$} & & & 5) \\
\hline \multicolumn{10}{|c|}{ Long-run dynamics } \\
\hline$B S$ & $\begin{array}{l}0.264^{* *} \\
(0.103)\end{array}$ & $\begin{array}{c}0.140 \\
(0.117)\end{array}$ & $\begin{array}{c}0.215 \\
(0.160)\end{array}$ & $\begin{array}{l}0.229 * * \\
(0.100)\end{array}$ & $\begin{array}{c}0.0290 \\
(0.0838)\end{array}$ & $\begin{array}{c}0.216 \\
(0.174)\end{array}$ & $\begin{array}{c}0.390^{* * *} \\
(0.111)\end{array}$ & $\begin{array}{c}0.462^{* * *} \\
(0.128)\end{array}$ & $\begin{array}{c}0.241 \\
(0.215)\end{array}$ \\
\hline$N F A$ & & $\begin{array}{l}0.0326^{*} \\
(0.0175)\end{array}$ & $\begin{array}{l}-0.0851^{*} \\
(0.0466)\end{array}$ & & $\begin{array}{c}0.0525^{* * *} \\
(0.0136)\end{array}$ & $\begin{array}{l}-0.0540 \\
(0.0391)\end{array}$ & & $\begin{array}{c}0.649 * * * \\
(0.229)\end{array}$ & $\begin{array}{c}0.0383 \\
(0.0271)\end{array}$ \\
\hline TOT & & & $\begin{array}{c}1.121^{* * *} \\
(0.260)\end{array}$ & & & $\begin{array}{c}1.040 * * * \\
(0.244)\end{array}$ & & & $\begin{array}{l}-0.313 \\
(0.320)\end{array}$ \\
\hline \multicolumn{10}{|c|}{ Short-run dynamics } \\
\hline e.c. & $\begin{array}{c}-0.292 * * * \\
(0.111)\end{array}$ & $\begin{array}{c}-0.325^{* *} \\
(0.145)\end{array}$ & $\begin{array}{l}-0.158^{*} \\
(0.0838)\end{array}$ & $\begin{array}{l}-0.284 * * * \\
(0.107)\end{array}$ & $\begin{array}{c}-0.363 * * \\
(0.154)\end{array}$ & $\begin{array}{l}-0.190^{*} \\
(0.0994)\end{array}$ & $\begin{array}{c}-0.291^{* * *} \\
(0.111)\end{array}$ & $\begin{array}{l}-0.180 * * \\
(0.0797)\end{array}$ & $\begin{array}{c}-0.256^{* *} \\
(0.119)\end{array}$ \\
\hline$D . B S$ & $\begin{array}{r}-0.0403 \\
(0.124)\end{array}$ & $\begin{array}{l}-0.0705 \\
(0.138)\end{array}$ & $\begin{array}{l}0.0284 \\
(0.119)\end{array}$ & $\begin{array}{l}0.00498 \\
(0.119)\end{array}$ & $\begin{array}{r}-0.0358 \\
(0.141)\end{array}$ & $\begin{array}{c}0.184 \\
(0.154)\end{array}$ & $\begin{array}{l}-0.0341 \\
(0.0990)\end{array}$ & $\begin{array}{r}-0.0149 \\
(0.119)\end{array}$ & $\begin{array}{r}-0.0196 \\
(0.152)\end{array}$ \\
\hline$D . N F A$ & & $\begin{array}{l}0.311^{* * *} \\
(0.0681)\end{array}$ & $\begin{array}{c}0.182 \\
(0.153)\end{array}$ & & $\begin{array}{l}0.317 * * * \\
(0.0717)\end{array}$ & $\begin{array}{c}0.214 \\
(0.148)\end{array}$ & & $\begin{array}{l}0.184^{* *} \\
(0.0859)\end{array}$ & $\begin{array}{c}0.163 \\
(0.146)\end{array}$ \\
\hline D.TOT & & & $\begin{array}{l}0.00937 \\
(0.0976)\end{array}$ & & & $\begin{array}{l}0.0213 \\
(0.104)\end{array}$ & & & $\begin{array}{c}0.137 \\
(0.109)\end{array}$ \\
\hline Constant & $\begin{array}{c}1.442^{* * *} \\
(0.539)\end{array}$ & $\begin{array}{l}1.554 * * \\
(0.690)\end{array}$ & $\begin{array}{c}-0.0532 * * \\
(0.0268)\end{array}$ & $\begin{array}{c}1.384 * * * \\
(0.515)\end{array}$ & $\begin{array}{l}1.681^{* *} \\
(0.710)\end{array}$ & $\begin{array}{l}0.00530 \\
(0.0186)\end{array}$ & $\begin{array}{c}1.486^{* * *} \\
(0.560)\end{array}$ & $\begin{array}{c}0.969 * * \\
(0.420)\end{array}$ & $\begin{array}{l}1.609 * * \\
(0.757)\end{array}$ \\
\hline
\end{tabular}

Note: Standard errors are in parentheses. ${ }^{* * *} \mathrm{p}<0.01, * * \mathrm{p}<0.05, * \mathrm{p}<0.1$. "e.c." denotes the error-correction term. 
Table B.2.4.14 - Equilibrium exchange rate model estimations (southern Europe)

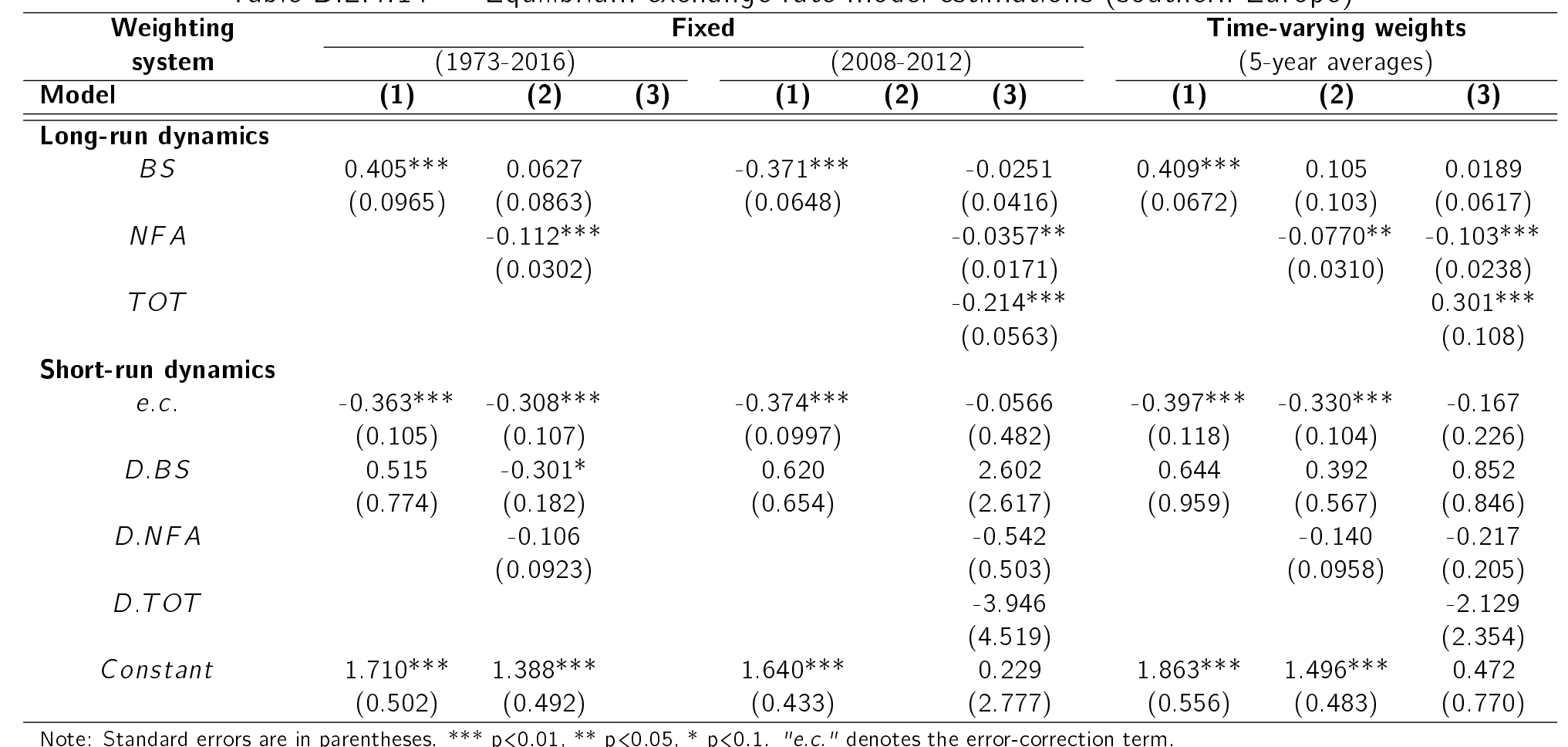


Table B.2.4.15 - Equilibrium exchange rate model estimations (western Africa)

\begin{tabular}{|c|c|c|c|c|c|c|c|c|c|}
\hline \multirow{2}{*}{$\begin{array}{c}\begin{array}{c}\text { Weighting } \\
\text { system }\end{array} \\
\text { Model }\end{array}$} & \multicolumn{6}{|c|}{ Fixed } & \multirow{2}{*}{\multicolumn{3}{|c|}{$\begin{array}{c}\text { Time-varying weights } \\
\text { (5-year averages) }\end{array}$}} \\
\hline & \multicolumn{3}{|c|}{$(1973-2016)$} & \multicolumn{3}{|c|}{$(2008-2012)$} & & & \\
\hline \multicolumn{10}{|c|}{ Long-run dynamics } \\
\hline$B S$ & $\begin{array}{c}-0.245^{* * *} \\
(0.0593)\end{array}$ & $\begin{array}{c}-0.662^{* * *} \\
(0.0961)\end{array}$ & $\begin{array}{c}-0.358^{* * *} \\
(0.0896)\end{array}$ & $\begin{array}{c}0.235^{* * *} * \\
(0.0731)\end{array}$ & $\begin{array}{l}0.234 * * * \\
(0.0770)\end{array}$ & $\begin{array}{c}0.0323 \\
(0.0694)\end{array}$ & $\begin{array}{c}-0.174 * * * \\
(0.0626)\end{array}$ & $\begin{array}{c}-0.672 * * * \\
(0.0974)\end{array}$ & $\begin{array}{c}-0.514^{* * *} \\
(0.0604)\end{array}$ \\
\hline$N F A$ & & $\begin{array}{c}0.0477 * * * \\
(0.0115)\end{array}$ & $\begin{array}{l}0.00761 \\
(0.0193)\end{array}$ & & $\begin{array}{c}0.350 * * * \\
(0.104)\end{array}$ & $\begin{array}{l}0.00909 \\
(0.0289)\end{array}$ & & $\begin{array}{c}0.0488 * * * \\
(0.0115)\end{array}$ & $\begin{array}{l}0.0259 * \\
(0.0137)\end{array}$ \\
\hline TOT & & & $\begin{array}{c}1.559 * * * \\
(0.285)\end{array}$ & & & $\begin{array}{c}0.404 * * * \\
(0.108)\end{array}$ & & & $\begin{array}{c}0.929 * * * \\
(0.136)\end{array}$ \\
\hline \multicolumn{10}{|c|}{ Short-run dynamics } \\
\hline e.c. & $\begin{array}{c}-0.188 * * * \\
(0.0445)\end{array}$ & $\begin{array}{c}-0.122 * * \\
(0.0530)\end{array}$ & $\begin{array}{c}-0.0886 * * * \\
(0.0268)\end{array}$ & $\begin{array}{c}-0.159 * * * \\
(0.0226)\end{array}$ & $\begin{array}{c}-0.132 * * * \\
(0.0245)\end{array}$ & $\begin{array}{c}-0.204 * * * \\
(0.0432)\end{array}$ & $\begin{array}{c}-0.196 * * * \\
(0.0436)\end{array}$ & $\begin{array}{c}-0.126 * * \\
(0.0544)\end{array}$ & $\begin{array}{c}-0.111^{* * *} \\
(0.0339)\end{array}$ \\
\hline$D . B S$ & $\begin{array}{l}-0.311 \\
(0.250)\end{array}$ & $\begin{array}{l}-0.330 \\
(0.246)\end{array}$ & $\begin{array}{c}-0.454 \\
(0.293)\end{array}$ & $\begin{array}{c}-0.239 * \\
(0.140)\end{array}$ & $\begin{array}{c}-0.239 * \\
(0.138)\end{array}$ & $\begin{array}{c}-0.322 * * \\
(0.163)\end{array}$ & $\begin{array}{l}-0.0628 \\
(0.0920)\end{array}$ & $\begin{array}{l}-0.0637 \\
(0.0819)\end{array}$ & $\begin{array}{l}-0.131 \\
(0.127)\end{array}$ \\
\hline D.NFA & & $\begin{array}{l}0.222 * * * \\
(0.0651)\end{array}$ & $\begin{array}{l}0.264 * * * \\
(0.0768)\end{array}$ & & $\begin{array}{l}0.178 * * * \\
(0.0672)\end{array}$ & $\begin{array}{c}0.249 * * * \\
(0.0707)\end{array}$ & & $\begin{array}{l}0.205 * * * \\
(0.0586)\end{array}$ & $\begin{array}{l}0.207 * * * \\
(0.0546)\end{array}$ \\
\hline D.TOT & & & $\begin{array}{l}-0.180^{*} \\
(0.0983)\end{array}$ & & & $\begin{array}{c}-0.110 \\
(0.0688)\end{array}$ & & & $\begin{array}{c}-0.205 \\
(0.152)\end{array}$ \\
\hline Constant & $\begin{array}{c}0.735 * * * \\
(0.149)\end{array}$ & $\begin{array}{c}0.355^{* * * *} \\
(0.126)\end{array}$ & $\begin{array}{c}-0.279 * * * \\
(0.0864)\end{array}$ & $\begin{array}{c}0.805^{* * *} \\
(0.115)\end{array}$ & $\begin{array}{c}0.706^{* * *} \\
(0.129)\end{array}$ & $\begin{array}{c}0.584 * * * \\
(0.122)\end{array}$ & $\begin{array}{c}0.804 * * * \\
(0.157)\end{array}$ & $\begin{array}{c}0.365 * * * \\
(0.133)\end{array}$ & $\begin{array}{c}-0.0817^{* * *} \\
(0.0282)\end{array}$ \\
\hline
\end{tabular}

Note: Standard errors are in parentheses. ${ }^{* * *} \mathrm{p}<0.01,{ }^{* *} \mathrm{p}<0.05,{ }^{*} \mathrm{p}<0.1$. "e.c. " denotes the error-correction term. 
Table B.2.4.16 - Equilibrium exchange rate model estimations (Western Asia)

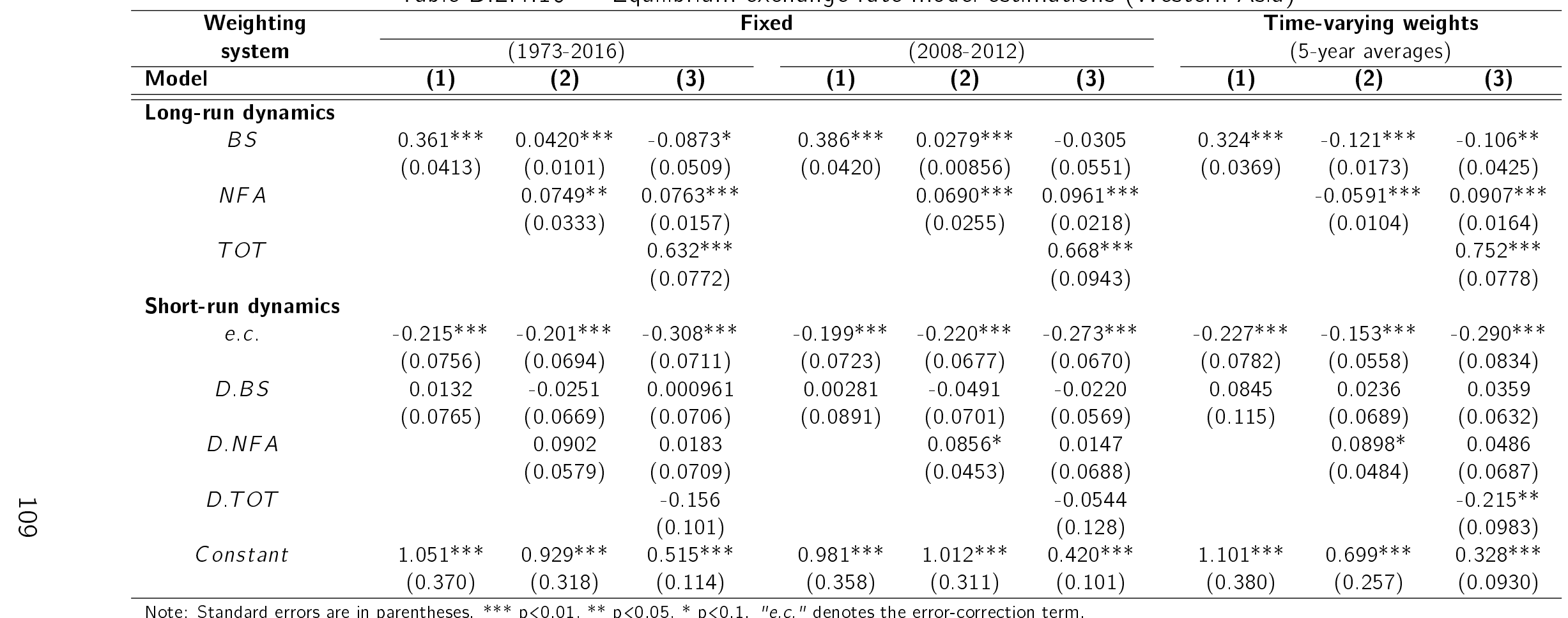


Table B.2.4.17 - Equilibrium exchange rate model estimations (western Europe)

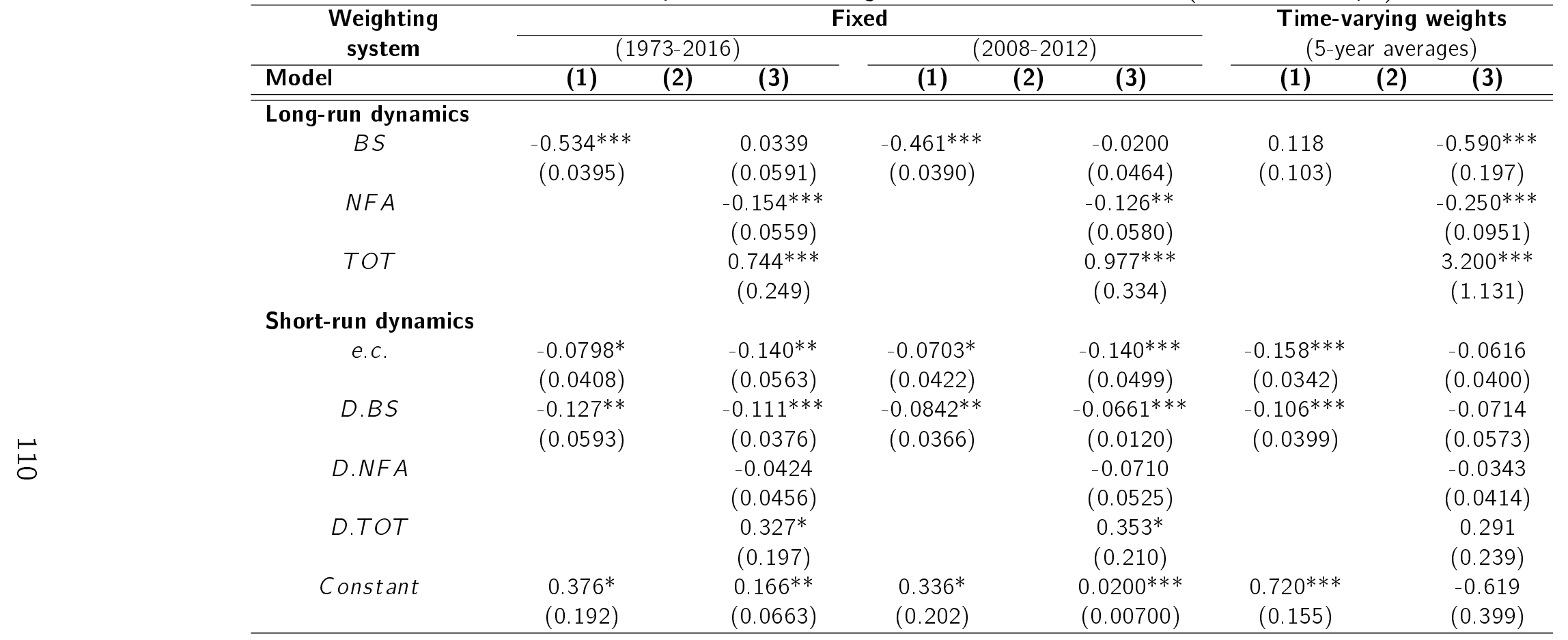

Note: Standard errors are in parentheses. ${ }^{* * *} \mathrm{p}<0.01,{ }^{* *} \mathrm{p}<0.05, * \mathrm{p}<0.1$. "e.c." denotes the error-correction term. 


\section{Figures}
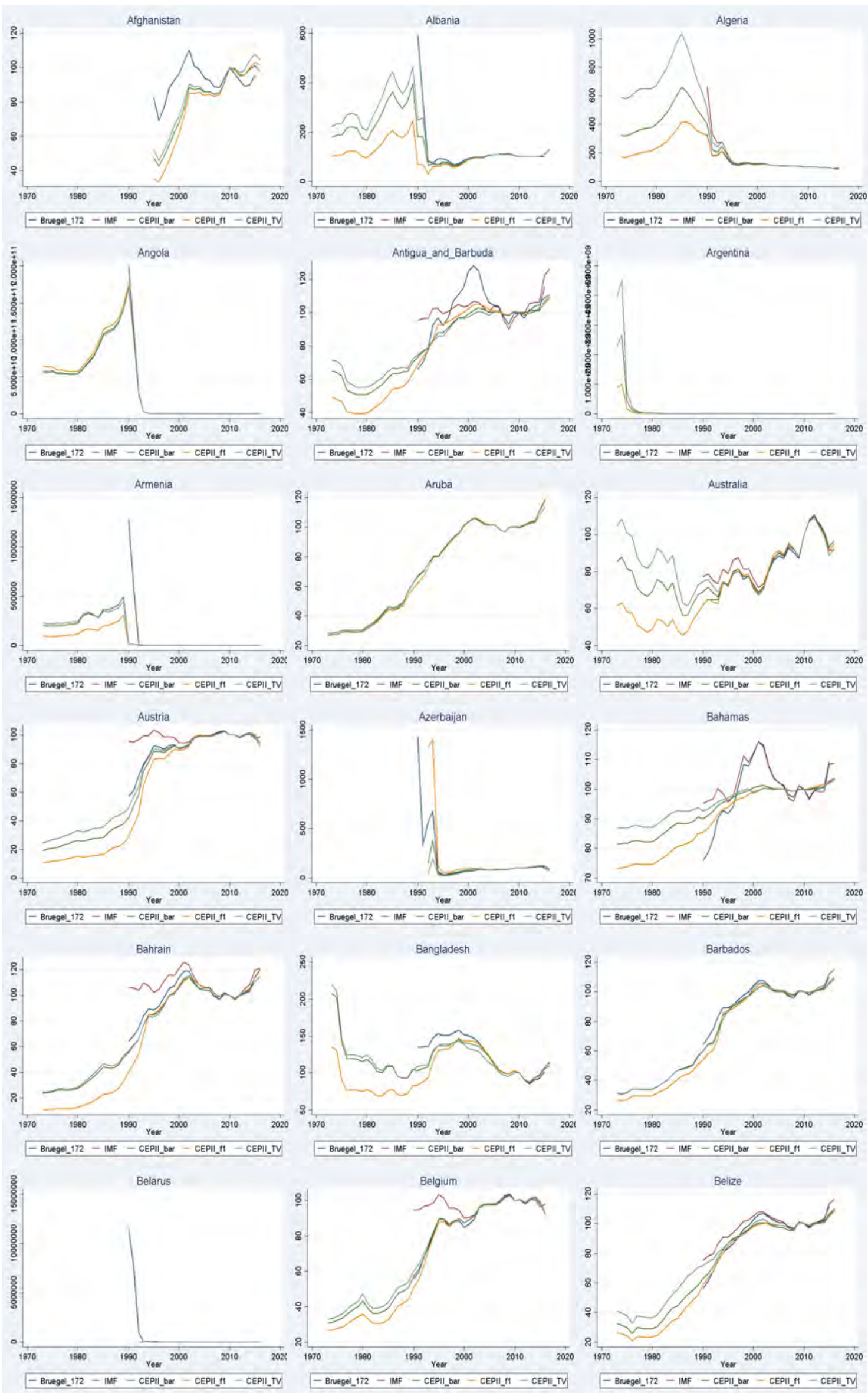

Figure C. 1 - Nominal effective exchange rates $(2010=100)$

Note: an increase corresponds to an appreciation. "f1": fixed weights 2008-2012; "bar": fixed weights 1973-2016; "TV": time-varying weights (5 years averages) 

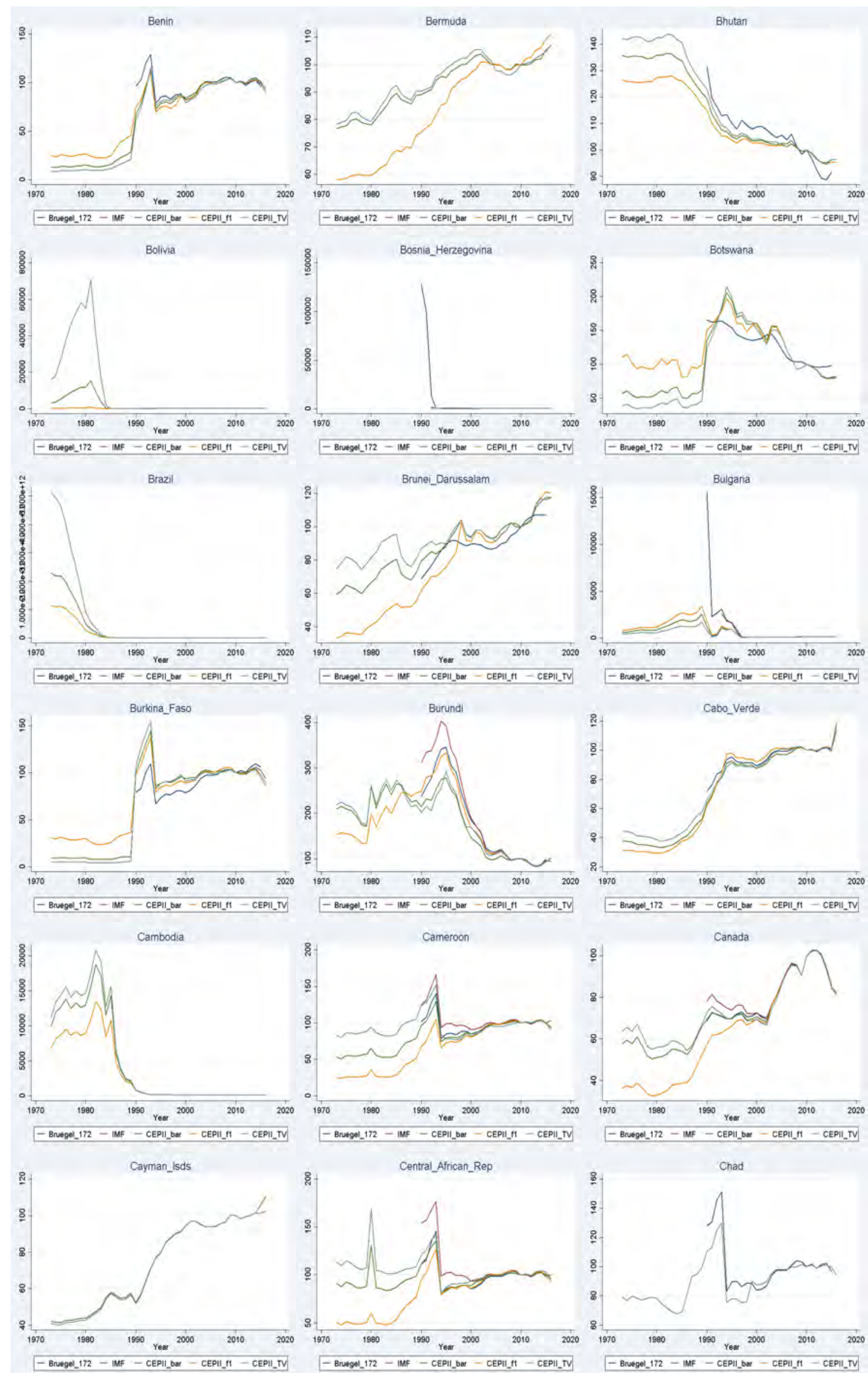

Figure C.1 - (Continued from previous page)

Note: an increase corresponds to an appreciation. "f1": fixed weights 2008-2012; "bar": fixed weights 1973-2016;

"TV": time-varying weights (5 years averages) 

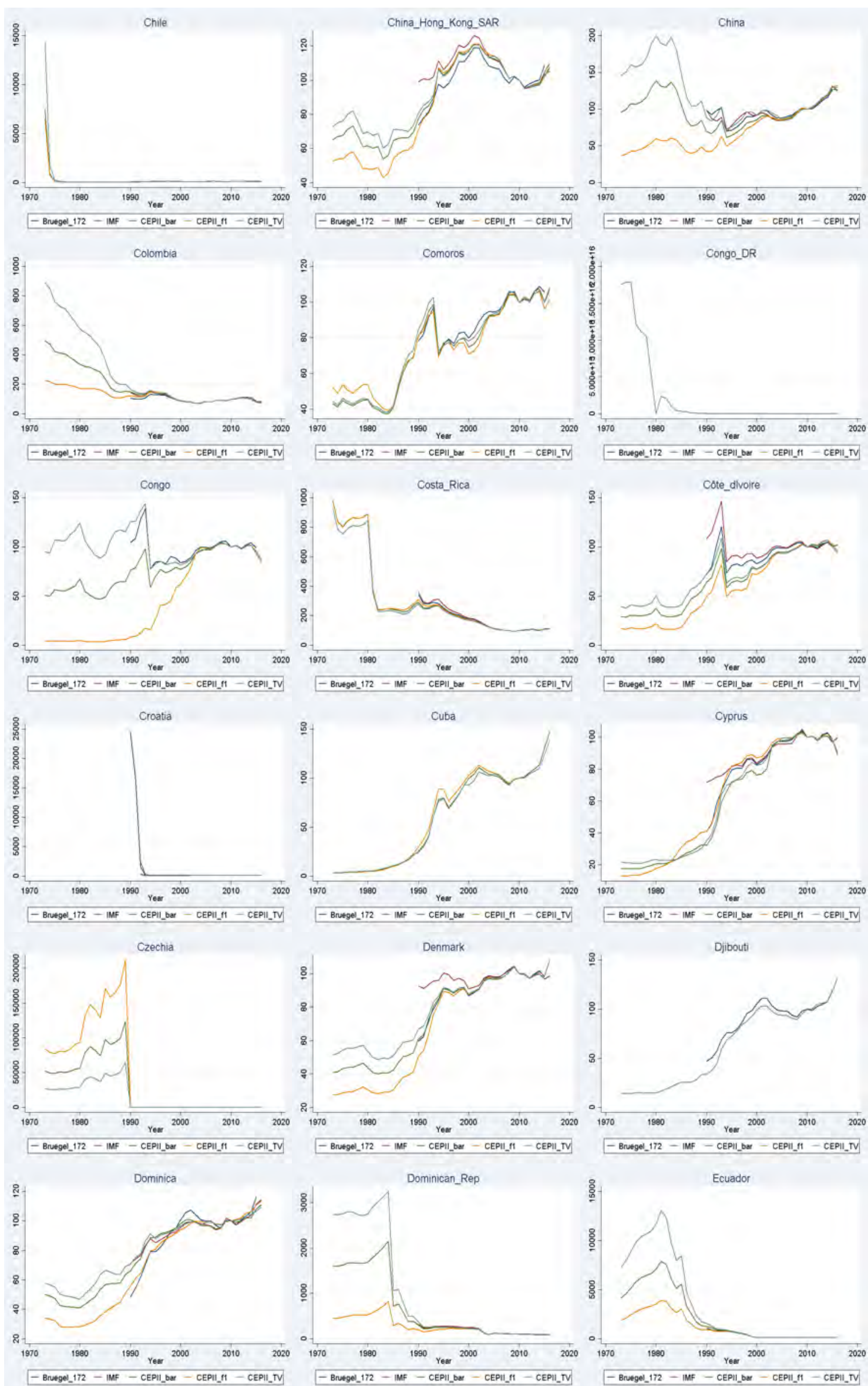

Figure C.1 - (Continued from previous page)

Note: an increase corresponds to an appreciation. "f1": fixed weights 2008-2012; "bar": fixed weights 1973-2016; "TV": time-varying weights (5 years averages) 

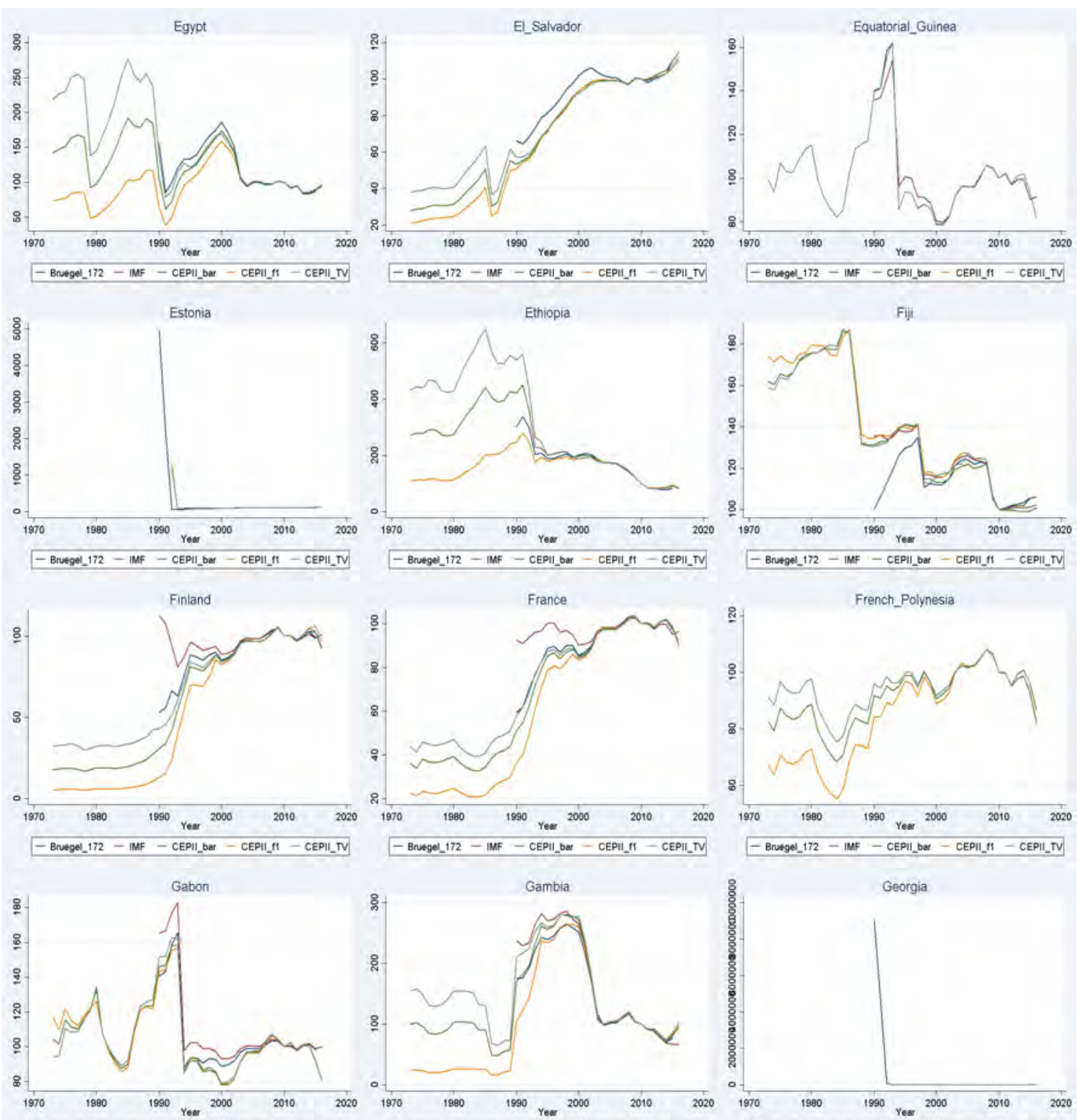

- Brutgel_172 - IMF - CEPII_bat - CEPII_H - CEPII_TV
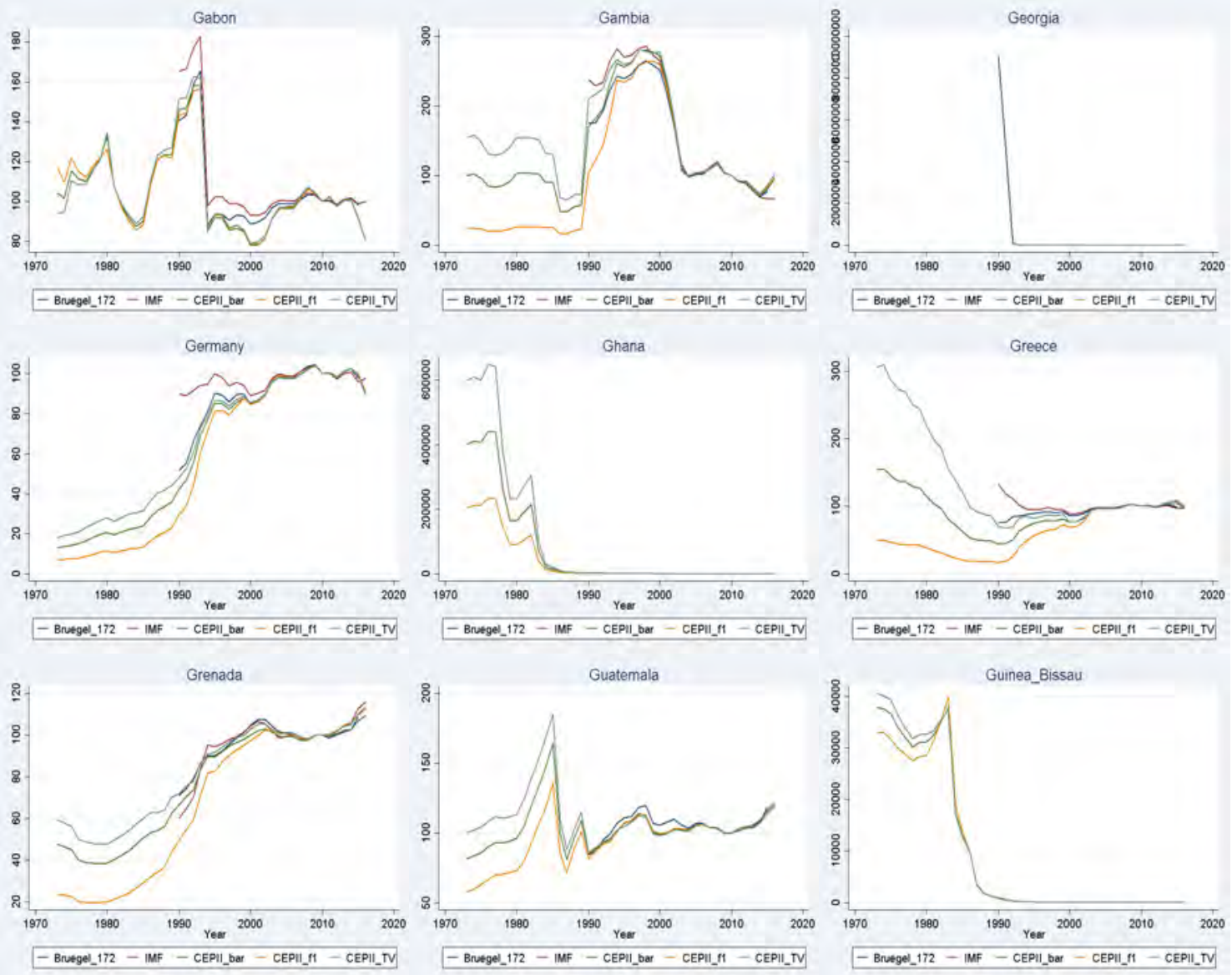

Figure C.1 - (Continued from previous page)

Note: an increase corresponds to an appreciation. "f1": fixed weights 2008-2012; "bar": fixed weights 1973-2016;

"TV": time-varying weights (5 years averages) 

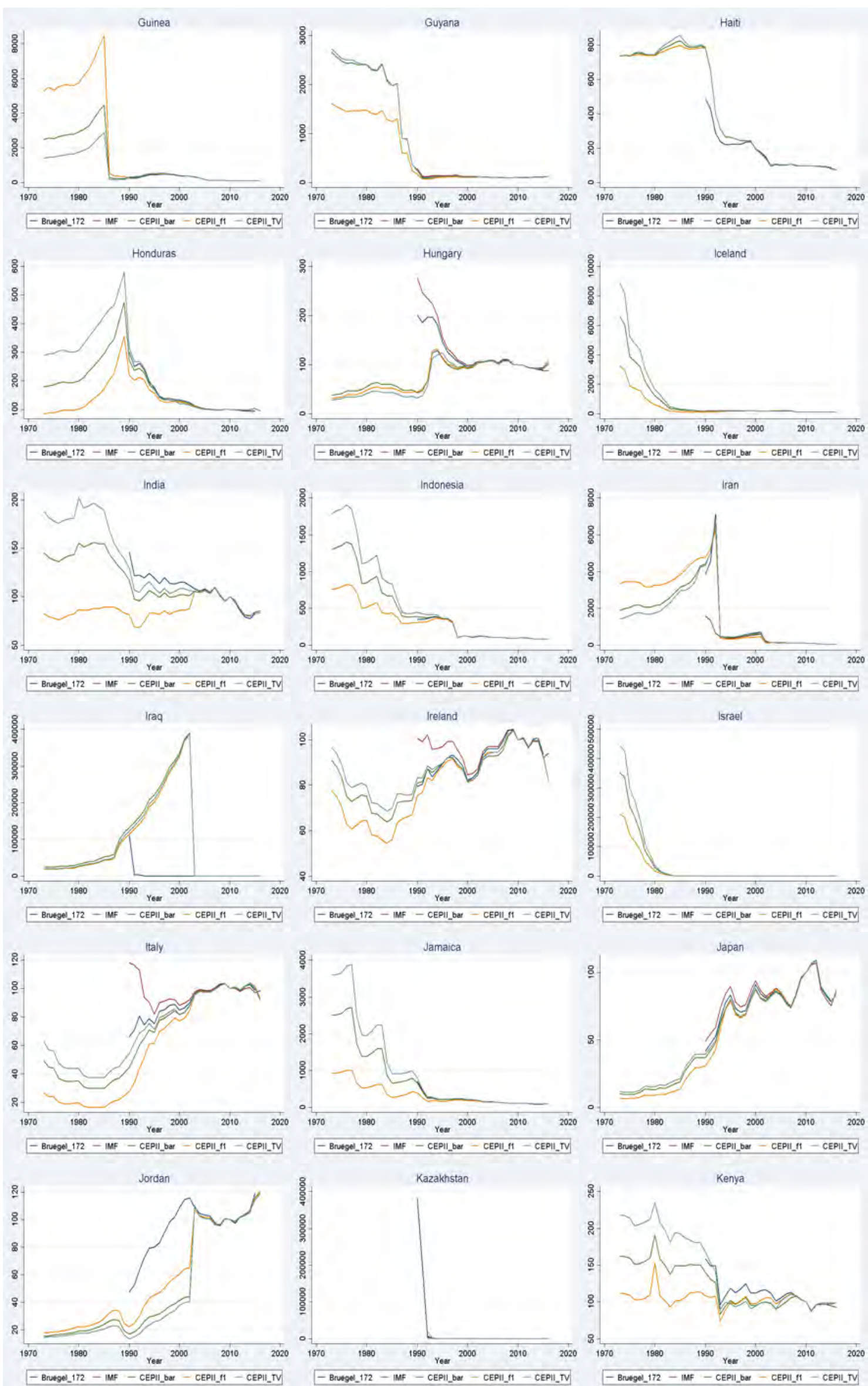

Figure C.1 - (Continued from previous page)

Note: an increase corresponds to an appreciation. "f1": fixed weights 2008-2012; "bar": fixed weights 1973-2016;

"TV": time-varying weights (5 years averages) 

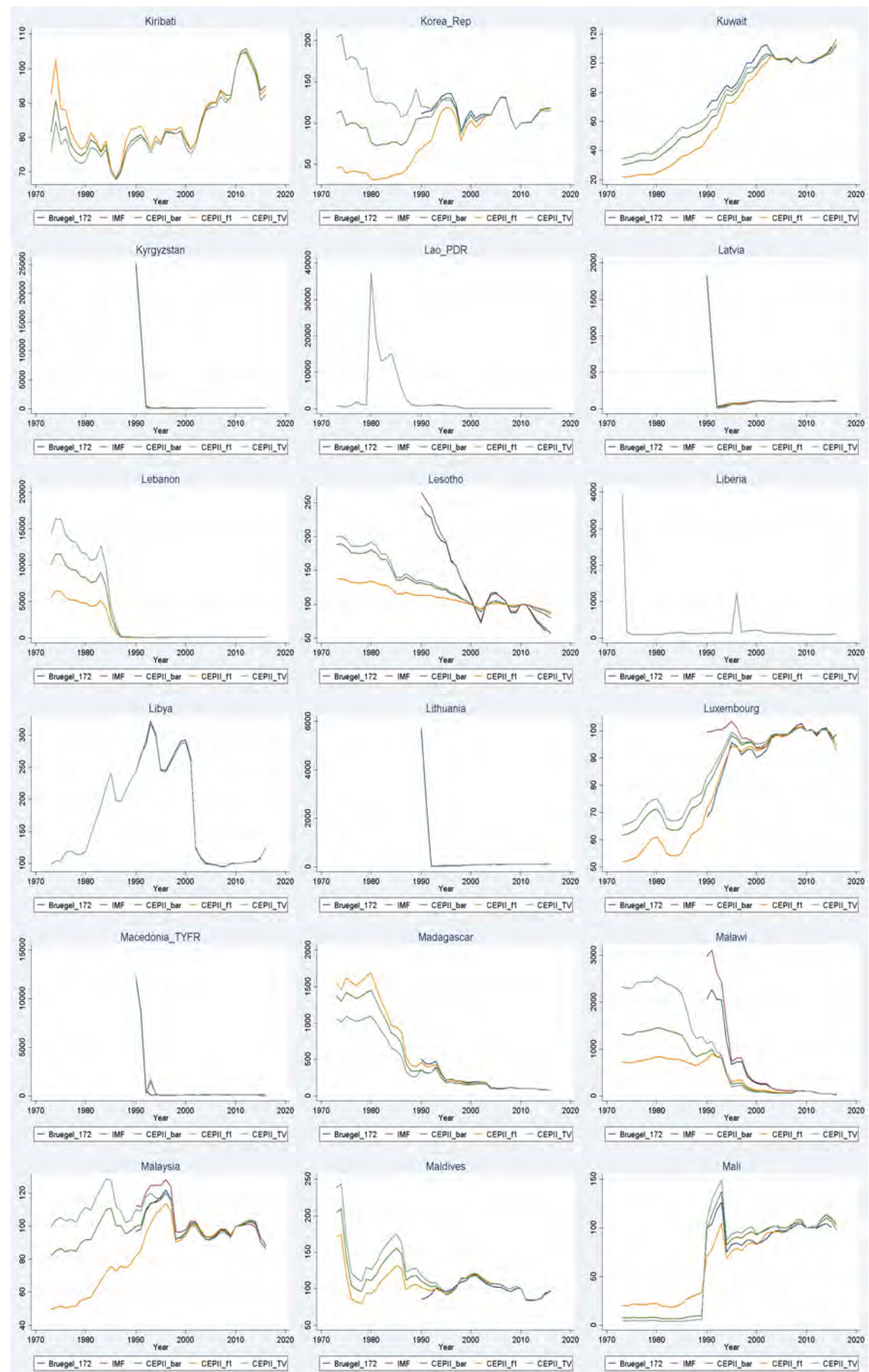

Figure C.1 - (Continued from previous page)

Note: an increase corresponds to an appreciation. "f1": fixed weights 2008-2012; "bar": fixed weights 1973-2016;

"TV": time-varying weights (5 years averages) 

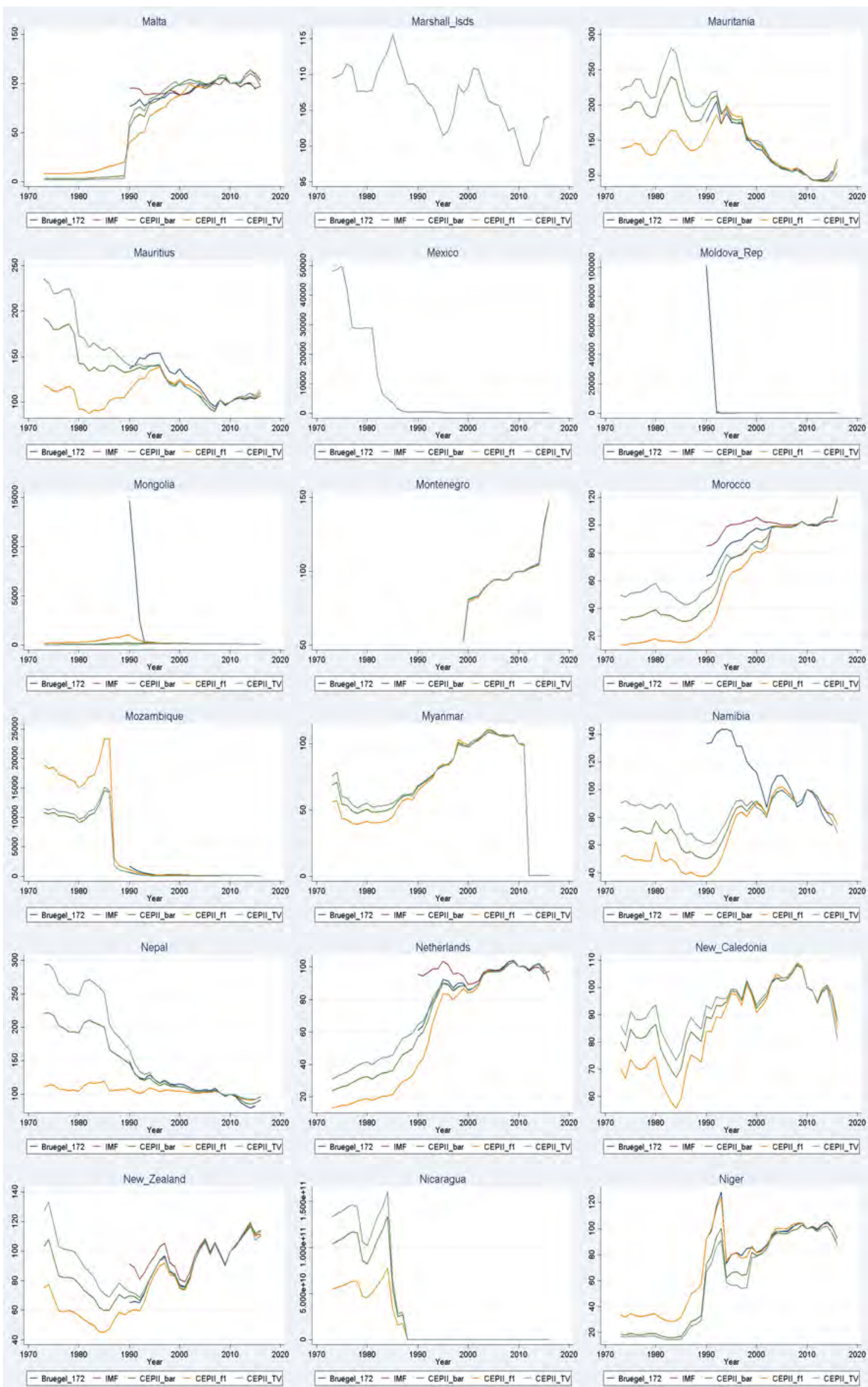

Figure C.1 - (Continued from previous page)

Note: an increase corresponds to an appreciation. "f1": fixed weights 2008-2012; "bar": fixed weights 1973-2016; "TV": time-varying weights (5 years averages) 

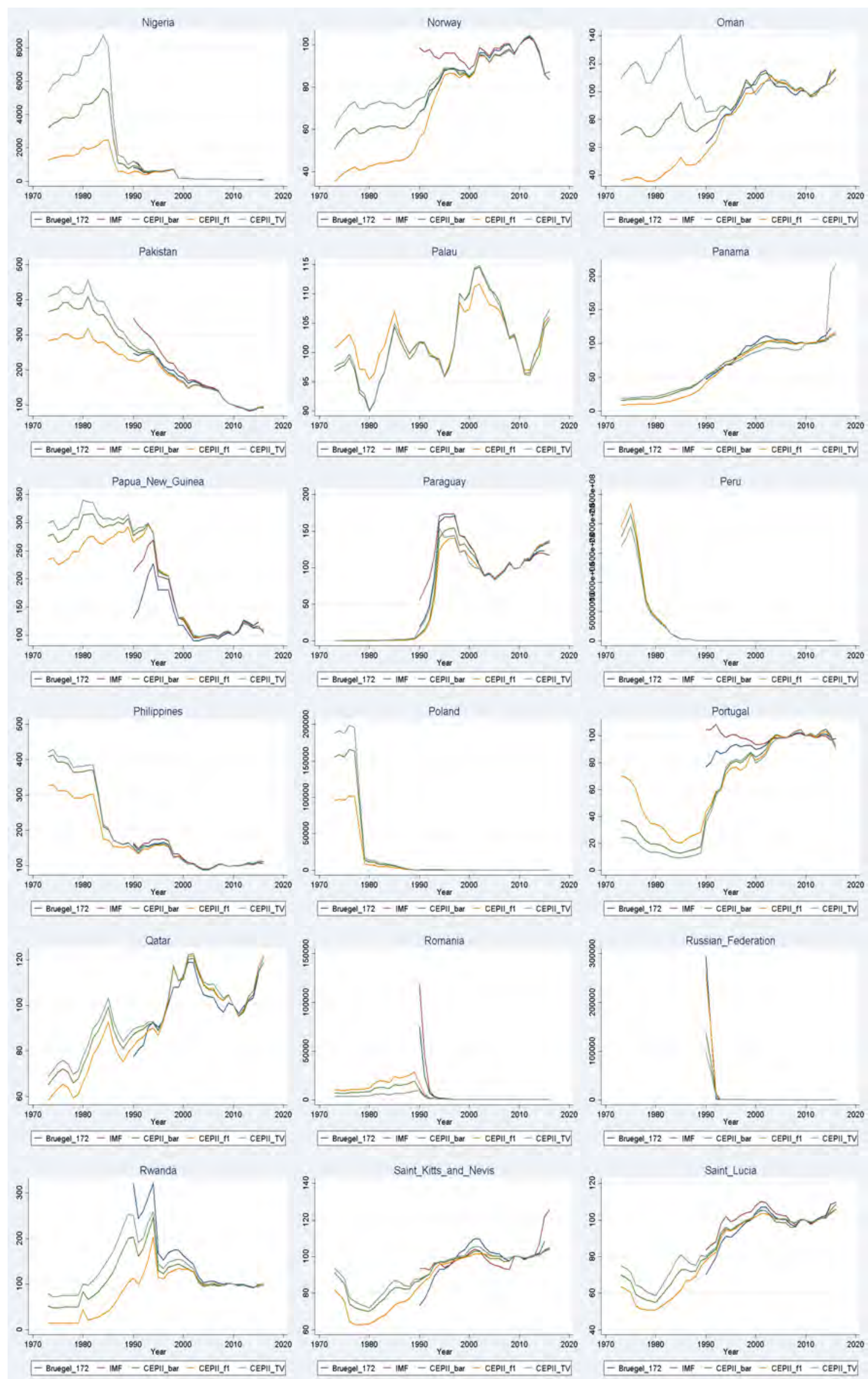

Figure C.1 - (Continued from previous page)

Note: an increase corresponds to an appreciation. "f1": fixed weights 2008-2012; "bar": fixed weights 1973-2016;

"TV": time-varying weights (5 years averages) 

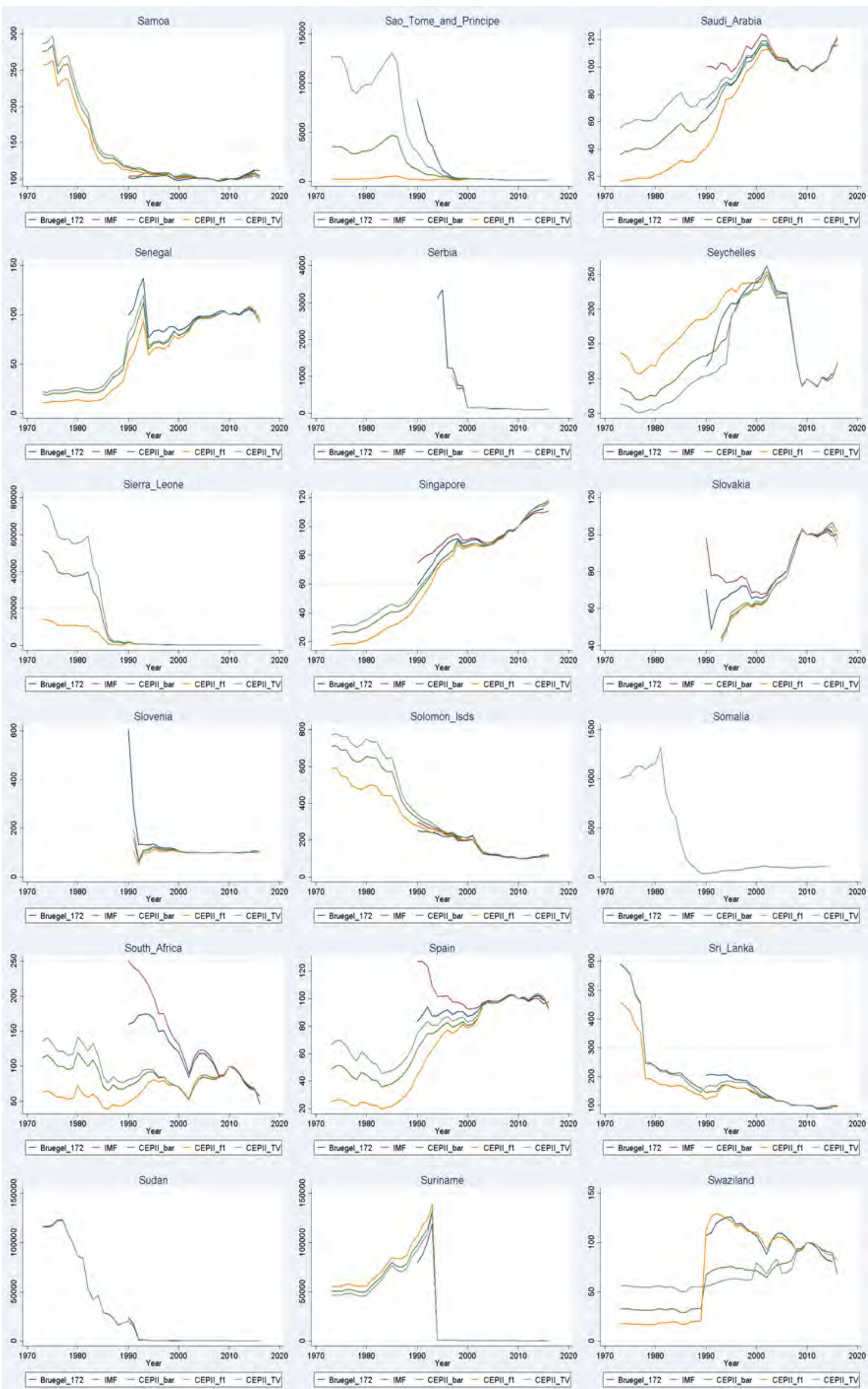

Figure C.1 - (Continued from previous page)

Note: an increase corresponds to an appreciation. "f1": fixed weights 2008-2012; "bar": fixed weights 1973-2016; "TV": time-varying weights (5 years averages) 

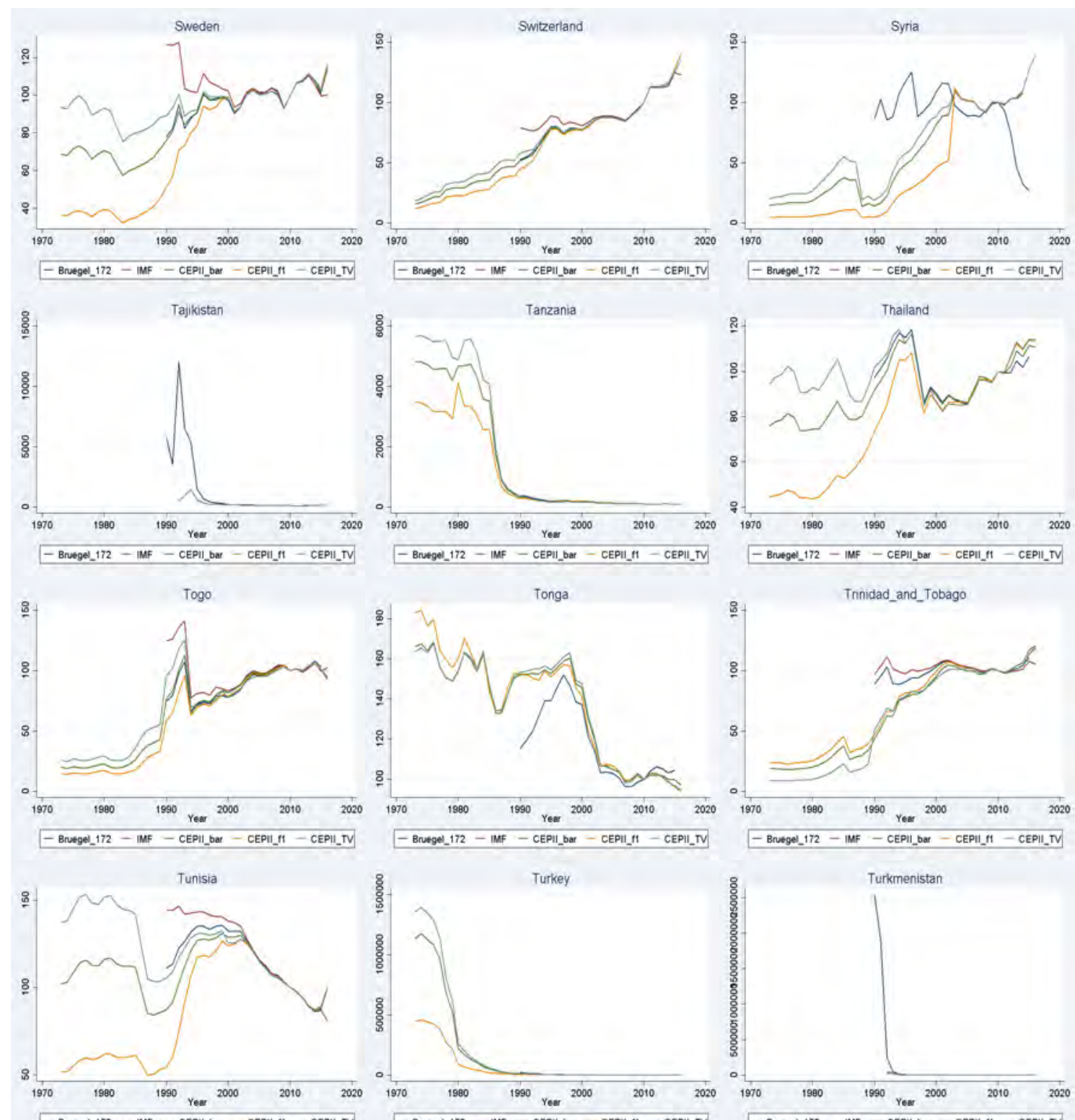

- Brutgel_172 - IMF - CEPII_bat - CEPPI_H - CEPII_TV
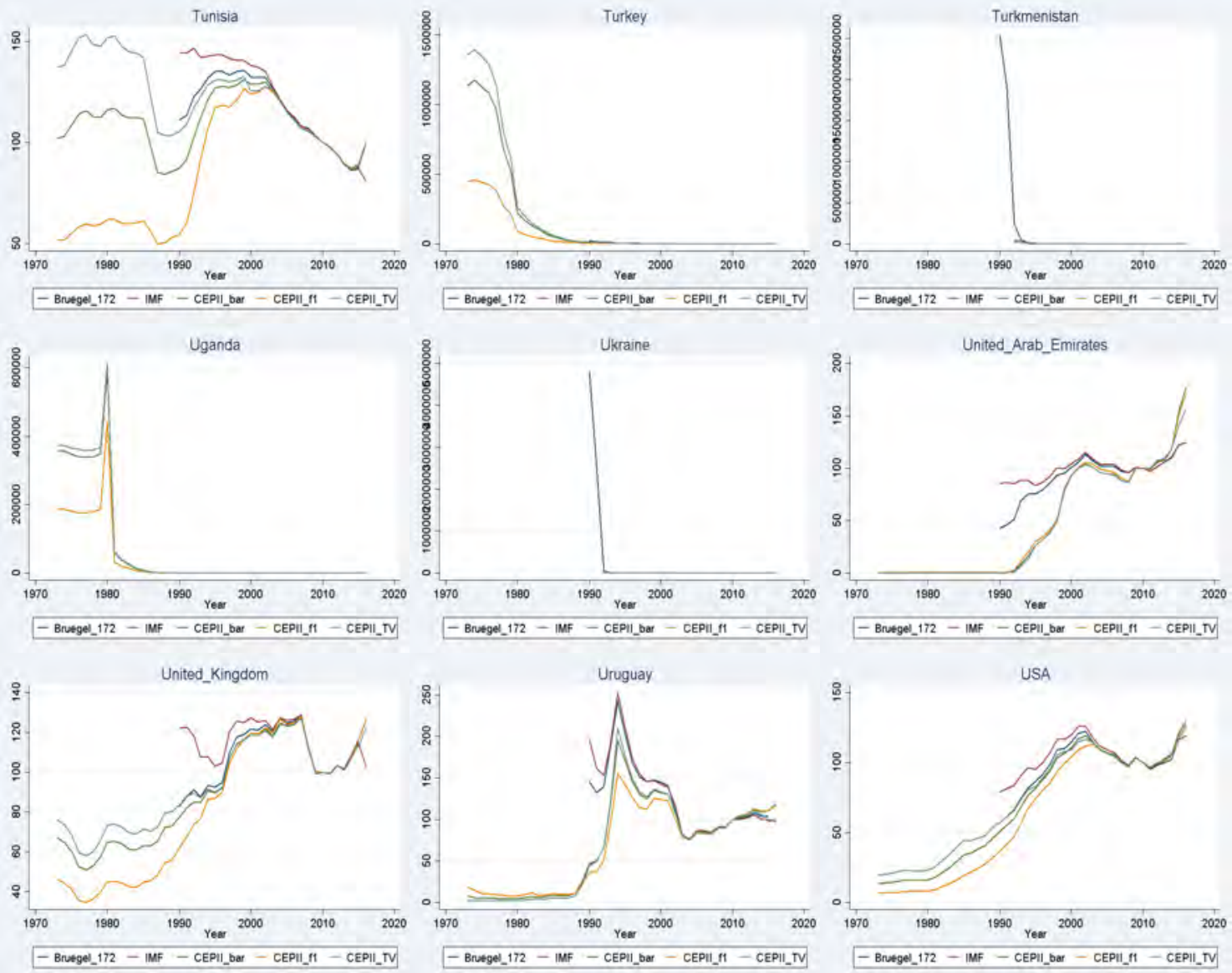

Figure C.1 - (Continued from previous page)

Note: an increase corresponds to an appreciation. "f1": fixed weights 2008-2012; "bar": fixed weights 1973-2016;

"TV": time-varying weights (5 years averages) 

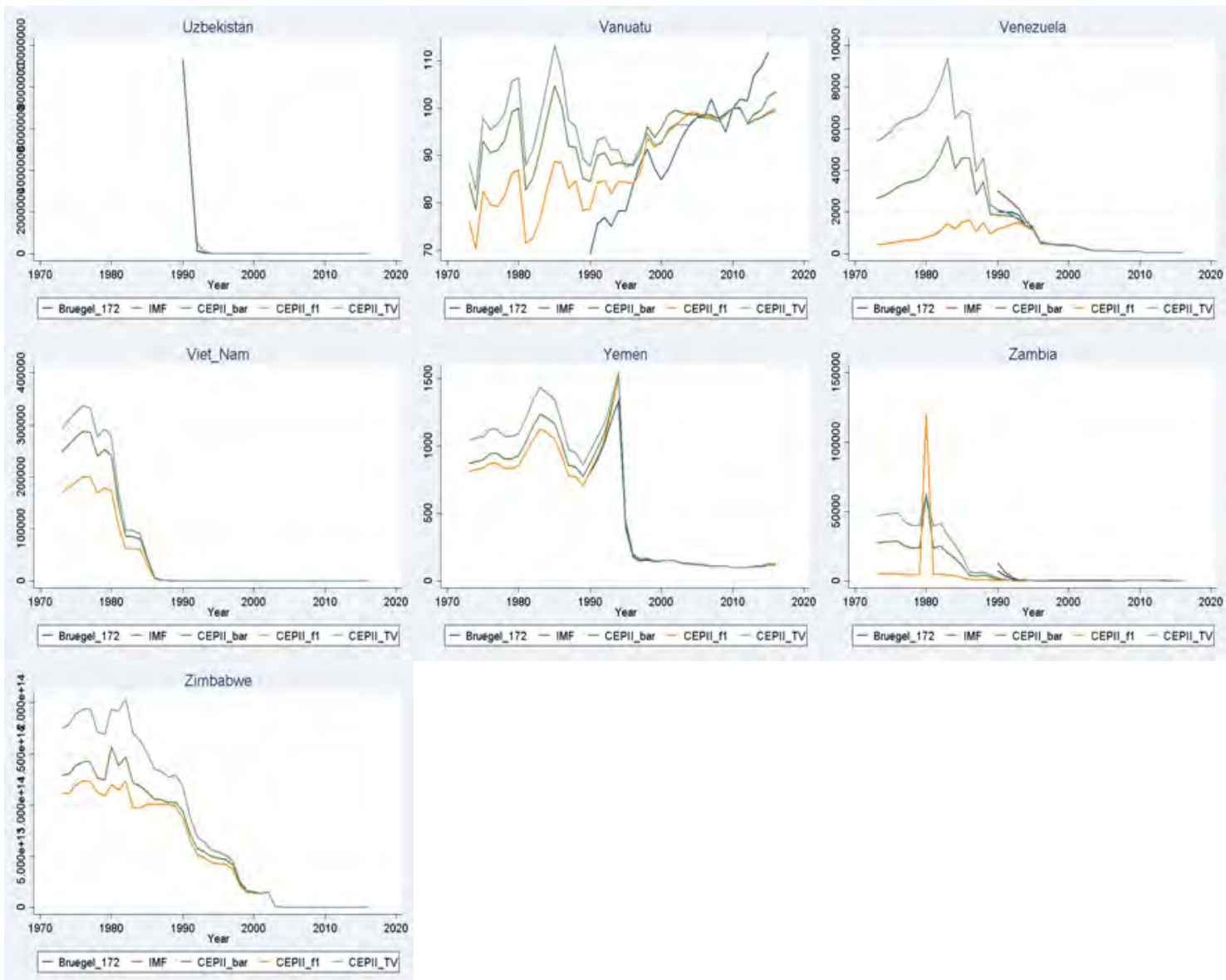

Figure C.1 - (Continued from previous page)

Note: an increase corresponds to an appreciation. "f1": fixed weights 2008-2012; "bar": fixed weights 1973-2016; "TV": time-varying weights (5 years averages) 

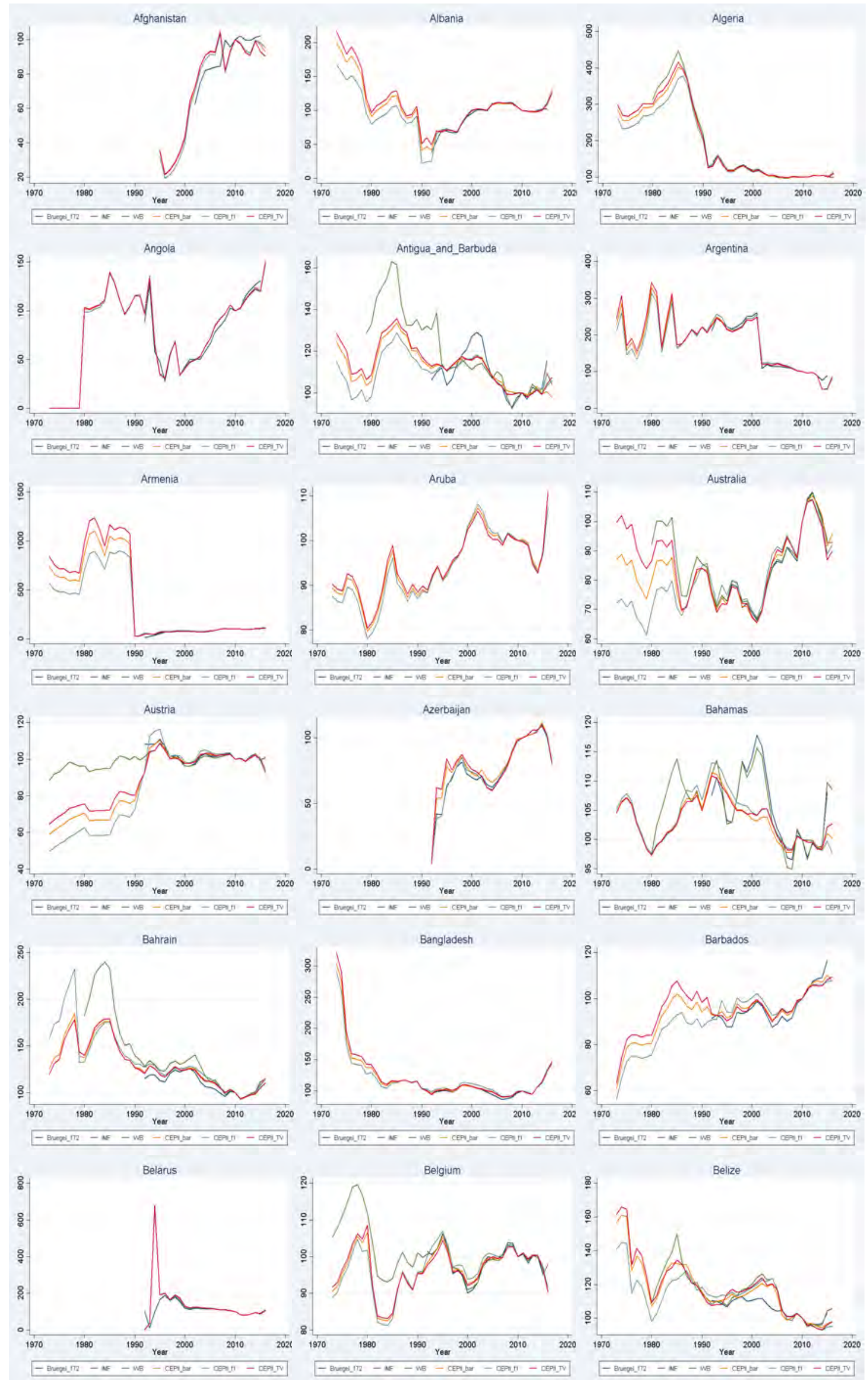

Figure C.2 - Real effective exchange rates $(2010=100)$

Note: an increase corresponds to an appreciation. "f1": fixed weights 2008-2012; "bar": fixed weights 1973-2016; "TV": time-varying weights (5 years averages) 

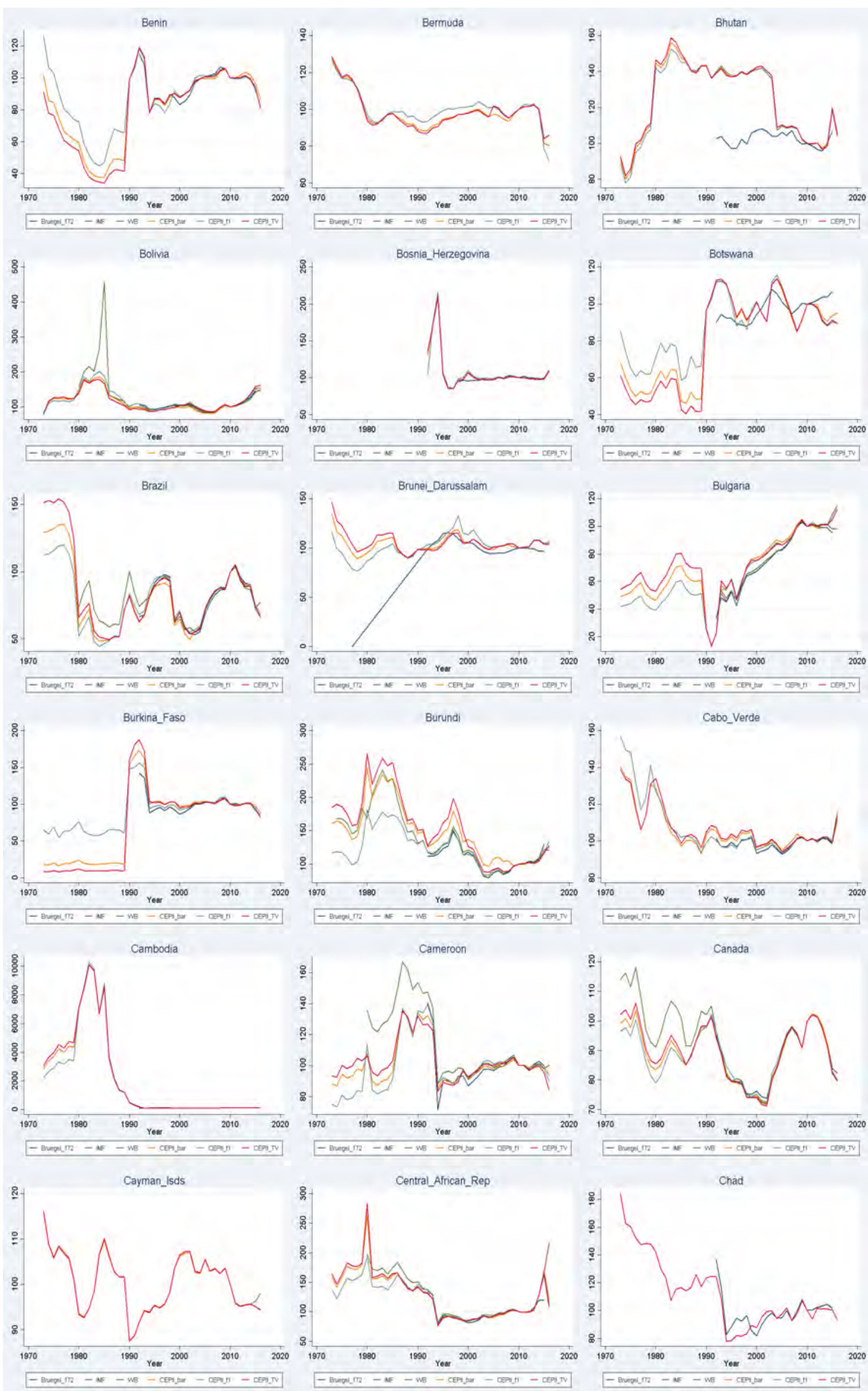

Figure C.2 - (Continued from previous page)

Note: an increase corresponds to an appreciation. "f1": fixed weights 2008-2012; "bar": fixed weights 1973-2016; "TV": time-varying weights (5 years averages) 

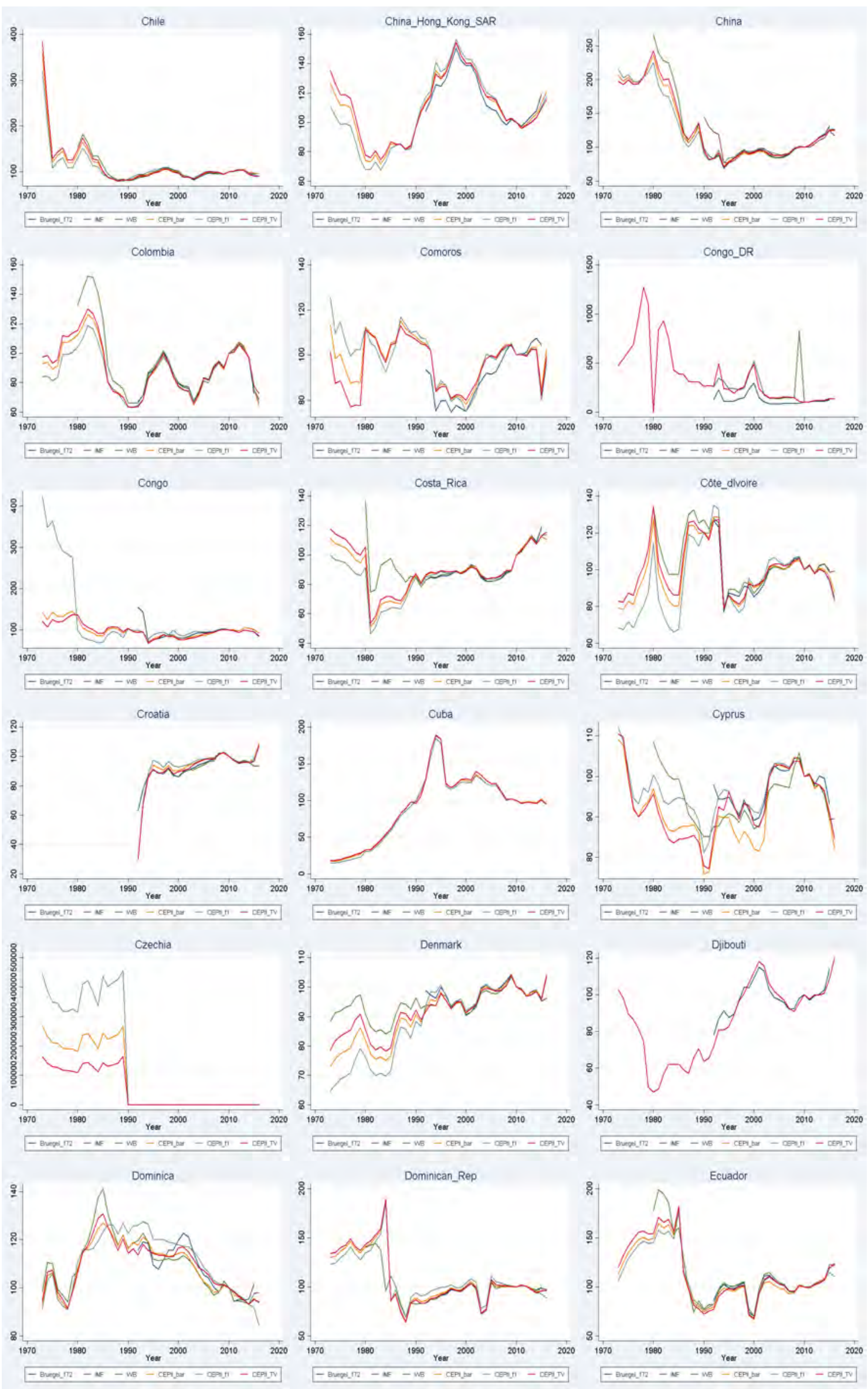

Figure C.2 - (Continued from previous page)

Note: an increase corresponds to an appreciation. "f1": fixed weights 2008-2012; "bar": fixed weights 1973-2016;

"TV": time-varying weights (5 years averages) 

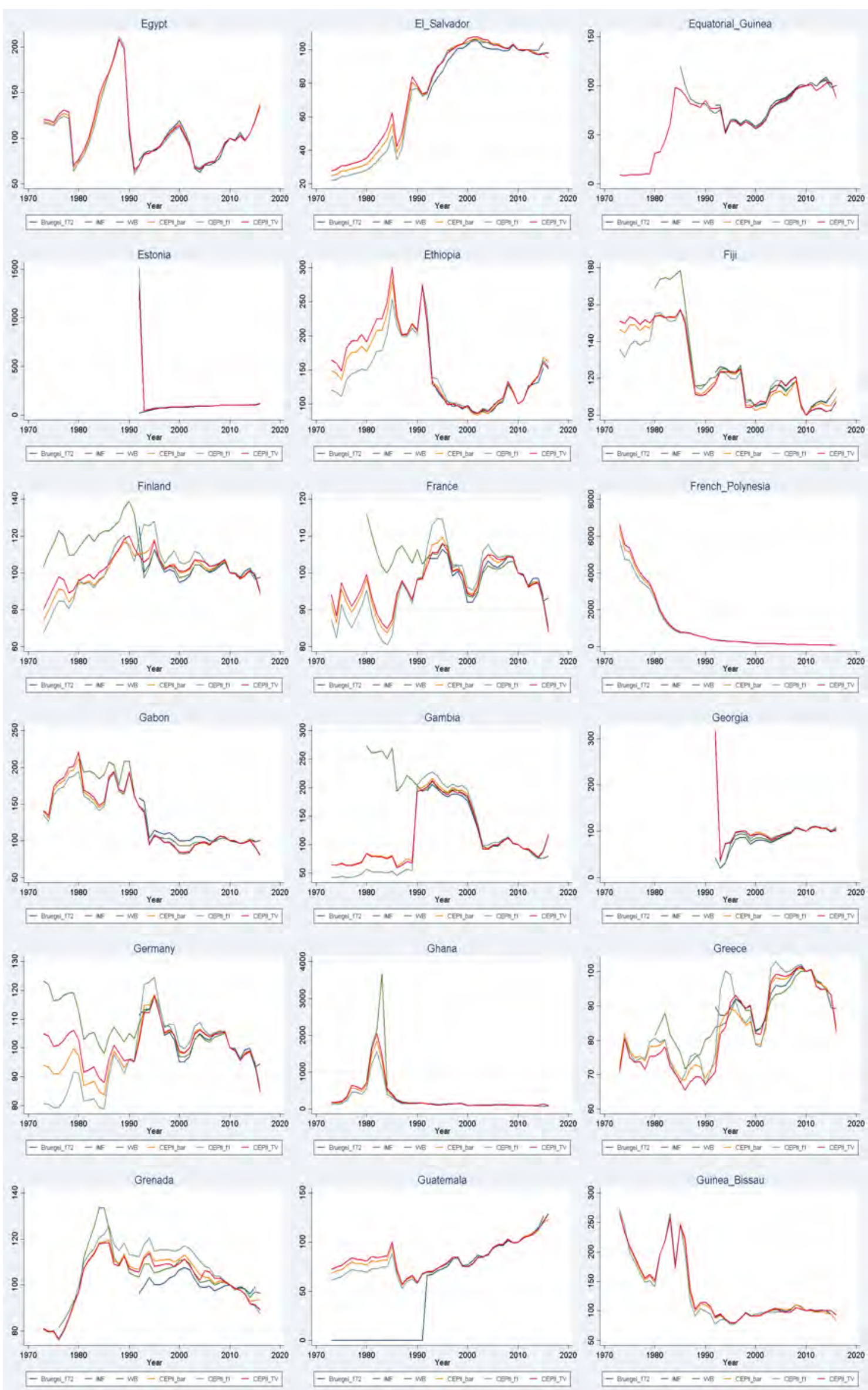

Figure C.2 - (Continued from previous page)

Note: an increase corresponds to an appreciation. "f1": fixed weights 2008-2012; "bar": fixed weights 1973-2016; "TV": time-varying weights (5 years averages) 

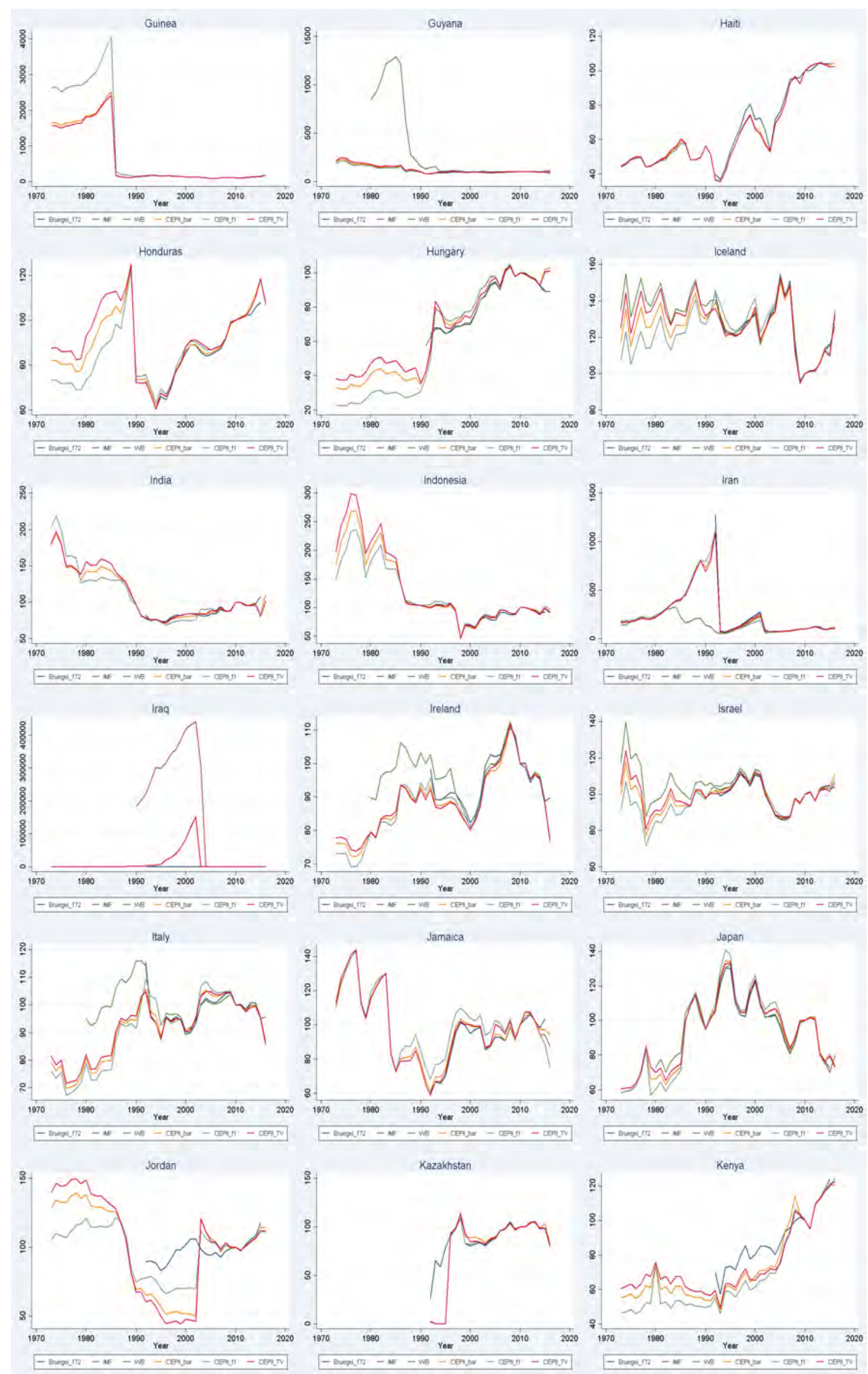

Figure C.2 - (Continued from previous page)

Note: an increase corresponds to an appreciation. "f1": fixed weights 2008-2012; "bar": fixed weights 1973-2016;

"TV": time-varying weights (5 years averages) 

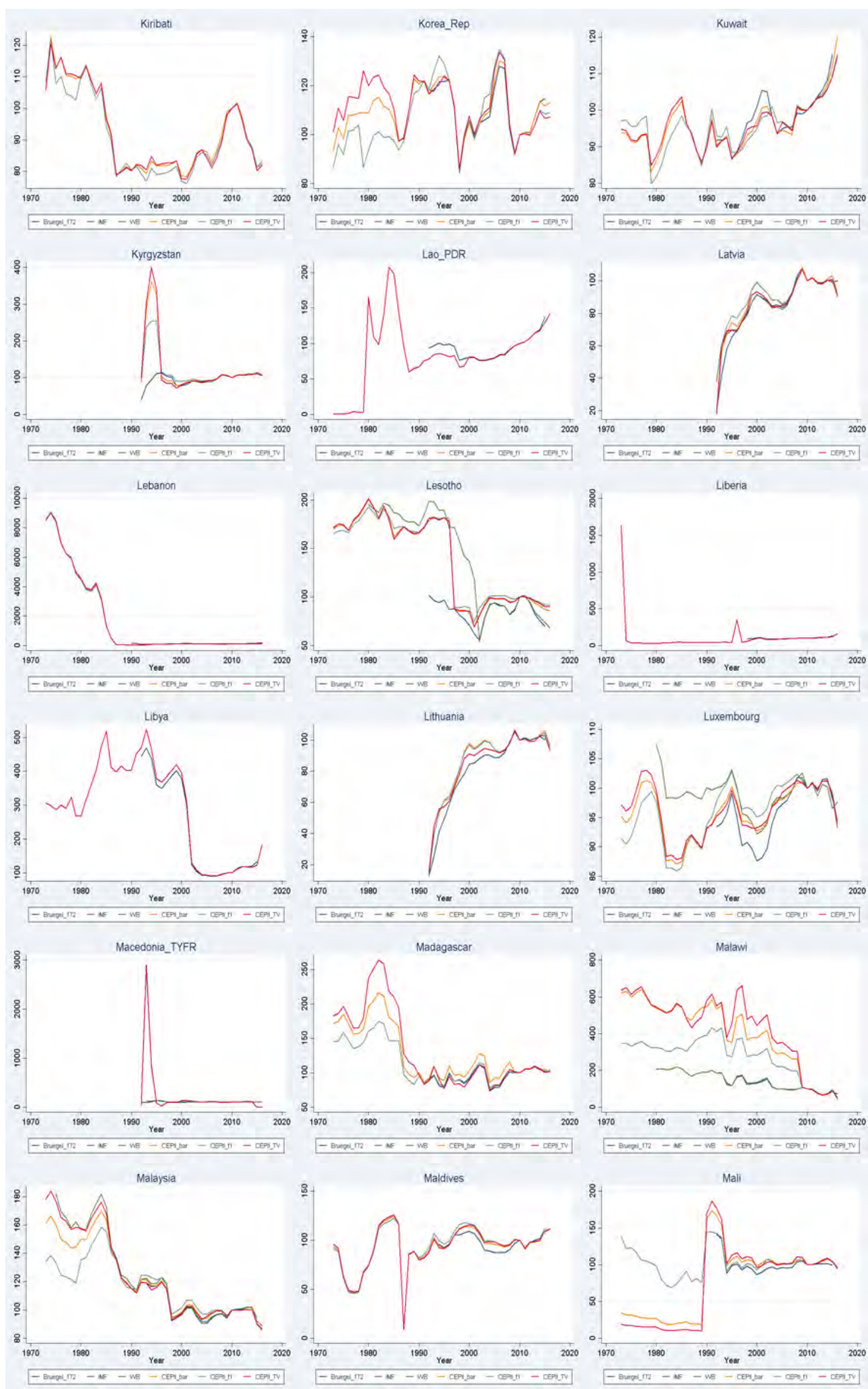

Figure C.2 - (Continued from previous page)

Note: an increase corresponds to an appreciation. "f1": fixed weights 2008-2012; "bar": fixed weights 1973-2016; "TV": time-varying weights (5 years averages) 

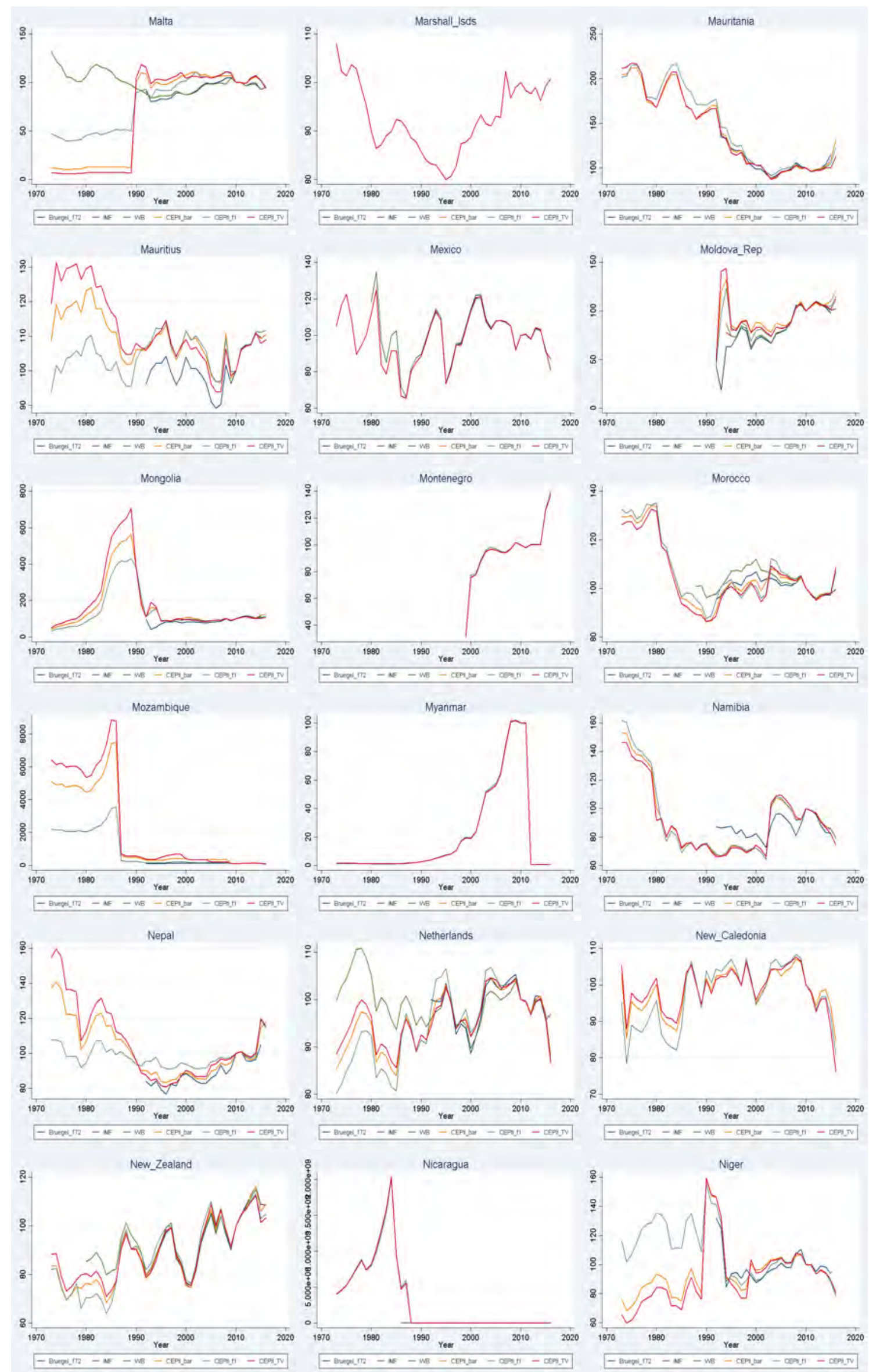

Figure C.2 - (Continued from previous page)

Note: an increase corresponds to an appreciation. "f1": fixed weights 2008-2012; "bar": fixed weights 1973-2016;

"TV": time-varying weights (5 years averages) 

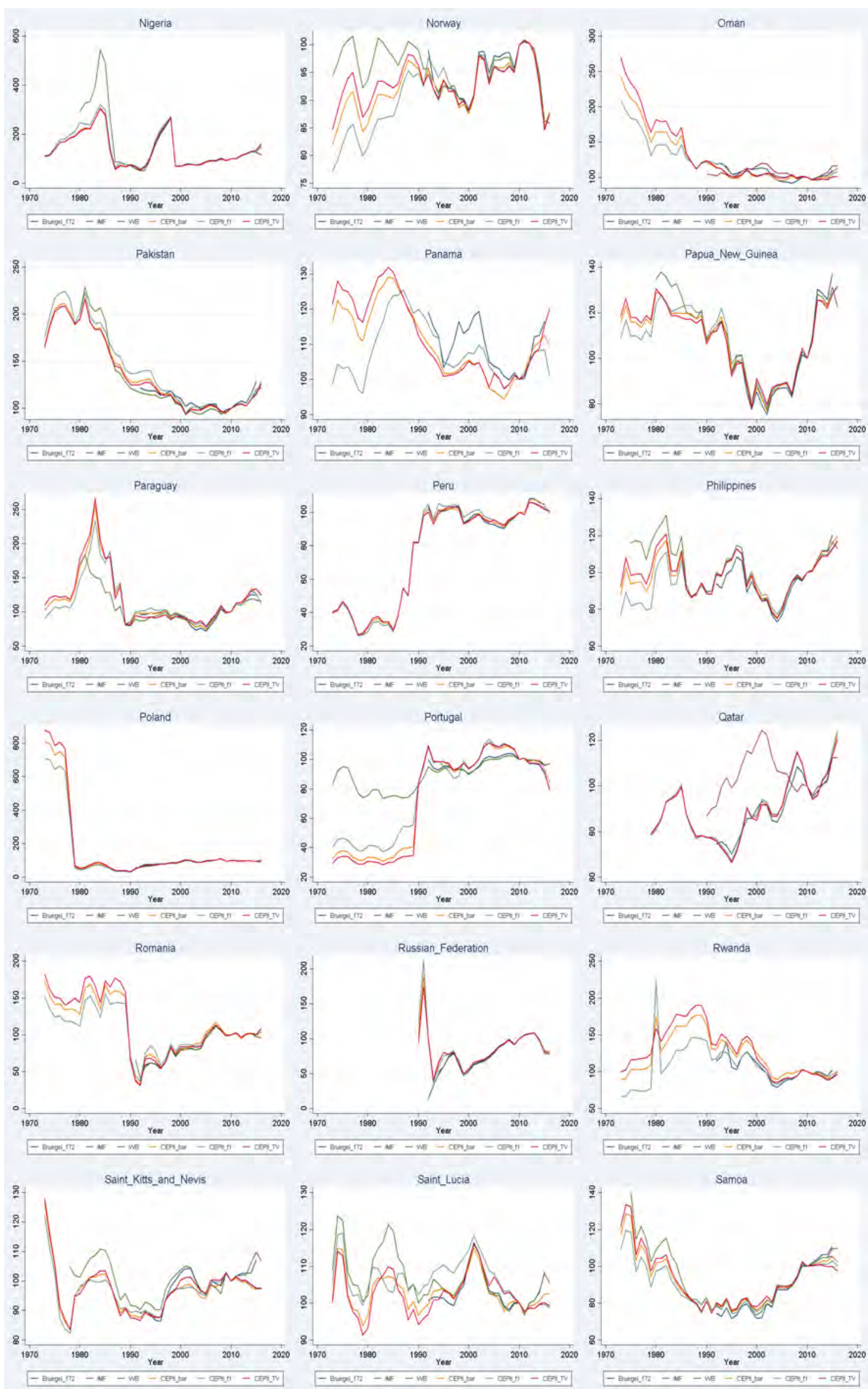

Figure C.2 - (Continued from previous page)

Note: an increase corresponds to an appreciation. "f1": fixed weights 2008-2012; "bar": fixed weights 1973-2016; "TV": time-varying weights (5 years averages) 

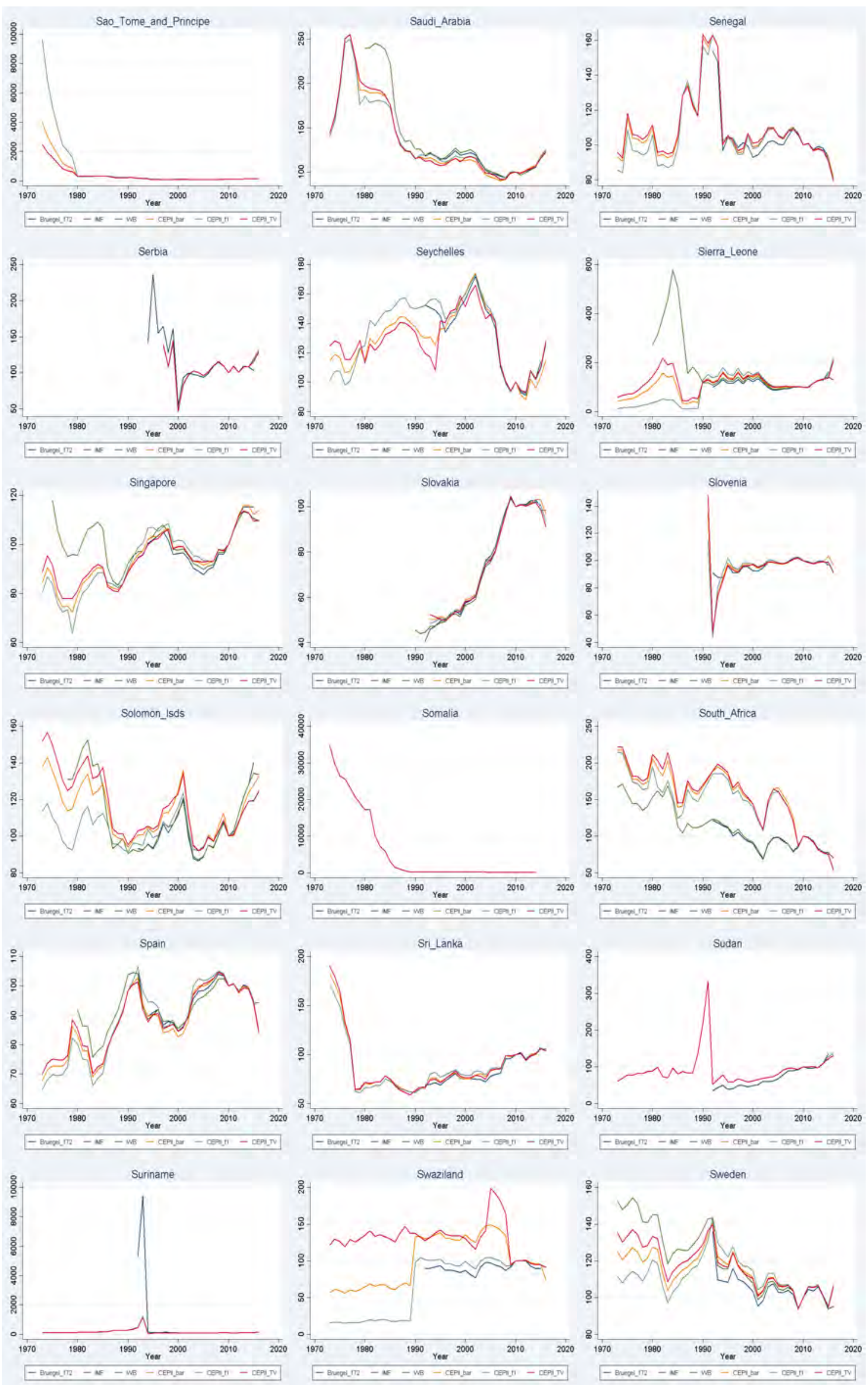

Figure C.2 - (Continued from previous page)

Note: an increase corresponds to an appreciation. "f1": fixed weights 2008-2012; "bar": fixed weights 1973-2016;

"TV": time-varying weights (5 years averages) 

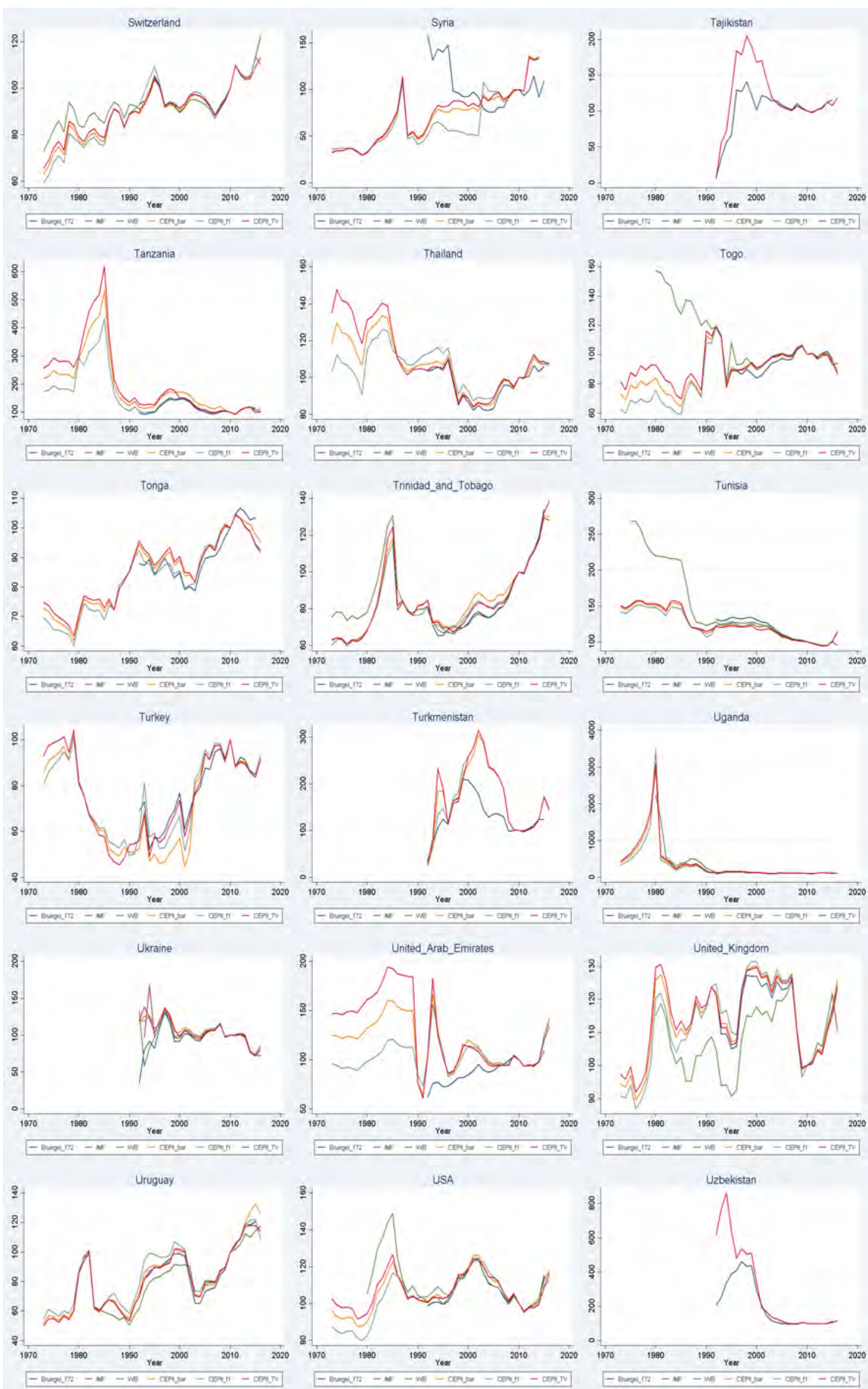

Figure C.2 - (Continued from previous page)

Note: an increase corresponds to an appreciation. "f1": fixed weights 2008-2012; "bar": fixed weights 1973-2016; "TV": time-varying weights (5 years averages) 

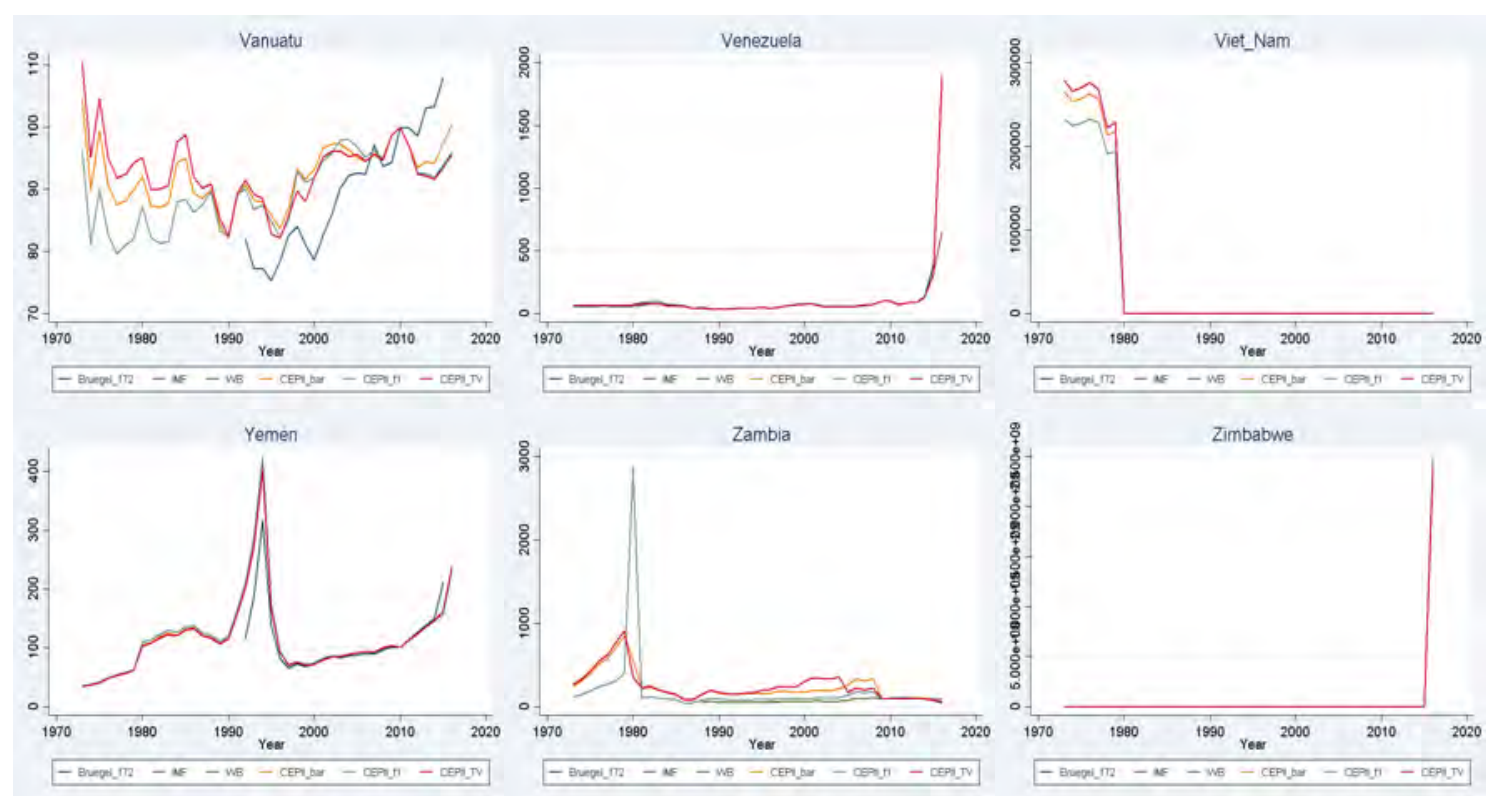

Figure C.2 - (Continued from previous page)

Note: an increase corresponds to an appreciation. "f1": fixed weights 2008-2012; "bar": fixed weights 1973-2016; "TV": time-varying weights (5 years averages) 


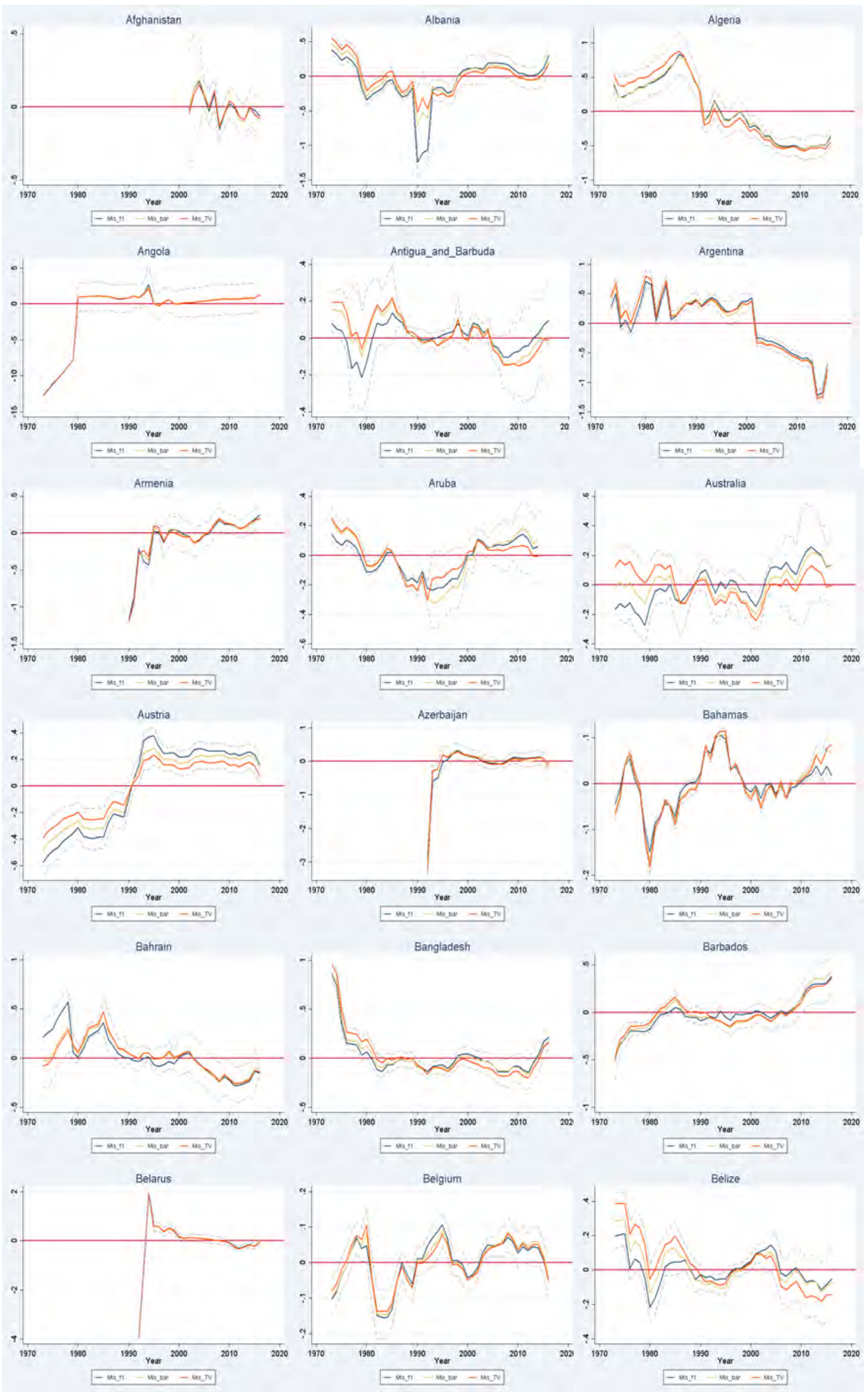

Figure C.3 - Exchange rate misalignments (\%)

Note: a positive (resp. negative) currency misalignment corresponds to an overvaluation (resp. undervaluation). Each of the series represents the average over all the different estimated models by weighting systems ("f1" and "bar" are fixed weights based on the 2008-2012 and 1973-2016 periods, respectively; "TV" indicates time-varying weights (5-years window). The dashed lines indicate the $95 \%$ confidence interval of the average currency misalignment, regardless of the weighting scheme. 

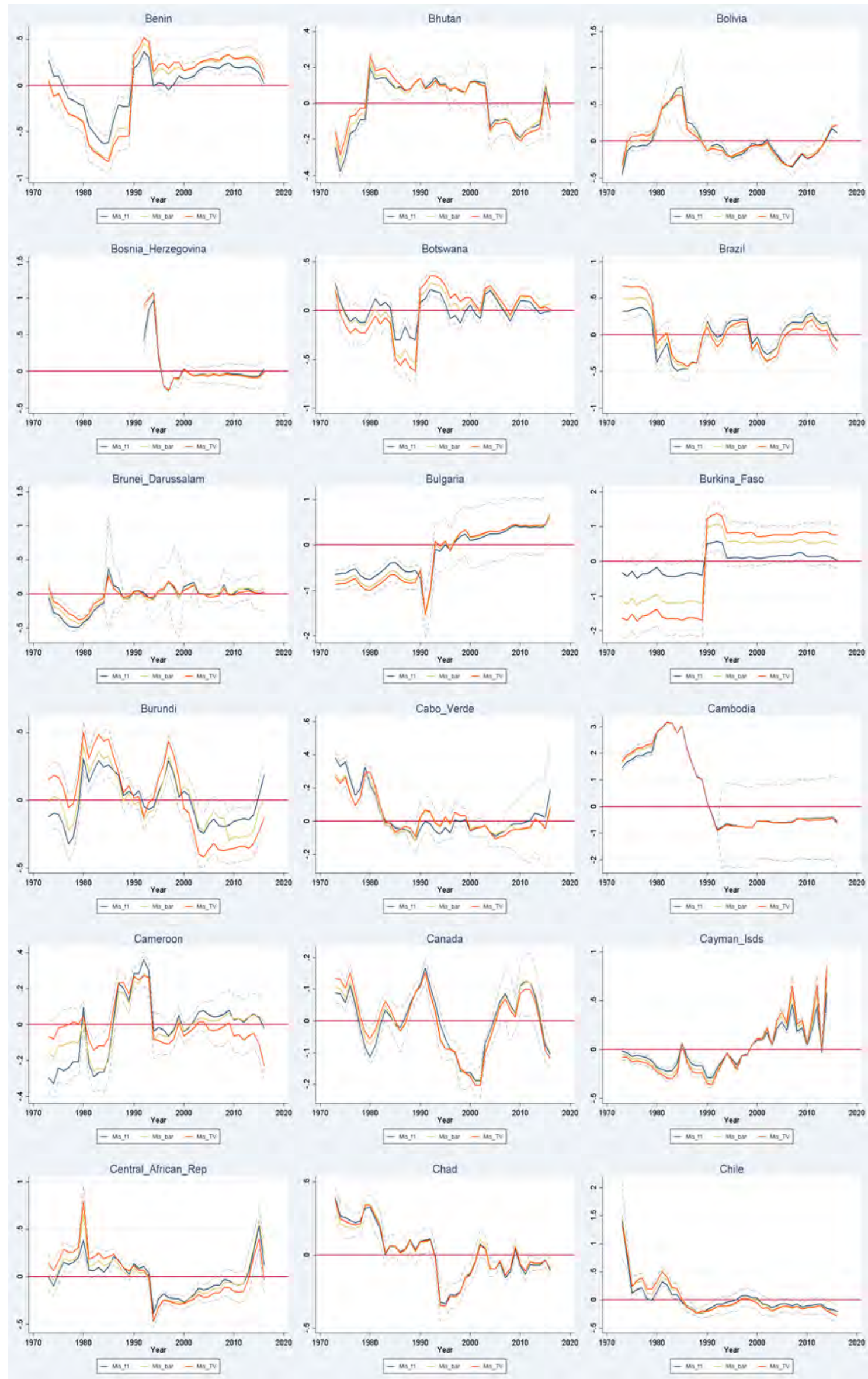

Figure C.3 - (Continued from previous page)

Note: a positive (resp. negative) currency misalignment corresponds to an overvaluation (resp. undervaluation). Each of the series represents the average over all the different estimated models by weighting systems ("f1" and "bar" are fixed weights based on the 2008-2012 and 1973-2016 periods, respectively; "TV" indicates time-varying weights (5-years window). The dashed lines indicate the $95 \%$ confidence interval of the average currency misalignment, regardless of the weighting scheme. 


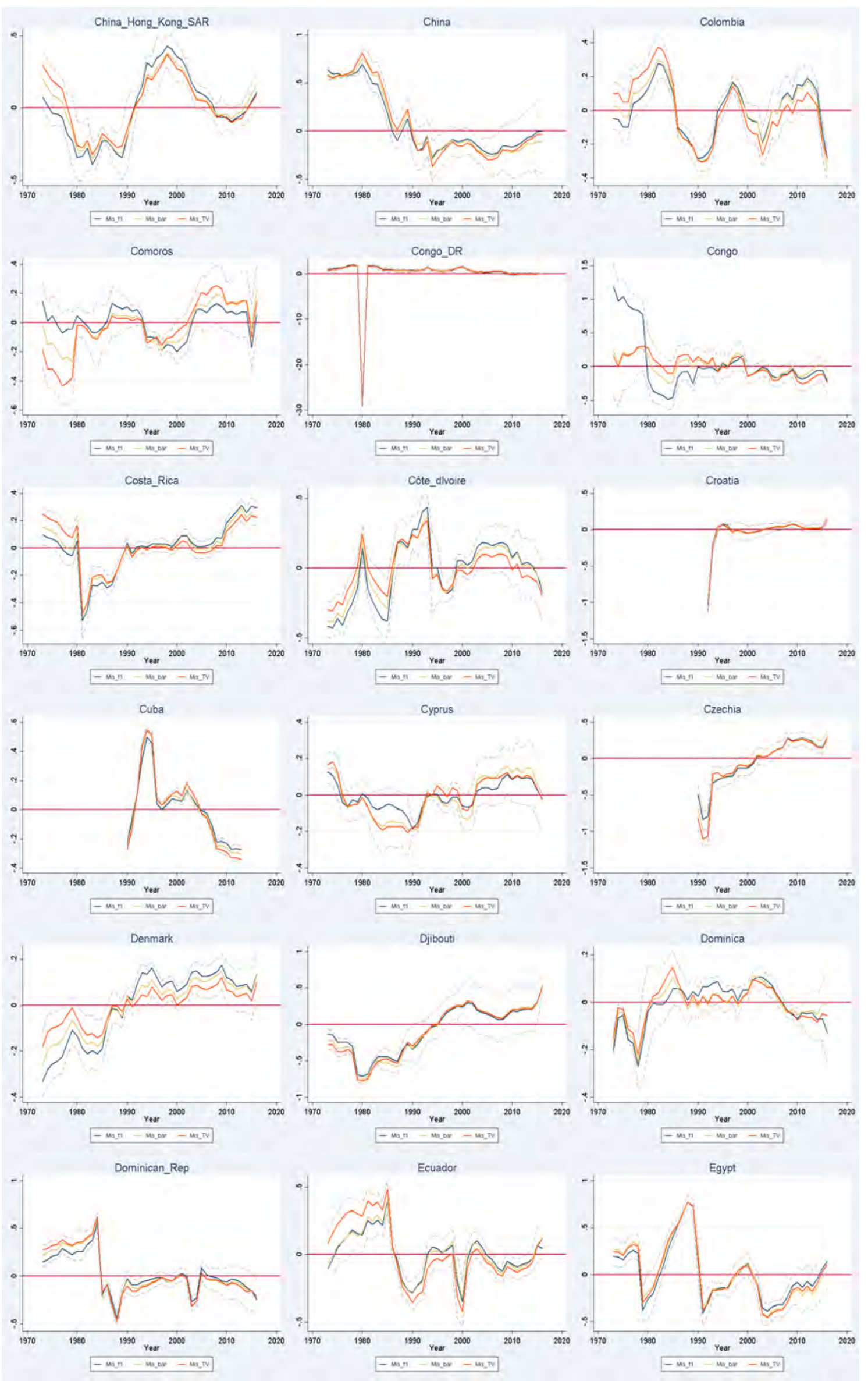

Figure C.3 - (Continued from previous page)

Note: a positive (resp. negative) currency misalignment corresponds to an overvaluation (resp. undervaluation). Each of the series represents the average over all the different estimated models by weighting systems (" $f 1$ " and "bar" are fixed weights based on the 2008-2012 and 1973-2016 periods, respectively; "TV" indicates time-varying weights (5-years window). The dashed lines indicate the $95 \%$ confidence interval of the average currency misalignment, regardless of the weighting scheme. 


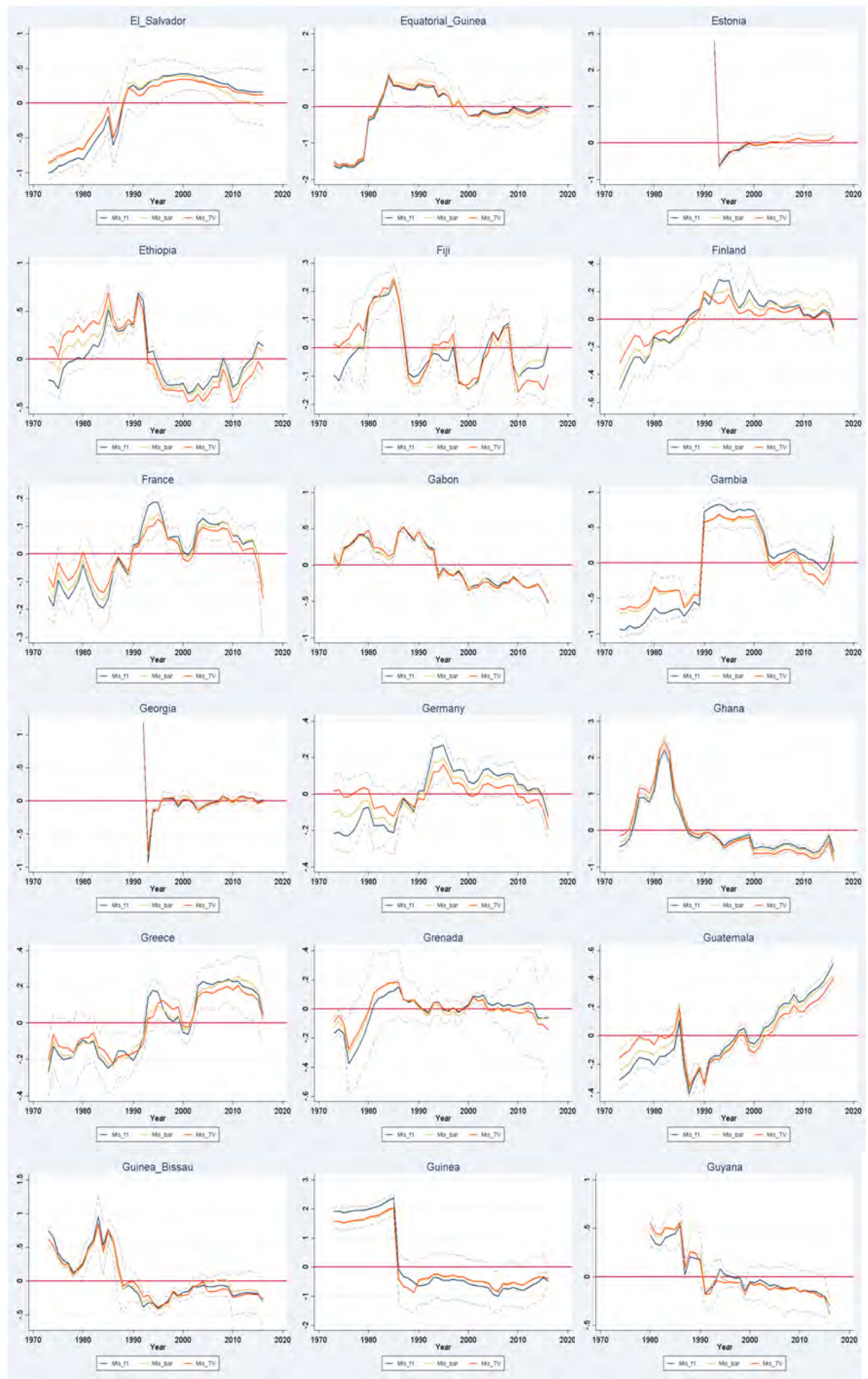

Figure C.3 - (Continued from previous page)

Note: a positive (resp. negative) currency misalignment corresponds to an overvaluation (resp. undervaluation). Each of the series represents the average over all the different estimated models by weighting systems ("f1" and "bar" are fixed weights based on the 2008-2012 and 1973-2016 periods, respectively; "TV" indicates time-varying weights (5-years window). The dashed lines indicate the $95 \%$ confidence interval of the average currency misalignment, regardless of the weighting scheme. 


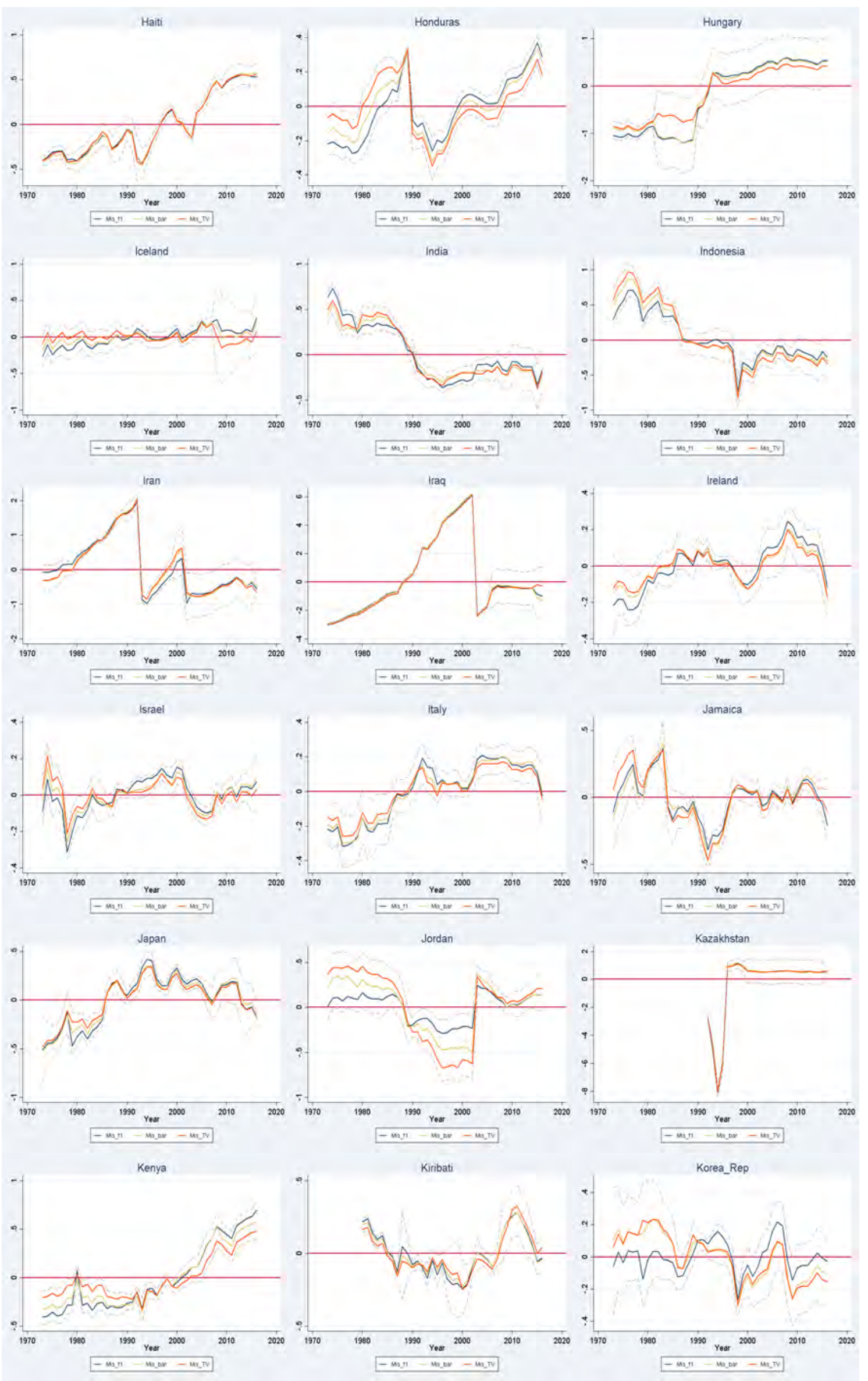

Figure C.3 - (Continued from previous page)

Note: a positive (resp. negative) currency misalignment corresponds to an overvaluation (resp. undervaluation). Each of the series represents the average over all the different estimated models by weighting systems ("f 1 " and "bar" are fixed weights based on the 2008-2012 and 1973-2016 periods, respectively; "TV" indicates time-varying weights (5-years window). The dashed lines indicate the $95 \%$ confidence interval of the average currency misalignment, regardless of the weighting scheme. 


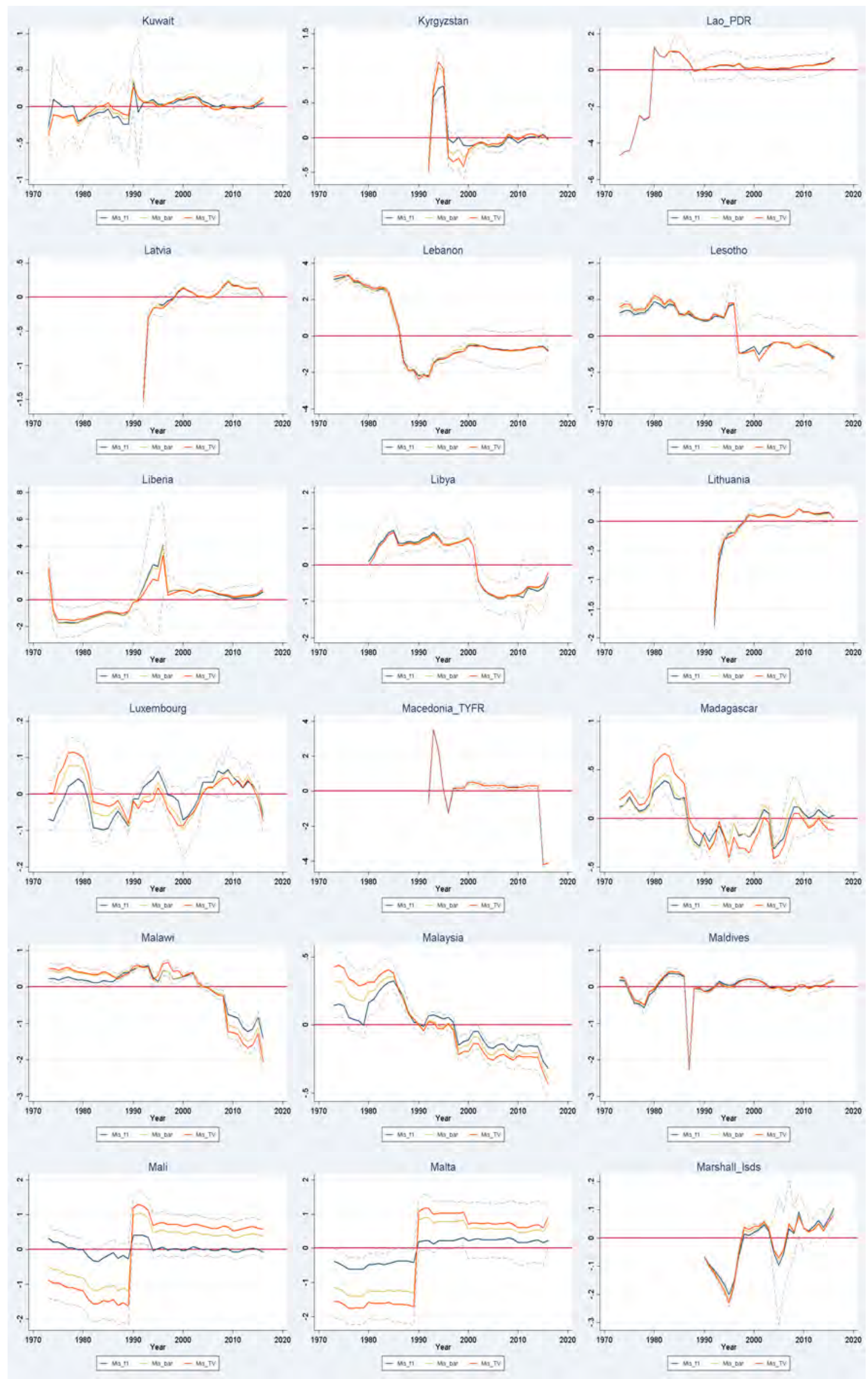

Figure C.3 - (Continued from previous page)

Note: a positive (resp. negative) currency misalignment corresponds to an overvaluation (resp. undervaluation). Each of the series represents the average over all the different estimated models by weighting systems ("f1" and "bar" are fixed weights based on the 2008-2012 and 1973-2016 periods, respectively; "TV" indicates time-varying weights (5-years window). The dashed lines indicate the $95 \%$ confidence interval of the average currency misalignment, regardless of the weighting scheme. 


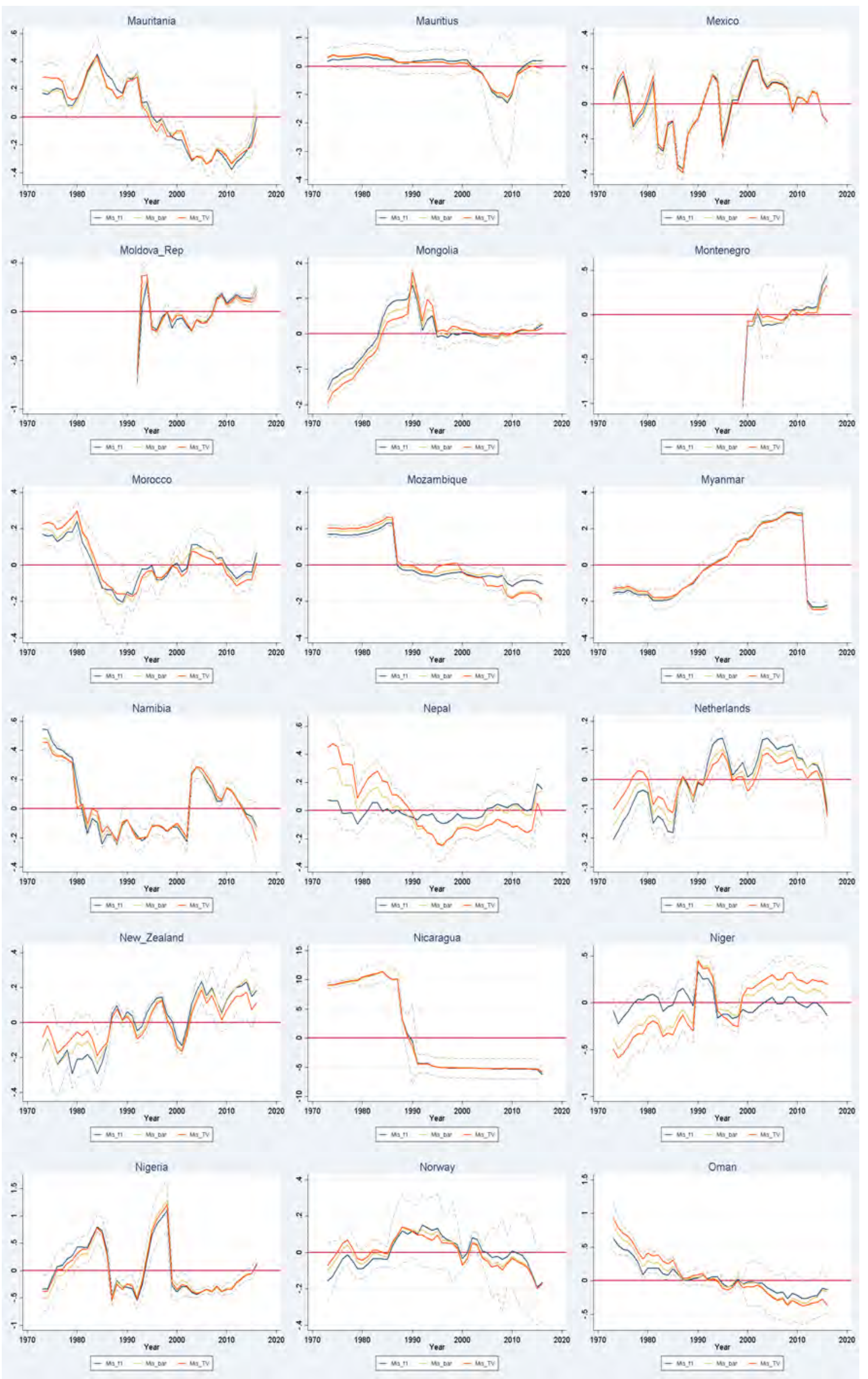

Figure C.3 - (Continued from previous page)

Note: a positive (resp. negative) currency misalignment corresponds to an overvaluation (resp. undervaluation). Each of the series represents the average over all the different estimated models by weighting systems (" $f 1$ " and "bar" are fixed weights based on the 2008-2012 and 1973-2016 periods, respectively; "TV" indicates time-varying weights (5-years window). The dashed lines indicate the $95 \%$ confidence interval of the average currency misalignment, regardless of the weighting scheme. 


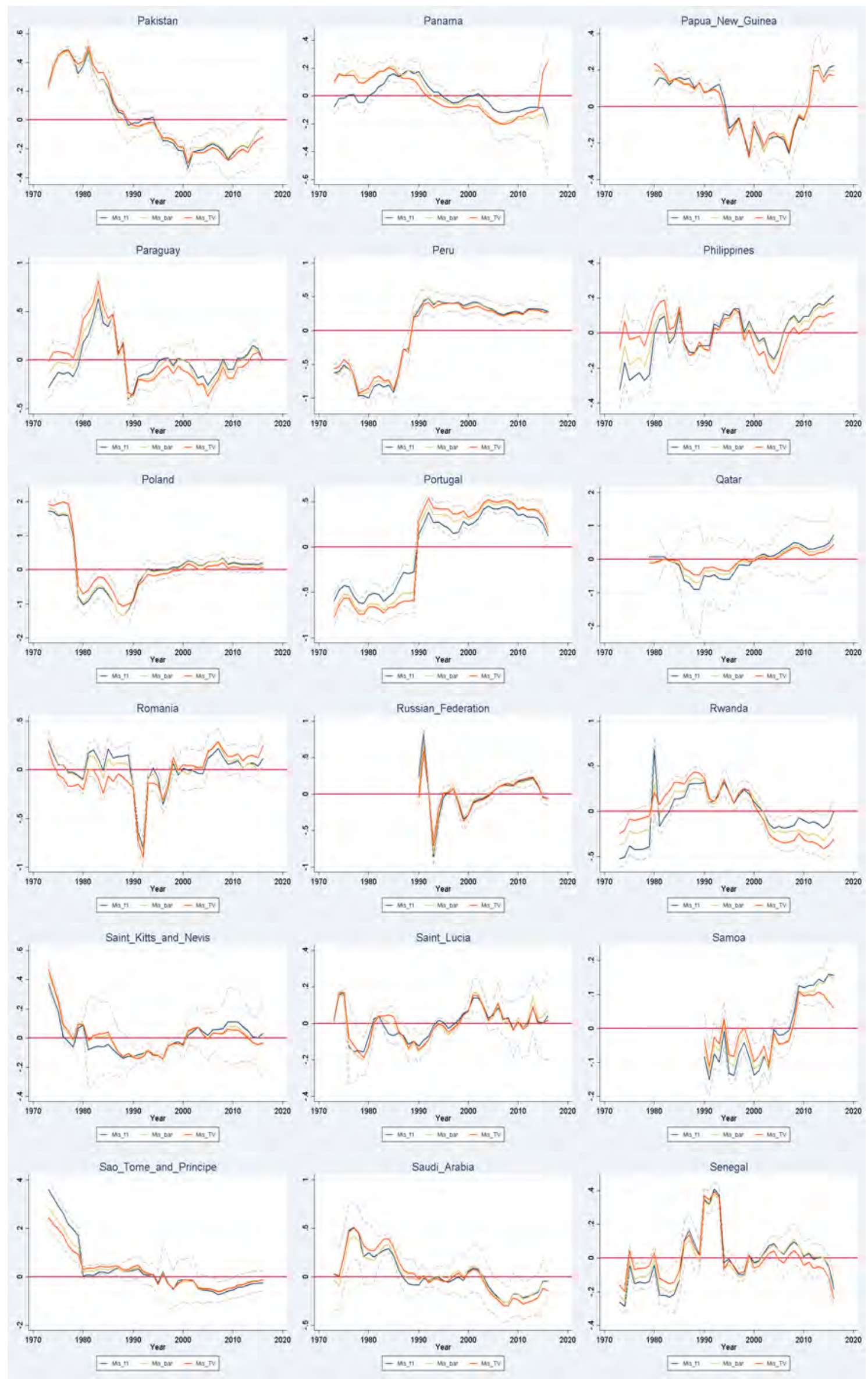

Figure C.3 - (Continued from previous page)

Note: a positive (resp. negative) currency misalignment corresponds to an overvaluation (resp. undervaluation). Each of the series represents the average over all the different estimated models by weighting systems ("f1" and "bar" are fixed weights based on the 2008-2012 and 1973-2016 periods, respectively; "TV" indicates time-varying weights (5-years window). The dashed lines indicate the $95 \%$ confidence interval of the average currency misalignment, regardless of the weighting scheme. 


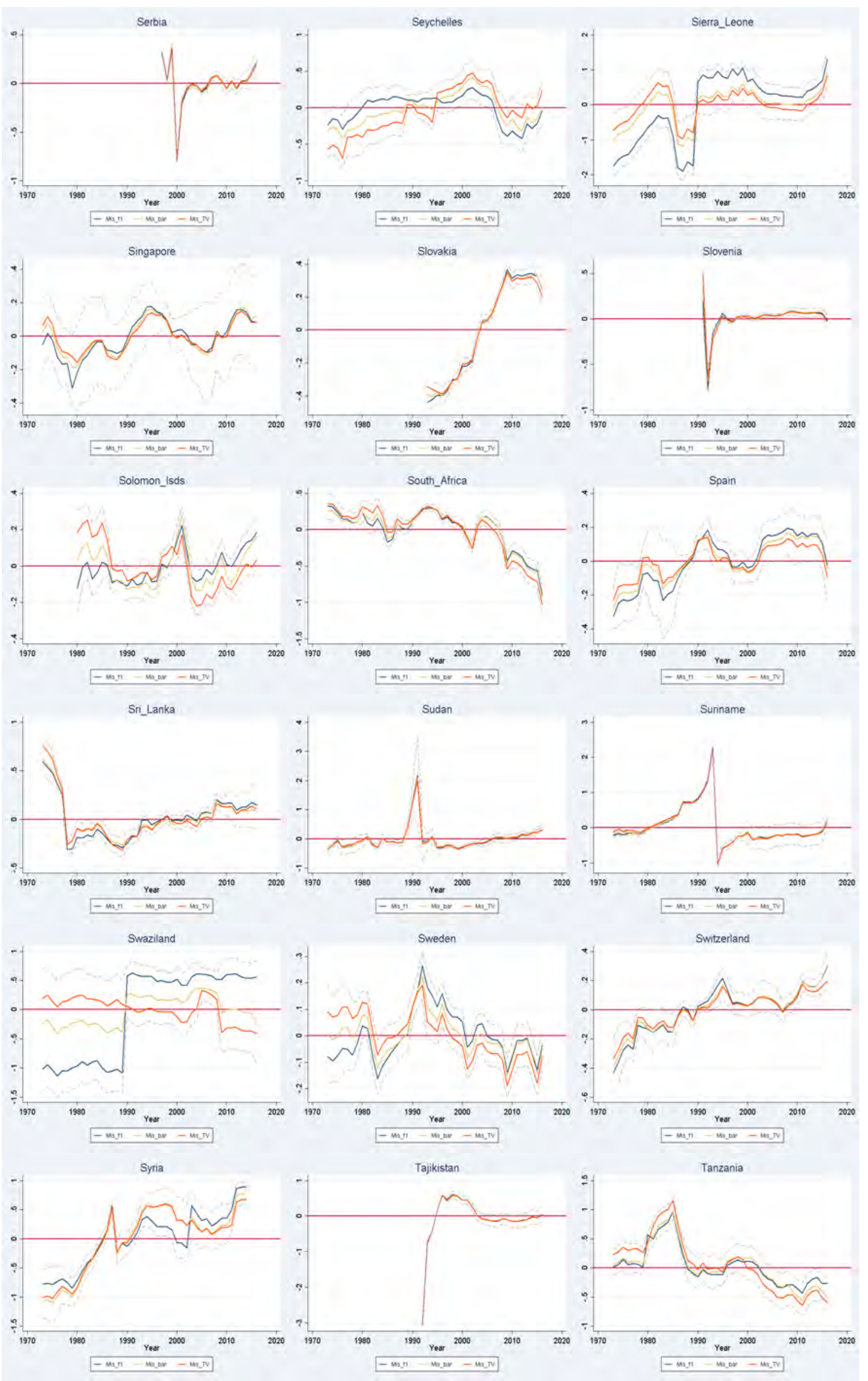

Figure C.3 - (Continued from previous page)

Note: a positive (resp. negative) currency misalignment corresponds to an overvaluation (resp. undervaluation). Each of the series represents the average over all the different estimated models by weighting systems (" $f 1$ " and "bar" are fixed weights based on the 2008-2012 and 1973-2016 periods, respectively; "TV" indicates time-varying weights (5-years window). The dashed lines indicate the $95 \%$ confidence interval of the average currency misalignment, regardless of the weighting scheme. 


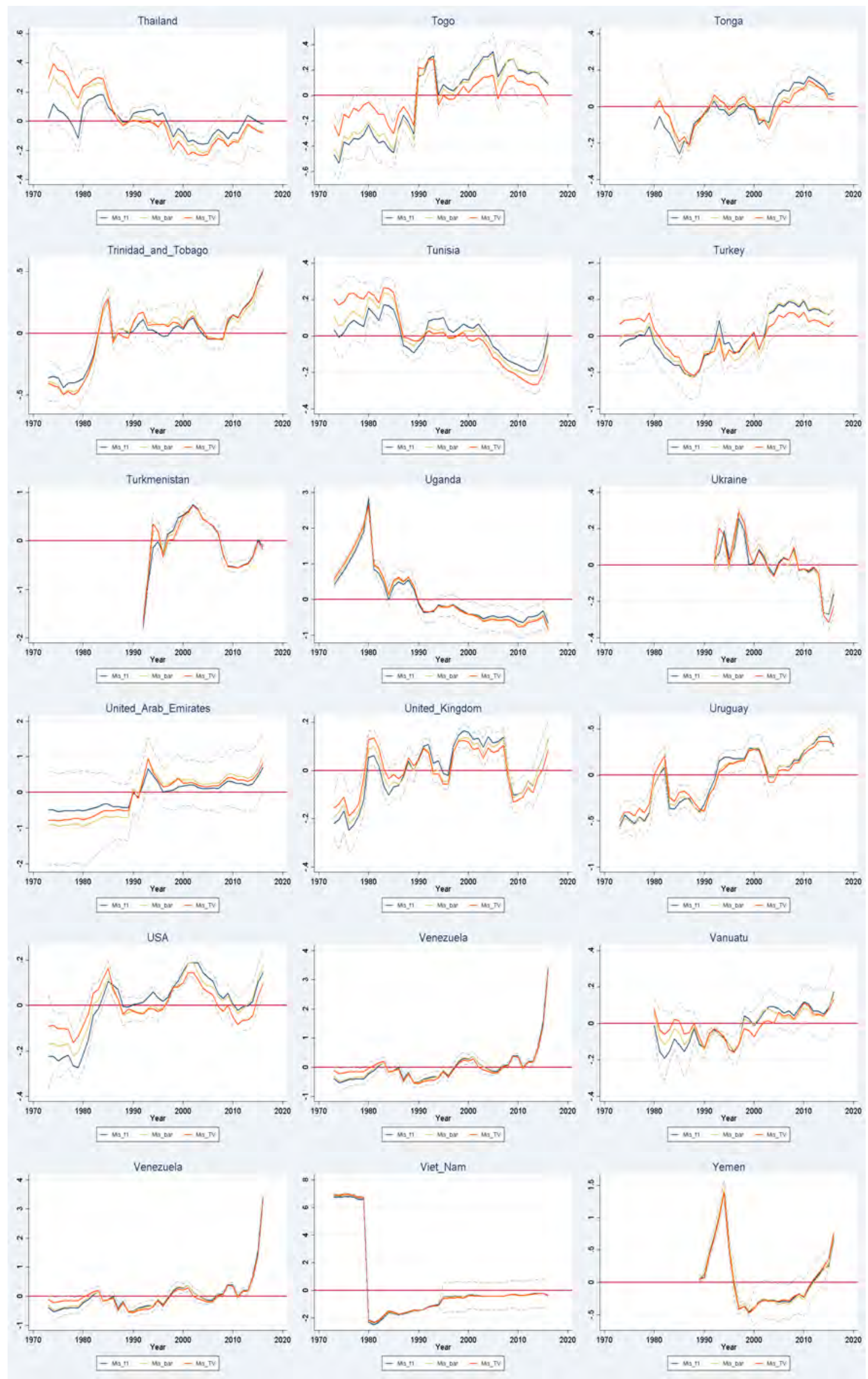

Figure C.3 - (Continued from previous page)

Note: a positive (resp. negative) currency misalignment corresponds to an overvaluation (resp. undervaluation). Each of the series represents the average over all the different estimated models by weighting systems ("f1" and "bar" are fixed weights based on the 2008-2012 and 1973-2016 periods, respectively; "TV" indicates time-varying weights (5-years window). The dashed lines indicate the $95 \%$ confidence interval of the average currency misalignment, regardless of the weighting scheme. 


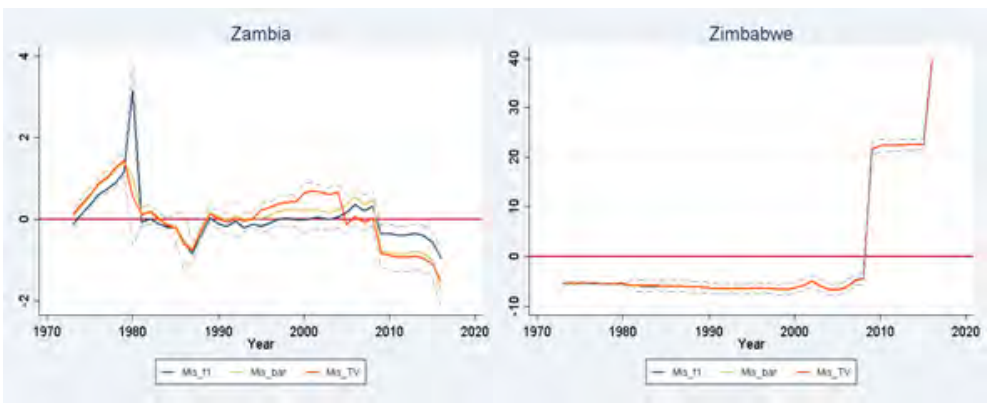

Figure C.3 - (Continued from previous page)

Note: a positive (resp. negative) currency misalignment corresponds to an overvaluation (resp. undervaluation). Each of the series represents the average over all the different estimated models by weighting systems ("f1" and "bar" are fixed weights based on the 2008-2012 and 1973-2016 periods, respectively; "TV" indicates time-varying weights (5-years window). The dashed lines indicate the $95 \%$ confidence interval of the average currency misalignment, regardless of the weighting scheme. 